\title{
GLACIER CONTRIBUTION TO THE NORTH AND SOUTH SASKATCHEWAN RIVERS
}

\author{
A Thesis Submitted to the College of \\ Graduate Studies and Research \\ in Partial Fulfillment of the Requirements \\ for the Degree of \\ Master of Science \\ in the Department of Geography \\ (Centre for Hydrology) \\ University of Saskatchewan \\ Saskatoon
} By

\section{LAURA ELIZABETH LAMPLUGH COMEAU}

(C) Copyright Laura Elizabeth Lamplugh Comeau, December, 2008. All rights reserved 


\section{PERMISSION TO USE}

In presenting this thesis in partial fulfilment of the requirements for a Postgraduate degree from the University of Saskatchewan, I agree that the Libraries of this University may make it freely available for inspection. I further agree that permission for copying of this thesis in any manner, in whole or in part, for scholarly purposes may be granted by the professor or professors who supervised my thesis work or, in their absence, by the Head of the Department or the Dean of the College in which my thesis work was done. It is understood that any copying or publication or use of this thesis or parts thereof for financial gain shall not be allowed without my written permission. It is also understood that due recognition shall be given to me and to the University of Saskatchewan in any scholarly use which may be made of any material in my thesis.

Requests for permission to copy or to make other use of material in this thesis in whole or part should be addressed to:

Head of the Department of Geography

University of Saskatchewan

Saskatoon, Saskatchewan

S7N 5C8, Canada 


\begin{abstract}
The hydrological model WATFLOOD and a volume-area scaling relationship are applied to estimate glacier wastage and seasonal Melt contribution to the headwaters of the North and South Saskatchewan Rivers on the eastern slopes of the Canadian Rocky Mountains from 19751998. Wastage is defined as the annual volume of glacier ice melt that exceeds the annual volume of snow accumulation into the glacier system, causing an annual net loss of glacier volume. Melt is defined as the annual volume of glacier ice melt that is equal to, or less than, the annual volume of snow that does not melt from the glacier and instead accumulates into the glacier system. It is proposed that the distinction between these two components of glacier runoff is important in studies of the impact of glacier variations on flow. A comparison of similar glacierised and non-glacierised basin hydrographs shows that glacierised basins have greater specific streamflow in the late summer months of otherwise low flow, and the presence of glaciers in a basin results in a lower coefficient of variation of the July to September and annual streamflow as a result of the natural regulating impact of glaciers on streamflow. Glacier wastage and Melt are estimated from a hydrological-hypsometric comparison of glacierised and nonglacierised basins, mass balance data from Peyto Glacier and the published work of other researchers. The similarity of these results to those from the volume-area scaling approach indicates that this is a suitable method for estimating glacier wastage on a regional scale. Whilst the WATFLOOD results were similar to those from the hydrological-hypsometric approach regionally, there were considerable differences between the estimates of combined glacier wastage and Melt from different methods in the small, highly glacierised Peyto Glacier basin. The WATFLOOD results, and thus the estimates of Melt, are therefore treated with caution and it is proposed that glacier runoff data is collected with which to improve the model calibration,
\end{abstract}


verify results and make uncertainty estimations, currently prevented by the severe lack of data on glaciers in the North and South Saskatchewan River basins.

The results show that glacier wastage was smaller than Melt and varied between glaciers, though contributed over $10 \%$ to streamflow in a number of basins in the July to September period 1975-1998. Melt was positively correlated with basin glacier cover and contributed over $25 \%$ to streamflow from basins with glacier cover as little as $1 \%$ in the July to September period. The significance of Melt is manifest in its timing since it is equal to the annual volume of snow that accumulates into the glacier system, the volume of which melts as ice instead of snow thus entering the stream in the later summer months after snowmelt. Future glacier decline is therefore expected to result in an advancement of peak flow towards a snowmelt regime hydrograph, assuming that post glacial basin conditions do not similarly delay snowmelt runoff. The resulting reduced late summer flow, compounded by decreasing wastage contributions, is a concern for agricultural and industrial streamflow users, such as hydropower plants, and threatens ecological habitats. Downstream at Edmonton and Calgary, glacier wastage contributed approximately $3 \%$ of streamflow 1975-1998; however, Melt supplied over double this volume of flow thus the concern here is whether reservoir capacities are large enough to store a sufficient volume of the spring peak flow to meet supply needs in the late summer months of decreasing flows. 


\section{ACKNOWLEDGEMENTS}

I would like to extend my gratitude to my supervisor Dr. Dirk de Boer and advisory committee members Dr. Alain Pietroniro and Dr. John Pomeroy for their support and guidance throughout my Graduate Studies program. I would also like to thank my committee chair Dr. Xulin Guo for her administrative help and external examiner Dr. Amin Elshorbagy for his valuable suggestions.

I wish to thank Saul Marin for his invaluable help with the modelling work, and Dr. Julie Friddell for her essential administrative and friendly support. I also want to thank Mike Demuth and Pablo Dornes for their suggestions and involvement with the project, as well as Kelly Best,

Jessica Töyrä, Scott Munro and Brenda Toth for their help with field experience and equipment.

I would like to extend my thanks and appreciation to the following people for their encouragement, suggestions and friendship throughout my Graduate Studies program: Shawn Friess, Pat Lamont, Marissa Duncan, Krystine Lamotte, Chad Ellis, Alexis Poirier, Robin Morley, Gro Lilbæk and Matt MacDonald. In addition, special thanks to my parents Peter and Mart Comeau and sister Rachel, and to my family here in Canada, the Linsley's, who have supported me in so many ways and helped make living in a foreign country a very enjoyable experience.

The financial support provided by the following sources was greatly appreciated: The Canadian Foundation for Climate and Atmospheric Sciences (CFCAS) and IP3, and the department of Geography at the University of Saskatchewan. Thanks are also owed to the National Hydrology Research Centre, Saskatoon, for providing essential data for this research. 


\section{TABLE OF CONTENTS}

$\begin{array}{ll}\text { ABSTRACT } & \text { ii }\end{array}$

ACKNOWLEDGEMENTS

TABLE OF CONTENTS $\quad$ V

List of Tables viii

List of Figures $\quad$ X

1.0 Introduction, Definitions, Background and Objectives $\quad 1$

1.1 Introduction 1

1.2 Background: Glacier Dynamics and Mass Balance 3

1.3 Definition of Key Terms $\quad 5$

$\begin{array}{ll}1.4 \text { Purpose and Objectives } & 8\end{array}$

\begin{tabular}{ll} 
1.4.1 Purpose & 8 \\
\hline 1.4 .2 Objectives & 8
\end{tabular}

1.4.2 Objectives $\quad 8$

2.0 Literature Review 9

2.1 Past Climate Change and Glacier Variations 9

2.1.1 Climate change and glacier variations in the Rocky Mountains 9

2.1.2 Glacier variations in the North and South Saskatchewan River basins 11

2.1.3 Peyto Glacier 14

2.2 Future Climate Change and Potential Effects on Glaciers 16

2.2.1 Projected future climate change in the $\mathbf{N}$ and SSRB 16

$\begin{array}{ll}\text { 2.2.2 Effects of future climate change on glaciers } & 17\end{array}$

2.2.3 Projecting the rate of future glacier decline 18

2.3 Effect of Climate Change and Glacier Variations on Streamflow in the $\mathbf{N}$ and SSRB

2.3.1 Impacts of climate change on streamflow

2.3.2 Impacts of streamflow variability in the $\mathbf{N}$ and SSRB headwaters 21

2.3.3 Impacts of streamflow variability on the Canadian Prairies 22

$\begin{array}{ll}2.3 .4 \text { Glacial impact on streamflow } & 23\end{array}$

2.3.5 Glacial impact on streamflow in the N and SSRB 26

2.4 Estimating Glacier Contribution to Streamflow 28

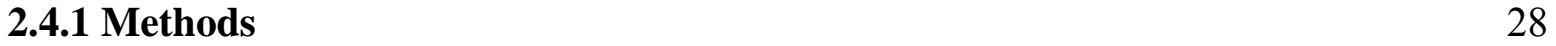

2.4.2 Glacier wastage $\quad 29$

2.4.3 Glacier wastage contribution to flow 30

2.4.4 Glacier wastage and Melt contribution to flow 34

2.5 Limitations and Gaps in Literature 38 
3.1 The North and South Saskatchewan River Basins 41

3.2 The $\mathbf{N}$ and SSRB Headwater Climate 43

3.3 Glacier Cover in the N and SSRB Headwaters 43

4.0 Methodology

4.1 Glacial Impact on Streamflow in the N and SSRB Headwaters 51

4.2 Hydrological Model WATFLOOD $\quad 52$

4.2.1 Description of the hydrologic model $\quad 53$

4.2.1.1 Processes within WATFLOOD

4.2.1.2 Modelling glacier runoff $\quad 57$

4.2.1.3 Modelling glacier runoff in WATFLOOD 59

4.2.1.4 Routing glacier runoff $\quad 62$

4.2.2 Setting up the WATFLOOD model for the North and South Saskatchewan River $\begin{array}{ll}\text { basins } & 63\end{array}$

4.2.2.1 Generating the WATFLOOD physiographic files 63

$\begin{array}{ll}\text { 4.2.2.2 Land cover } & 68\end{array}$

4.2.2.3 Hydrometric data 68

$\begin{array}{ll}\text { 4.2.2.4 Meteorological data } & 69\end{array}$

4.2.2.5 Precipitation $\quad 69$

$\begin{array}{ll}\text { 4.2.2.6 Temperature } & 71\end{array}$

4.2.3 Initial calibration, parameter estimation and sensitivity analysis of WATFLOOD

4.3 Modelling Glacier Wastage and Melt with WATFLOOD 75

$\begin{array}{ll}\text { 4.3.1 Model evaluation } & 77\end{array}$

4.3.2 Estimating glacier wastage and Melt contribution 78

4.3.3 Limitations of estimating glacial impact on streamflow with WATFLOOD 80

4.4 Glacier Wastage and Melt from a Hydrological-hypsometric Comparison $\quad 83$

$\begin{array}{ll}\text { 4.4.1 Method } & 83\end{array}$

$\begin{array}{ll}\text { 4.4.2 Limitations } & 92\end{array}$

4.5 Glacier Wastage from Ice Volume Estimation and Change 94

4.6 Comparison of Glacier Wastage and Melt Results 99

4.7 Calculating Melt $\quad 99$

4.8 Glacier Wastage and Melt Contribution to Peyto Glacier Basin 100

4.8.1 Modelling Peyto Glacier basin streamflow with WATFLOOD 101

$\begin{array}{ll}\text { 4.8.2 Hydrological-hypsometric approach } & 102\end{array}$

4.8.3 Volume- area relationship 103

$\begin{array}{ll}\text { 4.8.4 Mass balance data } & 103\end{array}$

4.9 Glacier Contribution at Edmonton and Calgary Downstream 105

$\begin{array}{ll}\text { 5.0 Results and Analysis } & 108\end{array}$

5.1 Glacial Impact on Streamflow in the $\mathbf{N}$ and SSRB Headwaters 108 
5.1.1 Observed streamflow hydrograph analysis

5.1.2 Streamflow coefficient of variation 112

$\begin{array}{ll}\text { 5.2 Climate Variations from 1975-1998 } & 114\end{array}$

5.3 Modelling Glacier Wastage and Melt with WATFLOOD 118

$\begin{array}{ll}\text { 5.3.1 Results of the Nash Sutcliffe analysis } & 119\end{array}$

5.3.2 Results of the Mean Bias Differences (MBD) analysis 119

5.3.3 Observations of the observed and WATFLOOD simulated hydrographs 120

$\begin{array}{ll}\text { 5.3.4 Modelled glacier wastage and seasonal Melt contribution } & 122\end{array}$

5.4 Glacier Wastage and Melt from a Hydrological-hypsometric Comparison 127

5.5 Glacier Wastage from Ice Volume Estimation and Change 135

5.6 Comparison of Glacier Wastage and Melt results 140

5.6.1 Comparison of WATFLOOD and hydrological-hypsometric approaches 140

5.6.2 Calculation of Melt 143

5.7 Glacier Wastage and Melt in Peyto Glacier Basin 145

$\begin{array}{ll}\text { 5.7.1 WATFLOOD results } & 146\end{array}$

$\begin{array}{ll}\text { 5.7.2 Hydrological-hypsometric comparison results } & 147\end{array}$

$\begin{array}{ll}\text { 5.7.3 Volume-Area relationship } & 148\end{array}$

$\begin{array}{ll}\text { 5.7.4 Mass balance data } & 148\end{array}$

$\begin{array}{ll}\text { 5.7.5 Previous research } & 149\end{array}$

$\begin{array}{lr}\text { 5.7.6 Comparison of results } & 150\end{array}$

5.7.7 Review of Young's (1982) research 151

5.7.8 Comparison of annual results 154

$\begin{array}{ll}\text { 5.8 Glacier Contribution Downstream } & 160\end{array}$

$\begin{array}{ll}\text { 6.0 Discussion } & 162\end{array}$

6.1 Glacial Impact on Streamflow in the N and SSRB Headwaters 162

6.2 Glacier Wastage and Seasonal Melt Contributions 164

6.2.1 WATFLOOD modelled contribution 164

6.2.2 Hydrological-hypsometric comparison 165

6.3 Glacier Wastage Contribution to Flow 166

6.4 Implications of the Differences between Glacier Wastage and Melt 169

6.5 Peyto Glacier Basin Glacier Runoff 170

6.6 Glacier Contribution at Edmonton and Calgary 173

$\begin{array}{ll}\text { 7.0 Conclusions } & 176\end{array}$

$\begin{array}{ll}\text { List of References } & 181\end{array}$

$\begin{array}{ll}\text { APPENDIX A } & 208\end{array}$

$\begin{array}{ll}\text { APPENDIX B } & 214\end{array}$ 


\section{List of Tables}

\section{Table}

Page

Table 3.1 Gauging station information and area-wise changes in the extent of glacier cover for subbasins of the NSRB headwaters (less Brazeau basin). ...................................................... 48 Table 3.2 Gauging station information and area-wise changes in the extent of glacier cover for subbasins of the SSRB headwaters (less Oldman basin). 49

Table 4.1 Equations used to represent the processes in WATFLOOD. 55 Table 4.2 Basins modelled in the N and SSRB headwaters, including cumulative drainage area and percentage basin glacier cover. 75 Table 4.3 N and SSR headwater basins compared, with their area, common period of flow record, and hypsometric attributes. 86 Table 5.1 Mean observed monthly flow as a percentage of the total June to October flow volume, and $C V$ for mean annual and July to September flows from 1976-1992.... 109

Table 5.2 Differences between climate variables averaged for the winter and summer months between 1970-1980 and 1993-2003, as an average of the Banff, Lake Louise and Jasper meteorological station data

Table 5.3 Results of Nash-Sutcliffe model efficiency $\left(\mathrm{R}^{2}\right)$ and Mean Bias Differences (MBD) analysis for modelled basins of the $\mathrm{N}$ and SSRB.

Table 5.4 Modelled percentage combined glacier wastage and Melt contribution to July to September streamflow for basins of the N and SSRB.

Table 5.5 Compared sub-basins of the N and SSRB with their glacier cover in 1975 and 1998, coefficient of variation and mean streamflow from July-September with corresponding percentage glacier contribution for 1970-1980 and 1993-2003 (where possible). 128 Table 5.6 Total glacier ice volume and ice volume change from 1975-1998 in the headwaters of the $\mathrm{N}$ and SSRB.

Table 5.7 Glacier volume change (net wastage) as a percentage of observed streamflow, annually and in the July to September period.

Table 5.8 Glacierised basins and their estimated July to September combined glacier wastage and Melt contribution by WATFLOOD (WAT) and the hydrological-hypsometric $(\mathrm{H}-\mathrm{H})$ basin comparison.

Table 5.9 Difference between combined glacier wastage and Melt (WATFLOOD) and glacier wastage (volume-area) as an estimation of Melt percentage seasonal contribution to streamflow from $1975-1998$ in $\times 10^{6} \mathrm{~m}^{3}$.

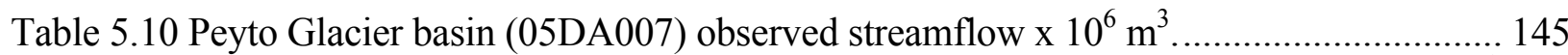
Table 5.11 Monthly combined glacier wastage and Melt runoff from Peyto Glacier basin x $10^{6} \mathrm{~m}^{3}$ from 1973-1977 modelled by WATFLOOD ............................................................. 147 Table 5.12 Monthly combined glacier wastage and Melt runoff from Peyto Glacier basin x $10^{6} \mathrm{~m}^{3}$ from 1971-1977 estimated by the hydrological-hypsometric method ...................................... 147 Table 5.13 Mass balance of Peyto Glacier 1967-1977 x 106 $\mathrm{m}^{3}$ water equivalent (w.e.)............. 148 Table 5.14 Summary of annual average glacier contribution to streamflow for Peyto Glacier basin estimated by different methods, $x 10^{6} \mathrm{~m}^{3}$ water equivalent................................................... 149 Table 5.15 Analysis of glacier runoff calculated by Young (1982), units are x $10^{6} \mathrm{~m}^{3}$ water equivalent. 
Table 5.16 Combined glacier wastage and Melt from Peyto Glacier basin x $10^{6} \mathrm{~m}^{3}$ water equivalent, calculated from three different methods and expressed as a percentage of the observed streamflow.

Table 5.17 Combined glacier wastage and Melt from Peyto Glacier basin estimated using WATFLOOD and the summer mass balance data below the ELA, $x 10^{6} \mathrm{~m}^{3}$ water equivalent.... 157 Table 5.18 Glacier wastage and Melt percentage contribution to Peyto Glacier basin streamflow from July to September, $\mathrm{x} 10^{6} \mathrm{~m}^{3}$ water equivalent, using both WATFLOOD (WAT) and summer mass balance (S-mb) below the ELA data. 160

Table 5.19 Glacier wastage and seasonal Melt contribution to streamflow at Edmonton and Calgary from $1975-1998$, x $10^{6} \mathrm{~m}^{3}$ water equivalent. 161 


\section{List of Figures}

Figure

Page

Figure 1.1 a) First documented photograph of Peyto Glacier in 1896 (W.D.Wilcox) and in 2008 (L.E.L.Comeau) b) Peyto Glacier in 1966 (photograph by W.E.S Henoch) and in 2001

(photograph M.N Demuth) with the neo-glacial maximum indicated..................................... 15

Figure 3.1 The North and South Saskatchewan River basins and headwater sub-basins............ 42

Figure 3.3 Glacier cover in the SSRB (1975 and 1998) (less Oldman basin)......................... 46

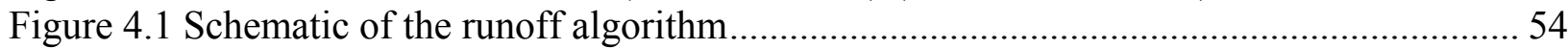

Figure 4.2 Schematic of the GRU approach and routing scheme........................................ 57

Figure 4.3 Completed EnSim watershed object in 2D showing the modelled basins in the NSRB

(brown) and SSRB (grey) headwaters, and DEM elevation..... 64

Figure 4.4 Adjacent cells with boundary flow in different directions ...................................... 65

Figure 4.5 WATFLOOD map file for the a) North and b) South Saskatchewan headwater basins

displayed with EnSim Hydrologic,

Figure 4.6 Locations of the meteorological stations in relation to the a) NSRB and b) SSRB headwater regions. 69

Figure 4.7 Basins modelled in the $\mathrm{N}$ and SSRB headwaters, underlain with $50 \mathrm{~m}$ DEM.......... 76

Figure $4.8 \mathrm{~N}$ and SSR headwater basins compared to estimate combined glacier wastage and

Melt contribution to flow.

Figure 4.9 Hypsometric curves for the compared glacierised and non-glacierised basins.

Percentage basin glacier cover is shown in parenthesis as an average of the 1975 and 1998 glacier cover.

Figure 4.10 Observed streamflow hydrographs for the compared glacierised and non-glacierised

basins for the 1975 and 1998 periods.

Figure 5.1 Monthly observed streamflow as a percentage of the June to October streamflow for basins of differing glacier covers. Percentage basin glacier cover is given in parenthesis. 110 Figure 5.2 Variation of observed streamflow coefficient of variation, a) annual b) July to September, with percentage basin glacier cover for N and SSRB headwater basins from 19761992.

Figure 5.3 Monthly climate data for 1970-1980 and 1993-2003 as an average of the climate data recorded at Lake Louise, Jasper and Banff, for a) mean temperature b) snowfall and c) rainfall.

Figure 5.4 WATFLOOD simulated (with and without glaciers at the 1998 cover) and observed streamflow for the North Saskatchewan River at Whirlpool and the Bow River at Banff from 1993-2003

Figure 5.5 Relationship between modelled percentage July to September combined glacier wastage and Melt contribution to streamflow and percentage basin glacier cover 126 Figure 5.6 Percentage increase in the specific runoff for glacierised basins compared to similar non-glacierised basins. Between parenthesis is the percentage glacier cover (1975). 129 Figure 5.7 Relationship between percentage combined glacier wastage and Melt contribution to streamflow from the hydrological-hypsometric approach and percentage basin glacier cover.. 131 Figure 5.8 Relationship between percentage glacier wastage contribution to streamflow and percentage basin glacier cover, annually and in the July to September period from 1975-1998 138 
Figure 5.10 Relationship between percentage basin glacier cover and average percentage Melt contribution to July to September streamflow 1975-1998. Basin glacier cover is the average of the 1975 and 1998 glacier cover.

Figure 5.11 Peyto Glacier basin WATFLOOD simulated (with and without glaciers) and observed streamflow from 1973-1978 146 


\section{Chapter 1}

\subsection{Introduction, Definitions, Background and Objectives}

\subsection{Introduction}

Loss of glacier volume worldwide has been generally continuous since the $19^{\text {th }}$ century, with the rate of loss accelerating over the last forty years (Dyurgerov and Meier 2000). This acceleration is consistent with increasing global mean temperatures, mainly attributed to the rising levels of atmospheric greenhouse gases (Kargel et al. 2005). Whilst there has been considerable spatial variability, shifts have been identified in the net mass balance time series such as that occurring in the mid 1970s towards increasingly negative net balances (losses of glacier volume) associated with a shift in the climate towards warmer temperatures (Meier et al. 2003). With the continued emission of greenhouse gases, projected associated rise in global mean temperatures and uncertain precipitation projections, the majority of glaciers worldwide are expected to continue to decline, posing a potential long-term problem for the populations that depend on the freshwater rivers and lakes they supply. The sources of water to such rivers and lakes are rainfall and snowfall, with glaciers acting as a dynamic storage system storing water in the form of ice. The impact a glacier in equilibrium (neither advancing nor declining) has on streamflow water supply is seasonal since the glacier effectively delays a portion of the snowmelt runoff by accumulating snowfall into the glacier system, and replacing the equivalent runoff volume with ice ablation runoff occurring in the late summer months after the snowmelt peak. A glacier in decline as a result of increased ablation and/or decreased snowfall may cause a short term increase in streamflow volume due to glacier wastage contributions (volume of annual 
net ice loss). In the long-term, however, continued glacier decline will result in diminished wastage contributions and a reduction in the volume of ice stored in the glacier to release as runoff in the late summer months. Approximately one sixth of the earth's population relies on snow and ice melt for their provision of water (Hock et al. 2006). Despite potential short term increases in streamflow water supply from glacier wastage contributions, long term glacier decline raises concerns over seasonal water availability for these populations in the late summer months of otherwise low flows.

The North and South Saskatchewan Rivers originate in both glacierised and nonglacierised headwater basins on the eastern slopes of the Canadian Rocky Mountains, and provide a fresh water supply to a variety of users in both the mountainous and foothill regions and the Prairies Provinces through which they flow towards Hudson Bay. The Prairies rely heavily on this fresh water supply for uses such as irrigation in the summer growing season, especially since they are prone to hydrological extremes, particularly droughts (Töyrä et al. 2005). Approximately $90 \%$ of the flow in the North and South Saskatchewan Rivers originates in the Rocky Mountains (SSRB 2007), and with the general increasingly negative glacier mass balance trend projected to continue into the future it is important that these rivers and the glaciers in their headwaters are studied to determine the impacts of glacier decline in conjunction with projected climate change. 


\subsection{Background: Glacier Dynamics and Mass Balance}

A glacier forms when the accumulation of ice (derived from compacted metamorphosed snow as a result of annual snow prevalence) exceeds its loss over a time span longer than a few years (Kaser 2006). A glacier is a dynamic system which can be divided into two zones, the upper accumulation zone where annual accumulation exceeds losses by ablation, and the lower ablation zone where annual ablation exceeds accumulation. Snow and ice transfers from the accumulation zone to the ablation zone by glacier flow, which takes place by sliding, deformation of the ice, and deformation of the glacier bed (Benn and Evans 1998). When a glacier is in equilibrium, the rates of glacier flow match the rates at which snow and ice are added in the accumulation zone and lost from the ablation zone. The accumulation and ablation zones are separated by the equilibrium line, where annual accumulation and ablation are equal, and the equilibrium line altitude (ELA) is determined by local and regional climate and topography (Benn and Evans 1998). Glacier mass balance is defined as the difference between glacier gains and losses (expressed in water equivalent) measured over a specific time period, usually a year, with annual net balance $\left(b_{n}\right)$ being the sum of the gross amount of accumulation (winter balance $b_{w}$ ) and gross amount of ablation (summer balance $b_{s}$ ) on the glacier (Benn and Evans 1998):

$$
b_{n}=b_{w}+b_{s}
$$

The winter mass balance $\left(b_{w}\right)$ accumulation inputs are derived from precipitation, drifting, condensation and avalanching. The summer mass balance $\left(b_{s}\right)$ ablation is the result of snowmelt, evaporation and sublimation, calving (blocks of ice breaking away from the glacier snout), base melting (when the base of the glacier is at the pressure melting point and ice melts as the result of frictional heating associated with the glacier sliding over its bed), and surface 
melting which is controlled by the available energy (Hooke 2005). Seasonal balance surveys usually conducted by point measurements of a network of stakes drilled into the glacier ice are generally completed in April or May (measuring snow depth accumulation to determine $b_{w}$ ) and September or October (measuring loss of snow and ice depth to determine $b_{s}$ ) in northern midlatitudes. Glacier mass balance is a good indicator of climate fluctuation. The net mass balance integrated over the glacier (a measure of change in glacier volume) in the short term responds with little delay to climate change with about a one year lag. Annual changes in volume therefore can be considered almost simultaneous with changes in weather (Dyurgerov and Meier 2000). The one year lag is expected because the albedo effect of a non-zero balance year may have some carryover effect to the next year (Dyurgerov and Meier 2000). Albedo is defined as the ratio of short wave radiation reflected from a surface to the total short wave radiation falling on that surface (Meier 1969). Thus, since glacier ice has a lower albedo than snow, less light is reflected and there is more energy available to melt the surface. In addition, the dimensions (e.g. area and length) of a glacier at any one time reflect the dynamic adjustment to a cumulative mass balance history ranging from a few years to a several decades (Demuth and Keller 2006). Glaciers therefore are important for reconstructing past climate variations (Dyurgerov and Meier 2000). 


\subsection{Definition of Key Terms}

Arising from this study, it is determined that there are two components of glacier runoff: i) Glacier wastage and ii) Melt. It is necessary that they are treated as separate entities and that it is clearly stated which, if not both, are being calculated prior to any investigation into glacier runoff. For clarity throughout this thesis, both components are defined below with reference to a glacier year, which generally begins and ends in late September in northern mid-latitudes thus including an ablation and accumulation season. Each term in the equations and explanations below are with reference to water equivalent volumes.

Glacier mass balance for a glacier year $d m / d t$ can be defined in terms of the inputs and outputs to the glacier system:

$$
d m / d t=P_{s}-M_{s}-M_{i}-S-R
$$

Where:

$P_{s}=$ Snow precipitation

$M_{\mathrm{S}}=$ Snowmelt

$M_{i}=$ Ice melt

$S=$ Sublimation

$R=$ Losses and/or gains due to avalanching, snow-drifting and ice calving

To simplify this equation, thus treating sublimation as negligible and assuming no snow inputs from avalanching and snow-drifting or blowing snow and no ice losses from calving, $S$ and $R$ are removed to give: 


$$
d m / d t=P_{s}-M_{s}-M_{i}
$$

In a glacier year, not all the snow that falls on the glacier $\left(P_{s}\right)$ melts off the glacier, since in the accumulation zone the annual accumulation is greater than the annual ablation. The snow that remains on the glacier $\left(P_{s}-M_{s}\right)$ enters the glacial system as it will be compacted and metamorphosed into firn, and eventually ice following burial under subsequent snowfall, assuming it does not melt in the ablation season of the following year. If a glacier is in equilibrium, such that the annual accumulation (or winter balance $b_{w}$ ) equals the annual ablation (or summer balance $b_{s}$ ) and $d m / d t$ (or the net balance $b_{n}$ ) equals zero, then:

$$
M_{i}=P_{s}-M_{s} \quad \text { when } d m / d t=0
$$

This ice melt $\left(M_{i}\right)$, which is the annual glacier ice melt that is equal to the annual volume of snow that accumulates into the glacier system $\left(P_{s}-M_{s}\right)$ is termed Melt. If a glacier mass balance is positive, such that annual accumulation $\left(b_{w}\right)$ is greater than annual ablation $\left(b_{s}\right)$ and, $d m / d t$ is greater than zero, then:

$$
M_{i}<P_{s}-M_{s} \quad \text { when } d m / d t>0
$$

Where $M_{i}$ is the annual glacier ice melt that is less than the annual snow accumulation into the glacier system $\left(P_{s}-M_{s}\right)$. Melt is therefore defined as the water equivalent annual volume of glacier ice melt that is equal to, or less than, the water equivalent annual volume of snow that does not melt from the glacier and instead accumulates into the glacier system. 
If a glacier mass balance is negative, such that annual accumulation $\left(b_{w}\right)$ is less than annual ablation $\left(b_{s}\right)$, and $d m / d t$ is less than zero, then:

$$
M_{i}>P_{s}-M_{s} \quad \text { when } d m / d t<0
$$

Where $M_{i}$ consists of two components, annual ice melt that is equal to the annual snow accumulation into the glacier system $\left(P_{s}-M_{s}\right)$ termed Melt, and also the residual annual ice melt that causes a negative net mass balance, termed wastage. Wastage is therefore defined as the water equivalent annual volume of ice melt that exceeds the water equivalent annual volume of snow accumulation into the glacier system, causing an annual net loss of glacier volume. Therefore, in a year of negative glacier mass balance:

$$
M_{i}=\text { Wastage }+P_{s}-M_{s} \quad \text { when } d m / d t<0
$$

and $\quad$ Melt $=P_{s}-M_{s}$

On an annual time scale, therefore, the presence of a glacier in a basin impacts total streamflow volume only in terms of wastage contributions. The significance of Melt is manifest in its timing, with the glacier effectively delaying runoff from May and June as a result of reduced snowmelt from the ice surface relative to the surrounding rock. The snow instead accumulates into the glacier system $\left(P_{s}-M_{s}\right)$, and runoff is delayed to July to September when the majority of ice melt occurs. It is important to understand that glacier contribution to 
streamflow in terms of Melt is only significant on a seasonal time scale, not in terms of increased total annual streamflow volume from the glacier basin.

\subsection{Purpose and Objectives}

\subsubsection{Purpose}

The purpose of this research is to estimate and assess the impacts of glacier wastage and seasonal Melt runoff on the North and South Saskatchewan Rivers, and thus determine whether future glacier decline will have a significant impact on streamflow.

\subsubsection{Objectives}

The first objective is to asses the impact of the presence of glaciers on streamflow in the North and South Saskatchewan River headwater basins. The second objective is to estimate the percentage contribution of glacier wastage and seasonal Melt to streamflow for the larger North and South Saskatchewan River basins and major sub-basins. Thirdly, the calculated glacier wastage and Melt from a small scale glacierised basin will be compared to mass balance data and findings from previous research to verify the methods used regionally. This will enable the determination of whether continued future glacier decline will have a significant impact on streamflow. 


\section{Chapter 2}

\subsection{Literature Review}

\subsection{Past Climate Change and Glacier Variations}

\subsubsection{Climate change and glacier variations in the Rocky Mountains}

Glaciers in the Canadian Rocky Mountains have been in general decline since the neoglacial maximum around 1850. During this period there is evidence of marked regime shifts towards lower winter balance (Watson and Luckman 2005) with the most recent episode beginning in the mid 1970s and playing a major role in fuelling the consistent negative net mass balance trend in the decades following (Demuth and Keller 2006).

Both local and regional climate variables affect glacier mass balance. The meteorological stations with the longest climate records, most useful for long term trend analysis, are unfortunately those at lower elevations. Temperature and precipitation records from Banff, Lake Louise, Jasper, Golden and Valemount climate stations with elevations ranging from 750-1540 m.a.s.1. have, however, been combined in order to analyse long term climate trends in the Canadian Rockies (Luckman 1998). This climate record analysis shows that mean annual temperatures have risen approximately $1.4^{\circ} \mathrm{C}$ over the last 100 years, with the greatest increase in winter temperatures (about $3.2^{\circ} \mathrm{C}$ per century) and spring and summer temperatures showing smaller positive trends (about $1.3^{\circ} \mathrm{C}$ per century) (Luckman 1998). Precipitation records show variable patterns, though higher levels were generally found in the mid-20 $0^{\text {th }}$ century (Luckman 1998). An examination of the proxy record from tree rings, indicates that summer and spring 
temperatures in the last half of the $20^{\text {th }}$ century are higher than during any equivalent periods in the last 900 years, and there is some evidence to suggest that glaciers are smaller now than at any time in the last 3000 years which raises concerns over the impacts that may result from a continuation of these trends (Luckman 1998).

Relations between atmospheric circulation regimes and glacier variations have been the subject of research of a number of studies that have found significant correlations between shifts in these regimes and the spatial and temporal variability of snow cover and glacier mass balance (e.g. McCabe et al. 2000, Stahl et al. 2006, Shea and Marshall 2007). Global atmospheric circulation can be described by negative and positive anomalies of atmospheric pressure which extend across several hundreds to thousands of kilometres, and variations in these pressure anomalies correlate with fluctuations in surface temperature and precipitation (McCabe et al. 2000). Such variations in the Canadian Cordillera region, namely anomalies in the Pacific Ocean sea surface temperatures (SSTs) resulting from regime shifts in the Pacific Decadal Oscillation (PDO) and its relationship with the Pacific North American Pattern (PNA), as well as influences of the El Niño-Southern Oscillation (ENSO) (e.g. Lafrenière and Sharp 2003), influenced a shift in the mid-1970s towards an increase in average winter temperatures and reduced frequency of snow producing weather types, corresponding to the shift towards negative mass balance trends (Bitz and Batistti 1999, Hodge et al. 1998, Demuth and Keller 2006, Stahl et al. 2006, Shea and Marshall 2007, Demuth et al. 2008). This PDO warm phase (beginning specifically in 1976) seems to manifest the meridional flow of dryer air into the Cordillera in winter, and the PNA pattern is intensified correspondingly with the position and strength of the Aleutian low promoting warm, south westerly flows over the north western Pacific. Storm tracks are generally biased northwards therefore causing a lack of moisture in the southern Cordillera and western 
Prairies (Moore and Demuth 2001, Demuth et al. 2008). A resulting general increase in altitude of the snow-line, and increased rate of snow-line retreat in the summer, exposes a greater area of lower-albedo glacier ice earlier in the summer, thus increasing summer ablation on the glacier.

\subsubsection{Glacier variations in the North and South Saskatchewan River basins}

DeBeer and Sharp (2007) studied the changes in glacier area and volume within the southern Canadian Cordillera including areas of the Rocky, Columbia and Coast Mountains from 1951/52 aerial photography to 2001/02 Landsat 7ETM+ images applying a volume-area scaling relationship (Chen and Ohmura 1990a, Bahr et al. 1997) to determine volume change. They found that total ice area decreased by $5.2 \%$, with the greatest loss observed of $15 \%$ or $6 \mathrm{~km}^{2}$ in the 59 southern Rocky Mountain glaciers studied. The pattern of change relative to initial glacier area showed considerable scatter indicating that local factors are important in determining glacier variations. For the southern Rocky Mountains, volume loss of the glaciers studied was $0.3 \mathrm{~km}^{3}$ equating to $21 \%$ loss relative to initial volume. In all regions, they concluded that the smallest glaciers $\left(<0.1 \mathrm{~km}^{2}\right)$ lost less percentage volume and area, increasing to greatest percentage loss observed for the largest glaciers ( $>20 \mathrm{~km}^{2}$ in the Coast Mountains). The larger glaciers accounted for the majority of total area and wastage loss in each region, and thus are determined to be much more important than the smaller glaciers in terms of the collective amount of ice they contain and thus wastage produced. Whilst this is likely to be true in terms of total wastage contributions, the finding that larger glaciers lost the greatest percentage area is contrary to other studies, which found that smaller glaciers experienced the largest fractional area change in areas of the Swiss Alps, Canadian Artic and North Cascades, USA (Sharp et al. 2003, Paul et al. 2004, Granshaw and Fountain 2006). 
The most recent and more comprehensive study of glacier area in the Rocky Mountains by Demuth et al. (2008) examines glacier area loss for the North and South Saskatchewan River basin headwaters (N and SSRB) from 1975-1998, a small portion of which in the SSRB was studied by DeBeer and Sharp (2007). Demuth et al. (2008) conclude that the smallest glaciers (< $0.1 \mathrm{~km}^{2}$ ) experienced the greatest percentage area change, with many of these glaciers disappearing in the time period, with the fractional area change decreasing towards the largest area glaciers $\left(>10 \mathrm{~km}^{2}\right)$ which experienced the smallest relative change. Demuth et al. (2008) support the assertion by Granshaw and Fountain (2006) that smaller glaciers are most likely to shrink faster due to their larger area-to-volume ratio. Demuth et al. (2008) observe that smaller glaciers experienced an accelerated rate of diminution and suggest that glaciers smaller than 1-2 $\mathrm{km}^{2}$ begin to be overwhelmed by a perimeter-area effect and become more susceptible to energy inputs from surrounding areas.

Demuth et al. (2008) also note considerable variability in relative glacier area change with relation to glacier size, especially for glaciers less than $1 \mathrm{~km}^{2}$ for which the variability overwhelms the differences between the smaller classes. In agreement with DeBeer and Sharp (2007), they suggest that this is due to the control exerted by the geological setting of the glacier on local climate, such as glaciers positioned so they are susceptible to avalanching and wind blown snow resulting in a relative immunity to climate change (Kuhn 1993). Demuth et al. (2008) also note that numerous small glaciers in their study area are situated at relatively high elevations so that they are less susceptible to the effects of solar radiation. This supports DeBeer and Sharp's (2007) suggestion that their large glaciers experience greater fractional area change because they tend to occupy a greater elevation interval, and thus larger change may be the result of relatively more area having once extended to lower elevations. 
In explanation of the contrast in results, Demuth et al. (2008) suggest that DeBeer and Sharp (2007) found larger glaciers to exhibit greater relative area change due to the circumstance that the smaller glaciers in their selection have reached a size/situation threshold so that they are overwhelmingly controlled by local factors. Indeed, Demuth et al. (2008) observe that the Southern Rocky Mountain region glaciers analysed by DeBeer and Sharp (2007) totalled 59 of the approximate 200 that are noted in the Glacier Atlas of Canada to have existed within the limits of their region in the mid $20^{\text {th }}$ century. Also, the total number of glaciers in the SSRB headwaters, as studied by Demuth et al.(2008), totalled 369 in 1975, decreasing to 291 in 1998, so that the differing conclusions may be a result of the smaller sample chosen by DeBeer and Sharp (2007). In addition, the glaciers of the SSRB (Demuth et al. 2008) showed considerable fragmentation, and 181 glaciers were observed to disappear from 1975-1998, with a total area loss of $23 \%$, whereas of the glaciers studied by DeBeer and Sharp (2007) only one was observed to disappear completely and the total area loss determined to be $15 \%$, which is unexpectedly lower since their study period was over a longer time frame (1951/2-2001/2).

Therefore when assessing the area change of glaciers in any region, care should be taken over selecting a sample of glaciers, and acknowledgement of local factors that may affect the response of theses glaciers to regional climate change should be given. Also, the relative number of glaciers of each size in the sample chosen needs to be taken into consideration, and it is possible that larger glaciers are still responding to previous hydrologically significant climate variation (Demuth et al. 2008). From this review of glacier area change in the Rocky Mountains, it appears that the conclusions of Demuth et al. (2008) are more likely to be accurate (assuming accurate glacier delineation from remotely sensed images) since every glacier in the majority of headwater basins in the N and SSRB is included in the assessment of area and volume change 
(with the exception of the Brazeau and Oldman River basins respectively), so that the dangers of selecting a misrepresentative sample are avoided.

\subsubsection{Peyto Glacier}

Demuth and Keller (2006) investigated the influence of climate variability from 19661995 on the mass balance of Peyto Glacier, which is located in the headwaters of the North Saskatchewan River basin (NSRB) on the eastern slopes of the Rocky Mountains adjacent to the continental divide. The results of this study are similar to the general observations of the regions glaciers in that since the mid-1970s there has been a continuous series of negative mass balances. Winter balance was found to play a dominant role in influencing the net mass balance, with a marked shift to a lower winter balance in 1976, and further attenuation of a lower than average winter balance in the late 1980s and also more recently, a negative trend which is expected to continue (Demuth and Keller 2006). The summer balance is also important since it either reinforces or compensates for the lower than average winter balance, and there is evidence of above average summer balance in the late 1970s to early 1980s, and again more recently (Demuth and Keller 2006). These shifts and trends in the mass balance correspond to climate variations from regime shifts in the ocean-atmosphere circulation patterns, and the rate of mass loss shows signs of recent acceleration broadly consistent with estimated anthropogenic radiative forcing (Demuth and Keller 2006). Indeed, Demuth and Keller (2006) determine from volume changes estimated by Holdsworth et al. (2006) from 1966-1984, Wallace (1995) from 18961966, and their own mass balance data that Peyto Glacier has lost $70 \%$ of its volume since the first documented photograph taken in 1896 by Wilcox. This photograph can be compared to the most recent 2008 photograph by Comeau from a similar view point in which the glacier snout is 
no longer visible (Figure 1.1a). The extent of glacier area variation between 1966 and 2001 is shown in Figure 1.1b, with the neo-glacial maximum (circa 1840) also indicated. This raises the question of how the changing future climate will affect glacier variations and whether these dramatic declining glacier trends will continue, potentially affecting water supplies from glacierised basins in the $\mathrm{N}$ and SSRB.
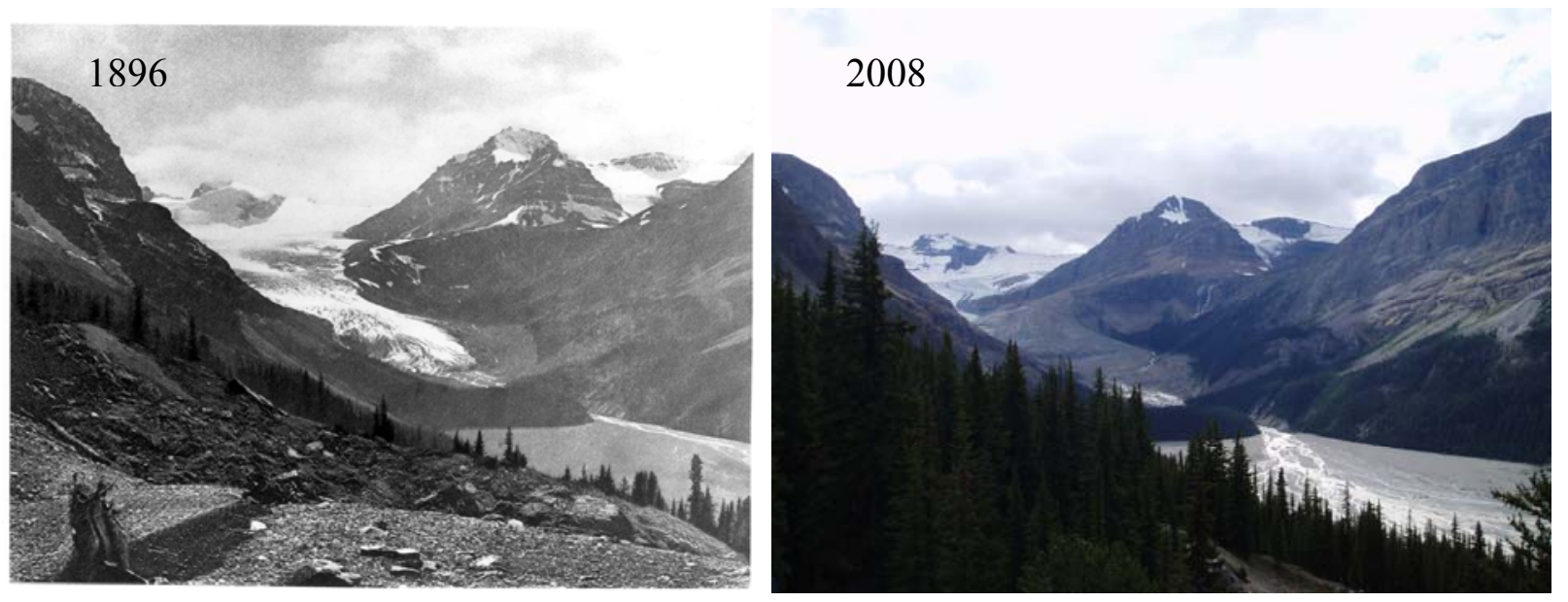

a)
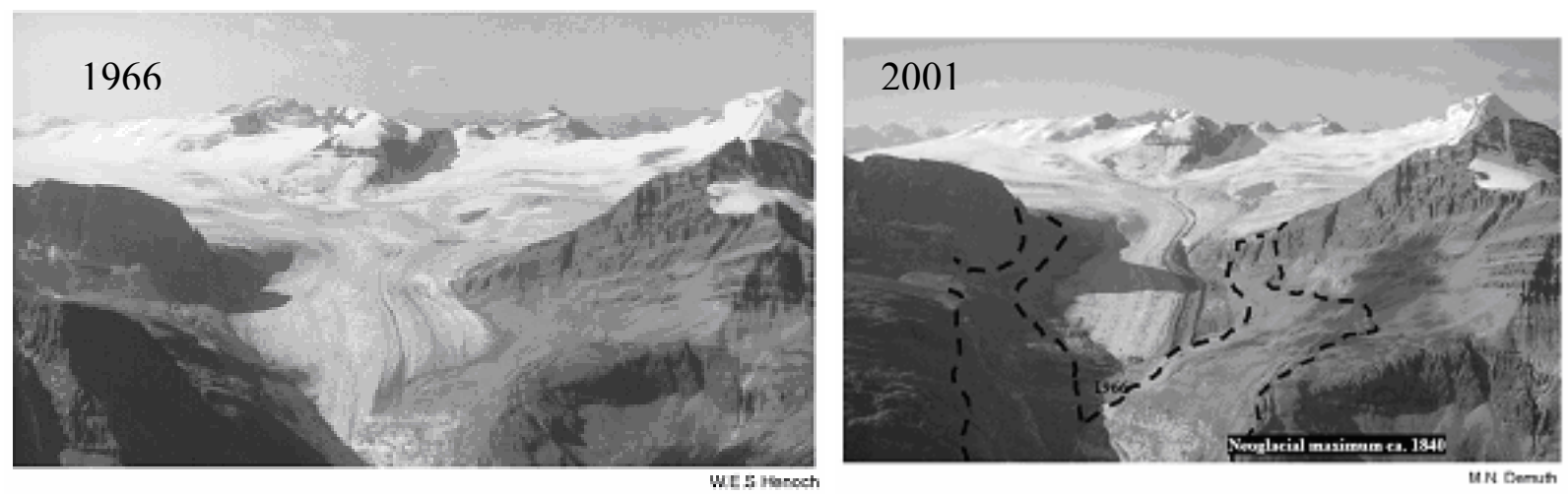

b)

Figure 1.1 a) First documented photograph of Peyto Glacier in 1896 (W.D.Wilcox) and in 2008 (L.E.L.Comeau) b) Peyto Glacier in 1966 (photograph by W.E.S Henoch) and in 2001 (photograph M.N Demuth) with the neo-glacial maximum indicated.

Credit for Wilcox photograph: Whyte Museum of the Canadian Rockies, Photograph by Walter D. Wilcox, NA 66561. Source: Demuth and Pietroniro 2003. 


\subsection{Future Climate Change and Potential Effects on Glaciers}

\subsubsection{Projected future climate change in the $\mathrm{N}$ and SSRB}

An evaluation of the ability of eleven global climate models (GCMs) to predict future climate change on the Canadian Prairies based on their performance of simulating current conditions (1961-1990) found considerable variation and difficulty in modelling precipitation, though mean temperature magnitudes and spatial patterns were reasonably well simulated (Töyrä et al. 2005). Based on the median of the three GCMs, ECHAM4, HadCM3 and NCAR-PCM, that could best simulate current climate conditions from 1961 to 1990, Töyrä et al. (2005) projected temperature and precipitation using scenarios A2 and B2 from the Special Report on Emissions Scenarios (SRES). Both scenarios focus on regional solutions, as opposed to global, with A2 projecting higher cumulative emissions between 1990 and 2100, and B2 projecting that emissions level off with time. The range of mean temperature and total precipitation change for the 2050 and 2080 centered timelines as projected by these models and scenarios for the Prairies relative to the current climate was calculated. The results project an annual mean $0.4-12.7 \%$ increase in precipitation for 2050 , and for 2080 a $0.9-20 \%$ increase, with winter precipitation projected to increase and summer and spring precipitation projected to decrease for both time periods (Töyrä et al. 2005). Annual mean temperatures were projected to increase $1.8-3.6^{\circ} \mathrm{C}$ for 2050 and $2.5-5.5^{\circ} \mathrm{C}$ for 2080 , with temperatures projected to increase in every season (Töyrä et al. 2005). The wide range in the projection of precipitation highlights the uncertainty surrounding future precipitation trends.

In the headwaters of the NSRB in the Canadian Rocky Mountains, Demuth and Pietroniro (2003) used seven GCMs and the same A2 and B2 emissions scenarios to project temperature and precipitation centered on 2050. The resulting average climate values for 2050, 
relative to the 1961-1990 current observed climate data, projected increases in precipitation for every month throughout the year of approximately $1-25 \mathrm{~mm}$ per month, with the exception of three GCMs which projected decreases in precipitation in the summer months May to September in the range of $1-10 \mathrm{~mm}$ per month, in addition increases in temperature were projected for every month of between $1-5^{\circ} \mathrm{C}$ (Demuth and Pietroniro 2003).

\subsubsection{Effects of future climate change on glaciers}

The general agreement of GCMs in projecting increasing temperatures into the future is mainly due to the application of future scenarios projecting a continuation of the increasing emission rates of most of the atmospheric greenhouse gases. For example, global $\mathrm{CO}_{2}$ concentrations have risen by $3 \%$, and a far more potent greenhouse gas HFC-23 has risen by approximately 40\% just from 1999-2005 (Kargel et al. 2005). Continuing emissions and increasing temperatures imply that glacier mass balance will likely continue its negative trend into the future, resulting in glacier volume loss each year with a mass balance response lag time of one year (Dyurgerov and Meier 2000). It is also projected that the dynamic readjustment of glacier margins as a result of cumulative delayed response to previous climate warming (Demuth and Keller 2006) will cause a retreat and loss of glacier area into the future. For example, a study by Holdsworth et al. (2006) based on mass balance data, glacier ice thickness and a response model by Jóhannesson et al. (1989) calculated the response time of Peyto Glacier for the adjustment of glacier margin extents through ice flow and sliding to be thirty seven years.

Whilst future precipitation projections are variable and uncertain, it is possible that increases in precipitation, especially in the winter and spring as projected by Demuth and Pietroniro (2003) for the NSRB, could offset this projected glacier decline as a result of 
temperature increase. In a study of the correlation between climate variables and distribution of glacier ice in the Canadian Rockies, spring precipitation was found to be on average the dominant control on glacier distribution, followed by annual temperature and winter precipitation (Shea et al. 2004). It is thought, however, that in terms of the sensitivity of glaciers to climate change, temperature variations will have a greater impact relative to precipitation (e.g. Singh et al. 2006) because of the compounding influence of temperature in expanding the ablation area, lengthening the melt season, increasing the extent of melt at a given site, and increasing the proportion of precipitation falling as rain instead of snow (Marshall 2006). There are other uncertainties in projecting glacier decline such as the effects of varying cloud cover (Meier 1969) which are rarely included in GCMs, although changes in the amount or type of cloud cover could intensify or offset changes in runoff due to temperature variations (Brubaker and Rango 1996). Whilst Munro (2006) notes that cloud cover over snow will reduce the net longwave radiation loss, increasing snowmelt and thus revealing a greater area of glacier ice for melt earlier in the season, the effects of cloud over glacier ice are expected to reduce ablation rates since solar radiation is the most powerful energy flux. Therefore, whilst it is generally agreed that glacier decline will continue into the future, the rate of decline is difficult to predict and include in modelling studies of future climate change due to the many uncertainties surrounding future climate change and the impact it may have on glaciers.

\subsubsection{Projecting the rate of future glacier decline}

On a regional scale, the rate of glacier decline is difficult to project since glacier response to climate variations is individual, depending on many local factors such as glacier shape, size, steepness and ice depth. Furthermore, it is unlikely that a glacier will respond only by expansion 
or contraction of its terminus without modification of its geometry and/or flow dynamics in another area (Furbish and Andrews 1984, Brocklehurst and Whipple 2004). Studies of glacier area decline also have to consider that glacier mass loss due to glacier thinning is not included, and significant amounts of surface lowering have been detected on glaciers (e.g. Peyto Glacier, Hopkinson and Demuth 2006). Glacier hypsometry (the frequency distribution of elevations) has been the subject of much research and is found to dictate how responsive the glacier mass balance is to sustained climate change (Furbish and Andrews 1984). For example, climate warming corresponding to an increase in the snowline by $200 \mathrm{~m}$ at a particular glacier location would have a greater influence on low sloping ice masses than steep ones (Marshall 2006). This is due to the larger area of ice that is exposed and subject to ablation on a low sloping glacier as a result of the rise in snowline relative to the ice area exposed on a steep slope. It is also likely that positive feedbacks will enhance glacier decline, such as thermal radiation emitted from bare rock continuously exposed from under the ice as the glacier area reduces, or the general decrease in glacier albedo after a number of years of strong negative mass balance, both resulting in a nonlinear decrease in glacier area (Paul et al. 2004). In addition, the geological setting of a glacier can exert significant control on local climate and thus glacier response. For example, glaciers in basins that receive reliable snow input from avalanches or wind-blown snow accumulation may be less susceptible to climate changes (Kuhn 1993).

Attempts have been made to predict the time in which glaciers will disappear based on past and current retreat rates and future climate scenarios. Hopkinson and Young (1998) for instance, propose that glaciers in the Bow Valley, Alberta, could disappear in approximately 150 years if they continue to deplete at current rates. This is, however, an unrealistic prediction due to the individualistic response of glaciers, and also because it ignores the possibility that glaciers 
may reach a new, smaller equilibrium with future climate change. As long as temperatures remain cool enough for permanent snow and ice to exist in the upper reaches of the basin, it is possible that a glacier will not disappear completely. Indeed Stahl et al. (2008) modelled glacier decline under continued current climate and future climate change scenarios for a glacierised basin in British Columbia and found that mass balances gradually approached zero and reached equilibrium for the current climate scenario after approximately 90 years of simulation time, with a loss in area of $20 \%$. Continuing negative mass balances, however, were observed with no sign of reaching equilibrium when future warming climate change scenarios were applied. Despite the lack of certainty in future precipitation projections and in the effects of climate change on individual glaciers, with the current trends of glacier decline and projected increasing temperatures, it is necessary to assess the impact of glaciers on streamflow and their contribution to the N and SSRB in order to prepare for future possible effects of glacier decline.

\subsection{Effect of Climate Change and Glacier Variations on Streamflow in the $\mathrm{N}$ and SSRB \\ 2.3.1 Impacts of climate change on streamflow}

The effects of glacier decline and climate change are especially important to asses for basins of the North and South Saskatchewan Rivers, for which climate change is a cause for concern regardless of potential variations in glacier contribution. Temperatures are expected to increase in the headwater basins in the mountains and on the Prairies (Töyrä et al. 2005, Demuth and Pietroniro 2003), and with the uncertainty in precipitation projections, this raises concerns over water supply in both these regions. Whilst variations in precipitation generally alter the volume of runoff, temperature changes generally affect the timing due to increased temperatures reducing the relative amount of winter precipitation falling as snow, and resulting in earlier melt 
of the snowpack which leads to a shift in the peak hydrograph to earlier in spring (Barnett et al. 2005). These changes in streamflow regime may cause problems for those that rely on its water supply. Water management systems are designed on the basis of the timing of the spring peak flow, which is much more strongly related to temperature than precipitation, and there is no indication from climate models that there will be a seasonal shift of precipitation to the summer months to compensate for these earlier peak flows (Barnett et al. 2005). In addition, variations in $\mathrm{N}$ and SSRB streamflow modelled using WATFLOOD centered on 2050 under a number of GCM climate projections (as evaluated by Töyrä et al. 2005) indicates that mean streamflows will decrease even with glaciers remaining at their current extent (Brenda Toth, personal communication). The impacts of these projected reductions in streamflow and earlier peak flow therefore need to be considered.

\subsubsection{Impacts of streamflow variability in the $\mathrm{N}$ and SSRB headwaters}

The North and South Saskatchewan Rivers supply agriculture, domestic users, the tourist economy, and industries such as resource extraction and hydroelectric power stations. The latter of which is of particular importance since power is provided to many users downstream from the headwaters (Demuth et al., 2008). In addition, a recent forum of Canadian water resource and hydro-power specialists (C-CAIRN 2006) determined that hydrological variability is the most important source of financial risk to the hydro-power industry, more so than that associated with other factors combined, such as damage to infrastructure and market fluctuations. One of the hydroelectric power stations in the Rocky Mountains is at Abraham Lake on the North Saskatchewan River main stem fed by the Mistaya, Siffleur and Cline Rivers. It was created in 1977 by the construction of the Bighorn Dam and hydroelectric station (118 MW) (Demuth et al. 
2008) and is the largest facility on the eastern slopes generating enough electricity to supply the equivalent of 58,300 Alberta households (Trans-Alta Utilities 2006). Another concern in the headwaters is the impact of potential streamflow variations on the in-stream ecology and surrounding riparian habitats (for a detailed assessment see Pietroniro et al. internal report). For example, increases in water temperature as a likely result of air temperature rise could affect water quality parameters and biotic processes (Meyer et al. 1999), and water temperature is critical in the distribution of fish species. Bull Trout (Salvelinus confluentus) for example, listed as 'sensitive' in Alberta, are found in the upper reaches and headwaters of the NSRB (Hunt et al. 1997) and require cold water temperatures for their survival (Eaton and Scheller 1996).

\subsubsection{Impacts of streamflow variability on the Canadian Prairies}

On the Prairies, the growing population and economy, increased demand for water for irrigation, and competition with other water requirements such as maintaining in-stream flow needs and the Prairie Provinces water apportionment agreement to pass fifty per cent of water to the next province raises concerns over possible future streamflow variations (Barnett et al. 2005). Over much of the semi-arid Prairies, potential evaporation exceeds precipitation (Conly and van der Kamp 2001), and as a result the Prairies are considered very sensitive to any small variations in future water balance parameters caused by large-scale changes to temperature and precipitation (Töyrä et al. 2005). The southern Prairie Provinces (Alberta, Saskatchewan and Manitoba) support the majority of Canadian agricultural land which distributes grain products across the world (Töyrä et al. 2005). Bonsal et al. (1999) note that average precipitation is just sufficient to sustain agricultural production thus any precipitation shortages have severe effects. Climate studies are in general agreement over future projected increases in temperature and 
associated decreases in summer soil moisture, accompanied by increased severity and frequency of droughts (Barnet et al. 2005). It is therefore highly likely that the demand for irrigation and thus a reliable water supply will continue to increase into the future. Since the majority of this water supply for irrigation is from surface water, this places additional stress on the fresh river water resources, such as the North and South Saskatchewan Rivers of which approximately $90 \%$ originates in the mountainous headwater region (SSRB 2007).

\subsubsection{Glacial impact on streamflow}

The declining mean streamflow trends and earlier spring peak flows as a direct result of climate change and snowmelt runoff variations are expected to be exacerbated by the effects of glacier decline. Glacier-fed rivers have distinctive discharge hydrographs and in general, the greater the glacierised area of the basin, the stronger the glacier's influence (Chen and Ohmura 1990b). The streamflow of glacierised basins can be described by having very low winter magnitude and a larger and extended peak summer flow with respect to non-glacierised basins. This seasonal variation is the result of snow accumulation on the glacier, which remains longer on the cooler ice surface relative to the surrounding land surfaces (Schuster and Young 2006), and the delayed, extensive supply of meltwater from the exposed lower albedo glacier ice in the late summer well after the snowpack is exhausted (Meier 1969, Fountain and Tangborn 1985, Chen and Ohmura 1990b). In addition, the glacier as a system delays runoff due to the release of

temporarily stored supra-, en- and sub-glacial meltwater with the progressive development of the glacial drainage system towards the end of the summer (Fountain and Tangborn 1985, Fountain and Walder 1998, Richards et al. 1996). Whilst glacier ice is impermeable, meltwater travels through the glacier in a network of en-glacial conduits and sub-glacial drainage channels which 
enlarge during the melt season, and can refreeze in the winter (Fountain and Walder 1998). The role of firn (snow that has survived at least one melt season) which overlays the glacier ice in the accumulation area has been the subject of little research, but was found to delay water transport through the glacier (and therefore delay runoff) by temporarily storing water in the zone between the permeable firn and impermeable ice (De Woul et al. 2006). Glaciers also regulate streamflow annually as well as seasonally by acting as natural adjusting reservoirs that reduce streamflow variability by increasing runoff during warm, dry periods (in years and months when there is low runoff in non-glacierised basins) and by storing water in wet, cool periods (Meier and Tangborn, 1961, Krimmel and Tangborn 1974, Fountain and Tangborn, 1985). Indeed, when modelling the response of a glacierised and non-glacierised basin to increases in temperature, Singh and Bengtsson (2005) found the short term impact to be opposite in the two basins due to the extensive supply of runoff from the glacier ice, concluding that non-glacierised, snowmelt regime basins are more sensitive to temperature increase in terms of reduction in water availability. Similarly, a study of Peyto Glacier in the NSRB headwaters, found that years of high glacier runoff (such as 1970) tended to coincide with years of low non-glacier derived runoff (Schuster and Young 2006).

The presence of glaciers in a basin also affects the response of streamflow to variability in large-scale circulation patterns such as the PDO, PNA and ENSO (Fleming et al. 2006). For example, Lafrenière and Sharp (2003) found that glacierised and non-glacierised streams feeding into Bow Lake, Alberta, responded differently to the 1997-1998 El Niño event, in that the early disappearance of the snowpack resulted in low seasonal discharge from the non-glacierised basin, which in the glacierised basin was compensated by high runoff from the glacier and thus was less affected by the event. Seasonal and annual coefficients of variation $(C V)$ of streamflow 
generally decrease with increasing glacier cover having implications for the relative stability and predictability of water supply for hydroelectric power, ecological habitats and flood hazards (Fleming and Clarke 2005). There is some evidence from studies in Washington, the European Alps and British Columbia to suggest that a minimum annual flow $C V$ is found at intermediate values of glacier cover (Fountain and Tangborn 1985, Rothlisberger and Lang 1987, Chen and Ohmura 1990b, Moore 1992). The streamflow $C V$ is expected to increase after a critical value of glacier cover when runoff variability is dominated by the variability of the glacial net balance (Moore 1992). This evidence is, however, inconclusive as it is generally based on a result from a single highly glacierised basin, and a similar study in southwest Yukon and northwest British Columbia found no evidence of a minimum $C V$ at intermediate values (Fleming and Clarke 2005).

Glaciers influence streamflow variability on a variety of time scales (Fountain and Tangborn 1985). In addition to annual and seasonal variability, diurnal fluctuations resulting from the increase in energy available during the day for ice melt can be observed in streamflow below a glacier (Collier 1959). For Peyto Glacier the maximum flow in the daily hydrograph at midsummer was observed several hours after the maximum heat flux, the delay thought to be mainly the result of flow in the channel network (Derikx 1975). These fluctuations tend to be smoothed with distance downstream from the glacier, partly due to cumulative snowmelt inputs at lower elevations, groundwater and rainfall inputs. Collier (1959) observed these daily fluctuations at five gauging stations on the North Saskatchewan River from Saskatchewan Crossing to Edmonton for a study period 1950-1956, with the most apparent fluctuations in late summer. Ice melt is well correlated with air temperature since the latter is a good index of energy 
supply to the glacier surface (Chen and Ohmura 1990b), and ice melt is often calculated as a residual from the energy balance (Derikx 1975).

The Inter-governmental Panel on Climate Change (IPCC) Fourth Assessment Report (2007) has stated with high confidence that observational evidence suggests that there is increased runoff and earlier spring peak discharge in many glacier and snow-fed rivers as a result of climate change. This projection assumes that the increase in volume loss (wastage) from glaciers is causing an increase in streamflow. This effect, however, can only be short term because as the glacier recedes the decrease in basin ice cover will eventually limit the volume of meltwater produced, even if climate changes sustain greater melt per unit area (Moore and Demuth 2001). An example of these two phases can be seen in the modelled streamflow from 1990-2140 for glacierised basins of the Himalayas in which flow initially increases before decreasing as the glacier area declines (Rees and Collins 2006). Studies have been conducted specifically on basins in the Rocky Mountains to determine whether this increased flow phase has already occurred in this region.

\subsubsection{Glacial impact on streamflow in the $\mathrm{N}$ and SSRB}

Rood et al. (2008) examined past seasonal streamflow trends in the Rocky Mountains, and observed the strongest patterns of change in streamflow seasonality for rivers of the Saskatchewan River basin, including some of the headwater basins of the North and South Saskatchewan Rivers such as the Bow River at Banff with one of the most complete data sets dating back to 1911. Rood et al. (2008) found that winter flows generally slightly increased over the record, with increases of approximately $0.1 \%$ per year for the Bow River at Banff, though this had little impact on the total flow since winter flows are naturally very low. The larger 
seasonal change was the decrease of summer flows, especially in late summer, with the Bow River at Banff flows showing statistically significant decline in July to September with a magnitude of approximately $0.2 \%$ per year, and the North Saskatchewan and Red Deer Rivers showing dramatic reductions of late summer flow of approximately $1 \%$ per year, which is important relative to total discharge since June and July are the highest flow months (Rood et al. 2008). It was also observed that spring runoff and peak flows were occurring earlier, and as a result of this and declining late summer flows, they looked at the effect on floodplain trees and predicted that there would be losses of seedlings, saplings and older trees due to increasing, chronic drought stress as a result of reduced riparian groundwater recharge in the late summer (Rood et al. 2008). This observed advance in the spring runoff and peak flows is the result of a diminished and earlier melting snowpack due to increasing winter and spring temperatures (Rood et al. 2008). The observed decline in late summer streamflows despite the increased time length of glacier ice exposure for ablation indicates that glacier size is limiting the volume of meltwater produced, thus glacier contribution to streamflow will continue to decline even with increased temperatures.

In addition, findings by Demuth and Pietroniro (2003) studying streamflow regimes in several headwater catchments of the NSRB indicate that the regulatory influence of glaciers is in significant decline, at least at seasonal scales, and appears to be in association with glacier cover contraction over the latter half of the twentieth century. They conclude that despite significant increases in precipitation in the late summer months since 1950 for the montane region, flow volumes over the late summer period in glacierised basins have been declining since the mid 1900s (Demuth and Pietroniro 2003). A simulation of a British Columbia glacierised basin (Stahl et al. 2008) using future climate scenarios for the next 50 to 100 years concluded that increases 
in winter precipitation, even up to $15 \%$ applied in tests, were not large enough to offset the declining August streamflow trends, and that glacier retreat (simulated in the model) seemed to be the major cause of these negative trends. Similar negative trends in summer streamflow have been found in glacierised basins in the Coast Mountains, British Columbia, (Moore and Demuth 2001, Stahl and Moore 2006), suggesting that glaciers in this entire region have declined sufficiently such that the short-term increased streamflow phase resulting from increased glacier wastage as predicted by the IPCC may have already passed (Demuth et al. 2008).

The reduced late summer flows as a result of glacier decline will add to the impacts on streamflow previously described as a direct result of climate change and variations in snowmelt runoff. With the spring peak expected to occur earlier, coupled with reduced and less consistent flows in the late summer months at times when irrigation demands are highest, if the storage capacities (e.g. reservoirs) are too small, then much of the runoff will be lost downstream

eventually to the ocean leaving insufficient amounts for use in the summer (Barnett et al. 2005). It therefore is necessary to quantify the amount of water that glaciers contribute to the $\mathrm{N}$ and SSRB in terms of wastage, and the seasonal impact glaciers have on streamflow in terms of Melt, to determine whether glacier decline will have a significant impact on streamflow.

\subsection{Estimating Glacier Contribution to Streamflow}

\subsubsection{Methods}

In addition to analysing the impact of glaciers on streamflow as described above, some attempts have been made to quantify the volume of water derived from glacier ice melt and its contribution to streamflow. Whilst the most physically thorough method for a region is through glacier dynamical modelling (e.g. Oerlemans et al. 1998), this is computationally intensive and 
requires extensive climate data and information on glacier dynamics and routing, which often is not available (Stahl et al. 2008). Other methods are therefore used to estimate glacier runoff, the most common being temperature index based models (e.g. Moore 1992 in British Columbia, Singh et al. 2006 in the Himalayas, De Woul et al. 2006 in Iceland). In addition, a few researchers have modelled the impacts of future climate change on streamflow with glacier area allowed to fluctuate within the model (e.g. Rees and Collins 2006 in the Himalayas, Stahl et al. 2008 in British Columbia). Other methods include estimating glacier volume loss derived from area loss (e.g. Chen and Ohmura 1990a), and calculating glacier runoff as a residual of the energy balance which requires detailed field measurements at the ice surface (Goodison 1972, Munro 2006). Methods such as analysing stream geochemistry have also been employed to determine the glacier runoff component of streamflow (e.g. Richards et al. 1996, Mark and Seltzer 2003). A number of these methods have been applied to basins of the North and South Saskatchewan Rivers, and these are the studies that will be reviewed in this section. The results will also be used to compare to the findings of this thesis where possible.

\subsubsection{Glacier wastage}

There have been few attempts to measure the thickness of glaciers because this is difficult, which limits the possibilities of direct volume change estimates. Some research, however, has been done on Peyto Glacier. Seismically determined depth data were calculated below the ice fall and used to estimate the average thickness of the glacier (Hobson and Jobin 1975). Radar ice thickness measurements were first made in 1983 (Holdsworth et al. 1983), and again from 1984-1986 to correspond with those made by Goodman (1975) in 1970, also using a

radar system. Holdsworth et al. (2006) determined from a comparison of seismically determined 
depth data and radar ice thickness data that Peyto Glacier lost at least $18 \%$ of its total volume, or $139 \times 10^{6} \mathrm{~m}^{3}$, from 1966-1984 (Holdsworth et al. 2006). Wallace (1995) also estimated Peyto Glacier volume loss equalling $1088.6 \times 10^{6} \mathrm{~m}^{3}$ from 1896-1966, a $60 \%$ loss of the 1896 volume. Unfortunately these estimates could not be found as a percentage contribution to streamflow due to the lack of a flow gauge for the entire time period at Peyto Glacier basin. Collier (1958) estimated the volume loss of Peyto Glacier from 1950-1956 by mapping the movement of the ice front in reference to fixed points on the valley and determining the depth loss from the difference in glacier profiles made. There were difficulties, however, in obtaining continuous reliable measurements of stream discharge at the foot of the glacier due to extremely rough stream bed conditions so that the glacier contribution to streamflow could not be calculated.

\subsubsection{Glacier wastage contribution to flow}

Henoch (1971) calculated glacier wastage and its contribution to runoff in the upper North Saskatchewan River basin for 1948-1966. He divided the area into two parts, the North Saskatchewan River at Saskatchewan Crossing basin and the Mistaya River at Saskatchewan Crossing basin, which both have streamflow records extending back to the 1950s. Glacier area change was estimated from an examination of air photographs. Many of the photographs from 1948, however, did not meet the requirement of having been taken at the end of the ablation season when most of the seasonal snow is gone and the glacier ice extents therefore could not be easily determined. Glacier area was found to decrease by $10 \%$ in the 18 year period. Surface lowering was then calculated using mass balance data from Peyto available from 1965 by distributing the loss (negative balance was observed) from 1965-68 over the glacier and then extrapolating over the 18 year time period. This extrapolation of the negative mass balance 
observed in the later years of the time period may be inaccurate for the earlier years since temperatures show an increasing trend, thus implying increased loss with time, and the lack of mass balance data therefore is a limiting factor here. Results show that glacier wastage contributed $4 \%$ of the annual flow of the upper North Saskatchewan River, which is concluded to be small for this area of high precipitation (Henoch 1971). Whilst the importance of the timing of glacier wastage is discussed, the contribution to the summer period is not calculated and the importance of the seasonal impact of Melt is not considered, resulting in the author suggesting that long term glacier shrinkage is not a pressing problem.

Hopkinson and Young (1998) calculated the glacier wastage contribution to flow for the Bow River at Banff (approximately 3\% glacierised) in the SSRB by estimating the net volume loss from 1953-1993 using a volume-area relationship (Chen and Ohmura 1990a) on National Topographic System (NTS) map derived glacier areas. Additionally, mass balance data from Peyto Glacier was used as a surrogate for glacier mass balance in the region to divide the net mass loss into yearly volume loss estimates. It was found that from 1953-1993 there was a net change in glacier volume of $934 \times 10^{6} \mathrm{~m}^{3}$ water equivalent in the Bow Valley above Banff as a result of $1215 \times 10^{6} \mathrm{~m}^{3}$ total wastage (sum of $b_{w}+b_{s}$ in negative balance years) and $281 \times 10^{6} \mathrm{~m}^{3}$ total accumulation (sum of $b_{w}+b_{s}$ in positive balance years) over the time period, the latter of which was concentrated in the early years. Net glacier wastage therefore contributed only $1.8 \%$ of total basin yield. Hopkinson and Young (1998) also considered seasonal contributions and conclude that wastage is clearly important in low flow times since they found that in 1970 , the lowest flow on record at Banff, glacier wastage contributed approximately $56 \%$ of total flow in August. There are limitations to the study, however, in that the photographs used for glacier area assessment were of poor quality and the Peyto mass balance record had gaps which required 
interpolation. No mention is made of the seasonal impacts of Melt on streamflow, but this is a good assessment of wastage contributions, which looks at flows both annually and seasonally. Young (1991) and Glenday (1991) looked at glacier wastage contribution to the whole Mistaya basin, in which Peyto Glacier is located (NSRB). The volumetric change of Peyto Glacier was calculated by comparing 1966 aerial photography derived maps with the results of re-mapping the glacier in 1989 using a ground based total survey station. The area and volume changes were then calculated within zones defined by $100 \mathrm{~m} 1966$ contours and the 1966 glacier edge. Peyto Glacier was found to have decreased from 13.2-12.1 km² from 1966-89, with a total volume decrease of $170 \times 10^{6} \mathrm{~m}^{3}$. Peyto Glacier wastage was extrapolated to the other glaciers in the Mistaya basin with total glacier cover in the Mistaya basin decreasing by $11 \%$, which is close to the $10 \%$ decrease found by Henoch (1971) despite applying to a later time period. Total volumetric loss over the time period was found to be $340 \times 10^{6} \mathrm{~m}^{3}$ for the Mistaya basin, which represented $6 \%$ of the total basin yield. Again this study does not consider the seasonal impacts of Melt, but similar to Hopkinson and Young (1998) the importance of the timing of glacier contribution is identified, with a focus on the warm, dry year of 1970 when glacier wastage was found to contribute $25 \%$ of the total basin yield.

More recent analysis has used improved techniques to study Peyto Glacier. Hopkinson and Demuth (2006) use airborne Light Detection And Ranging (LiDAR) technology which has the ability to map larger areas of surface topography at greater speeds and higher resolutions than previous methods. They compare LiDAR digital elevation models (DEMs) of Peyto Glacier basin for 2000 and 2002, and by calculating the differences in elevation find the total and spatial variability of surface downwasting (or growth) in the basin. The volume change was used to give the total wastage runoff from Peyto Glacier and the ice-cored moraines in the two years which 
was $22 \times 10^{6} \mathrm{~m}^{3}$ water equivalent. Hopkinson and Demuth (2006) determined that the ice-cored moraines around Peyto Glacier are melting and contributed $6 \%$ of the total glacier wastage runoff from 2000-2002. After extrapolating the results to the other glaciers in the Mistaya River basin glacier wastage was estimated to contribute $16 \%$ of the total basin runoff from 2000-2002. Other observations by Hopkinson and Demuth (2006) include that there was no surface growth over Peyto Glacier and that downwasting varied spatially from nearly $0 \mathrm{~m}$ at the highest elevations to over $10 \mathrm{~m}$ on parts of the glacier terminus, including regions of extreme change of $20 \mathrm{~m}$ due to ice surface collapse, with a total average surface melt depth of approximately $3.4 \mathrm{~m}$. Whilst this study considers the impacts of glacier wastage only, it uses a much more accurate method to determine volume loss than the previously used air photographs, and thus the results are considered to be more reliable.

Research on Peyto Glacier is ongoing and it is thought that wastage volumes from the glacier could be increasing indicating that perhaps Peyto Glacier is not over the increased flow phase indicated by the IPCC (2006) (Hopkinson, personal communication CGU 2008.). Unfortunately, streamflow records for Peyto Glacier basin cannot be analysed for trends or used to calculate wastage contributions due to the lack of a continuous, long term record, with reliable data available from 1968 to 1977 only (Schuster and Young 2006). Given the evidence from other research of decreasing streamflow trends in the late summer months for this region, it may be that whilst Peyto Glacier is large enough still that it has not reached the decreasing wastage with decreasing area phase, the many smaller glaciers in the region have. Alternatively, the decreasing seasonal late summer streamflow trends may be the result of decreasing Melt runoff as less snowfall accumulates into the glacier system and the volume of ice stored in the glacier to 
be released after snowmelt is reduced, masking possible increased seasonal glacier wastage contributions to streamflow.

Demuth et al. (2008) calculated the volume loss of glaciers in the N and SSRB using a volume-area relationship (Chen and Ohmura 1990a, Bahr et al. 1997) and calculated the wastage as a percentage of streamflow for seven basins where observed flows were available from 19751998. This was completed for three basins in the NSRB: Mistaya River at Crossing, North Saskatchewan River at Whirlpool and North Saskatchewan River below Bighorn plant, the latter of which is regulated, and for four basins in the SSRB: Red Deer below Burnt Timber, Bow River at Lake Louise, Bow River at Banff and Bow River below Ghost Reservoir, again the latter of which is regulated. The volume-area calculations have since been re-calculated after correcting the allocation of glacier cover to each basin and re-determining the cumulative glacier cover. As part of this thesis the percentage wastage contributions to flow have been re-calculated and extended for a larger number of basins with further analysis. A discussion of the volumearea relationship used can be found in the methodology chapter of this thesis in section 4.5.

\subsubsection{Glacier wastage and Melt contribution to flow}

Loijens (1974) calculated glacier volume loss (wastage) and total runoff from the glacierised basin areas as a percentage of streamflow in the Mistaya River basin at Saskatchewan Crossing (12\% glacierised). This was done by gauging three highly glacierised basins, Peyto, Delta and Barbette, which comprise $72 \%$ of total glacier cover of the Mistaya River basin, for the period from $14^{\text {th }}$ July to the $3^{\text {rd }}$ September 1971 . This time period was selected due to the lower than normal temperatures in June and early July which delayed snowmelt so that the first appearance of glacier ice was in mid-July, when it is normally snow free in mid-June, and the 
main ice melt season ended at the start of September in 1971. The hydrological balance for each basin was calculated with the glacier runoff as the residual, glacier runoff was defined as total runoff from the glacierised area of each basin, therefore including snowmelt from the accumulation area and any precipitation (snow and/or rain) that fell on the glacier surface during this time period. Glacier cover and measurements of snow accumulation for the non-glacier portions of the basin were taken from air photographs, evaporation and condensation were assumed to be zero (based on Fohn's (1973) finding that these two components are approximately equal over snow, and net evaporation over the non-glacierised area is small), change in storage was assumed zero, and precipitation was measured at climate stations. For non-gauged glaciers in the Mistaya basin, glacier runoff was estimated by extrapolating Peyto summer mass balance data collected in three time periods from $5^{\text {th }}$ May to $15^{\text {th }}$ September. This approach, however, was not used on Peyto Glacier due to the extensive runoff delays meaning that runoff could not be computed directly from balance data in the short seven week time period. Whilst this would also be limiting for the non-gauged basins, Peyto Glacier is relatively large so that runoff delays are more likely to be much greater than the smaller glaciers to which this approach was applied. It is acknowledged that this approach is based on glacier areas derived from air photography from 1949 to 1955 which had to be reduced by $10 \%$ to give an area for 1971 (in accordance with the estimate of glacier shrinkage made by Henoch 1971), and the assumptions made are likely inaccurate. It is, however, considered a best assessment given the equipment and data available at that time. Annual ice volume loss or wastage was calculated by extrapolating Peyto annual mass balance data to the other glaciers in the Mistaya basin, and the wastage glacier contribution was calculated both annually and seasonally. 
The results from Loijens' (1974) research showed that total annual streamflow from the Mistaya River basin in 1971 was $202 \times 10^{6} \mathrm{~m}^{3}$, with $46 \%$ of the annual flow occurring in the July to September time period of $94 \times 10^{6} \mathrm{~m}^{3}$. Of this, glacier wastage contributed $29 \times 10^{6} \mathrm{~m}^{3}$ which was $31 \%$ of the July to September flow, and 14\% of the annual flow (Loijens 1974). It is dangerous to assume that glacier wastage from Peyto Glacier can be extrapolated to all other glaciers in the Mistaya basin since Peyto is the largest glacier in the basin, and also due to the individual response of glaciers as a result of local climate and location differences (section 2.2.3), therefore this may not be an accurate estimation of wastage from the Mistaya basin. Glacier runoff calculated for Peyto Glacier basin as $33.20 \times 10^{6} \mathrm{~m}^{3}$ (Loijens 1974) can be used to estimate combined glacier wastage and Melt runoff. Glacier runoff here (as the residual from the basin hydrological balance) includes ice melt, snowmelt from the accumulation zone (not the ablation zone since the time period was selected due to the absence of snow in the ablation zone), and any precipitation runoff from the glacier. Therefore, if the July to September precipitation runoff from the non-glacierised area of the basin, $\left(1.68 \times 10^{6} \mathrm{~m}^{3}\right.$, Loijens 1974$)$ is assumed to equal the precipitation runoff from the glacier, and the summer mass balance above the ELA in 1971 is assumed to equal the snowmelt runoff from the accumulation zone $\left(3.48 \times 10^{6} \mathrm{~m}^{3}\right.$, Young 1981) (though this is an overestimate since it includes snowmelt from May and June also), these can be subtracted from the glacier runoff in Loijens (1974) to give an estimation of glacier wastage and Melt from Peyto glacier in 1971. The calculation respective to the terms described is as follows: $33.20-1.68-3.48=28 \times 10^{6} \mathrm{~m}^{3}$. Whilst there is no discussion of the difference between glacier wastage and Melt, and glacier runoff is calculated to include snowmelt, precipitation and ice melt from glaciers thus the impact of glaciers on streamflow focuses on the calculated glacier wastage, Loijens (1974) concludes that the timing of glacier 
contribution is a very important factor in its significance to streamflow. It could also be concluded from this study that wastage substantially contributes to streamflow of the Mistaya River basin both annually and in the late summer months.

Derikx (1973) applied a groundwater system model to simulate drainage from Peyto Glacier for the ablation period (July to September) of 1968. Even though the groundwater system is a very crude approximation of the actual drainage system, results showed a fair correspondence of simulated and measured streamflow monitored in the melt stream below the glacier, suggesting that the glacier drainage system as a whole has characteristics similar to that of a groundwater system. Whilst it is noted that this approach does not determine in detail the effect of all the factors on runoff- indeed it is extremely difficult to do so- this study of the overall response of the glacier allows an evaluation of the most significant relationships. For example, the results show that the response of the drainage system to warming was clearly slower in June, when the glacier was still snow covered, but very high discharge and faster response was seen in July post snowmelt. In September the drainage system channels became constricted by the freezing of meltwater slowing the system. Derikx (1975) continued work on Peyto Glacier and determined runoff from a $5320 \mathrm{~m}^{2}$ experimental site on the glacier tongue from the $2^{\text {nd }}$ to $7^{\text {th }}$ August 1970 as the residual from the measured hourly energy balance. He calculated the total ice melt to be $348 \mathrm{~mm}$ water equivalent for this six day time period. Whilst it is not stated, ice melt as a residual of the heat balance will include both glacier wastage and Melt. The contribution to streamflow is not calculated here, though streamflow data is available to do so if the ice melt was extrapolated over the ablation area.

Finally, Young (1982) modelled the separate components of streamflow from the Peyto Glacier basin from 1967-1974. Grid squares measuring $100 \mathrm{~m}$ by $100 \mathrm{~m}$ were used to model the 
basin using local temperature and precipitation measurements to determine rainfall, snowfall and snowmelt runoff from May to October. Glacier ice and firn runoff was calculated from stake measurements of accumulation and ablation, and also by linking specific ice melt to mean daily temperature and using the lapse rate corrected temperature to calculate ice melt. Young (1982) found glacier ice and firn runoff to average together $9.2 \times 10^{6} \mathrm{~m}^{3}$ water equivalent from 19671974 , which is $26 \%$ of the observed streamflow for the months of May to October in this time period. It is not stated (and this is unclear from the methodology) whether this is a measure of glacier wastage or combined wastage and Melt. Again, high amounts of glacier runoff were calculated for the warm, otherwise low flow year of 1970 with runoff equalling $41 \%$ of streamflow from May to October, and this is the only year in which firn melt $\left(12.72 \times 10^{6} \mathrm{~m}^{3}\right)$ was greater than glacier ice melt $\left(10.17 \times 10^{6} \mathrm{~m}^{3}\right)$. Young (1982) concludes that glacier contribution to streamflow is strongly associated with the timing of the progression of the transient snowline up the glacier: the slower the progression, the less glacier ice is exposed for melt for a shorter period of time as a result of cooler temperatures and greater specific winter balance.

\subsection{Limitations and Gaps in Literature}

Despite there being previous research determining glacial impact and contribution to basin streamflow in the North and South Saskatchewan River basins, there is a lack of distinction between glacier wastage and Melt, with the majority of studies looking at glacier wastage. Those that have calculated Melt estimates have only done so for very short time periods in a single year, and none have acknowledged that glacier runoff in terms of Melt is significant only to seasonal streamflow volumes and does not contribute to increased total annual flow volumes. 
This thesis firstly defines glacier wastage and Melt due to the lack of existing clear definitions. Previous studies have also only looked at glacier contribution to single or a small number of basins. Thus there is no regional study of total glacier contribution to the North and South Saskatchewan River basins, so effects downstream are hard to determine. This literature review highlights the lack of data available in the North and South Saskatchewan River basins, especially in terms of glacier data and continuous, long term streamflow records. Due to this lack of glacier data, previous research has focused on Peyto Glacier and results have been extrapolated to other glaciers in the study area. The extrapolation could be misleading since Peyto Glacier has a greater area than the population median (Demuth et al. 2008), and glaciers respond individually to regional climate change according to local conditions. It has been suggested, however, that Peyto Glacier basin is ideal for the development and application of larger-scale hydrological models for glacierised basins due to the relative wealth of data available (Morris 2006). Poor streamflow records limited much of the previous research, in which glacier contribution to streamflow often could not be calculated due to the lack of continuous streamflow records for the time period studied, which is especially true of Peyto Glacier basin. It has therefore been recommended that a streamflow gauge is installed to measure flow at Peyto, given that this is the only glacier in the region with extensive local climate and mass balance data available (Shuster and Young 2006). With concern over future climate change and its effects on streamflow in the North and South Saskatchewan River basin headwaters and on the Prairies, the impacts of projected future glacier decline need to be assessed by determining the quantity of both glacier wastage contribution to streamflow and Melt runoff with its impacts on seasonal streamflow. Those that rely on these rivers can then start to assess whether glacier decline poses a threat to their water supply in terms of volume losses (long term decline in 
wastage) and earlier peak flows (advancement of Melt runoff to the early spring as the ability of the glacier to delay snowmelt decreases), accompanied by a reduction in late summer streamflow. 


\section{Chapter 3}

\subsection{Study Area}

\subsection{The North and South Saskatchewan River Basins}

The North and South Saskatchewan Rivers are major basins of the Nelson River system, with main stems flowing east and northwards across the foothills, prairies and boreal plains, and finally emptying into Hudson's Bay. The headwaters are located on the eastern slopes of the Rocky Mountains along the North American continental divide on the border of British Columbia and Alberta (Figure 3.1) The headwater region elevation ranges from approximately 1200-3490 m.a.s.1. (Demuth et al. 2008), and in a typical basin as described by Young (1991) for the upper NSRB (also applicable to the upper SSRB) the land cover progresses with increasing elevation from lakes, through forest and bare rock surfaces, to glaciers.

The current montane glaciers are the climatological remnants of the Cordilleran Ice Sheet, though the present ice is thought to be at most about 500 years old due to the estimated mass turnover rates (Pietroniro et al. internal report). North-south glacier cover is primarily influenced by latitude (in terms of temperature variation and storm tracks), and glacier cover generally diminishes eastwards due to altitude and a leeward-slope precipitation gradient (Demuth and Pietroniro 2003). Geomorphologic controls, such as reduced snowmelt in hollows, blowing snow drifts, and avalanche settings also influence the glacier distribution. In addition, Paleozoic sedimentary bedrock produces scarp features separated by wide benches of relatively uniform elevation, which at above approximately 2100 m.a.s.1. promote the accumulation of 
snow and support large icefields and many mountain glaciers; outlet valley glaciers nourished by the icefields, also exist (Demuth and Pietroniro 2003).

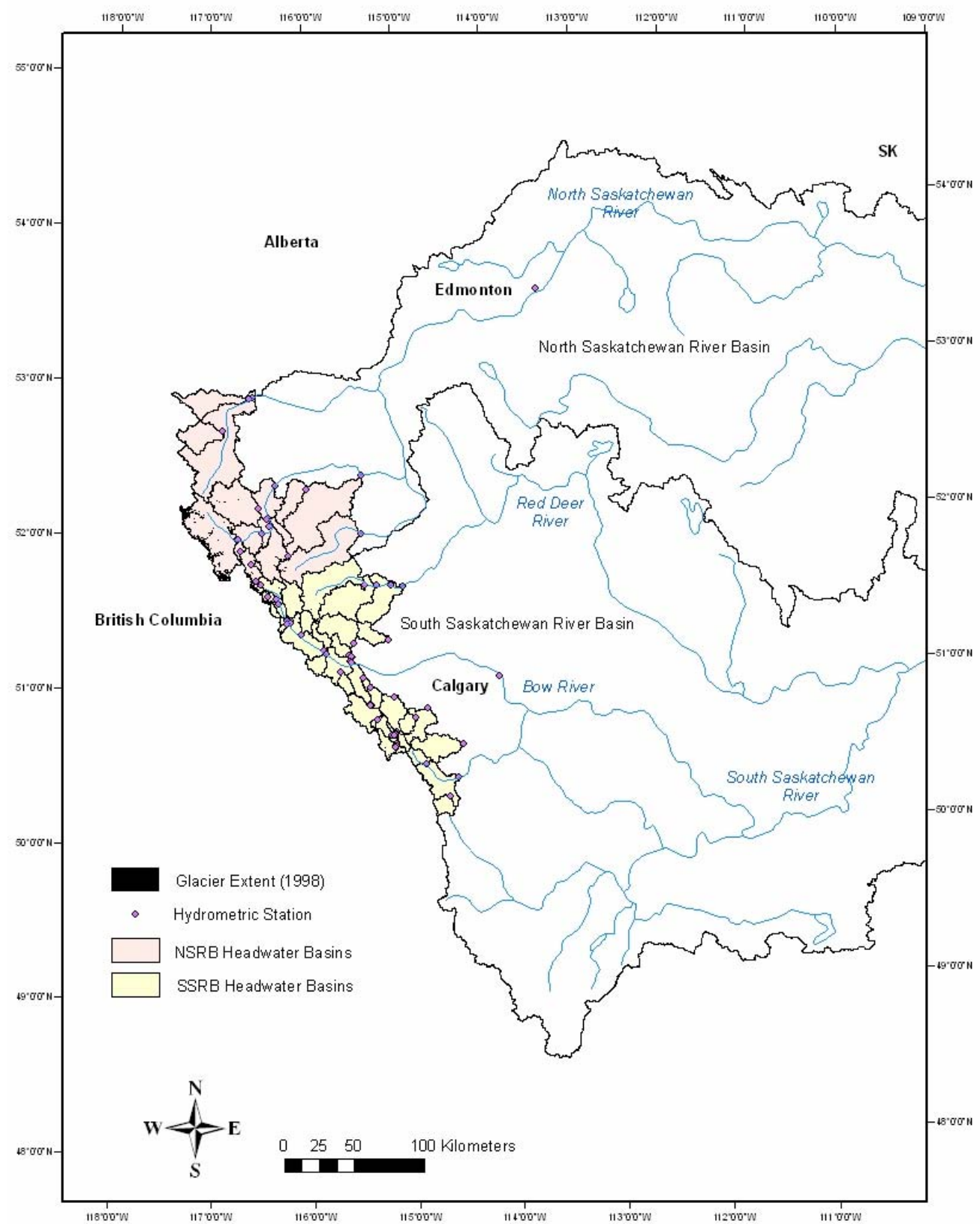

Figure 3.1 The North and South Saskatchewan River basins and headwater sub-basins (Source: Data files from National Hydrology Research Centre, Saskatoon) 


\subsection{The $\mathbf{N}$ and SSRB Headwater Climate}

The regional climate is dominated by westerly air masses from the Pacific Ocean that dump large amounts of moisture on the Coast Mountains in British Columbia. After moving across western British Columbia, the ascending air creates a moist interior continental climate on the Interior Ranges and Rocky Mountains, then a rain shadow effect is produced as the air moves over the continental divide onto the eastward slopes of the Rockies. In mid-winter, snow accumulation can suffer depleting effects due to warmer Chinook conditions, however, easterly winds, which are common in spring, supply the Rocky Mountain eastern slopes and these upslope conditions can bring a significant amount of snow accumulation (as described in Demuth et al. 2008). At the higher elevations, annual precipitation ranges between $800-1500 \mathrm{~mm}$ (Demuth et al. 2008), with average annual total precipitation at Peyto Glacier meteorological station (2245 m.a.s.1.) measured at $857 \mathrm{~mm}$ from 2003-2006, of which $524 \mathrm{~mm}$ (water

equivalent) was snow (Scott Munro, personal communication). The eastern slopes generally have a continental climate with cold, relatively dry winters and warm, wet summers (Banff average annual temperature is approximately $+3{ }^{\circ} \mathrm{C}$ and total precipitation approximately $470 \mathrm{~mm}$ ). Also dry, high-pressure, continental air masses can periodically cause extended periods of very cold winter weather and hot, dry summer weather (Demuth et al. 2008).

\subsection{Glacier Cover in the $\mathbf{N}$ and SSRB Headwaters}

Glacier cover in the headwater regions was determined prior to this study from remotely sensed Landsat-2 MSS, Landsat-5 TM and Landsat-7 ETM images from 1975 and 1998 as described in detail in Pietroniro et al. (internal report). Landsat images from late summer were chosen when the glacier margins were generally free from snow cover and when the ice 
configuration was at, or near, the close of the mass balance year. Automatic classification using a geographical information system (GIS) was used, followed by manual editing. From the automatic classification there were problems with areas of shadow and supra-glacial debris, thus manual editing was required to convert the vectors to closed polygons, correct for areas of shadow and debris covered ice, and remove the vectors outside the drainage basin area.

Pietroniro et al. (internal report) note that this is subjective, but that background knowledge of topography, shadow, cirques and moraines can refine the reliability of the manual editing. Glacier cover measurements were obtained for each headwater basin for 1975 and 1998 from the GIS polygon attributes, and the area change analysed by Demuth et al. (2008). Where fragmentation created distinct glaciers by the exposure of topographic divides, the individual polygon areas were summed and this value used to determine area change.

From this glacier cover data, it is seen that the NSRB is relatively glacier rich with the total glacier cover decreasing from $395-306 \mathrm{~km}^{2}$ (23\% decrease relative to the 1975 glacier cover) from 1975-1998 (Figure 3.2). The SSRB lost a greater percentage of glacier cover (37\% decrease relative to 1975) but with a smaller total glacier cover which decreased from 141-89 $\mathrm{km}^{2}$ (Figure 3.3). Unfortunately, the glacier cover derived from the Landsat Imagery did not include glaciers in the Brazeau basin (NSRB) or the Oldman basin (SSRB), thus these values of total glacier cover are underestimates. 


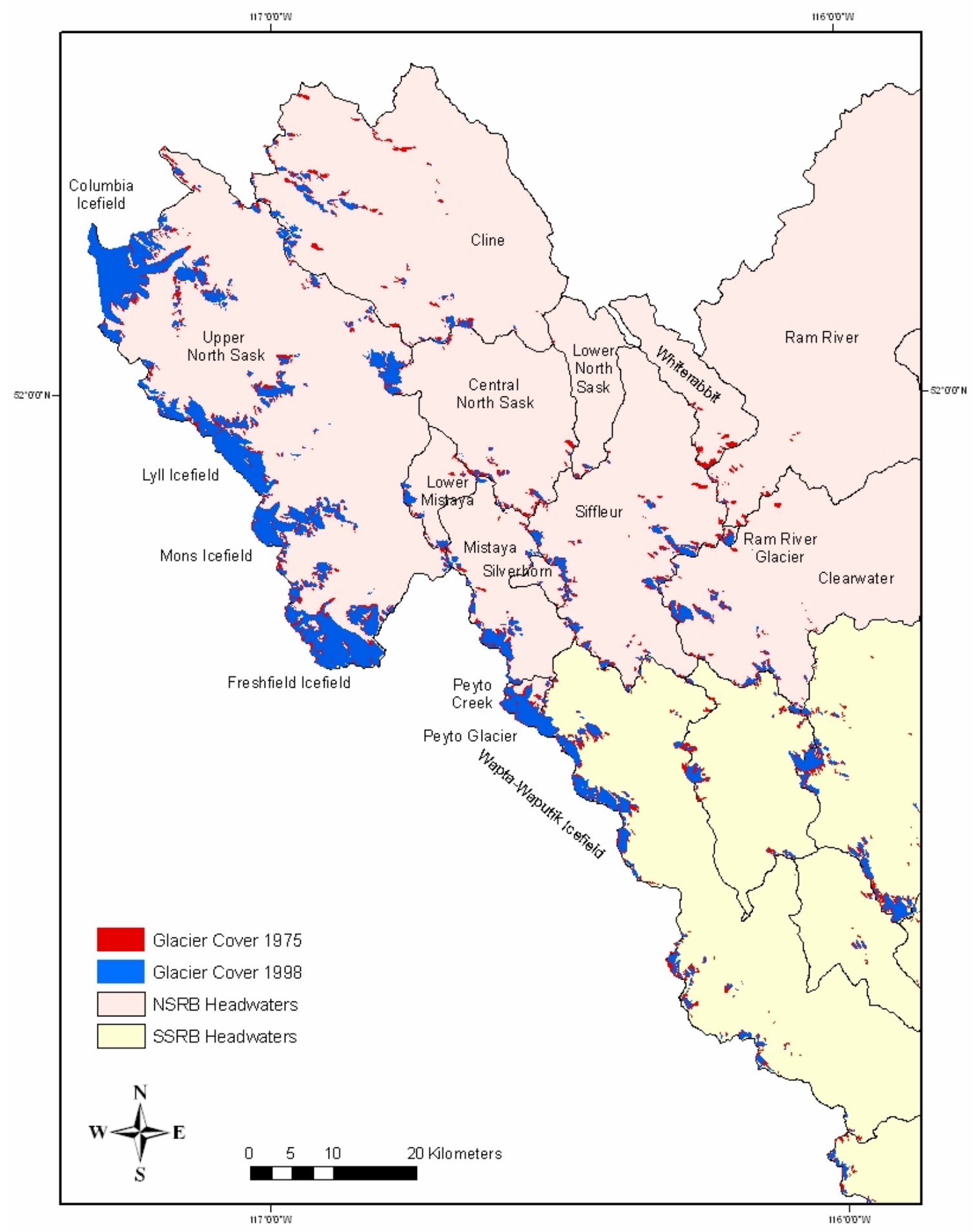

Figure 3.2 Glacier cover in the NSRB (1975 and 1998) (less Brazeau basin). Source: Data files from National Hydrology Research Centre, Saskatoon. 


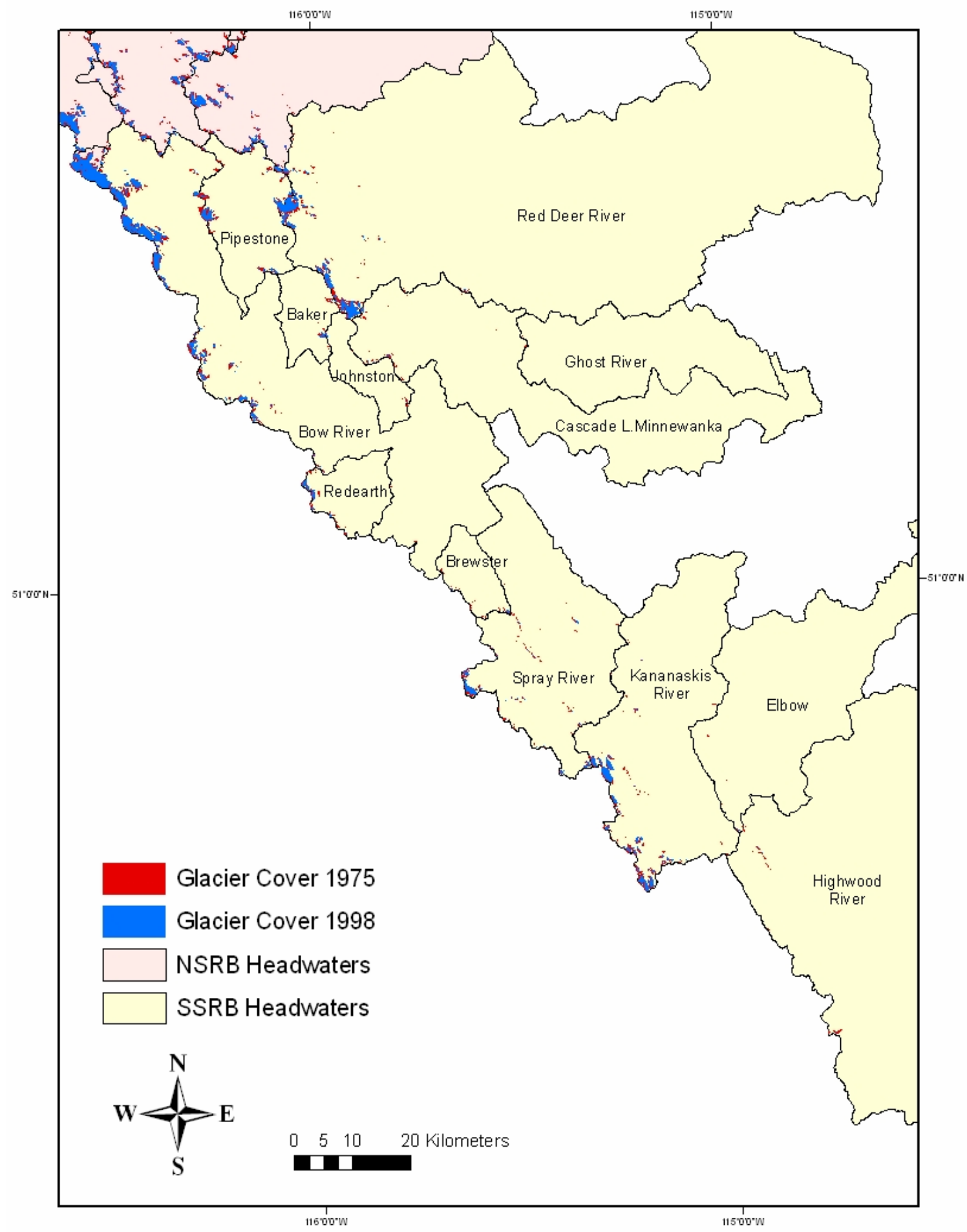

Figure 3.3 Glacier cover in the SSRB (1975 and 1998) (less Oldman basin). Source: Data files from National Hydrology Research Centre, Saskatoon. 
This thesis uses a variety of methods to estimate glacial impact and contribution to streamflow in a number of headwater basins as presented in the methodology chapter. Table 3.1 and 3.2 below list all the $\mathrm{N}$ and SSRB headwater basins and sub-basins that were examined. For each basin, the Water Survey of Canada (WSC) gauge identification number is given along with the time period of available streamflow data from the WSC archived hydrometric data sets, effective drainage area (local and cumulative) and the percentage glacier cover derived from the 1975 and 1998 Landsat imagery (Environment Canada WSC: HYDAT). It should be noted, however, that in some cases there are missing months, in particular winter months, and occasionally missing years of data between the time periods of available streamflow data indicated in the table. 
Table 3.1 Gauging station information and area-wise changes in the extent of glacier cover for subbasins of the NSRB headwaters (less Brazeau basin).

Source: Streamflow gauge data from Environment Canada WSC: HYDAT, and glacier data files from the National Hydrology Research Centre, Saskatoon.

\begin{tabular}{|c|c|c|c|c|c|c|}
\hline \multirow[t]{2}{*}{$\begin{array}{l}\text { Gauge } \\
\text { ID No }\end{array}$} & \multirow[t]{2}{*}{ Station Gauge Name } & \multicolumn{2}{|c|}{ Sub- Basin Area km² } & \multirow[t]{2}{*}{ Gauge record } & \multicolumn{2}{|c|}{$\begin{array}{l}\% \text { Glacier } \\
\text { Cover }\end{array}$} \\
\hline & & Local & Cumulative & & 1975 & 1998 \\
\hline 05DA001 & $\begin{array}{l}\text { Whiterabbit Creek near } \\
\text { Wilson's Ranch }\end{array}$ & 119.07 & 119.07 & $1915-1917$ & 3.4 & 0.05 \\
\hline 05DA002 & $\begin{array}{l}\text { Siffleur River near the } \\
\text { mouth }\end{array}$ & 514.74 & 514.74 & $\begin{array}{l}1915-1917 \\
1975-1996\end{array}$ & 5.3 & 2.9 \\
\hline 05DA003 & $\begin{array}{l}\text { North Saskatchewan River } \\
\text { at Wilson's Ranch }\end{array}$ & 121.21 & 2559.00 & 1916-1917 & 13.3 & 10.9 \\
\hline 05DA004 & Cline River near the mouth & 821.59 & 821.59 & $1915-1918$ & 3.5 & 1.8 \\
\hline 05DA005 & $\begin{array}{l}\text { Mistaya River near the } \\
\text { mouth }\end{array}$ & 67.40 & 315.42 & $\begin{array}{l}1915-1917 \\
1967-1969\end{array}$ & 12.0 & 9.6 \\
\hline 05DA006 & $\begin{array}{l}\text { North Saskatchewan River } \\
\text { at Saskatchewan Crossing }\end{array}$ & 1287.09 & 1287.09 & 1951-1969 & 20.2 & 17.6 \\
\hline 05DA007 & $\begin{array}{l}\text { Mistaya River near } \\
\text { Saskatchewan Crossing }\end{array}$ & 204.31 & 248.02 & $1951-2006$ & 13.5 & 10.8 \\
\hline 05DA008 & $\begin{array}{l}\text { Peyto Creek at Peyto } \\
\text { Glacier }\end{array}$ & 22.69 & 22.69 & 1967-1977 & 62.6 & 52.8 \\
\hline 05DA009 & $\begin{array}{l}\text { North Saskatchewan River } \\
\text { at Whirlpool point }\end{array}$ & 320.55 & 1923.06 & 1970-2006 & 16.2 & 13.7 \\
\hline 05DA010 & $\begin{array}{l}\text { Silverhorn Creek near the } \\
\text { mouth }\end{array}$ & 21.03 & 21.03 & 1971-2006 & 4.1 & 2.4 \\
\hline 05DB003 & $\begin{array}{l}\text { Clearwater River above } \\
\text { Limestone Creek }\end{array}$ & 1342.76 & 1342.76 & 1959-1992 & 1.3 & 0.8 \\
\hline 05DC006 & Ram River near the mouth & 1502.51 & 1853.53 & $1967-2007$ & 0.3 & 0.1 \\
\hline 05DC007 & $\begin{array}{l}\text { North Saskatchewan River } \\
\text { below Tershishner Creek }\end{array}$ & 398.38 & 3898.04 & 1954-1968 & 9.6 & 7.5 \\
\hline 05DC008 & Ram River at Ram Glacier & 3.71 & 3.71 & 1968-1974 & 54.7 & 33.7 \\
\hline 05DC011 & $\begin{array}{l}\text { North Ram River at } \\
\text { Forestry Road }\end{array}$ & 347.31 & 347.31 & $1975-2007$ & 0.0 & 0.0 \\
\hline
\end{tabular}


Table 3.2 Gauging station information and area-wise changes in the extent of glacier cover for subbasins of the SSRB headwaters (less Oldman basin).

Source: Streamflow gauge data from Environment Canada WSC: HYDAT, and glacier data files from the National Hydrology Research Centre, Saskatoon.

\begin{tabular}{|c|c|c|c|c|c|c|}
\hline \multirow{2}{*}{$\begin{array}{l}\text { Gauge } \\
\text { ID No }\end{array}$} & \multirow[t]{2}{*}{ Station Gauge Name } & \multicolumn{2}{|c|}{ Sub- Basin Area km² } & \multirow[t]{2}{*}{ Gauge record } & \multicolumn{2}{|c|}{$\begin{array}{l}\text { \% Glacier } \\
\text { Cover }\end{array}$} \\
\hline & & Local & Cumulative & & 1975 & 1998 \\
\hline 05BA001 & Bow River at Lake Louise & 6.11 & 422.21 & $\begin{array}{l}1910-1919 \\
1964-2007\end{array}$ & 9.4 & 7.3 \\
\hline 05BA002 & $\begin{array}{l}\text { Pipestone River near Lake } \\
\text { Louise }\end{array}$ & 306.43 & 306.43 & $\begin{array}{l}1912-1920 \\
1973-1977 \\
1984-2006\end{array}$ & 4.3 & 2.2 \\
\hline 05BA003 & $\begin{array}{l}\text { Bath Creek near Lake } \\
\text { Louise }\end{array}$ & 68.98 & 68.98 & $1913-1920$ & 14.3 & 10.2 \\
\hline 05BA004 & $\begin{array}{l}\text { Louise Creek near Lake } \\
\text { Louise }\end{array}$ & 25.43 & 25.43 & 1913-1918 & 20.8 & 12.4 \\
\hline 05BA005 & $\begin{array}{l}\text { Bow River above Bath } \\
\text { Creek }\end{array}$ & 67.91 & 414.98 & $1962-1963$ & 7.2 & 5.8 \\
\hline 05BA006 & $\begin{array}{l}\text { Johnston Creek near the } \\
\text { mouth }\end{array}$ & 122.95 & 122.95 & $1973-1976$ & 0.6 & 0.2 \\
\hline 05BA007 & $\begin{array}{l}\text { Baker Creek near the } \\
\text { mouth }\end{array}$ & 125.80 & 125.80 & $1973-1976$ & 1.2 & 0.5 \\
\hline 05BA008 & $\begin{array}{l}\text { Bow River below Hector } \\
\text { Lake }\end{array}$ & 50.63 & 279.26 & $1973-1976$ & 10.6 & 8.6 \\
\hline 05BA009 & Bow Glacier outflow & 25.79 & 25.79 & $1973-1975$ & 33.6 & 28.1 \\
\hline 05BA010 & $\begin{array}{l}\text { Bow River above Hector } \\
\text { Lake }\end{array}$ & 164.20 & 189.99 & 1974-1975 & 7.6 & 5.4 \\
\hline 05BA011 & $\begin{array}{l}\text { Balfour Creek near the } \\
\text { mouth }\end{array}$ & 38.64 & 38.64 & $1974-1975$ & 38.5 & 34.3 \\
\hline 05BB001 & Bow River at Banff & 808.09 & 2204.61 & $1909-2007$ & 3.4 & 2.2 \\
\hline 05BB003 & $\begin{array}{l}\text { Forty Mile Creek near } \\
\text { Banff }\end{array}$ & 132.92 & 132.92 & $\begin{array}{l}1912-1919 \\
1946-1947 \\
1972-1977\end{array}$ & 0.1 & 0.01 \\
\hline 05BB004 & Brewster Creek near Banff & 110.15 & 110.15 & 1971-1996 & 1.2 & 0.3 \\
\hline 05BB005 & $\begin{array}{l}\text { Redearth Creek near the } \\
\text { Mouth }\end{array}$ & 150.61 & 150.61 & 1973-1996 & 2.9 & 1.6 \\
\hline 05BC001 & Spray River at Banff & 229.63 & 750.43 & $1910-2007$ & 1.3 & 0.7 \\
\hline 05BC002 & $\begin{array}{l}\text { Spray River near Spray } \\
\text { Lakes }\end{array}$ & 362.16 & 362.16 & $\begin{array}{l}1915-1922 \\
1924-1939\end{array}$ & 2.3 & 1.3 \\
\hline $05 \mathrm{BC} 003$ & $\begin{array}{l}\text { Spray Creek at Spray } \\
\text { Lakes }\end{array}$ & 117.86 & 117.86 & 1914-1939 & 0.5 & 0.3 \\
\hline 05BC007 & $\begin{array}{l}\text { Spray Reservoir Spillway } \\
\text { near Canyon Dam }\end{array}$ & 1.25 & 481.27 & 1974 & 1.9 & 1.0 \\
\hline 05BC008 & $\begin{array}{l}\text { Goat Creek at Banff Park } \\
\text { Boundary }\end{array}$ & 39.54 & 39.54 & 1976-2006 & 0.00 & 0.00 \\
\hline 05BD005 & $\begin{array}{l}\text { Cascade River above Lake } \\
\text { Minnewanka }\end{array}$ & 451.84 & 451.84 & 1973-1996 & 0.6 & 0.1 \\
\hline 05BE004 & Bow River near Seebe & 76.69 & 4971.04 & $1923-2006$ & 2.2 & 1.4 \\
\hline 05BF002 & Kananaskis River above & 0.24 & 148.34 & 1931-1935 & 11.9 & 8.0 \\
\hline
\end{tabular}


Table 3.2 continued

\begin{tabular}{|c|c|c|c|c|c|c|}
\hline 05BF003 & $\begin{array}{l}\text { Lower Lake } \\
\text { Kananaskis River above } \\
\text { Pocaterra Creek }\end{array}$ & 2.77 & 358.83 & 1931-2006 & 6.1 & 3.8 \\
\hline 05BF004 & $\begin{array}{l}\text { Pocaterra Creek near } \\
\text { mouth }\end{array}$ & 63.01 & 63.01 & 1931-1941 & 0.2 & 0.0 \\
\hline 05BF008 & $\begin{array}{l}\text { Smith-Dorrien Creek near } \\
\text { mouth }\end{array}$ & 101.05 & 130.04 & $1932-1933$ & 2.9 & 1.5 \\
\hline 05BF009 & Lower Kananaskis Lake & 21.34 & 356.06 & $1969-2006$ & 6.1 & 3.9 \\
\hline 05BF010 & $\begin{array}{l}\text { Kananaskis River at outlet } \\
\text { of Lower Lake }\end{array}$ & 28.93 & 204.67 & $1932-1948$ & 8.8 & 5.8 \\
\hline 05BF011 & Boulton Creek near mouth & 27.40 & 27.40 & 1936-1941 & 0.8 & 0.1 \\
\hline $05 \mathrm{BF} 013$ & Mud Lake Diversion Canal & 29.00 & 29.00 & 1949-1992 & 4.7 & 4.0 \\
\hline 05BF021 & $\begin{array}{l}\text { Kananaskis River in canal } \\
\text { below Upper Dam }\end{array}$ & 148.10 & 148.10 & 1933-1942 & 11.2 & 8.0 \\
\hline 05BF022 & $\begin{array}{l}\text { Kananaskis River at } \\
\text { Canyon above Lower Falls }\end{array}$ & 5.51 & 364.34 & 1933-1935 & 5.9 & 3.8 \\
\hline $05 \mathrm{BF} 023$ & $\begin{array}{l}\text { Kananaskis River below } \\
\text { Ribbon Creek }\end{array}$ & 325.37 & 752.71 & $n / a$ & 3.0 & 1.8 \\
\hline 05BG002 & $\begin{array}{l}\text { Ghost River near Black } \\
\text { Rock Mountain }\end{array}$ & 209.77 & 209.77 & 1941-1993 & 0.04 & 0.00 \\
\hline 05BJ006 & $\begin{array}{l}\text { Elbow River above Elbow } \\
\text { Falls }\end{array}$ & 307.89 & 438.08 & 1967-1995 & 0.1 & 0.03 \\
\hline 05BJ009 & $\begin{array}{l}\text { Little Elbow River above } \\
\text { Nihahi Creek }\end{array}$ & 130.19 & 130.19 & 1978-1994 & 0.1 & 0.01 \\
\hline 05BL018 & Sheep River at Buck Ranch & 453.78 & 453.78 & 1950-1969 & 0.1 & 0.01 \\
\hline 05BL019 & $\begin{array}{l}\text { Highwood River at } \\
\text { Diebel's Ranch }\end{array}$ & 475.70 & 773.54 & $1950-2007$ & 0.2 & 0.01 \\
\hline 05BL021 & $\begin{array}{l}\text { Highwood River below } \\
\text { Picklejar Creek }\end{array}$ & 132.39 & 132.39 & 1966-1985 & 0.4 & 0.04 \\
\hline 05BL022 & $\begin{array}{l}\text { Cataract Creek near } \\
\text { Forestry Road }\end{array}$ & 165.45 & 165.45 & 1966-2006 & 0.0 & 0.0 \\
\hline 05CA003 & $\begin{array}{l}\text { Deer Creek (Main Stem) } \\
\text { near Sundre }\end{array}$ & 5.58 & 5.58 & 1966-1995 & 0.0 & 0.00 \\
\hline 05CA004 & $\begin{array}{l}\text { Red Deer River above } \\
\text { Panther River }\end{array}$ & 941.30 & 941.30 & 1967-2006 & 3.1 & 2.1 \\
\hline 05CA008 & $\begin{array}{l}\text { Red Deer River at Forestry } \\
\text { Road }\end{array}$ & 713.89 & 1655.19 & $1970-1978$ & 1.8 & 1.2 \\
\hline 05CA009 & $\begin{array}{l}\text { Red Deer River below } \\
\text { Burnt Timber Creek }\end{array}$ & 582.65 & 2243.42 & 1973-2006 & 1.3 & 0.9 \\
\hline
\end{tabular}




\section{Chapter 4}

\subsection{Methodology}

\subsection{Glacial Impact on Streamflow in the $\mathrm{N}$ and SSRB Headwaters}

Prior to quantifying the glacier contribution to streamflow, the impact of glaciers on flow in the $\mathrm{N}$ and SSRB headwaters was assessed by a comparison of observed streamflow hydrographs from glacierised and non-glacierised basins obtained from the Water Survey of Canada database, HYDAT (Environment Canada WSC: HYDAT). Glacierised and nonglacierised basins were selected from Tables 3.1 and 3.2 with a common period of record. The time period that allowed comparing the greatest number of basins ( 21 basins) over a long, continuous time period was identified as 1976-1992. Differences between the observed hydrographs in basins with and without glaciers in the summer months (June to October) were analysed by calculating the percentage streamflow each month contributed to the total June to October flow volume. This time period was chosen for hydrograph observation because glaciers contribute to streamflow varying amounts throughout these months. Whether the glacier contributes significant amounts in June and October depends on the weather each year. The coefficient of variation $(C V)$ of the discharge for the time period, both for the annual dataset and for the July to September dataset was calculated, and a comparison of results from glacierised and non-glacierised basins made. The selection of the July to September time period was chosen for calculating the $C V$ discharge because this is when the majority of glacier contribution occurs in this region (e.g. Demuth et al. 2008). Streamflow $C V$ was calculated using the equation: 
Coefficient of Variation $=\underline{\text { Standard Deviation of dataset }}$

Mean of dataset

It is assumed that two basins with the same glacial conditions will have the same streamflow coefficient of variation, thus differences in streamflow $C V$ are attributed to the presence of glaciers in a basin. This is likely a poor assumption since other factors such as differences in land cover can affect streamflow $C V$. It is, however, thought that the impact of glaciers on streamflow $C V$ is sufficiently significant that differences between glacierised and non-glacierised basins can be taken as evidence of the regulatory impact of glaciers on streamflow (Fountain and Tangborn 1985, Chen and Ohmura 1990b, Moore 1992, Fleming and Clarke 2005). The main limitation to this approach was the lack of available observed streamflow data which restricted the number of basins that could be analysed.

\subsection{Hydrological Model WATFLOOD}

There are very few regional scale distributed hydrological models that incorporate glaciers and that could be used to evaluate a basin domain as large as the Saskatchewan River basin. WATFLOOD (Kouwen, 1988) is one such model, and has been previously operationalised for use on the NSRB by Demuth and Pietroniro (2003). Since then, it has also been applied to the SSRB, and updated with the more accurately derived glacier cover from Landsat Imagery for 1975 and 1998 (Pietroniro et al. internal report). Initial calibration of melt factors, parameterisation and sensitivity analysis has also been completed (Pietroniro et al. internal report). The work of this thesis includes updating the WATFLOOD files to new formats, extending the time series files from 1990 to 2005, running the model with the 1975 and 1998 glacier cover, and analysing the results. For reference purposes, a description of the model, its 
operationalisation for use on the North and South Saskatchewan River basins, and the initial calibration and sensitivity analysis conducted is included in this chapter.

\subsubsection{Description of the hydrologic model}

\subsubsection{Processes within WATFLOOD}

WATFLOOD is a deterministic, semi-distributed and unsteady flow model (Kouwen et al. 1993), which represents the physical processes using empirical and conceptual equations (Bingeman et al. 2006). WATFLOOD is designed for both short-term flood forecasting and long-term hydrological simulation using distributed precipitation data, and has been under continuous development since 1972 (Kouwen 2006). The model emphasizes those processes most important during periods of significant runoff (Pietroniro et al. internal report), including interception, infiltration, evaporation, snow accumulation and ablation, interflow, recharge, baseflow, and overland and channel routing (Kouwen et al.1993, Kouwen 2006). The processes involved in modelling runoff are shown in Figure 4.1. 


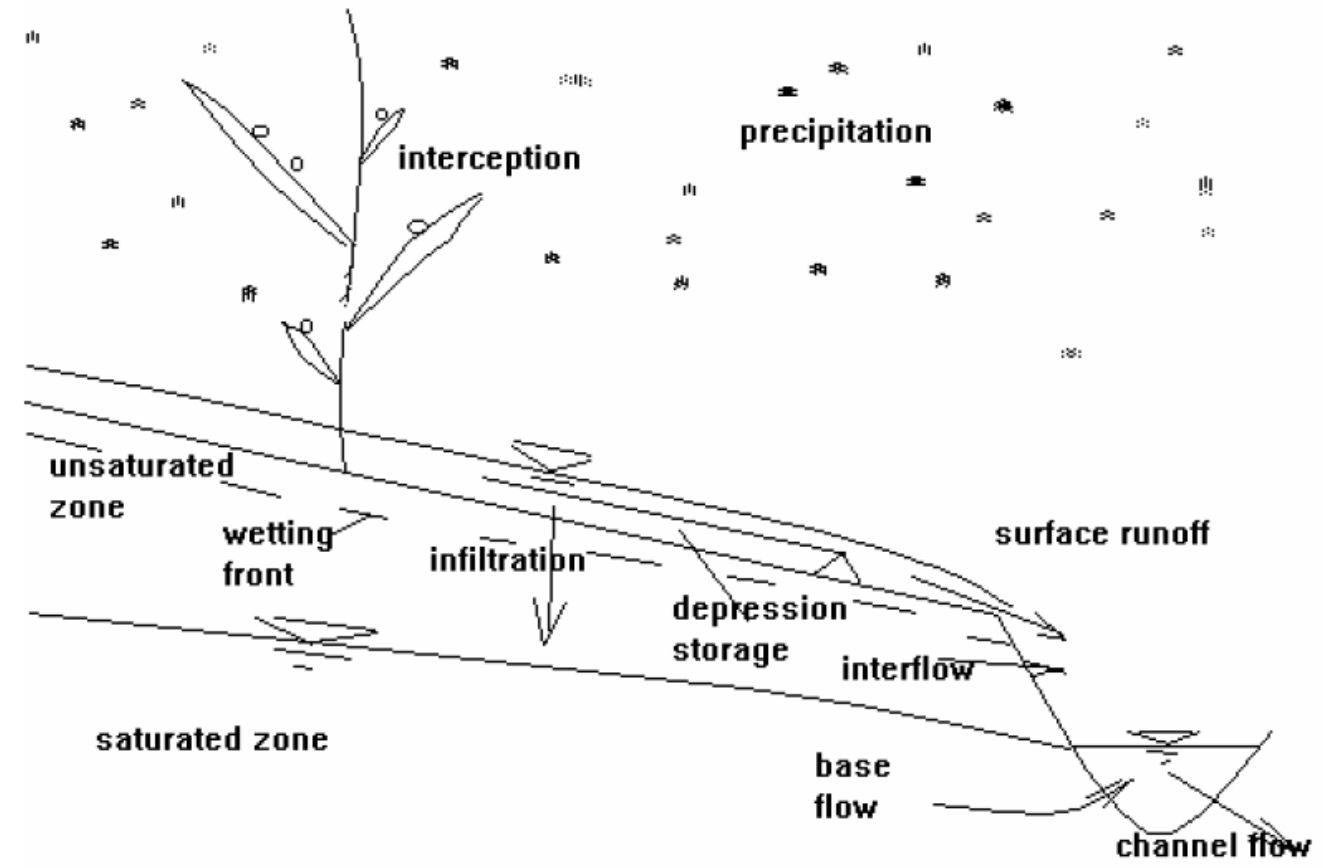

Figure 4.1 Schematic of the runoff algorithm Source: Kouwen 2006, section 2.1 p213.

The modelling process starts with the input of precipitation, and the processes shown in Figure 4.1 are described in detail in the WATFLOOD users manual (Kouwen 2006). The equations used to represent these processes in WATFLOOD are summarised in Table 4.1. 
Table 4.1 Equations used to represent the processes in WATFLOOD. Information from: Kouwen 2006

\begin{tabular}{ll}
\hline Process & Equation \\
\hline $\begin{array}{l}\text { Interception } \\
\text { Infiltration }\end{array}$ & $\begin{array}{l}\text { Linsley et al. (1949) } \\
\text { Philip (1954) modified from Green-Ampt equation (Green } \\
\text { and Ampt 1911) }\end{array}$ \\
Surface storage & $\begin{array}{l}\text { ACSE Manual of Engineering Practice No. 37 (1969) gives } \\
\text { values of retention for different surface types }\end{array}$ \\
Evapotranspiration & $\begin{array}{l}\text { Hargreaves (Hargreaves and Samani 1982) model was used } \\
\text { in this study. Other options: Priestley and Taylor (1972) or } \\
\text { estimation from published values. }\end{array}$ \\
$\begin{array}{l}\text { Snow accumulation } \\
\text { and ablation }\end{array}$ & $\begin{array}{l}\text { Temperature index algorithm (Anderson 1973) } \\
\text { Interflow }\end{array}$ \\
$\begin{array}{l}\text { Sroundwater } \\
\text { recharge }\end{array}$ & $\begin{array}{l}\text { calculation } \\
\text { Storage-discharge relationship, with interflow calculation } \\
\text { (calculated simultaneously to interflow) }\end{array}$ \\
Base flow & $\begin{array}{l}\text { Manning's storage routing } \\
\text { Initial flow from measured stream hydrograph. Exponential } \\
\text { depletion function applied }\end{array}$ \\
Channel routing & $\begin{array}{l}\text { Storage routing technique using the continuity equation } \\
\text { related to Manning's formula }\end{array}$ \\
\hline
\end{tabular}

Spatial variability of basin characteristics in most distributed models is represented using elements called hydrologic response units (HRU's). HRU's are defined as landscape units in which the hydrological processes can be described for calculation by unique sets of parameters, variables, and both horizontal and vertical fluxes (Pomeroy et al. 2007). HRU's can be small scaled, such as a hillslope segment, or large scaled, such as an entire sub-basin, though typically HRU's correspond to the biophysical landscape unit scale such as hillslope, valley bottom or agricultural field (Pomeroy et al. 2007). WATFLOOD differs by modelling the vertical component using the grouped response unit (GRU) approach in which each land cover class is assigned a unique set of parameters and different land cover classes are incorporated into a GRU. The hydrological processes of each land cover class are thus presented and parameterised 
identically within each grid, and the response is weighted according to the percentage of each land cover found in the GRU. The resulting outflow is then summed as a total for the GRU, in which each individual area is subject to the same meteorological conditions, and routed through the stream network (Kouwen et al. 1993). The size of the GRU grid elements are therefore determined by the resolution of the meteorological data or the detail required of the model output, since the land cover pixels within are grouped to deal with sub-grid hydrological heterogeneity. A schematic of the GRU approach is displayed in Figure 4.2, which shows a number of grouped response units each containing four land cover classes, with the summation of runoff from each unit routed to the next. The result of this approach is that there are very few watershed specific parameters because the majority are land cover based, reducing the need for model calibration and making it more easily applicable to large, regional scale basins such as the $\mathrm{N}$ and SSRB. Consequently, it should be possible to readily transfer the model to other watersheds without re-calibration, though validation tests should be conducted and the results tend to degrade with distance from the calibration watershed (Bingeman et al. 2006, Kouwen et al. 1993). 


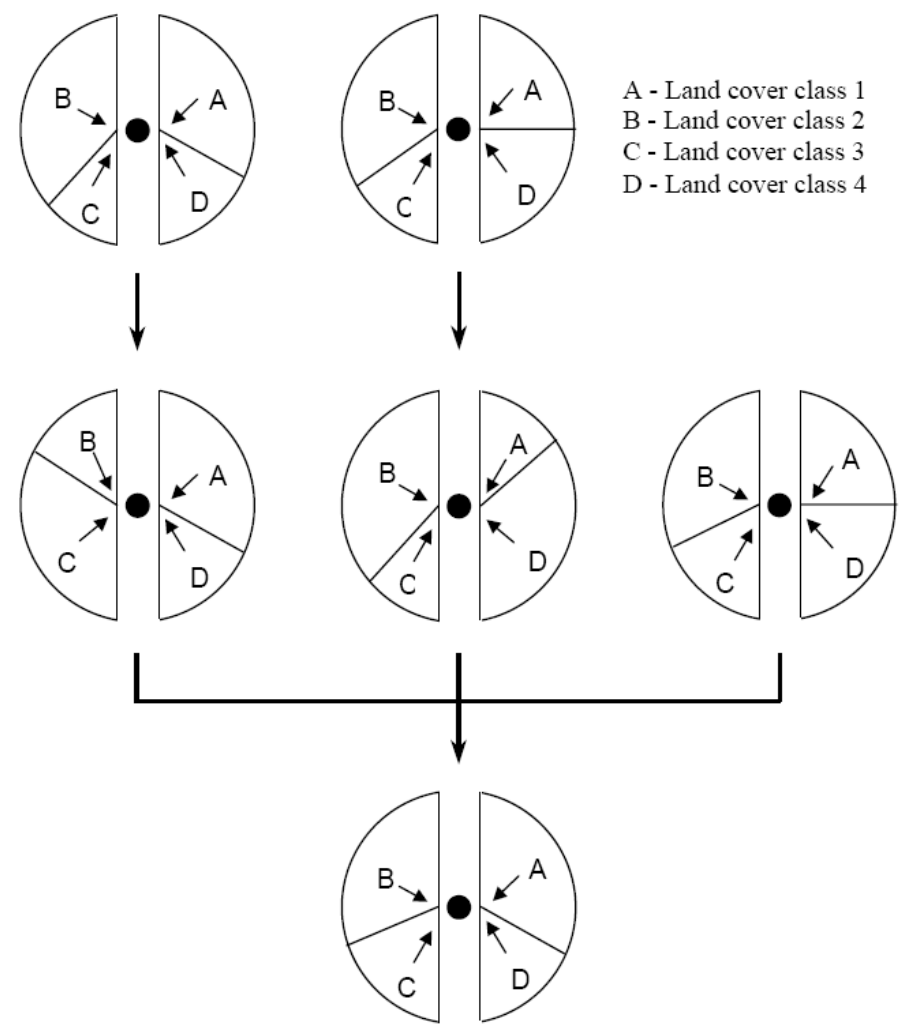

Figure 4.2 Schematic of the GRU approach and routing scheme.

Source: Kouwen 2006, section 1.2 p17

\subsubsection{Modelling glacier runoff}

Glacier modelling studies use either mass balance models, based upon glacier mass balance measurements, or hydrological snowmelt models, calibrated with streamflow discharge measurements (Jóhannesson et al. 1995). This study uses a hydrological model to simulate discharge downstream from the glacier. The lack of mass balance data on glaciers in the study area prevents the use of a mass balance model to estimate glacier runoff. Ablation models may be divided into three main categories (Braithwaite et al. 1992): degree-day models, precipitationcorrected degree-day models, and surface energy balance models. A degree-day model (e.g. Singh et al. 2000) is based on a simple conceptual equation. The model will generally perform calculations on a daily basis where the melt rate is the product of a melting factor and the 
difference between the current temperature and the base temperature at which melting begins. The melting factor changes according to the surface type (e.g. ice or snow) to account for differences in albedo. The precipitation-corrected degree day model (e.g. Power 1985) uses the degree-day model on clear days and increases the amount of melt on rainy days due to the addition of heat from rain. Degree-day models have substantial limitations in that they simplify the complex processes involved in snow and ice melt, and defining accurate melting factors is problematic. Whilst they appear to work well over long time periods, their accuracy decreases with increased temporal resolution, and spatial variability cannot be modelled accurately due to the variability of melt rates (Hock 2003), partially dictated in the degree-day equation by the melting factor which generally remains constant in models. Melting factors have considerable spatial and temporal variability in reality since they depend on the relative importance of the energy balance variables to melt, which varies with surface type (e.g. snow density and albedo) and weather (including variability influenced by shading, slope and aspect) (Hock 2003). This variability results in the lack of universal values for melting factors specific to a surface type (e.g. glacier ice), thus they need to be adjusted or treated as calibration parameters with reasonable limits, and even then a fixed value is problematic since melting factors vary temporally, even on a diurnal time scale (Hock 2003). The surface energy balance model (e.g. Arnold et al. 1996) is more physically based and a more accurate method of modelling melt. The model calculates the energy for melt as a residual of the surface energy balance, therefore requiring measurements of the net short-wave and net long-wave radiation fluxes and the sensible and latent turbulent heat fluxes.

Despite their limitations, degree-day models, or temperature index models, are used most often for melt modelling due to the wide availability of air temperature data, the relatively easy 
interpolation and forecasting possibilities of air temperature, and computational simplicity (Hock 2003). When modelling areas for which there is insufficient data to use a more accurate energy balance model, such as the N and SSRB, degree-day models are useful on the basis of the strong correlation that has been found between air temperature and several of the energy balance components. Typically, longwave atmospheric radiation is by far the most important heat source for melt and is highly affected by the air temperature, and in addition, global radiation and the sensible heat flux, which are the second and third most important heat sources for melt respectively, are also correlated with air temperature (Ohmura 2001). Due to the lack of sufficient data with which to use an energy balance model, as is the case in the vast majority of regional scale modelling studies, a degree-day model is used within WATFLOOD to model snow and ice melt in the N and SSRB.

\subsubsection{Modelling glacier runoff in WATFLOOD}

Snow-covered and snow-free areas are modelled separately in WATFLOOD, with the energy used to melt snow only applied to snow covered areas (Kouwen 2006). Snowcover depletion curves (SDCs) summarise the relationship between snow cover distribution and an average snow cover property. In this case, the curves provide the amount of snow covered area for a given depth of water equivalent for each land cover class (Pietroniro et al. internal report). WATFLOOD also has a snow redistribution algorithm for which an upper limit is set on the water equivalent for each land cover class based on field observations. For forests and glacier the upper limit is very high since a greater volume of snow accumulates here relative to barren areas and wetlands for which the limit is quite low. When snow accumulates beyond the limit for a class, the snow is redistributed to the nearest forest, if present in the grid, or class with a higher limit (Pietroniro et al. internal report). 
The following description of the snowmelt model in WATFLOOD is based on the WATFLOOD user's manual by Kouwen (2006) to which the reader is directed for more information. Snowmelt is modelled following a degree-hour approach, which is the degree-day method performed on an hourly time-step. The temperature index algorithm used in WATFLOOD is based on the National Weather Service River Flow Forecast system by Anderson (1973) and is given by:

$$
M=M F\left(T_{a}-T_{\text {base }}\right)
$$

Where :

$\mathrm{M} \quad=\quad$ Daily snowmelt depth $(\mathrm{mm})$

$\mathrm{MF} \quad=\quad$ Melting factor, rate of melt per degree per unit time $\left(\mathrm{mm}^{\circ} \mathrm{C}^{-1} \mathrm{~h}^{-1}\right)$

$\mathrm{T}_{\mathrm{a}}=\quad$ Air temperature $\left({ }^{\circ} \mathrm{C}\right)$

$\mathrm{T}_{\text {base }}=\quad$ Base temperature, temperature at which the snow begins to melt $\left({ }^{\circ} \mathrm{C}\right)$

In WATFLOOD MF was set at 0.1 and $\mathrm{T}_{\text {base }}$ was set at $0{ }^{\circ} \mathrm{C}$, determined by calibration to observed streamflow measurements (Pietroniro et al. internal report).

The general heat balance is divided into melt and non-melt phases. For the non-melt period, the snow can be either heating or cooling, depending on the temperature of the air and snowpack. This allows re-freezing of snow within the model. The snow cover heat deficit (mm water equivalent) gives a cumulative amount of heat required to warm the snowpack to the melting phase. The change in heat deficit is based on the difference between the antecedent temperature index (ATI) and the air temperature, as well as the addition of any precipitation. The change in heat of the snow surface $\left(\Delta \mathrm{H}_{\mathrm{s}}\right)$, when the air temperature is less than or equal to 
$0{ }^{\circ} \mathrm{C}$ during a time-step, is expressed as:

$$
\Delta \mathrm{H}_{\mathrm{s}}=\operatorname{NMF}\left(\text { ATI }-\mathrm{T}_{\mathrm{a}}\right)-\underline{\mathrm{S}}_{1} \underline{\mathrm{T}}_{\underline{\mathrm{a}}}
$$

Where:

$\Delta \mathrm{H}_{\mathrm{s}}=$ Change in heat deficit ( $\mathrm{mm}$ of water equivalent)

$\mathrm{NMF}=\quad$ Negative melt factor - rate of change in heat deficit based on air temperature per unit time $\left(\mathrm{mm}^{\circ} \mathrm{C}^{-1} \mathrm{~h}^{-1}\right)$

ATI $=$ Antecedent temperature index

$\mathrm{S}_{\mathrm{f}} \quad=\quad$ The amount of snow fallen per unit time represented as snow water equivalent (SWE) in $\mathrm{mm}$.

$\mathrm{T}_{\mathrm{a}} \quad=\quad$ Air temperature $\left({ }^{\circ} \mathrm{C}\right)$

More information on the antecedent temperature index, based on the transient heat flow equation for semi-infinite solids, can be found in Kouwen (2006) WATFLOOD users manual.

The WATFLOOD model incorporates glaciers as a distinct landclass. The model allows snow to accumulate on and melt from the glacier in the same way that snow accumulates on and melts from any other landclass. For glaciers, however, the exposed ice mass begins to melt after the snow has melted using the same temperature index algorithm, with the additional application of a glacier melt enhancement factor (gladjust) that increases the melt rate to account for the decrease of albedo between snow and ice. Different authors have calculated widely varying results for the increase in melt rate from snow to ice, even for the same glacier, and especially between clean ice and debris covered ice (Braithwaite 1995, Jóhannesson et al. 1995, Laumann and Reeh 1993, Vincent and Vallon 1997, Woo and Fitzharris 1992, Singh et al. 2000). For example, Hock (1999) found that hourly degree day factors on Storglaciären $\left(3 \mathrm{~km}^{2}\right.$ glacier in 
Sweden), computed from melt determined from a distributed energy balance model on a $30 \mathrm{~m}$ resolution grid, ranged from $0-16 \mathrm{~mm} \mathrm{~d}^{-1} \mathrm{~K}^{-1}$ for the same hour of the day. It is, however, unanimously found that the melt rate for an ice surface is greater than snow, with results from the authors listed above ranging from 1.3-2.8 times greater (Pietroniro et al. internal report). Kouwen (2006) suggests a value between 1.5 and 2.0 is appropriate for the glacier melt enhancement factor in WATFLOOD, and a value of 1.5 was determined by calibration to observed streamflow measurements for use in this study on the N and SSRB (Pietroniro et al. internal report).

\subsubsection{Routing glacier runoff}

After surface melt has been calculated, there are a large variety of methods to route the surface melt to the toe of the glacier. To do so in a physically-realistic manner requires modelling and linking different components; en-glacial storage and transport, sub-glacial drainage, and subsurface groundwater flow (e.g. Flowers and Clarke 2002). This is difficult since these processes occur below the glacier ice surface and are hard to observe, thus the majority of methods have resorted to simpler approaches, such as using a linear storage reservoir to hold back surface melt to account for storage within the glacier (Gottlieb 1980 and Loukas et al. 2000). Other methods include likening the glacier drainage system to a groundwater system and modelling surface melt runoff accordingly (Derikx 1973).

WATFLOOD uses a very simple routing technique. The glacier is assumed to be impervious, and runoff is calculated using Manning's equation in the same way that surface runoff is calculated for other land cover classes. In WATFLOOD, it is assumed that the drainage network extends into grids containing glaciers and water is routed instream from grid to grid. Since the glacier is impervious in the model, it is assumed that all the meltwater from the glacier 
enters the grid runoff. This routing technique is conceptual and simplifies complex processes; however, it is suitable for the regional-scale study of this thesis due to the severe lack of data on the numerous glaciers in the study area, preventing a more physically based approach.

\subsubsection{Setting up the WATFLOOD model for the North and South Saskatchewan}

\section{River basins}

Two separate modelling domains were developed for this study. The first is the North Saskatchewan River basin (NSRB) which includes the major tributaries in this basin. The second domain is the South Saskatchewan River basin (SSRB) which includes the major tributaries in the headwater region of the South Saskatchewan basin. Unfortunately the Brazeau River and Oldman River in the N and SSRB respectively were not included in the modelling domains created for WATFLOOD. The operationalisation of WATFLOOD was completed prior to this thesis and the following description is based on Demuth and Pietroniro (2003) and Pietroniro et al. (internal report) to which the reader is directed for a more detailed explanation.

\subsubsection{Generating the WATFLOOD physiographic files}

Firstly, a watershed object using EnSim Hydrologic (EnSim, CHC/NRC), which is a tool for visualization and analysis for hydrologic applications developed by the Canadian Hydraulic Centre (CHC) and the National Research Council (NRC), was created in order to generate the WATFLOOD map. A watershed object is a coherent collection of data concerning the physiographic features of the entire watershed being studied. It includes information about the topography, the channels and the extent of the watersheds within the study area (Demuth and Pietroniro 2003). This information is derived from data contained within a digital elevation map (DEM). A DEM, in the context of EnSim Hydrologic, is a georeferenced regular grid that carries 
a value for elevation at each vertex (Demuth and Pietroniro 2003). The contour and hydrography layers from digital 1:250 000 NTS map sheets were used to create the DEM, with the source data in raster format with each pixel covering an area 150 by $150 \mathrm{~m}$, thus creating a grid with $150 \mathrm{~m}$ resolution (Demuth and Pietroniro 2003). The final watershed object, showing the topography, channels and watershed outlines is shown in Figure 4.3. The study area was in UTM zone 11 and the datum was NAD 1983.

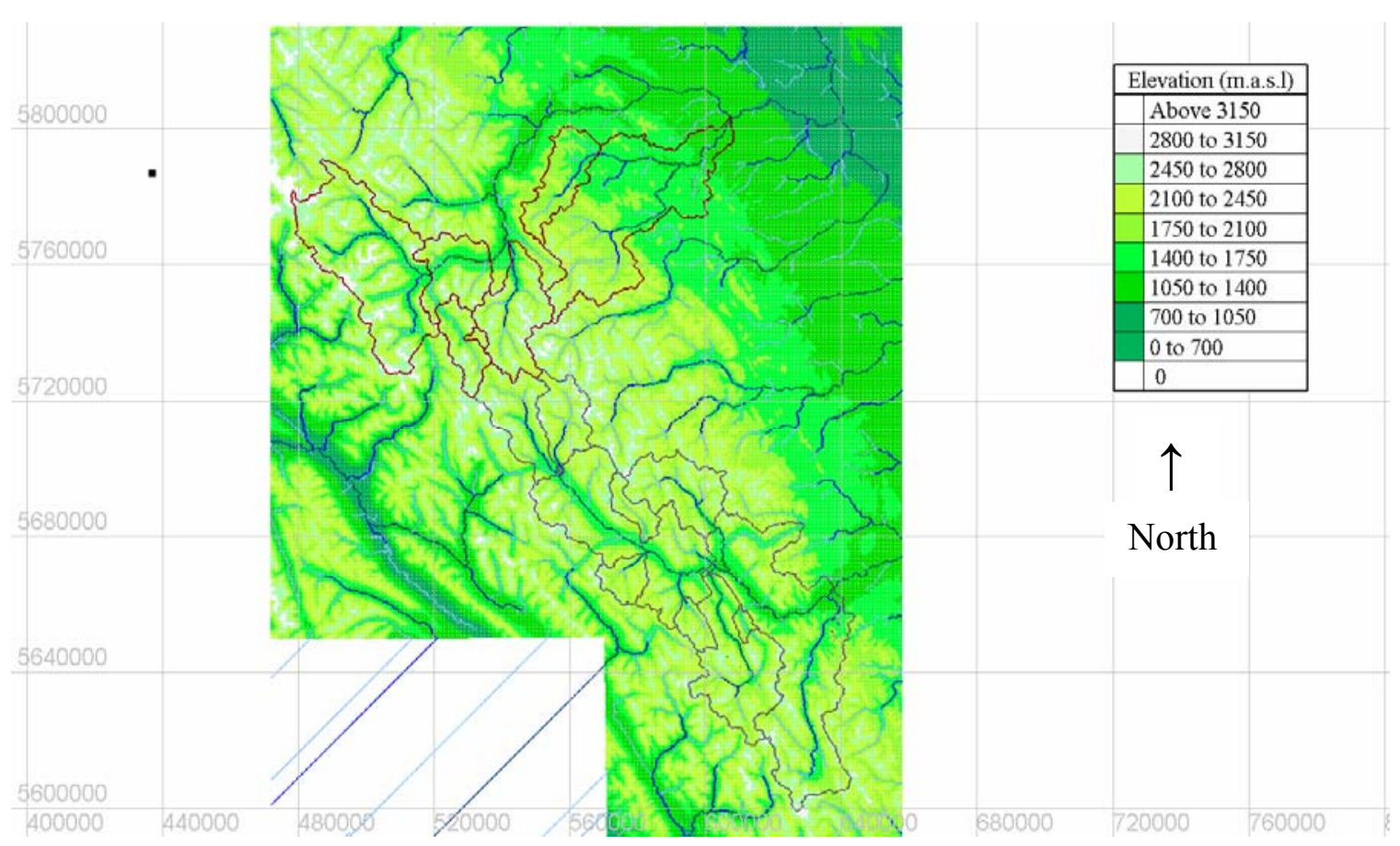

Figure 4.3 Completed EnSim watershed object in 2D showing the modelled basins in the NSRB (brown) and SSRB (grey) headwaters, and DEM elevation.

Source: Data files from National Hydrology Research Centre, Environment Canada.

From the information contained within the watershed object, EnSim Hydrologic (EnSim $\mathrm{CHC} / \mathrm{NRC}$ ) calculates automatically nearly all of the physiographic features required to create a WATFLOOD map. For the North Saskatchewan River basin, the WATFLOOD map cells (GRU elements) were 9 by $9 \mathrm{~km}$, with 23 cells running west-east and 15 cells running north-south. The 
UTM (zone 11, NAD 83) projection coordinates of the bottom left corner of the grid were 463000 East and 5704000 North. The WATFLOOD map cells (GRUs) for the South

Saskatchewan River basin were 5 by $5 \mathrm{~km}$, with 23 cells running west-east and 25 cells running north-south. For the SSRB, the UTM (zone 11, NAD 83) coordinates of the bottom left corner of the grid were 525000 East and 5613000 North. The map cell size was chosen to balance the number of computation units with the meteorological input data and water routing between grids. The map cell size differs between the N and SSRB to keep the number of computational units similar, and this difference does not affect glacier runoff since the meteorological input is the only variable that changes and there is insufficient data to warrant using a smaller grid size. When a map cell contains a watershed boundary, the areas divided by the boundary flow in different directions, but each cell can only have one value for drainage area and direction. The drainage area of each cell containing a watershed boundary was therefore altered to equal the area one side of the boundary, and the remaining area added to the adjacent cell that receives the flow from this area. This is demonstrated in Figure 4.4 below.

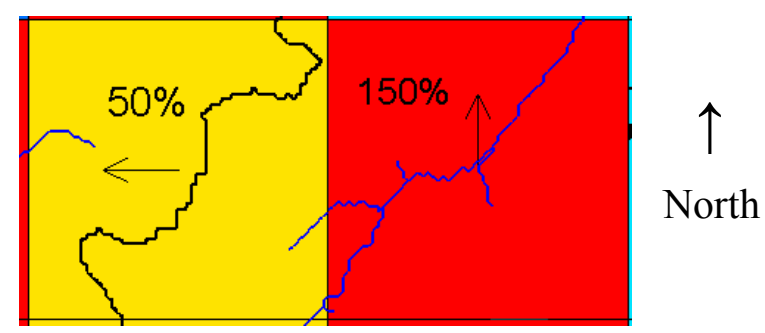

Figure 4.4 Adjacent cells with boundary flow in different directions. See text for explanation. Source: Demuth and Pietroniro (2003).

The watershed boundary, shown by the thick black line, divides the yellow cell approximately in half. Runoff, indicated by the blue river channels, from the left half flows to the west and runoff from the right half flows to the east, into the red cell. The yellow cell is, 
therefore, assigned a drainage direction of west and a drainage area of $50 \%$, representing the left half of the yellow cell. The area of the right half of the yellow cell is added to the red cell, giving the red cell a total of $150 \%$ (Demuth and Pietroniro 2003). The final WATFLOOD map for each domain is shown in Figure 4.5. 


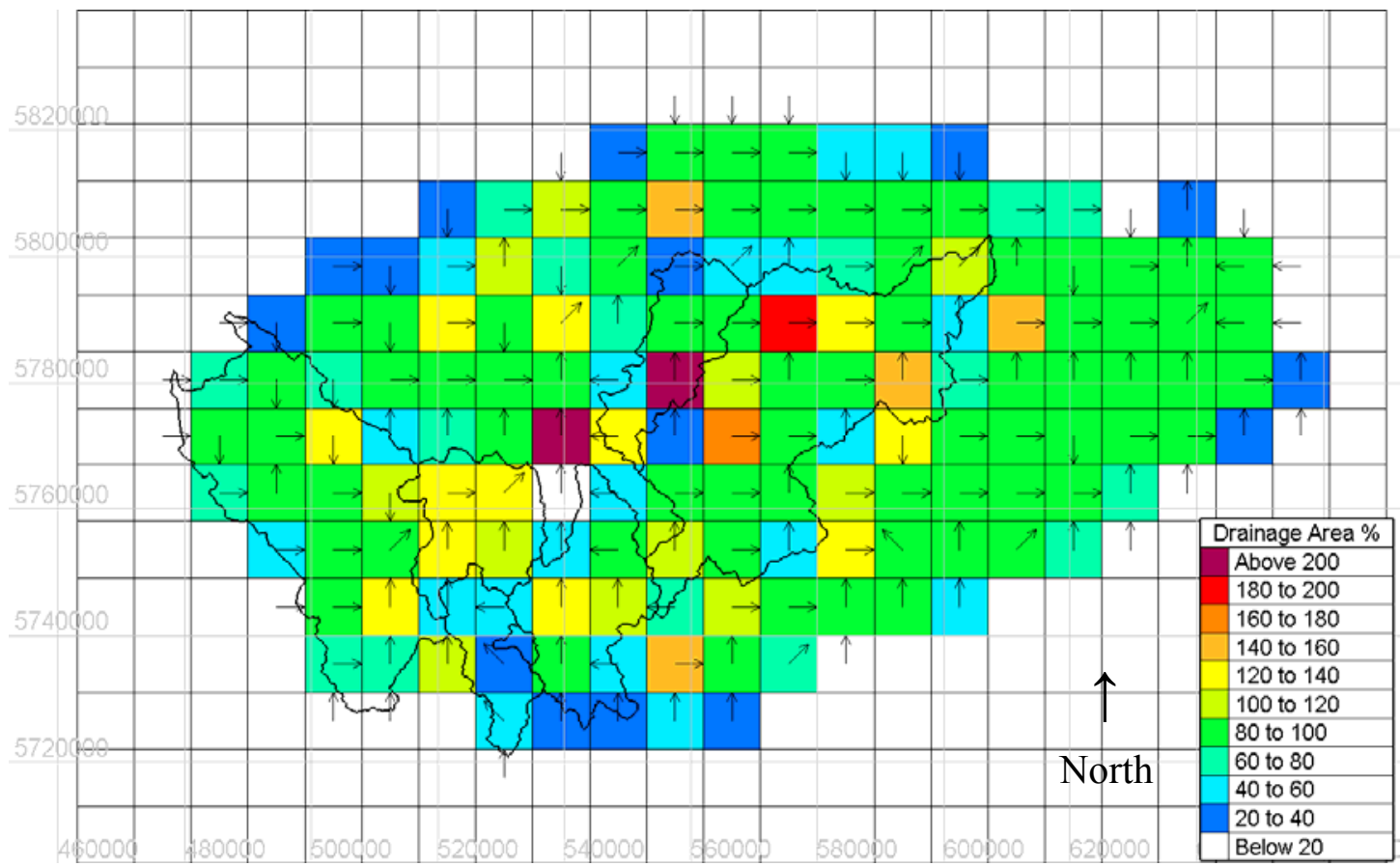

a)

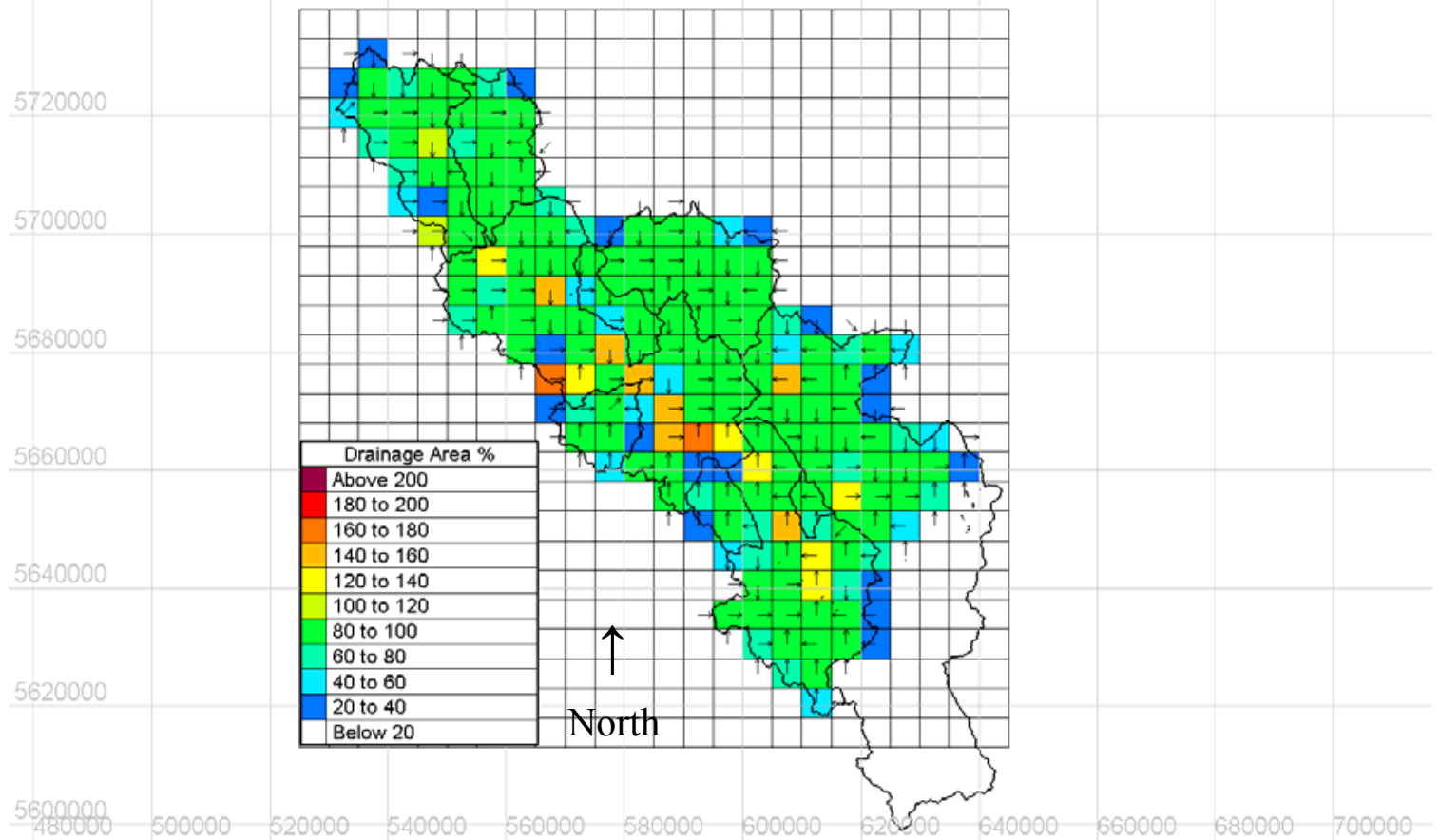

b)

Figure 4.5 WATFLOOD map file for the a) North and b) South Saskatchewan headwater basins displayed with EnSim Hydrologic, showing drainage area and drainage direction of each cell. Grid coordinates are in metres. Projection is UTM, Zone 11, NAD 1983 


\subsubsection{Land cover}

Nine classes were used to describe the land use: urban and rock, coniferous forest, deciduous forest, mixed forest, barren (short, sparse vegetation), wetland, crop, glacier, and water. The area in each cell is described in terms of the percentage cover of each of the nine land use classes. For example, the area of one map cell could consist of $73 \%$ coniferous forest, $11 \%$ mixed forest and $16 \%$ barren, with the remaining land use classes assigned values of $0 \%$ (Demuth and Pietroniro 2003). Land use was classified by the Canadian Centre for Remote Sensing (CCRS) from $1 \mathrm{~km}$ resolution NOAA satellite imagery, and the data obtained from the National Hydrology Research Centre (NHRC), Environment Canada, Saskatoon, after it had been formatted for use in WATFLOOD (Demuth and Pietroniro 2003). The map files were later updated with the glacier cover derived from Landsat imagery (section 3.3) producing different map files for the 1975 and 1998 glacier covers. The parameter values for eight of the nine land use classes were from NHRC. The values were the same as those used for a previous model of a system in northern Alberta, which had similar land-use classes. The values used for the parameters of the ninth land use class, urban and rock, were those in the standard WATFLOOD parameter file for the 'urban' class (Demuth and Pietroniro 2003).

\subsubsection{Hydrometric data}

Hydrometric data were obtained from the National Hydrology Research Centre (NHRC). Daily data $\left(\mathrm{m}^{3} \mathrm{~s}^{-1}\right)$ had been extracted from HYDAT (Environment Canada WSC: HYDAT), with records available to 2006/7. Missing data had been filled in using linear interpolation for gaps of less than 10 days, and interpolation and normalised data for larger gaps (Demuth and Pietroniro 2003). Continuous streamflow data files were required to calibrate the model. 


\subsubsection{Meteorological data}

Meteorological data were also obtained from NHRC. They had been extracted from the Environment Canada climate data archives and consisted of daily values for temperature (minimum, maximum, and mean) in degrees Celsius, and precipitation (rain, snowfall, and total) in $\mathrm{mm}$ for rain and total precipitation, and $\mathrm{cm}$ for snowfall (Demuth and Pietroniro 2003). The meteorological stations used to obtain the data were Banff, Golden, Jasper, Lake Louise and Rocky Mountain House (Figure 4.6).

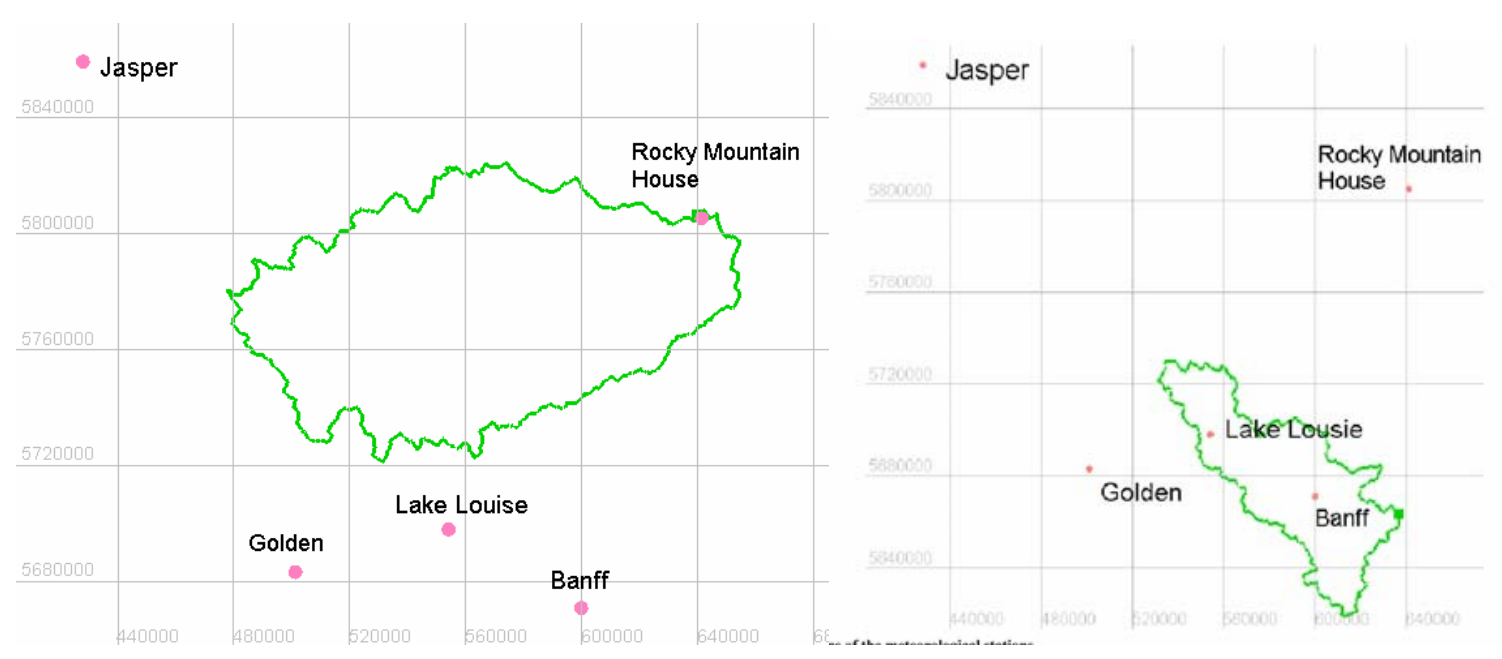

a)

b)

Figure 4.6 Locations of the meteorological stations in relation to the a) NSRB and b) SSRB headwater regions. Grid co-ordinates are in metres. Projection is UTM, Zone 11, NAD 83. Source: Demuth and Pietroniro 2003

\subsubsection{Precipitation}

From the available precipitation data, total precipitation was used in setting up the model. Climate stations that had daily precipitation records for more than 5 years during the period 1961-1990, for which WATFLOOD was initially operationalised, were identified. Because of the remoteness of the mountainous terrain, most of the climate data are recorded at lower 
elevations, particularly in the winter months when the few high terrain stations are closed (Pietroniro et al. internal report). The vertical precipitation gradient was examined by correlating monthly precipitation values and station elevation. Summer precipitation showed considerable dispersion and elevation-precipitation correlation for the eastern slopes of the Rocky Mountains basins was weak (Pietroniro et al. internal report). This is likely because much of the summer convective precipitation occurs in a south westerly flow which produces a rain shadow effect in the immediate lee of the mountains, while precipitation is enhanced on the south-facing slopes of the hills. Thus, there is a precipitation maximum occurring at an elevation of approximately $1500 \mathrm{~m}$. The average summer precipitation gradient was estimated to be $1.2 \mathrm{~mm}$ per $1000 \mathrm{~m}$ to an elevation of $1500 \mathrm{~m}$, and no gradient was assumed for higher elevations. Snowfall was more highly correlated to elevation but because there is a lack of high-terrain stations, some extrapolation was necessary to distribute snowfall for the highest elevations. The gradient applied for snowfall was $2.0 \mathrm{~cm}$ water equivalent per $1000 \mathrm{~m}$. The WATFLOOD model calculated whether the precipitation was rain or snow based on the air temperature.

To distribute precipitation hourly, since WATFLOOD operates on an hourly basis and only daily meteorological data were available, a daily-hourly disaggregation technique was developed. The daily precipitation data were entered in the first hour, and the other 23 hours were entered as missing data. Subsequently, precipitation was distributed over the day using a built-in routine within WATFLOOD, instead of all of the precipitation occurring in the first hour. A minimum precipitation of $0.5 \mathrm{~mm}$ per hour was chosen. Thus, if there were $3 \mathrm{~mm}$ of precipitation in a day, the model would rain/snow for 6 hours at $0.5 \mathrm{~mm}$ each hour, and there would be no precipitation for the rest of the day. If there was more than $12 \mathrm{~mm}$ of precipitation 
in a day, the precipitation would be divided by 24 and it would rain or snow an even amount all day long (Demuth and Pietroniro 2003, Pietroniro et al. internal report). Whilst this will produce unrealistic hourly precipitation measurements, this thesis is concerned with modelled streamflow output on a monthly average time scale as opposed to hourly results thus it is assumed significant errors are averaged out.

\subsubsection{Temperature}

Daily maximum and minimum temperatures were used instead of daily means. Stations with complete daily minimum and maximum temperatures between 1961 and 1990 were utilised in a temperature gridding process that used elevation and linear interpolation between the daily maxima and minima temperature to provide lapse rate corrected (to correct for the low altitude of the meteorological stations) and diurnally varying hourly temperatures. It was decided to interpolate the maximum and minimum temperatures to create three-hourly temperatures, and create a reasonable diurnal variation of temperature. The minimum temperature was assumed to occur at midnight and the maximum temperature was assumed to occur at noon (Pietroniro et al. internal report).

The same processes were applied to those stations with available temperature and precipitation data from 1990-2005 to extend the time series files to 2005 .

\subsubsection{Initial calibration, parameter estimation and sensitivity analysis of}

\section{WATFLOOD}

The WATFLOOD model has a series of tuning parameters that are landscape based. These parameters can be divided into vertical water budget parameters and routing parameters. The first deal primarily with the vertical and lateral transfer of water within each land cover unit 
and are modelled by conceptual equations similar to other hydrological models (Bingeman et al. 2006). The latter deal with grid cell based dynamics generally determined by physically based equations and include important and sensitive parameters such as channel roughness (Pietroniro et al. internal report). Where possible, these parameters describing the runoff-routing processes are assigned standard well known values, but those that cannot be predicted are fitted using a pattern search optimisation technique (Kouwen 2006). Physically definable limits drawn from textbooks and experience within the model have been determined and restrict the range of possible parameter values for calibration (Bingeman et al. 2006). To date, the sensitivity analysis by Pietroniro et al. (internal report) has focused on only the snow and ice melt parameterisation and the routing parameters. This initial evaluation of WATFLOOD used the NTS derived glacier cover and focused on the months of August to October which were thought to be the time period in which the majority of glacier runoff occurs. It has since been determined from hydrograph observation and literature reviews that the majority of glacier runoff occurs from July to September, so that the subsequent analysis in this thesis of glacier contribution modelled by WATFLOOD concentrates on these months. A summary of the initial calibration, parameter estimation and sensitivity analysis based on Pietroniro et al. (internal report) for the August to October months is included in this chapter as follows.

Initial model runs of select basins, both glacierised and non-glacierised, in the North and South Saskatchewan River basin headwaters displayed differences in the observed and simulated hydrographs plotted from August to October of 1991-1995. WATFLOOD did, however, simulate the recession curve from peak (August) to base flows (October) reasonably well. Differences were observed in the magnitude and timing of the peak flow. This could have been due to the poor glacier cover resolution in the NTS maps and unreliable initial conditions. The model runs 
began in August, and it is not ideal to begin a WATFLOOD simulation near the peak of the annual hydrograph since it is difficult to establish reasonable initial conditions. Following these initial observations, further tests were required and a model calibration using a sensitivity analysis was carried out to establish the robustness of the WATFLOOD modelling system for the purpose of simulating glacier runoff.

Hydrological model calibration has traditionally been conducted manually by running a number of model simulations, and manually adjusting parameters in a trial-and-error approach to reduce the difference between the observed and simulated hydrographs. This process is, however, labour intensive and difficult to conduct when a large number of parameters are calibrated to a long time series of data at numerous locations (Tolson and Shoemaker 2007). A number of optimisation algorithms have therefore been developed for automatic calibration. These algorithms search for a set of parameters that minimise (or maximise, as appropriate) objective functions, which are numerical measures of the difference between simulated and observed hydrograph data (Sorooshian and Gupta 1995). In the initial calibration and sensitivity analysis of WATFLOOD, Pietroniro et al. (internal report) use the Generalised Likelihood Uncertainty Estimation (GLUE) approach (Beven and Binley 1992) for parameter sensitivity analysis and model uncertainty evaluation, in parallel with Morris's method (Morris 1991) for sensitivity analysis. Sensitivity analysis evaluates the effect of individual parameters on the model output, and identifies the parameters that have the greatest impact so that they can be focused on in calibration. Analysis focused on the snowmelt and routing parameters that are normally determined through optimisation (Kouwen 2006), as opposed to assigning values from previous modelling experience. The parameters ranges were selected from previous experiences and they were set wide enough in order to find their optimum value. The snowmelt parameters 
for all the land use covers have the same range. The results from the sensitivity analysis of both methods showed comparable parameter sensitivity for the August to October simulation period. The routing parameters (lower zone drainage function (lzf), lower zone drainage function exponent (pwr) and river channel roughness- Manning's n- (R2)) are among the most sensitive parameters. The melting factor (MF), base temperature $\left(\mathrm{T}_{\text {base }}\right)$ and negative melt factor $(\mathrm{NMF})$ in the snowmelt regimes do not show a special sensitivity. The $\mathrm{R} 2$ routing parameter appears to have the most influence on the model outputs. Pietroniro et al. (internal report) conclude that the results highlight the need for intensive field investigations, ideally to evaluate the WATFLOOD simulations with true field estimates of glacier runoff. This is, however, beyond the scope of this project. This thesis therefore uses the parameter set resulting from this previous analysis by Pietroniro et al. (internal report) in WATFLOOD, with further analysis completed of the ability of WATFLOOD to model streamflow in the individual basins simulated and used to estimate glacial impact on streamflow.

In addition, it is worth mentioning a recent study by Bingeman et al. (2006) on the calibration, validation and sensitivity analysis of WATFLOOD for the Columbia River basin in British Columbia. They found that WATFLOOD could track each of the internal state variables (soil moisture, evaporation, snow accumulation, snowmelt and groundwater flow) and the statistical characteristics of streamflow with sufficient accuracy for operational use of the model. Sensitivity analysis showed that the model behaves in a realistic manner, and Bingeman et al. (2006) also suggested that the parameter set could be applied to many different watersheds. 


\subsection{Modelling Glacier Wastage and Melt with WATFLOOD}

The previous section on WATFLOOD operationalisaton and initial calibration and sensitivity analysis were completed prior to this thesis (Demuth and Pietroniro 2003, Pietroniro et al. internal report). The following sections describe how WATFLOOD was used to estimate glacier wastage contribution and Melt impact on streamflow as part of this thesis research. The basins modelled by WATFLOOD are listed with their attributes in Table 4.2 and shown in Figure 4.7.

Table 4.2 Basins modelled in the N and SSRB headwaters, including cumulative drainage area and percentage basin glacier cover

\begin{tabular}{lllll}
\hline Station Gauge Name & $\begin{array}{l}\text { Gauge } \\
\text { ID No. }\end{array}$ & $\begin{array}{l}\text { Drainage } \\
\text { area } \\
\left.\mathbf{k m}^{2}\right)\end{array}$ & $\begin{array}{l}\text { Glacier } \\
\text { cover } \\
\mathbf{1 9 7}\end{array}$ & $\mathbf{1 9 9 8}$ \\
\hline $\begin{array}{l}\text { North Saskatchewan River Basin } \\
\text { Mistaya River near Sask Crossing }\end{array}$ & & & & \\
Silverhorn Creek near the mouth & DA007 & 248 & 13.5 & 10.8 \\
North Sask River at Whirlpool Point & DA010 & 21 & 4.1 & 2.4 \\
Siffleur River near the mouth & DA009 & 1923 & 16.2 & 13.7 \\
North Ram River at Forestry Road & DA002 & 515 & 5.3 & 2.9 \\
Ram River near the mouth & DC011 & 347 & 0.0 & 0.0 \\
North Sask River at Sask Crossing & DC006 & 1854 & 0.3 & 0.1 \\
South Saskatchewan River Basin & DA006 & 1287 & 20.2 & 17.6 \\
Bow River at Lake Louise & & & & \\
Pipestone River near Lake Louise & BA001 & 422 & 9.4 & 7.3 \\
Johnston Creek near the mouth & BA002 & 306 & 4.3 & 2.2 \\
Bow River at Banff & BA006 & 123 & 0.6 & 0.2 \\
Brewster River near Banff & BB001 & 2205 & 3.4 & 2.2 \\
Redearth Creek near the mouth & BB004 & 110 & 1.2 & 0.3 \\
Spray River at Banff & BB005 & 151 & 2.9 & 1.6 \\
Goat Creek at Banff park boundary & BC001 & 750 & 1.3 & 0.7 \\
Cascade River above Lake Minnewanka & BC008 & 40 & 0.0 & 0.0 \\
Bow River near Seebe & BD005 & 452 & 0.6 & 0.1 \\
\hline
\end{tabular}




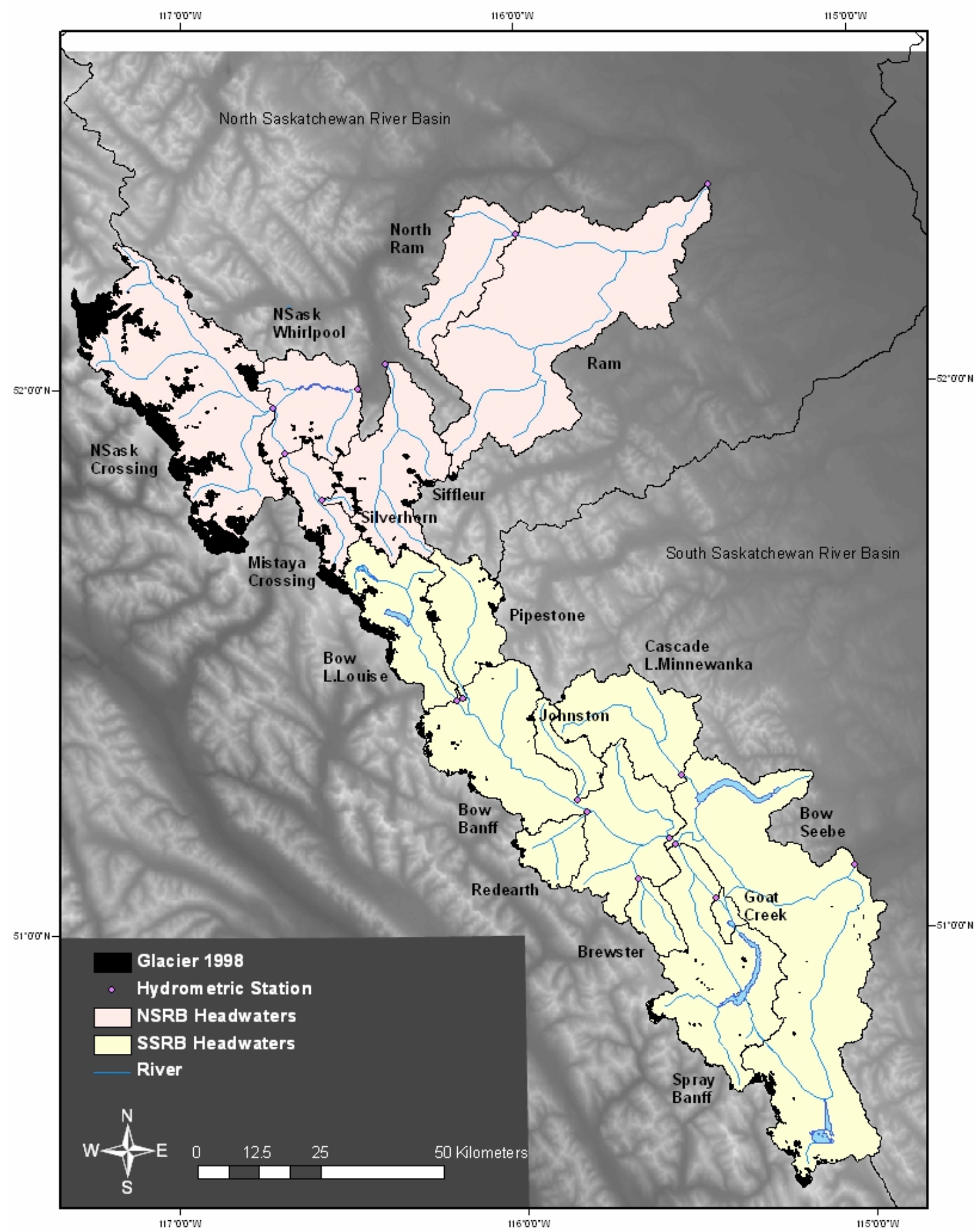

Figure 4.7 Basins modelled in the N and SSRB headwaters, underlain with $50 \mathrm{~m}$ DEM. Source: Data files from National Hydrology Research Centre, Environment Canada. 


\subsubsection{Model evaluation}

The ability of WATFLOOD to simulate streamflow in each of the simulated basins

(Table 4.2) was evaluated using the model efficiency $\left(\mathrm{R}^{2}\right)$ of Nash-Sutcliffe (1970):

$$
R^{2}=1-\frac{\sum_{i=1}^{n}\left(q_{o b s, i}-q_{i}\right)^{2}}{\sum_{i=1}^{n}\left(q_{o b s, i}-\bar{q}_{o b s, i}\right)^{2}}
$$

Where:

$$
\begin{array}{ll}
q_{o b s, i} & =\text { observed runoff }\left[\mathrm{L}^{3} \mathrm{~T}^{-1}\right] \text { at the catchment outlet } \\
q_{i} & =\text { simulated runoff }\left[\mathrm{L}^{3} \mathrm{~T}^{-1}\right] \text { at the catchment outlet } \\
\bar{q}_{\text {obs }} & =\text { average observed runoff }
\end{array}
$$

The Nash-Sutcliffe test is a measure of the ability of a model to predict about the 1:1 line between observed and simulated data. $\mathrm{R}^{2}$ values equal to 1 indicate a perfect fit between the observed and simulated data.

In addition the Mean Bias Difference (MBD) was calculated as defined below:

$$
\operatorname{MBD}=\frac{1}{n} \sum_{i=1}^{n}\left(q_{o b s i}-q_{i}\right)
$$

The Mean Bias Difference provides information on the long term performance of a model. A positive value gives the average amount of underestimation in the simulated value and a negative value gives the average amount of overestimation. The smaller the absolute value, the 
better the performance of the model. A disadvantage of this test is that overestimation of an individual observation will cancel underestimation in a separate observation (Skeiker 2006).

The 1975 Landsat glacier cover data were used within WATFLOOD for this analysis and a ten year time period with 1975 as the mid-point (1970-1980) chosen, with a continuous run for this time period starting November 1969. Analysis for the entire time period, however, was not always possible due to the lack of observed streamflow data, so that the closest time period with ten years available data was selected, varying between basins and ranging from 1970-1986. Occasionally gaps were found in the winter period of observed streamflow data. These were omitted from the analysis and considered less important since the simulated summer streamflow is the focus of the glacier impact and contribution estimation. The analysis was not completed for the North Saskatchewan River at Saskatchewan Crossing basin since observed streamflow data were only available from 1951-1969. In addition to the statistical tests, the observed and simulated hydrographs from each basin were plotted and observations were made primarily concerning the magnitude and timing of the peak flows.

\subsubsection{Estimating glacier wastage and Melt contribution}

The model was run with a continuous time series of data beginning in the month of November to avoid establishing initial conditions at peak streamflow or in the late summer months used to estimate glacier contribution. The model was initially set up for the SSRB from 1961-1990, the time period chosen to correspond with the standard IPCC dates for current climate scenarios. For the NSRB, however, the model files were originally set up from 19721990 due to insufficient observed streamflow gauge data in the early years required to initialise and calibrate the model. These time series for the S and NSRB were then extended to 2005 to 
simulate more recent years. Two continuous simulation runs were made using firstly the updated glacier cover derived from Landsat imagery from 1975, and then the glacier cover from 1998. Ten year sub-sets of the continuous simulation runs were extracted to coincide with the glacier cover for 1975 (1970-1980) and 1998 (1993-2003). For the North Saskatchewan River basin, however, the time period relating to the 1975 glacier cover was from 1972-1982 due to the lack of WATFLOOD files for 1970 and 1971. Estimation of glacier runoff was achieved by setting the calibrated glacier melt enhancement factor (gladjust) (section 4.2.1.3) to zero in the WATFLOOD model. This allowed snow to accumulate and melt in the glacierised portions of the basins, but did not allow the melting of ice once the annual snow pack was depleted. The same results are achieved if the glacier land cover is replaced with bare rock (at the same elevation as the glacier surface). The model was run first allowing the glacier ice to melt, and then with the glacier melt enhancement factor set to zero, and the difference in streamflow output was calculated as the glacier runoff. With reference to the terms in section 1.3, setting the glacier melt enhancement factor to zero changes neither the volume nor rate of snowfall onto the glacier $\left(P_{s}\right)$ and snow that melts from the glacier surface $\left(M_{s}\right)$. Therefore in the simplified annual glacier mass balance $d m / d t$, equation 1.3:

$$
d m / d t=P_{s}-M_{s}-M_{i}
$$

it is only $M_{i}$ that is altered by setting the glacier melt enhancement factor to zero, so that the difference in streamflow output can be attributed solely to $M_{i}$, since all other streamflow input and output variables remain constant. In positive and zero mass balance years $M_{i}$ is less than, or equal to, $P_{s}-M_{s}$ respectively, thus the difference in simulated streamflow with and without glaciers will equal Melt. In negative mass balance years $M_{i}=$ wastage $+P_{s}-M_{s}$ (equation 1.4), with wastage being the volume of ice melt that exceeds $P_{s}-M_{s}$, and the difference in simulated 
streamflow will therefore equal the combined wastage and Melt. It is assumed that wastage occurs in the majority of years simulated, indeed Peyto Glacier has a positive mass balance for only three years $(1973,1974$ and 1976) in the time period $1970-2003$, therefore the average WATFLOOD simulated glacier runoff for a ten year time period is assumed to be combined glacier wastage and Melt. There is no difference in streamflow output when a non-glacierised basin is simulated with and without glacier melt activation.

The modelled combined glacier wastage and Melt volume for July to September was found as a percentage of the modelled streamflow with glaciers. The lack of continuous measured streamflow data prevented observed data being used to calculate the percentage glacier contribution to flow. The simulated combined wastage and Melt was not calculated as a percentage of the annual flow because the results would be misleading, since glacier contribution to streamflow in terms of Melt is only significant on a seasonal time scale. There are, however, limitations to using WATFLOOD to model glacier runoff since it is neither a physically based nor detailed glacier model.

\subsubsection{Limitations of estimating glacial impact on streamflow with WATFLOOD}

WATFLOOD simulates glaciers in a conceptual manner previously described in section 4.2.1.3. The lack of physical data for the vast majority of the large number of glaciers in this region, however, would prevent the application of a detailed, physically based glacier model within WATFLOOD if one was developed. Complex physical processes within the model are simplified, such as glacier runoff routing, which assumes that all the ice melt from the glacier reaches the basin streamflow. In reality a glacier has a complex en-glacial drainage system (section 2.3.4), which delays runoff and may trap some of the ice melt, which also may enter a 
groundwater system and not reach the glacier basin outflow. In addition, the land cover was generalised into nine categories, which were not updated throughout the model simulations. Glacier cover within the model, therefore, did not reflect wastage runoff in years of negative mass balance as a loss of total glacier ice due to the lack of a glacier cover decline algorithm within WATFLOOD. Every year, therefore, the glacier cover remained the same at either the 1975 or 1998 extent. Another limitation is that the degree-day melt factor and glacier melt enhancement factor were determined from calibration, and remained constant throughout model simulations when in reality they vary (section 4.2.1.3). In addition, the model does not accumulate snow into the glacial system by progressive compression and metamorphism to ice, then transferral down the glacier. A major limitation is that WATFLOOD does not account for the differences in snowmelt on a glacier surface relative to surrounding bare rock, such as lower surface temperatures, which in reality results in less snow melting from the glacier surface than surrounding land covers. Glaciers in the model are therefore not treated as dynamic systems which accumulate snow into the glacier and replace the equivalent snowmelt volume with ice melt runoff in the late summer. This increased rate of snowmelt on the glacier surface than would occur in reality causes a larger area of ice surface to be exposed to solar radiation and thus melt, therefore it is possible that WATFLOOD simulates an overestimation of glacier runoff.

Another simplification is that within each GRU element, each land cover was subject to the same meteorological conditions and the elevation was constant, despite the large size of each GRU ( 9 by $9 \mathrm{~km}$ for the NSRB and 5 by $5 \mathrm{~km}$ for the SSRB) meaning that in reality the topography and local climate would vary throughout the GRU. This is problematic when modelling a glacier system since there is no distinction between an accumulation and ablation zone, with the accumulation zone receiving relatively more snowfall in reality. There are also 
data missing from the meteorological and streamflow data records, requiring interpolation. In addition, the meteorological stations are generally located at similar, low, altitudes, with the glaciers located at a higher elevation requiring lapse rate adjustments. Error could have also been introduced into the meteorological and streamflow records in the field data collection, especially with the use of less accurate equipment in the earlier years. Also, whilst WATFLOOD simulates glacier runoff, preventing glacier ice from melting is not an accurate simulation of streamflow from a basin from which a glacier has disappeared. To do this the basin topography would have to be altered to match the bedrock as opposed to the glacier ice surface, and processes such as bedrock scouring by the glacier could result in lake formation and delays in basin runoff. Altering the DEM to the surface elevation of the bedrock below the glacier was not possible, however, due to the lack of ice depth data for glaciers in the region. The conceptual modelling of glaciers as simple percentages of ice land cover within WATFLOOD, and the inaccuracies involved in precipitation inputs and lack of elevation change over the glacier, in addition to the simplified modelling of snowmelt from the glacier, means that it is unlikely that if there were years of observed zero mass balance the modelled glacier runoff would equal the annual snow that accumulates into the glacier system as measured from field data. Discrepancies should be expected when attempting to relate individual years of simulated glacier runoff to observed data such as mass balance measurements, and an evaluation of the ability of the model to simulate glacier runoff from a small, highly glacierised basin is conducted as described in section 4.8. 


\subsection{Glacier Wastage and Melt from a Hydrological-hypsometric Comparison}

\subsubsection{Method}

To estimate combined glacier wastage and Melt contribution, glacierised and nonglacierised basins with similar area, hypsometric data, closely located to each other and with a common time period of streamflow data were selected from Tables 3.1 and 3.2, and their discharges compared. These comparison basins in the headwaters of the N and SSRB are shown in Figure 4.8, with the comparison pairs and their attributes given in Table 4.3. The hypsometric curve attributes given in Table 4.3 refer to the maximum, minimum and mean basin elevations, the standard deviation of elevations within the basin and the hypsometric integral as defined below. Hypsometry describes the frequency distribution of elevations. The hypsometric curve (elevation plotted against cumulative area) represents the relative proportion of a basin area that lies below a given height (Strahler 1952). The hypsometric curve of each basin was extracted from the digital elevation model (DEM) using EnSim Hydrologic (EnSim, CHC/NRC). When expressed in non-dimensional terms by normalising the elevations relative to the total elevation range, and cumulative area relative to the total cumulative area range, the hypsometric curves of basins can be compared as a measure of basin similarity. The hypsometric integral is a dimensionless parameter calculated as the area under the hypsometric curve with a value ranging from 0 to 1, relating the percentage of total elevation to the percentage of cumulative area. If $X(y)$ is the relative proportion of the basin area that lies at or above a given elevation $y$, then the relative frequency of area change with elevation can be described by:

$$
X(y)=\int_{0}^{y} x(y) \mathrm{d} y
$$

Where $0 \leq X \geq 1$ and $0 \leq y \geq 1$ (as stated in Luo 1998). 
The hypsometric integral (HI) can be estimated using the following elevation-relief ratio equation (Pike and Wilson 1971):

$$
\mathrm{HI}=\left(H_{\text {mean }}-H_{\min }\right) /\left(H_{\max }-H_{\min }\right)
$$

Where $H$ mean and ( $H$ max- $H$ min) are the mean elevation and the elevation drop of the basin, respectively. Hypsometry is generally used to infer the stage of geomorphic development (Strahler 1952) with a higher hypsometric integral and convex, as opposed to concave, upper curve indicating a youthful, less fluvially dissected basin. In terms of glacierised basins, hypsometry can be used to determine the degree of basin glacial modification since the transition from non-glacierised to glacierised conditions following the development of cirque glaciers tends to skew the elevation frequency distribution to higher elevations. With the development of longlived valley glaciers, and thus a lowering of the equilibrium line altitude (ELA), glacial modification then shifts the frequency distribution peak back to lower elevations (Brocklehurst and Whipple 2004). Many studies have, however, found variations to this generalisation, in glacierised basins local circumstances such as the presence of ice caps, major hanging valleys and isolated geologic structure can have a major impact on the hypsometry (Brocklehurst and Whipple 2004). Due to the impact of hypsometry on local climate since elevation affects temperature, precipitation and basin runoff regimes, basins with similar hypsometric integrals and hypsometric curves were deemed suitable for comparison (Figure 4.9). 


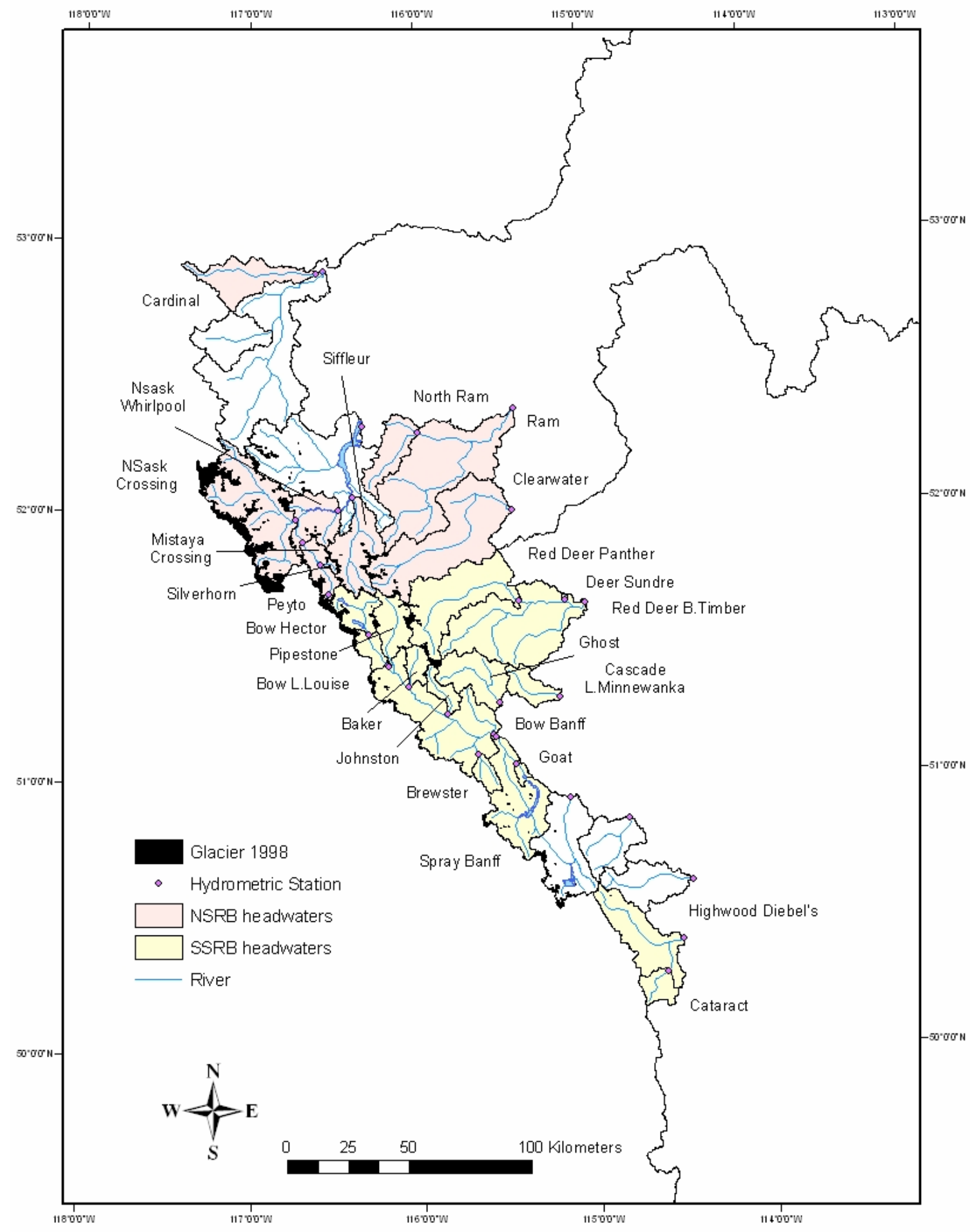

Figure 4.8 N and SSR headwater basins compared to estimate combined glacier wastage and Melt contribution to flow.

Source: Data files from National Hydrology Research Centre, Environment Canada. 
Table 4.3 N and SSR headwater basins compared, with their area, common period of flow record, and hypsometric attributes.

(See text for explanation of hypsometric data)

\begin{tabular}{|c|c|c|c|c|c|c|c|c|}
\hline \multirow{3}{*}{ Size } & \multirow{3}{*}{ Basin } & \multirow{3}{*}{$\begin{array}{l}\text { Area } \\
\left(\mathrm{km}^{2}\right)\end{array}$} & \multirow{3}{*}{$\begin{array}{l}\text { Comparison } \\
\text { period }\end{array}$} & \multicolumn{5}{|c|}{ Hypsometric curve } \\
\hline & & & & \multicolumn{4}{|c|}{ Elevation m.a.s.l. } & \multirow[b]{2}{*}{ Integral } \\
\hline & & & & Max & Min & Mean & $\begin{array}{l}\text { Standard } \\
\text { Deviation } \\
\end{array}$ & \\
\hline \multirow{2}{*}{$\stackrel{\bar{\Xi}}{\underset{\Xi}{\Xi}}$} & Peyto Glacier & 22.7 & \multirow{2}{*}{$1971-77$} & 3056 & 1985 & 2590.0 & 185.5 & 0.565 \\
\hline & Silverhorn Creek & 21.0 & & 2935 & 1780 & 2453.8 & 273.4 & 0.584 \\
\hline \multirow{4}{*}{ 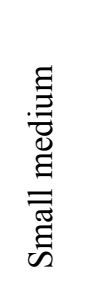 } & Baker Creek & 125.8 & \multirow{2}{*}{$1973-76$} & 3215 & 1461 & 2219.2 & 293.2 & 0.406 \\
\hline & Johnson Creek & 122.9 & & 3074 & 1516 & 2257.0 & 309.5 & 0.476 \\
\hline & $\begin{array}{l}\text { Mistaya nr Sask } \\
\text { Crossing }\end{array}$ & 248.0 & \multirow{2}{*}{$\begin{array}{l}1970-80 \\
1990-93\end{array}$} & 3213 & 1574 & 2267.0 & 377.6 & 0.422 \\
\hline & Ghost River & 209.8 & & 3058 & 1549 & 2213.8 & 300.5 & 0.44 \\
\hline \multirow{8}{*}{$\underset{\Xi}{\stackrel{\Xi}{\Xi}} \stackrel{\Xi}{\Xi}$} & $\begin{array}{l}\text { Bow R. below } \\
\text { Hector Lake }\end{array}$ & 279.4 & \multirow{2}{*}{$1975-76$} & 3196 & 1684 & 2297.3 & 332.3 & 0.396 \\
\hline & North Ram River & 347.3 & & 3247 & 1557 & 2291.6 & 326.2 & 0.425 \\
\hline & Pipestone & 306.7 & \multirow{2}{*}{$\begin{array}{l}1975-77 \\
1993-2003\end{array}$} & 3247 & 1557 & 2291.6 & 362.2 & 0.425 \\
\hline & North Ram River & 347.3 & & 2718 & 1467 & 1882.0 & 234.5 & 0.321 \\
\hline & $\begin{array}{l}\text { Bow River } \\
\text { at Lake Louise }\end{array}$ & 422.4 & \multirow[t]{2}{*}{$1973-80$} & 3196 & 1563 & 2196.2 & 367.4 & 0.387 \\
\hline & Cascade River & 452.1 & & 3203 & 1539 & 2238.0 & 314.7 & 0.419 \\
\hline & Siffleur River & 514.7 & \multirow{2}{*}{$1975-80$} & 3201 & 1397 & 2300.0 & 366.3 & 0.491 \\
\hline & Cardinal River & 493.4 & & 2875 & 1305 & 1847.7 & 299.9 & 0.335 \\
\hline \multirow{2}{*}{$\sum_{\Sigma}^{\frac{1}{0}} \underset{\Xi}{0}$} & $\begin{array}{l}\text { North Sask at } \\
\text { Crossing }\end{array}$ & 1287.1 & \multirow[t]{2}{*}{$1959-69$} & 3482 & 1395 & 2212.0 & 456.1 & 0.394 \\
\hline & Clearwater River & 1342.8 & & 3239 & 1402 & 2087.8 & 401.5 & 0.371 \\
\hline \multirow{2}{*}{ 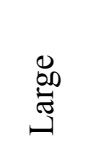 } & $\begin{array}{l}\text { North Sask. R } \\
\text { at Whirlpool P. }\end{array}$ & 1923.0 & \multirow{2}{*}{$\begin{array}{l}1970-80 \\
1993-2003\end{array}$} & 3482 & 1360 & 2190.0 & 456.7 & 0.345 \\
\hline & Ram River & 1853.5 & & 3080 & 1094 & 1810.2 & 360.0 & 0.350 \\
\hline
\end{tabular}



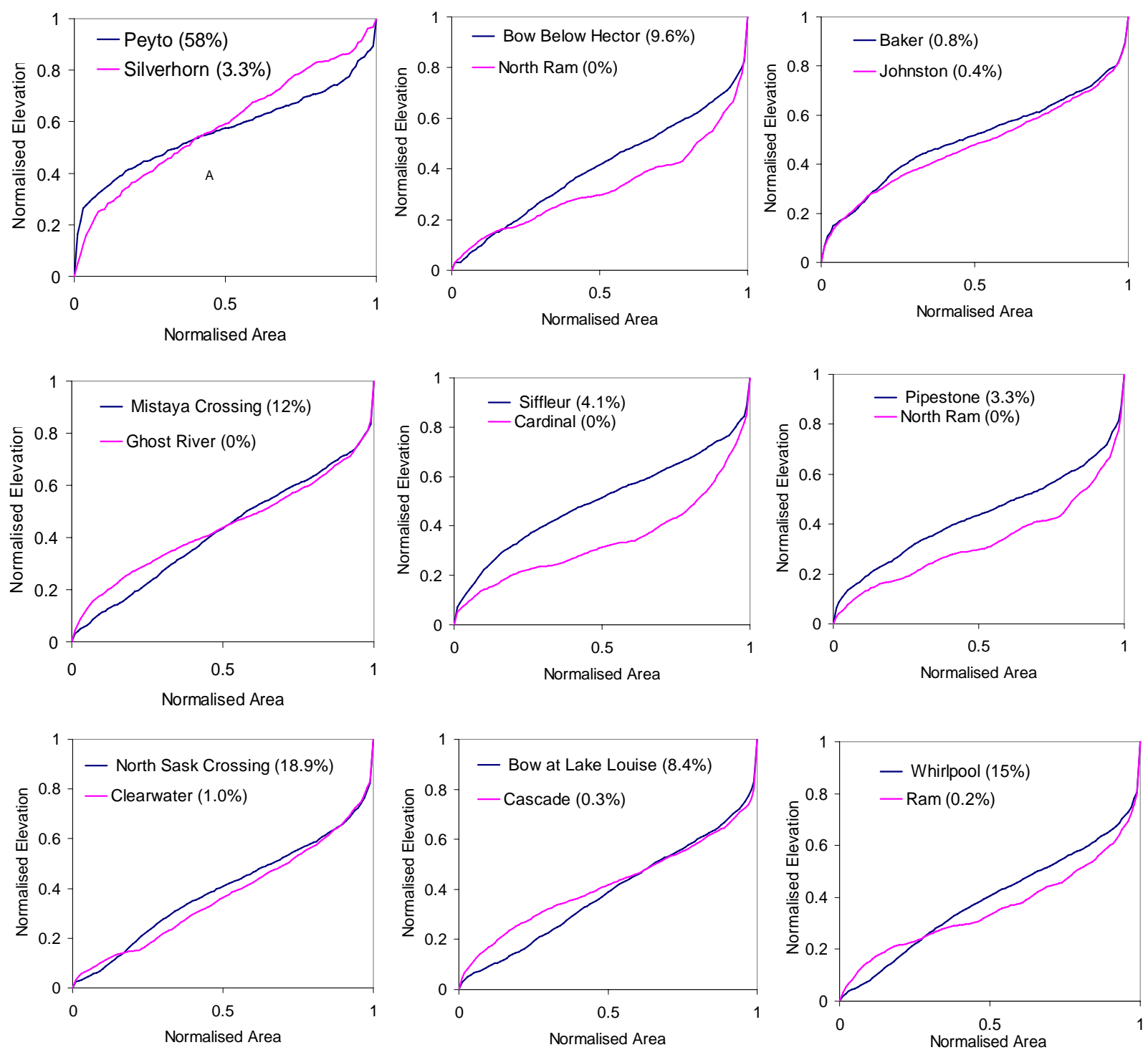

Figure 4.9 Hypsometric curves for the compared glacierised and non-glacierised basins. Percentage basin glacier cover is shown in parenthesis as an average of the 1975 and 1998 glacier cover.

Glacier runoff was calculated as the difference between the observed streamflow per unit area from the similar glacierised and non-glacierised basins from July to September, with the streamflow comparison made after converting discharge to $\mathrm{mm}$ to account for differing basin areas. The resulting glacier runoff could then be calculated as a percentage of the observed July to September streamflow of the glacierised basin. This evaluation was concentrated in the July to 
September period because this is when glacier wastage and Melt should produce the greatest and most consistent contrast between the basin flows. With reference to the terms in section 1.3, basin streamflow $(Q)$ in the July to September period can be expressed as:

$$
Q=P_{r}+P_{s}+M_{s}+M_{i}-E-G
$$

Where:

$P_{r}=$ Rain precipitation

$E=$ Evaporation

$G=$ Groundwater inputs to/losses from streamflow

Since the majority of snowfall and melt occurs in the winter and spring, respectively, $P_{s}$ and $M_{s}$ with respect to July to September streamflow inputs will consist of any summer snowfall and subsequent melt that occurs, and $M_{s}$ would also include any winter snowmelt that was delayed from reaching the basin streamflow until late summer. The hydrological-hypsometric comparison method assumes that the glacierised and non-glacierised comparison basins have the same summer rainfall $\left(P_{r}\right)$, snowfall $\left(P_{s}\right)$, snowmelt $\left(M_{s}\right)$, evaporation $(E)$ and groundwater $(G)$ inputs and losses from the basin streamflow. Therefore, the difference between compared basin streamflows $\left(Q_{\text {diff }}\right)$ is equal to ice melt only $\left(M_{i}\right)$, which in years of positive and zero mass balance should equal Melt, and in years of negative mass balance should equal combined Melt and wastage. These are unrealistic assumptions and major limitations to the method, as discussed in section 4.2.2 below. 
In accordance with the years of available glacier cover data (1975 and 1998), two time periods were selected for basin comparison, 1970-1980 and 1993-2003, within which time frames the average discharge comparisons were made (the number of years within the time frame depended on the available streamflow data). The streamflow coefficient of variation $(C V)$ both annually and in the July to September months was also calculated (equation 4.1). The streamflow hydrographs of the compared basins (Table 4.3) for the summer months are presented in Figure 4.10. 

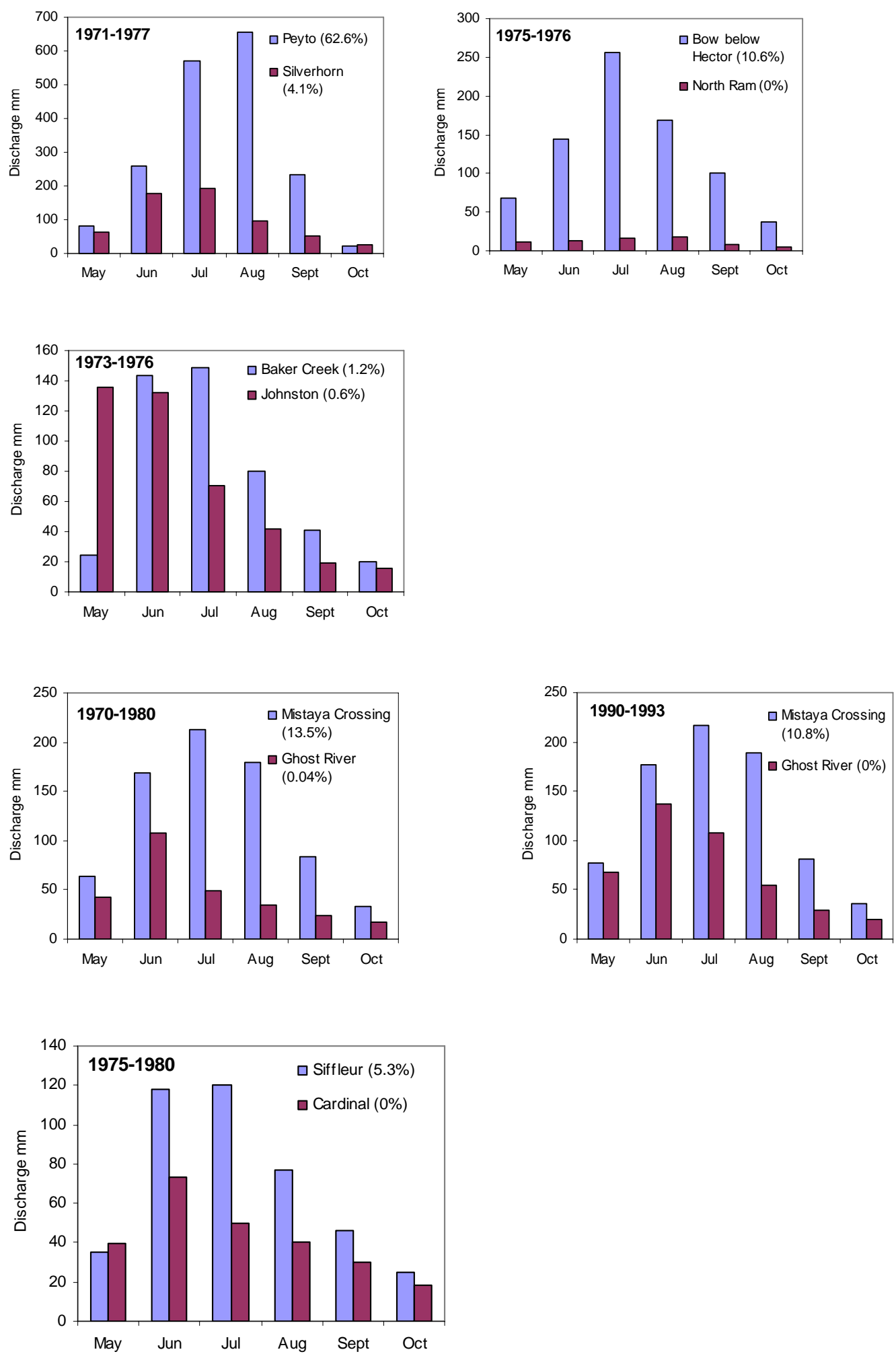

Figure 4.10 Observed streamflow hydrographs for the compared glacierised and non-glacierised basins for the 1975 and 1998 periods. Percentage basin glacier cover is shown in parenthesis for the appropriate time period. Source data: HYDAT (Environment Canada WSC: HYDAT) 
Figure 4.10 continued
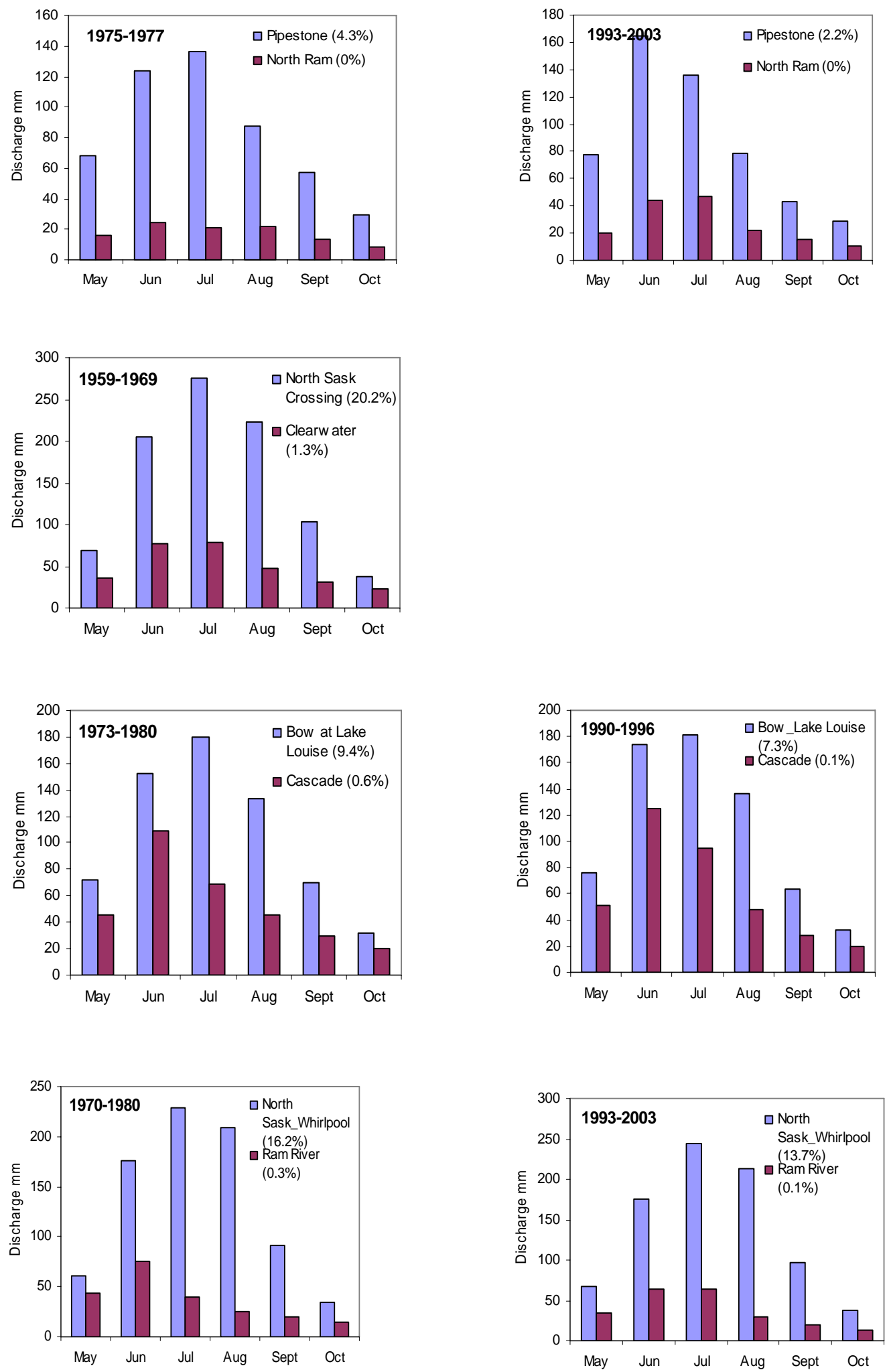


\subsubsection{Limitations}

There has been little direct, systematic comparison of glacierised and non-glacierised (nival) basins, despite the need to do so for a better understanding of their hydrographs prior to investigating how they vary differently in response to climate forcing over time, and in light of the increasing interest in their comparative ecology (Fleming 2005). Mass balance and modelling studies of glacier contribution have their limitations and the basin comparative method is instructive as an alternative approach (Fleming and Clarke 2003). The main limitation in collecting data for this basin comparison approach is the lack of matching hydrometric observed streamflow records amongst the sub-basins analysed. The different periods of flow data and the deficiencies (gaps) or insufficiencies (very short records) constrained the number of basins from which the most similar were chosen to compare. Similar problems have been encountered in previous studies (Moore 1992, Fleming and Clarke 2003) and thus the importance of continuous and regular flow data measurements and the need for an increase in the number of gauged basins in the field is emphasised. To date it appears that basin comparative studies (e.g. Young 1991) have yet to use flow differences to calculate the percentage glacier contribution. This may be due to the large number of limitations with this approach which are discussed as follows.

The assumption that in the July to September period $Q_{\text {diff }}=M_{i}$ is likely a flawed one since the compared observed streamflow hydrographs (Figure 4.10) show large differences in the months of May and June which suggest that there are factors other than basin glacier presence causing differences in streamflow. In these months, streamflow primarily consists of snowmelt runoff, with glaciers contributing to flow typically after the snowmelt in July to September, thus the differences in May and June suggest that the supposedly similar glacierised and nonglacierised basin pairs have different climate regimes and snow accumulation and melt. This 
could be because the glacierised sub-basin of each basin comparison pair is of higher elevation and often located further to the west than the non-glacierised sub-basin, resulting in different precipitation (rainfall and snowfall) regimes and temperatures, affecting evaporation rates and snowmelt. For example, Peyto Glacier basin is right on the continental divide, and very likely has a different precipitation regime from Silverhorn basin, to which it is compared, located further east. In addition, whilst basins with similar hypsometry were chosen to compare, topographic differences still exist between the basins, which would result in different snow accumulation patterns such as snow drifting. Also, it was not possible to consider aspect as a common factor requirement in selecting basins for comparison. This is due to the lack of streamflow data limiting the number of basins which could be compared, of which only four pairs have the same aspect. Therefore differences in streamflow arise from differences in upslope/downslope precipitation regimes and solar radiation, with slower snowmelt and less evaporation on north versus south facing slopes, as a result of comparing two basins with different aspects.

In addition, lack of data prevented groundwater systems being a common factor requirement between basins, thus contrasting groundwater systems could also cause differences in the observed streamflow. Similarly, differing land covers (excluding glacier presence) in the compared basins will result in differing delays in runoff and snow accumulation distributions and melt, especially for the larger basins which have a greater variety of land covers and thus are more likely to have differences in the streamflow as a result. It should also be considered that if the basins in each comparison had exactly the same hypsometry and climate regime, they would either both be glacierised or non-glacierised. Whilst many of these differences will affect the streamflow in terms of snowmelt runoff in May and June, the differences between the basins 
compared will also account for some of the differences in streamflow in the July to September period, when summer snowfall can occur, and thus the difference in the late summer observed streamflow from a glacierised and non-glacierised basin cannot be solely attributed to glacier wastage and Melt.

The compared basins likely have varying precipitation, both in terms of rainfall and summer snowfall, different temperatures affecting snowmelt and evaporation, and differing groundwater systems. Therefore, with reference to equation 4.8 , the difference in streamflow from a glacierised and non-glacierised basin is the result of differences in each of the terms, not just ice melt, and will also include differences in flow as a result of delayed basin runoff from factors other than glacier presence, such as differing land covers. The purpose of this approach, which is used to estimate combined glacier wastage and Melt in the July to September period, is therefore to compare the results with those of WATFLOOD. This basin comparison method is used due to the lack of streamflow and glacier data, which prevents the use of other methods, such as mass balance modelling, to estimate combined glacier wastage and Melt for the $\mathrm{N}$ and SSRB region with which to compare the WATFLOOD results. The method limitations of this basin comparison approach must be taken into consideration when analysing the results of glacier contribution and impact on streamflow.

\subsection{Glacier Wastage from Ice Volume Estimation and Change}

Glacier wastage was calculated as the difference in volume of the glaciers in the $\mathrm{N}$ and SSRB headwaters between 1975 and 1998. With reference to the terms in section 1.3, net loss of glacier ice volume per year resulting in a negative net mass balance occurs when: 


$$
M_{i}>P_{s}-M_{s} \quad \text { when } d m / d t<0
$$

Where, according to equations 1.4 and 1.5, $M_{i}=$ Wastage $+P_{s}-M_{s}$ and Melt $=P_{s}-M_{s}$.

Therefore from 1975-1998, the glacier net volume change is the sum of the net volume losses (wastage) for each negative mass balance year minus the sum of the net volume gains for each positive mass balance year, or:

$$
\text { Net wastage } 1975-1998=\sum_{i=1}^{n} M_{i}-\left(P_{S}-M_{S}\right)
$$

Since for years of positive mass balance $M_{i}-\left(P_{s}-M_{s}\right)$ will be negative since snow accumulation into the glacier system is greater than ice melt, and for years of negative mass balance $M_{i}-\left(P_{s}-M_{s}\right)$ will be positive since snow accumulation into the glacier system is less than ice melt.

Glacier volumes are difficult to measure, usually involving ground-based radar thickness sounding techniques (e.g. Holdsworth et al. 2006) that can be cumbersome and time consuming. Airborne sounding is also possible, particularly for non-temperate ice masses where radar energy is transmitted easily through ice that is below its melting temperature. From general glacierclimate considerations, however, glaciers in the Nelson Drainage basin are temperate (Pietroniro et al. internal report). Also, with the exception of Peyto, there is a significant lack of data on the thickness and mass balance of glaciers in the N and SSRB headwaters, and previous studies were forced to extrapolate volume loss results from Peyto Glacier over a region. To avoid this approach, since the results could be misleading due to Peyto having a greater area than the population median (Demuth et al. 2008), a regionalisation technique based on empirical volumearea scaling was used. The volume of a glacier $(V)$ is related with its surface area $(A)$ and a power relationship is commonly applied: 


$$
V=\mathrm{c}_{0} A^{\mathrm{c} 1}
$$

Where $\mathrm{c}_{0}$ and $\mathrm{c}_{1}$ are empirical constants, which are often determined from measured $V$ and $A$. With the increasing availability of glacier volume measurements from methods such as radioecho sounding, Chen and Ohmura (1990a) determined values for the constants in equation 4.10 from the data of 63 mountain glaciers from different regions in Europe and North America:

$$
V=28.5 A^{1.357}
$$

With the coefficient of determination $r^{2}=0.98$. The volume units are $10^{6} \mathrm{~m}^{3}$ while the surface area units are $10^{6} \mathrm{~m}^{2}$. With the exception of 17 glaciers in Svalbard, it was found that the values for $\mathrm{c}_{0}$ and $\mathrm{c}_{1}$ (equation 4.10 ) ranged from 17 to 30 and 1.15 to 1.52 respectively, due to the fact that different types of glaciers were involved and volume measurements of different accuracies were used. Following this and recognising a limitation in the globally available data on glacier volumes, Bahr et al. (1997) studied the theoretical scaling behaviour of glacier geometry, slope, force balance and mass balance, and also determined constants for the volumearea power law relationship consistent with the existing body of $V$ - $A$ observations for broad categories of glacier types. In doing so they separated observed volumes from those that were estimated (using theoretical ice thicknesses based on surface slope and a limiting basal shear stress condition). Glacier volume depends on the product of the ice length, width and thickness, and these dimensions can be re-written to express the volume as a function of the surface area and four closure choices for width, slope, side drag and mass balance (Bahr et al. 1997). Bahr et al. (1997) note that many closures are possible, but found that reasonable choices supported by data from 144 glaciers (other than ice caps and ice sheets) located in Europe, North America, 
central Asia and the Arctic, were those consistent with earlier empherical work by Chen and Ohmura (1990a) (equation 4.11), where $\mathrm{c}_{0}=28.5$ and $\mathrm{c}_{1}=1.357$ for valley glaciers and 1.25 for ice caps and ice sheets, $\mathrm{c}_{1}$ being a scaling component, with a regression coefficient $r^{2}=0.99$. Bahr et al. (1997) demonstrated that there is a physical basis to the volume-area power law relationship.

The size distribution (for the most part $A<20 \mathrm{~km}^{2}$ ) and glacier setting/configurations for the Nelson Drainage basin are similar to those of the regions considered by Bahr et al. (1997) and Chen and Ohmura (1990a), and Hopkinson and Young (1998) and Debeer and Sharp (2007) deem this $V$-A power law relationship (equation 4.11) suitable for use on their study areas, which include a selection of glaciers in the SSRB headwaters. Equation 4.11 was therefore applied to determine individual glacier volumes and sum them for regions of the N and SSRB headwaters (regions are shown in Figures 3.2 and 3.3) for both the 1975 and 1998 glacier areas. Demuth et al. (2008) applied this $V$-A relationship to glaciers in the $\mathrm{N}$ and SSRB, and the work of this thesis re-calculates the glacier volumes and basin total glacier volume loss after correcting the division of glacier cover amongst basins and re-determining the cumulative glacier cover for each basin. It has been noted in comparative studies using direct volume and area change data that the error in the predicted volume changes for individual glaciers can be large (e.g., Granshaw and Fountain 2006). When the $V$ - A scaling law is applied to large numbers of glaciers, however, it should result in an appreciably smaller error since the error associated with the regression equation for Bahr et al.'s (1997) power law is randomly distributed (Demuth et al. 2008). Where observed streamflow records were available, glacier wastage (expressed as water equivalent (w.e.) by assuming a specific gravity of 0.9167 ) was then found as a percentage of streamflow, both for the July to September period and annually (for the glacier year), as in Demuth et al. 
(2008) for a smaller number of basins (seven) in the N and SSRB. For the Spray River at Banff (gauge $05 \mathrm{BC} 001$ ) the flow is regulated thus wastage was not calculated as a percentage of July to September streamflow since the results would be misleading.

A limitation with this approach is that calculating wastage as the glacier volume change from 1975-1998 (the equivalent of equation 4.9) gives the net glacier wastage, which may not be equal to the total glacier wastage over the time period, which is the sum of the net volume losses for only the negative balance years. Therefore, if there are any years of positive mass balance within the 1975-1998 time period, the total glacier wastage which enters the streamflow will not be equal to the net glacier wastage as defined in equation 4.9. It was not possible to determine whether there were years of positive mass balance for individual glaciers in the time period, and thus calculate total glacier wastage, due to the lack of mass balance data for the vast majority of glaciers in the region. It should therefore be considered that total wastage contribution to streamflow from 1975-1998 may be an underestimation if there are years of positive mass balance in the glacier record, though it is likely that the majority of mass balance years are negative since Peyto Glacier has only one positive mass balance year in the 1975-1998 time period in 1976 (Young 1981, Demuth and Keller 2006). In addition, some of the basins did not have a streamflow record spanning the 1975-1998 time period, thus the net glacier wastage was divided by the total number of years to give the annual average wastage, and this was found as a percentage of the average streamflow for the time period available. This assumes that there was an equal amount of wastage contribution to streamflow each year, which is highly unlikely due to climate variations resulting in different volumes of wastage each year. Indeed, Peyto Glacier net mass balance varies widely on an annual basis between approximately negative 200-1300 mm (w.e.) between 1975 and 1998, excluding the positive mass balance year 1976 (Young 1981, 
Demuth and Keller 2006). The wastage percentage contribution to streamflow results must therefore be considered as an average for the 1975-1998 time period, with annual wastage contributions varying around this average depending on climate variations and zero wastage contributions in positive mass balance years. The main limitation to this approach was the lack of observed streamflow data with which the percentage glacier contribution could be calculated, and also lack of yearly mass balance data for the vast majority of glaciers in the region.

\subsection{Comparison of Glacier Wastage and Melt Results}

Three different methods (hydrological modelling, hydrological-hypsometric basin comparison and volume-area relationship application) for estimating glacier contribution to streamflow have been described and since they were applied to some of the same headwater basins, the results could be compared. The main limiting factor was finding a common time period for which to compare the glacier contribution results. Firstly, the WATFLOOD and hydrological-hypsometric results of combined glacier wastage and Melt were compared and the results analysed as an indication of whether the WATFLOOD model is a good simulator of glacier contribution on a regional scale.

\subsection{Calculating Melt}

The volume-area scaling approach (section 4.5) could only produce net glacier wastage for 1975-1998, from which a yearly average could be calculated. Therefore, in order to compare the WATFLOOD and hydrological-hypsometric results, combined glacier wastage and Melt from these methods was required for this same time period. This was difficult, if not impossible, for the hydrological-hypsometric comparison due to the lack of continuous streamflow records 
for the comparison basins for the 1975-1998 time period. Thus, the WATFLOOD model was run from 1975-1998 with the 1975 glacier cover for the former half of the time period and the 1998 glacier cover for the latter half. The total combined glacier wastage and Melt contribution in the July to September period estimated by WATFLOOD (as the difference between simulated streamflow with and without glaciers, see section 4.3.2) from 1975-1998 was then divided by the number of years to give the average seasonal glacier wastage and Melt contribution for the time period. This was then compared to the average glacier wastage contribution from the volumearea relationship method for 1975-1998, with wastage runoff assumed to occur in the July to September months. Glacier contribution to streamflow in terms of Melt is only significant on a seasonal, not annual, time scale, with Melt contributing to the streamflow volume in the July to September period. The difference between glacier wastage (volume-area relationship) and combined glacier wastage and Melt (WATFLOOD) in the July to September period could therefore be calculated as an estimation of the volume of Melt as an average of the 1975-1998 time period. This was found as a percentage of the July to September streamflow as simulated by WATFLOOD (with glaciers), the lack of continuous hydrometric observed streamflow data from 1975-1998 for every basin for which Melt was calculated prevented using the observed streamflow data to find the percentage contribution.

\subsection{Glacier Wastage and Melt Contribution to Peyto Glacier Basin}

Whilst there is a severe lack of data for the vast majority of glaciers in this region, mass balance data are available for Peyto Glacier in the Mistaya River basin (labelled in Figure 3.2). A detailed analysis of the correspondence of this mass balance data to climate changes can be found in Demuth and Pietroniro (2003) and Demuth and Keller (2006). A focus study was 
therefore conducted on Peyto Glacier basin so that the results from the three methods used on a regional scale when applied to Peyto Glacier basin could be compared to those from alternative methods and previous research on Peyto Glacier basin. The ability of the three methods used on a regional scale to estimate glacier contribution to a small, highly glacierised basin could therefore be assessed. The results were also compared to the observed streamflow from Peyto Glacier basin gauge 05DA008 which has a limited time series of data from May to October of 1967-1977. It is noted that the streamflow data from the first two years of operation are not reliable since these years are when the setting up of equipment and familiarisation with the monitoring process occurred (Shuster and Young 2006). A photograph of Peyto Glacier basin streamflow output in May 2007 and again in August 2008 can be found in Appendix B, with the majority of streamflow in May derived from snowmelt since the glacier was snow-covered, and in August derived from ice melt.

\subsubsection{Modelling Peyto Glacier basin streamflow with WATFLOOD}

Peyto Glacier basin was not included in the streamflow output gauging stations in the initial WATFLOOD setup. The WATFLOOD map file therefore had to be altered so that one grid element equalled the area of Peyto Glacier basin $\left(22.7 \mathrm{~km}^{2}\right)$, and the glacier cover in the grid element was set to the Landsat derived 1975 glacier cover in Peyto Glacier basin (63\%), with bare rock for the remaining area (a photograph of Peyto Glacier basin with Peyto Glacier at its 2008 extent can be found in Appendix B). The basin area and glacier cover initially in the Peyto grid element but not included in Peyto Glacier basin were subtracted from the Peyto grid element and added to the only grid element downstream in the Mistaya basin. WATFLOOD was then run from November 1972 (the earliest year of model streamflow files for the North Saskatchewan 
River basin) to 1985 with and without glaciers at their 1975 cover. This early time period was chosen to correspond with the observed streamflow data from Peyto Glacier basin, the short time period of which also limits the results from the hydrological-hypsometric approach to which the WATFLOOD results are compared. Peyto Glacier basin contains three glaciers, Peyto being the largest with an area of $13.6 \mathrm{~km}^{2}$ (1975), the other two glaciers having much smaller areas of 0.2 and $0.4 \mathrm{~km}^{2}$. Thus, when later comparing the WATFLOOD glacier contribution results with values of specific runoff from Peyto Glacier alone from previous research detailed in the literature, the glacier runoff contribution from these other two glaciers is considered negligible. After the model runs, the runoff from the Peyto grid element simulating Peyto Glacier basin was extracted and the difference between the simulated streamflow with and without glaciers for the July to September period was calculated as the combined glacier wastage and Melt.

\subsubsection{Hydrological-hypsometric approach}

The hydrological-hypsometric approach estimates combined glacier wastage and Melt as the difference in streamflow from July to September between a glacierised and non-glacierised basin of similar size and hypsometry, and with a common time period of observed hydrological data. The most similar basin to Peyto Glacier basin $\left(22.7 \mathrm{~km}^{2}\right)$ is Silverhorn basin $\left(21.0 \mathrm{~km}^{2}\right)$ located slightly northeast of Peyto Glacier basin (Figure 3.2). Unfortunately there is no similar,

non-glacierised basin in the region, and thus Silverhorn basin was used with $4 \%$ glacier cover to compare to Peyto Glacier basin. The two basins have a similar hypsometric integral of 0.565 (Peyto) and 0.584 (Silverhorn), and a common period of observed streamflow data from 19711977. A comparison of these two observed hydrographs has previously been made by Young (1991), but an estimate of glacier runoff was never calculated from the comparison. The 
difference in streamflow from July to September was calculated after converting each monthly average streamflow from $\mathrm{m}^{3} \mathrm{~s}^{-1}$ to $\mathrm{mm}$ to account for the difference in drainage areas.

\subsubsection{Volume- area relationship}

The volume-area relationship presented in equation 4.11 was used to calculate the net volume change of Peyto Glacier and the additional, relatively small glaciers in Peyto Glacier basin from 1975-1998. The sum of the net volume loss from each glacier was divided by the number of years to give the average wastage per year, and converted to $\mathrm{m}^{3}$ water equivalent. This is a big approximation since wastage will vary between years depending mainly on the climate, a yearly estimate, however, was required in order to compare the results with those from other methods of different length time periods.

\subsubsection{Mass balance data}

Mass balance data are available for Peyto Glacier, and data were selected from 19671977 from Young (1981) and Demuth and Keller (2006), to coincide with the available observed streamflow data. The net mass balance in $\mathrm{m}^{3}$ water equivalent is considered equivalent to the glacier wastage in negative balance years, an approach also used in Hopkinson and Demuth (2006). The summer mass balance in $\mathrm{m}^{3}$ water equivalent is considered equal to the combined glacier wastage and Melt (or solely Melt in positive net mass balance years) and snowmelt. It is

possible to calculate an estimate of ice melt from identifying the altitude of the equilibrium line (ELA), which is assumed equal to the snowline maximum, and summing the summer mass balance data below this altitude averaged over the glacier area below this altitude. 
There are errors associated with this since snowmelt in the ablation zone will still be included in this estimation, and the ELA is transient throughout the melt season so that the summer mass balance just below the ELA maximum will include more snowmelt runoff relative to lower in the ablation zone. The ELA is given alongside the mass balance measurements (Young 1981, Demuth and Keller 2006), but the ice melt calculated as summer mass balance below the ELA will depend how the ELA was defined. If the ELA provides a demarcation between ice and newly formed (one year old) firn, the estimated ice melt will be lower than if the ELA is defined as higher than this and there is a zone of firn below. The winter balance below the ELA provides an estimate of snow accumulation in the ablation zone, and on Peyto Glacier the average net winter mass balance was less than 1.5 metres (water equivalent) in the ablation zone, as averaged for the time period 1966-1978 by Young (1981). Whilst this is an estimation of snow accumulation on the ablation zone, it will also include any ice accumulation as a result of surface freezing or changes in glacier surface level due to movement of ice down the glacier, thus cannot all be attributed to snow accumulation. Another factor is that summer snow events, such as a large snowfall in late June, can have a great impact on the summer mass balance by covering the glacier ice with snow largely preventing ice melt until the snow melts. The summer mass balance below the ELA averaged over the ablation zone area therefore provides an estimate of combined glacier ice wastage and Melt (in negative mass balance years) to compare to the WATFLOOD and hydrological-hypsometric approach results, but it should be taken into consideration that the mass balance results are an overestimate of ice melt. 


\subsection{Glacier Contribution at Edmonton and Calgary Downstream}

The above sections have estimated the glacier wastage contribution and Melt impact on streamflow in the headwater basins where drainage areas are small and percentage basin glacier cover is large, relative to gauging stations further downstream. Whilst headwater streamflow provides a water supply for users located in this region - and also downstream in terms of industries such as hydroelectric power - the majority of the population on the North and South Saskatchewan Rivers lives further downstream making it useful to assess glacier contribution downstream from the headwaters. This is estimated using the WATFLOOD model and the volume-area method as previously described. Edmonton and Calgary in Alberta are large cities downstream that utilise water from the North Saskatchewan River and Bow River (a major tributary of the South Saskatchewan River), respectively, and are relatively close to the mountains (Figure 3.1). There are consistent streamflow records for the Bow River at Calgary (gauging station 05BH004) from 1911-2006, with a basin area of $7868.20 \mathrm{~km}^{2}$, and for the North Saskatchewan River at Edmonton (gauging station 05DF001), again from 1911-2006, with a basin area of $28077.10 \mathrm{~km}^{2}$. Using the volume-area approach, the net glacier wastage from 19751998 for the NSRB and for contributing SSRB sub-basins to the Bow River was found as a percentage of the total annual (glacier year) streamflow at Edmonton and Calgary respectively from 1975-1998. Glacier contribution for July to September was not estimated due to the regulation of streamflow, resulting in reduced peak spring and summer flows and increased winter flows which would affect the results. Calculating and assessing the importance of the annual percentage wastage contribution at Edmonton and Calgary, therefore, assumes that all water input to the reservoirs is discharged in a glacier year. This may, however, not be the case 
and there are also substantial water losses from reservoirs due to evaporation which would affect the relative percentage glacier contribution.

To estimate combined glacier wastage and Melt contribution at Edmonton and Calgary, the difference between the WATFLOOD simulated flows with and without glaciers from 19751998 for the furthest basins downstream on the North Saskatchewan and Bow Rivers was calculated and summed. The limitation of using this method is that glacier contribution is estimated for specific basins and not as a total for the entire headwater region. The furthest downstream basins modelled by WATFLOOD on the North Saskatchewan River are the North Saskatchewan at Whirlpool, Siffleur, and Ram River basins which together comprise $89 \%$ of the total glacier cover (as an average of the 1975 and 1998 cover) in the NSRB. The remaining glacier cover lies in the Clearwater, North Saskatchewan at Wilsons and Cline River basins. The furthest downstream modelled basins contributing to the Bow River at Calgary are the Bow at Banff and Cascade at Lake Minnewanka River basins. Together these comprise $71 \%$ of the total glacier cover (as an average of the 1975 and 1998 cover) in the Bow River basin, the remaining glacier cover lying mainly in the Spray and Kananaskis basins. Unfortunately, the WATFLOOD results could not be supplemented with results from the hydrological-hypsometric comparison approach since the latter could not be applied to any of these unmodelled basins containing glacier cover, mainly due to the lack of observed streamflow data. Since, in general, the greater the glacier cover of the basin, the stronger the glacial influence on streamflow (Chen and Ohmura 1990b), the WATFLOOD combined glacier wastage and Melt results were assumed to equal $89 \%$ and $71 \%$ of combined wastage and Melt contribution at Edmonton and Calgary respectively. The results were then extrapolated to give an estimate of wastage and Melt for the total $(100 \%)$ contributing glacier cover. The modelled combined glacier wastage and Melt was 
not found as a percentage of annual streamflow since glaciers do not contribute to increased total annual streamflow volume in terms of Melt. Instead, the difference between the wastage results (volume-area relationship) and combined wastage and Melt results (WATFLOOD) was calculated to give the volume of Melt that contributes to streamflow in the July to September months. This could not be found as a percentage of the July to September streamflow due to the regulation of flow, but this volume is important to seasonal streamflow since this is the volume of water that currently reaches Calgary and Edmonton in July to September, but would arrive in the May and June snowmelt months if the glaciers did not exist (under the same climate regime, assuming all the snow that would have fallen on the glaciers melts, and assuming post-glacial basin conditions do not delay snowmelt runoff). 


\section{Chapter 5}

\subsection{Results and Analysis}

\subsection{Glacial Impact on Streamflow in the $\mathrm{N}$ and SSRB Headwaters}

A comparison of observed streamflow hydrographs from glacierised and non-glacierised basins from 1976-1992 was made to determine the impact of glacier runoff on streamflow. For some basins, the annual coefficient of variation $(\mathrm{CV})$ could not be calculated due to the lack of observed streamflow records for the winter months. The percentage basin glacier cover for 1976 and 1992 used as a reference in Table 5.1 is an estimate, and is calculated by assuming a linear decline in glacier cover between 1975 and 1998. It is unlikely that glacier cover declines linearly (section 2.2.3), but this approach was necessary due to the lack of additional glacier cover data. 
Table 5.1 Mean observed monthly flow as a percentage of the total June to October flow volume, and $C V$ for mean annual and July to September flows from 1976-1992

Source data: HYDAT (Environment Canada WSC: HYDAT)

\begin{tabular}{|c|c|c|c|c|c|c|c|c|c|}
\hline \multirow[t]{2}{*}{ Station Gauge Name } & \multicolumn{5}{|c|}{$\begin{array}{l}\text { Monthly contribution to total flow } \\
\text { Jun-Oct \% }\end{array}$} & \multicolumn{2}{|l|}{$C V$} & \multicolumn{2}{|c|}{$\begin{array}{l}\text { Glacier cover } \\
\%\end{array}$} \\
\hline & Jun & Jul & Aug & Sept & Oct & $\begin{array}{l}\text { Jul- } \\
\text { Sept }\end{array}$ & Annual & 1976 & 1992 \\
\hline $\begin{array}{l}\text { North Saskatchewan at } \\
\text { Whirlpool } \\
\text { Mistaya near }\end{array}$ & 23.67 & 31.12 & 27.89 & 12.52 & 4.80 & 0.15 & 0.09 & 16.09 & 14.35 \\
\hline Saskatchewan crossing & 24.47 & 31.39 & 26.15 & 12.76 & 5.24 & 0.15 & 0.08 & 13.38 & 11.50 \\
\hline Bow at Lake Louise & 28.52 & 30.95 & 23.46 & 11.77 & 5.31 & 0.18 & & 9.31 & 7.85 \\
\hline Siffleur & 30.08 & 31.42 & 21.14 & 11.66 & 5.69 & 0.23 & & 5.20 & 3.53 \\
\hline Silverhorn & 33.45 & 34.80 & 17.32 & 9.79 & 4.64 & 0.32 & 0.18 & 4.03 & 2.84 \\
\hline Bow at Banff & 33.71 & 29.21 & 19.10 & 11.29 & 6.69 & 0.23 & 0.14 & 3.35 & 2.51 \\
\hline Red Deer above Panther & 29.86 & 27.96 & 22.30 & 12.43 & 7.45 & 0.22 & & 3.06 & 2.36 \\
\hline Spray at Banff & 31.46 & 24.38 & 18.35 & 14.59 & 11.22 & 0.17 & 0.16 & 1.27 & 0.86 \\
\hline Clearwater & 27.30 & 27.60 & 21.07 & 14.27 & 9.76 & 0.29 & & 1.28 & 0.93 \\
\hline \multicolumn{10}{|l|}{ Red Deer below Burnt } \\
\hline Timber Creek & 31.24 & 27.00 & 20.66 & 12.73 & 8.37 & 0.28 & 0.24 & 1.28 & 1.00 \\
\hline Brewster & 44.37 & 29.11 & 13.47 & 8.13 & 4.91 & 0.35 & & 1.16 & 0.53 \\
\hline Johnston & 42.34 & 28.17 & 14.55 & 9.31 & 5.63 & 0.33 & & 0.59 & 0.38 \\
\hline Casdade & 38.14 & 27.07 & 16.84 & 10.64 & 7.31 & 0.28 & & 0.58 & 0.23 \\
\hline Ram River & 31.74 & 28.36 & 17.57 & 13.02 & 9.31 & 0.39 & 0.29 & 0.29 & 0.15 \\
\hline Highwood at Diebels & 47.64 & 23.24 & 13.08 & 8.84 & 7.19 & 0.35 & & 0.19 & 0.06 \\
\hline \multicolumn{10}{|l|}{ Elbow above Elbow } \\
\hline Falls & 35.67 & 23.66 & 17.16 & 12.93 & 10.58 & 0.27 & & 0.10 & 0.05 \\
\hline Ghost River & 37.01 & 24.99 & 17.83 & 11.84 & 8.33 & 0.32 & & 0.04 & 0.01 \\
\hline Goat Creek & 18.25 & 20.94 & 24.76 & 21.71 & 14.33 & 0.32 & 0.34 & 0.00 & 0.00 \\
\hline Cataract & 52.59 & 21.42 & 11.82 & 7.85 & 6.32 & 0.46 & 0.35 & 0.00 & 0.00 \\
\hline North Ram & 31.19 & 30.66 & 16.98 & 12.49 & 8.69 & 0.45 & & 0.00 & 0.00 \\
\hline Deer Creek sundre & 29.20 & 30.98 & 17.09 & 11.53 & 11.20 & 0.76 & & 0.00 & 0.00 \\
\hline
\end{tabular}

\subsubsection{Observed streamflow hydrograph analysis}

Figure 5.1 below plots the monthly percentage flow contribution of each month to the total June to October flow based on a common period of flow data 1976-1992 for a) glacierised $(>3 \%)$, b) part glacierised $(0.5 \%-3 \%)$ and c) non-glacierised basins $(<0.5 \%)$ from the results in Table 5.1. Initially, the results were plotted in one figure, and then these ranges chosen to separate the plots based on the flow differences observed. The percentage glacier cover in Figure 5.1 is the average of the 1976 and 1992 interpolated glacier cover. 


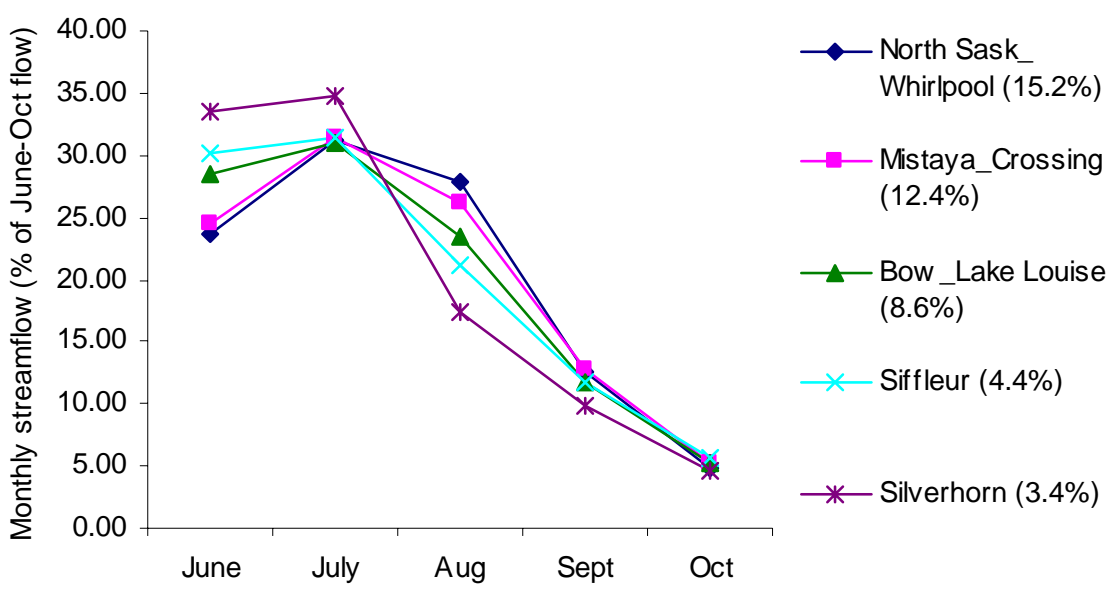

a) Glacierised basins (above 3\% glacier cover)

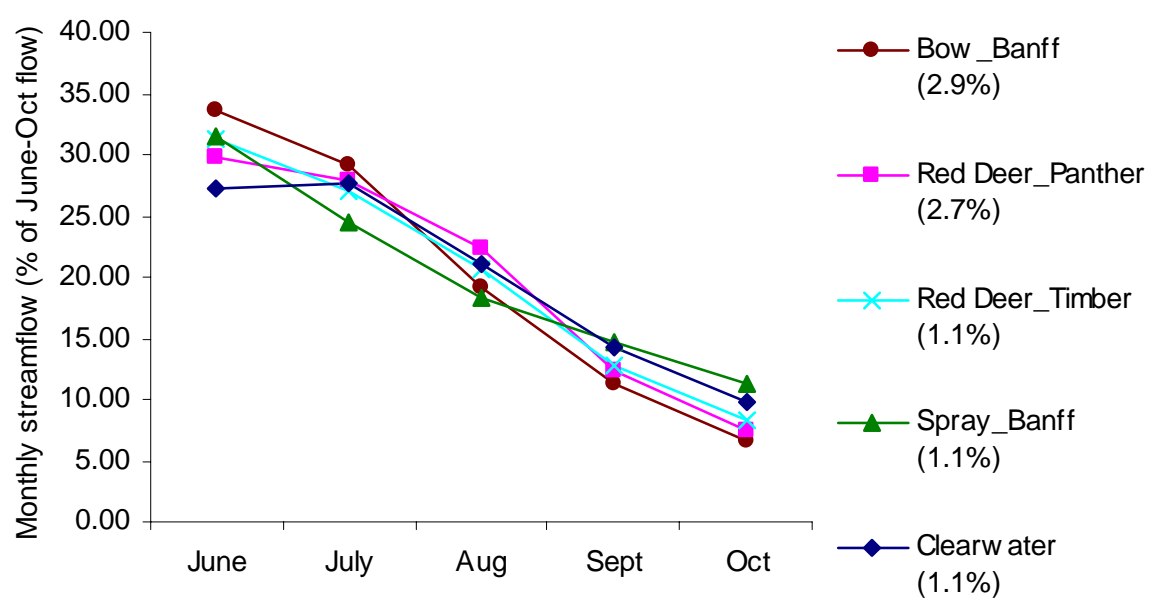

b) Partly glacierised basins (between $0.5 \%$ and $3 \%$ glacier cover)

Figure 5.1 Monthly observed streamflow as a percentage of the June to October streamflow for basins of differing glacier covers. Percentage basin glacier cover is given in parenthesis. 
Figure 5.1 continued

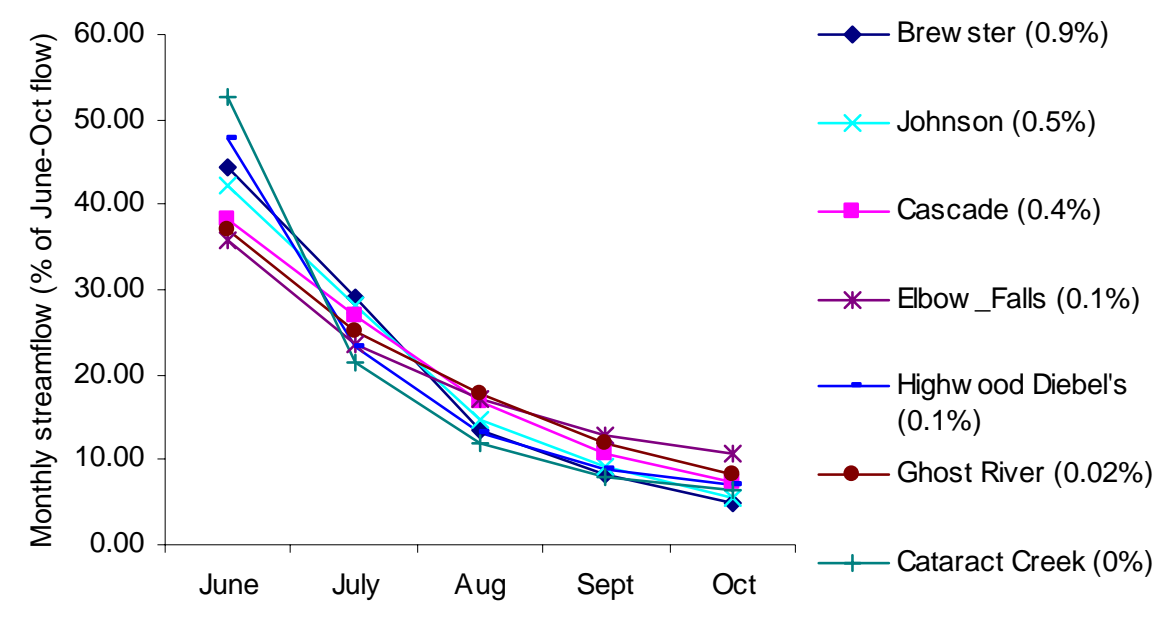

c) Non-glacierised basins (less than $0.5 \%$ glacier cover)

Figure 5.1 shows how the monthly flow contribution to the total June to October flow differs among the headwater basins analysed according to the basin glacier cover. Basins with over $3 \%$ glacier cover such as Mistaya River near Saskatchewan Crossing (12.4\%) have peak flows in July with flows later in the summer also relatively high compared to non-glacierised basins. Non-glacierised basins, such as Cataract Creek do not show any glacier augmentation effect in the summer period with peak flows in June and a sharp drop in discharge in July. Basins with small glacier cover (between 0.5 and $3 \%$ ) such as Red Deer River at Panther $(2.7 \%)$ also have peak flows in June, but show a slight glacier augmentation effect with a more gradual drop in the discharge through July and August. In addition, in some cases it was observed that the glacier augmentation effect decreased with an increase in basin contribution area. For example, Silverhorn $\left(21 \mathrm{~km}^{2}\right)$ and the Bow River at Banff $\left(2209.6 \mathrm{~km}^{2}\right)$ basins have similar glacier cover (3.4\% and $2.9 \%$ respectively), but different flow contribution patterns with Silverhorn having a later peak flow in July. Caution should be taken, however, when attributing the difference in the late summer flows to solely glacier augmentation and there are anomalies such as Clearwater 
basin ( $1.1 \%$ glacierised) which has a peak flow in July (Figure $5.1 \mathrm{c})$, and the Ram $(0.2 \%$ glacierised), North Ram ( $0 \%$ glacierised) and Deer Creek ( $0 \%$ glacierised) basins which have similar flows in June and July (Table 5.1), suggesting that other factors are augmenting or causing delayed basin runoff. Higher elevated basins, generally those containing glaciers, will have greater snowfall and some of the late summer streamflow may consist of late snowmelt runoff. In addition, lower elevated basins, generally the less glacierised or non-glacierised basins, are likely to have a greater proportion of forest cover which affects snow accumulation and melt, and in general reduces streamflow runoff. The differences in late summer flows between glacierised and non-glacierised basins can therefore not be solely attributed to the percentage glacier cover.

\subsubsection{Streamflow coefficient of variation}

The streamflow coefficient of variation $(\mathrm{CV})$ for the July to September period and (where possible) annually for those basins with a common period of data (1976-1992) was calculated (Table 5.1). Figure 5.2 shows the variation in $C V$ with basin glacier cover, the trend line applies to the glacierised basins (above $0.5 \%$ ) only. 


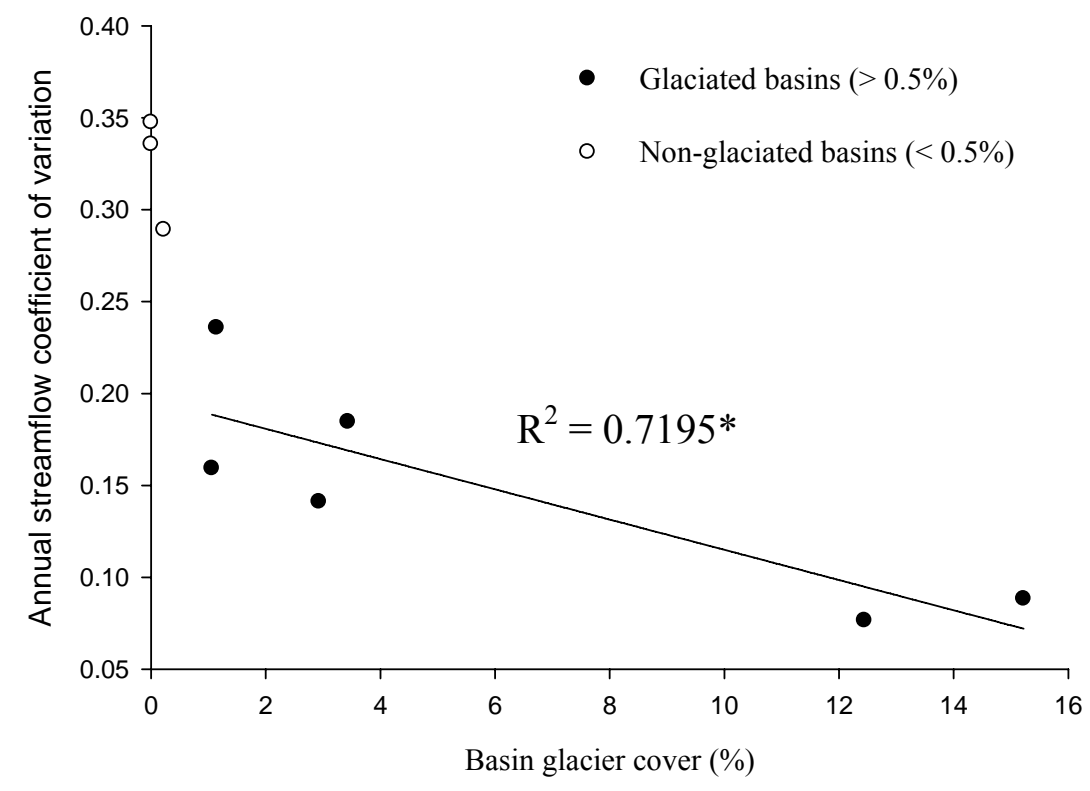

a) Annual streamflow

* significant at $\alpha=0.05$

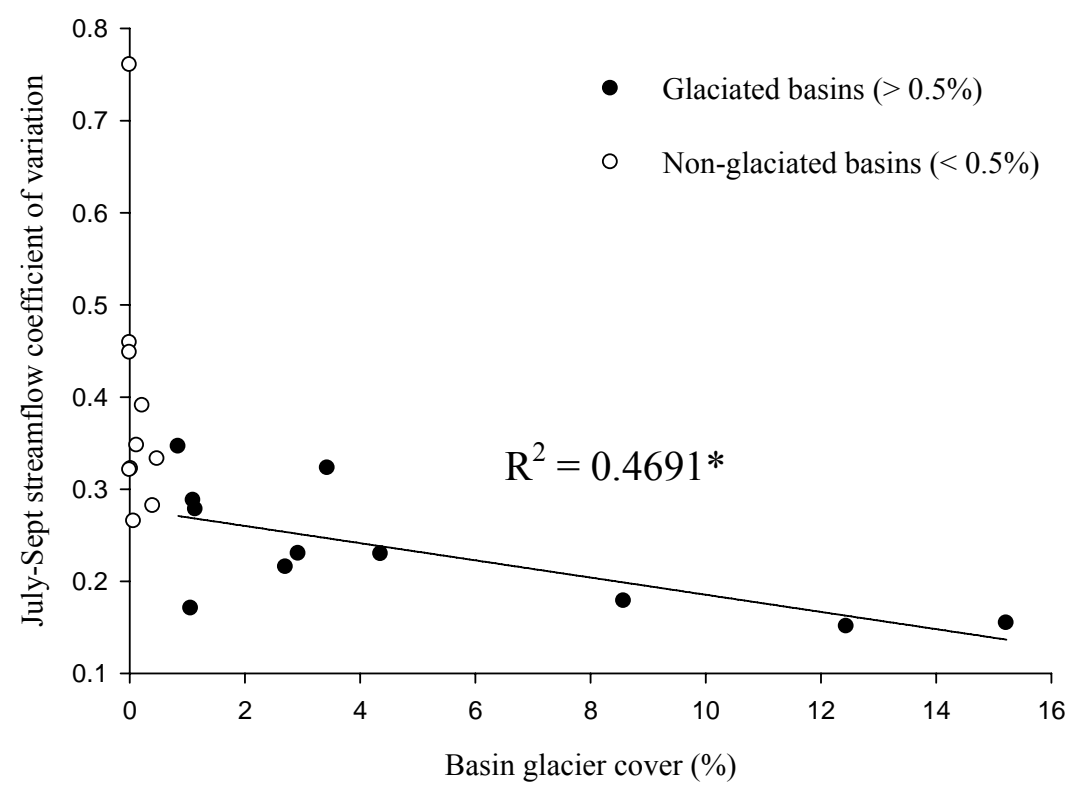

b) July-September streamflow

* significant at $\alpha=0.05$

Figure 5.2 Variation of observed streamflow coefficient of variation, a) annual b) July to September, with percentage basin glacier cover for N and SSRB headwater basins from 19761992 
Annual $C V$ (only possible to calculate for nine basins due to the lack of available hydrometric flow data) decreases with increasing glacier cover from 0.35-0.08 for a glacier cover range of $0-15.2 \%$ (Table 5.1). Similarly, the July to September $C V$ decreases from $0.76-0.15$ for the same glacier cover range, and from $0.35-0.15$ for glacierised basins (above $0.5 \%$ glacier cover) but with a weaker trend. This analysis was completed for a large range of basin sizes varying from $21.0-2244.0 \mathrm{~km}^{2}$. The results show that the streamflow coefficient of variation both annually and in the July to September period decreases with increasing basin glacier cover.

\subsection{Climate Variations from 1975-1998}

Glacier contribution to streamflow is estimated for two time periods corresponding with the available glacier cover data for 1975 and 1998. When comparing the results for the ten year time periods surrounding these two years, knowledge of the climate is required since variations in glacier contribution cannot solely be attributed to change in glacier cover. In a warm, dry year glacier contribution will comprise a greater proportion of streamflow. This is due to increased glacier ice melt as a result of increased energy for melt, and a longer time period over which the glacier ice is exposed due to less snowfall and an increased rate of snowmelt. In addition, the decreased late summer streamflow as a result of lack of precipitation and increased evaporation will increase the relative proportion of streamflow contributed by glaciers. Therefore the average monthly rainfall, snowfall and mean temperature from three meteorological stations in the $\mathrm{N}$ and SSRB region with long, continuous time periods of data were calculated and plotted below

(Figure 5.3). The meteorological stations used were Banff, Jasper and Lake Louise, which were also used to provide climate data for the WATFLOOD model runs, and are shown in Figure 4.6. 


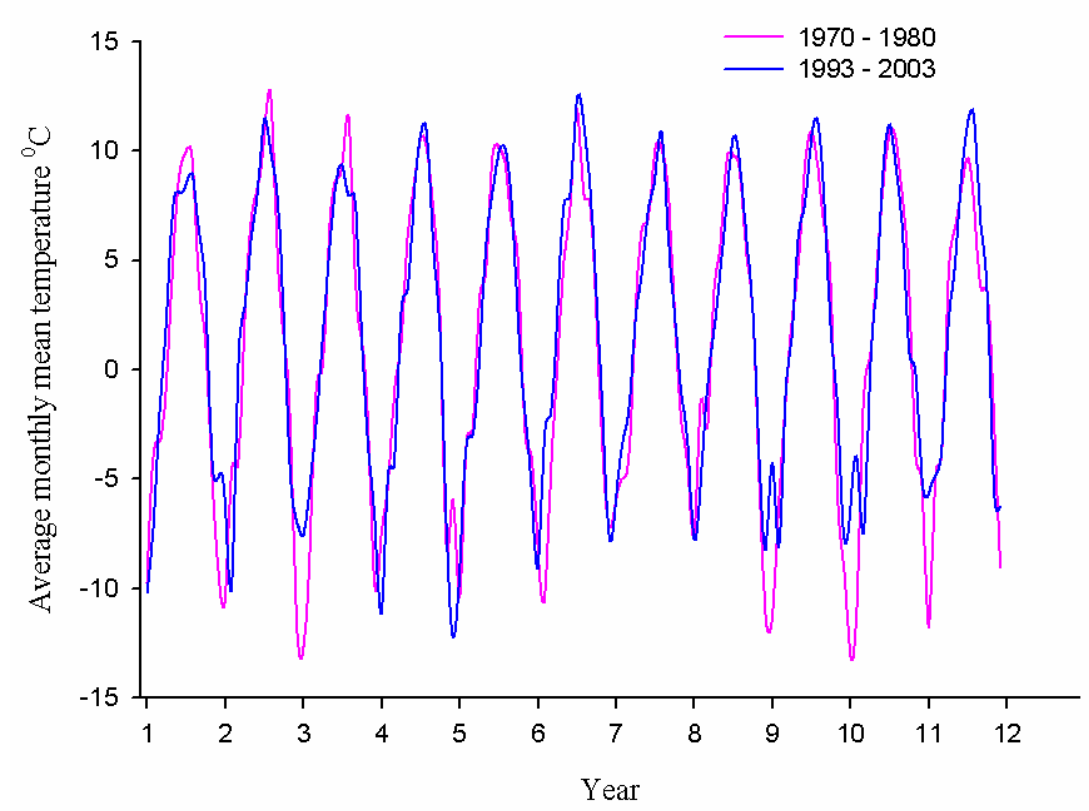

a) Average monthly mean temperature

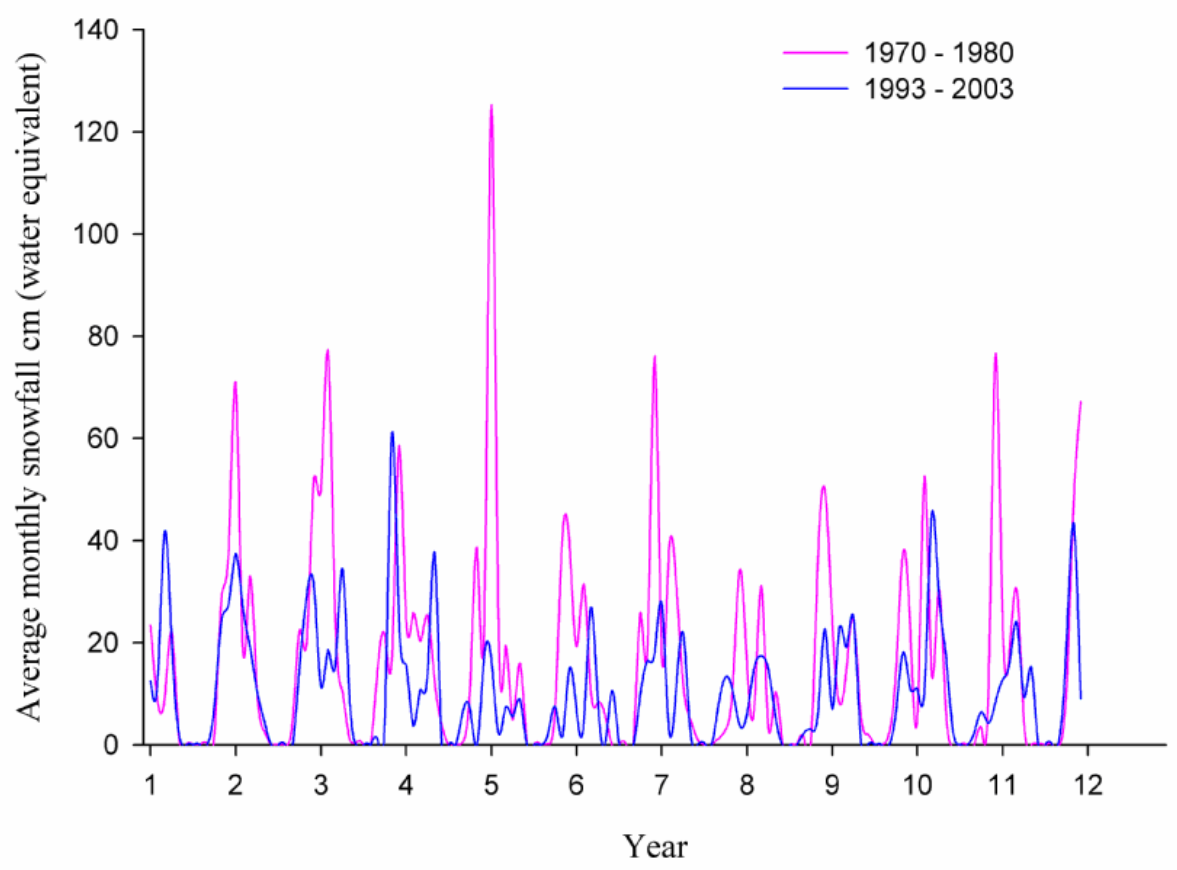

b) Average monthly snowfall

Figure 5.3 Monthly climate data for 1970-1980 and 1993-2003 as an average of the climate data recorded at Lake Louise, Jasper and Banff, for a) mean temperature b) snowfall and c) rainfall. 
Figure 5.3 continued

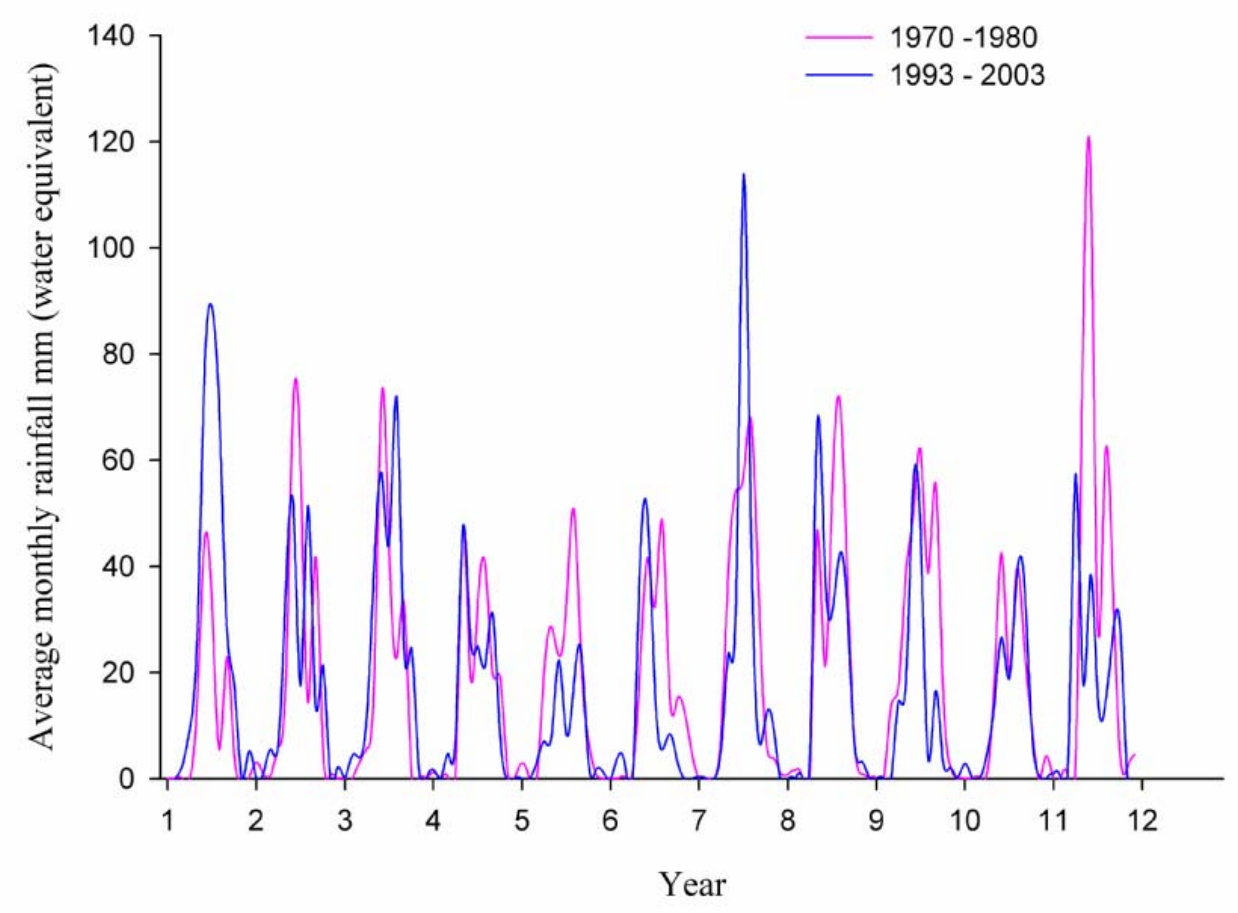

c) Average monthly rainfall

The summary data for Figure 5.3 are given in Table 5.2, showing the differences between the monthly climate variables averaged for the winter months (November to April) and summer months (May to October) between 1970-1980 and 1993-2003. 
Table 5.2 Differences between climate variables averaged for the winter and summer months between 1970-1980 and 1993-2003, as an average of the Banff, Lake Louise and Jasper meteorological station data

\begin{tabular}{|c|c|c|c|c|c|c|}
\hline \multirow[t]{2}{*}{ Climate variable } & \multicolumn{3}{|l|}{ Winter } & \multicolumn{3}{|l|}{ Summer } \\
\hline & $1970-80$ & 1993-03 & Difference & $1970-80$ & $1993-03$ & Difference \\
\hline Mean temperature $(\mathrm{K})$ & 268.37 & 269.18 & $0.81 \mathrm{~K}$ & 280.33 & 280.38 & $0.05 \mathrm{~K}$ \\
\hline Snowfall (cm w.e.) & 29.62 & 17.22 & $-42 \%$ & 3.43 & 3.75 & $9.1 \%$ \\
\hline Rainfall (mm w.e.) & 2.09 & 3.09 & $48 \%$ & 35.00 & 30.69 & $-12 \%$ \\
\hline
\end{tabular}

From Figure 5.3 and Table 5.2 it can be seen that the major differences in the climate variables between the 1970-1980 time period and the 1993-2003 period were in the winter months. Mean winter temperature had increased by $0.81 \mathrm{~K}$ in the $1993-2003$ period and snowfall decreased by $42 \%$ relative to the $1970-1980$ period. Higher winter temperatures would decrease the proportion of precipitation that falls as snow on the glacier (winter rainfall had increased by $48 \%$ in the 1993-2003 period) which, combined with decreased snowfall, results in earlier exposure of the glacier ice with a faster retreat of the snowline, thus increasing ice melt in the summer. For the summer climate, there was a very small difference of $0.05 \mathrm{~K}$ between the mean temperatures for both time periods, and the snowfall was minimal with a small percentage increase of $9 \%$ for the $1993-2003$ period relative to the $1970-1980$ period. The greatest difference was in the summer rainfall which had decreased by $12 \%$ in the $1993-2003$ period relative to the 1970-1980 period. Decreased summer rainfall would result in decreased summer basin runoff in the 1993-2003 period, thus if glacier runoff was equal in volume for both time periods, it would contribute a larger proportion of streamflow in the 1993-2003 period. In addition, the input of relatively warm rainfall to the glacier surface in summer generally results in increased ice melt during the rain event. Therefore, if glaciers were to remain at their 1975 glacier cover, the proportion of glacier contribution to streamflow would generally be expected to increase in the $1993-2003$ period relative to the $1970-1980$ period due to changes in climate. 


\subsection{Modelling Glacier Wastage and Melt with WATFLOOD}

The results of the Nash-Sutcliffe and Mean Bias Differences calculations as an indication of the ability of WATFLOOD to simulate streamflow are shown in Table 5.3 below, with the percentage basin glacier cover (1975).

Table 5.3 Results of Nash-Sutcliffe model efficiency $\left(\mathrm{R}^{2}\right)$ and Mean Bias Differences (MBD) analysis for modelled basins of the $\mathrm{N}$ and SSRB

\begin{tabular}{llrr}
\hline Basin & $\begin{array}{l}\text { Basin glacier } \\
\text { cover (\%) }\end{array}$ & R $^{2}$ & MBD \\
\hline North Saskatchewan River Basin & & & \\
Mistaya at Saskatchewan Crossing & 13.5 & 0.72 & -0.38 \\
Silverhorn & 4.1 & 0.42 & -0.10 \\
North Saskatchewan at Whirlpool & 16.2 & 0.84 & 0.30 \\
Siffleur & 5.3 & 0.72 & -0.98 \\
North Ram & 0.0 & 0.39 & -0.13 \\
Ram at Mouth & 0.3 & 0.64 & 1.77 \\
South Saskatchewan River Basin & & & \\
Bow at Lake Louise & 9.4 & 0.78 & 1.05 \\
Pipestone & 4.3 & 0.74 & -0.34 \\
Johnston & 0.6 & 0.76 & 0.56 \\
Bow at Banff & 3.4 & 0.83 & $\mathbf{1 0 . 5 6}$ \\
Brewster & 1.2 & 0.68 & 0.25 \\
Redearth near Mouth & 2.9 & 0.43 & $\mathbf{2 . 9 8}$ \\
Spray at Banff & 1.3 & -11 & $\mathbf{- 3 . 3 8}$ \\
Goat Creek & 0.0 & -1.2 & 0.47 \\
Cascade above Lake Minnewanka & 0.6 & 0.73 & 1.17 \\
Bow near Seebe & 2.2 & 0.37 & $\mathbf{3 1 . 4 0}$ \\
\hline
\end{tabular}

Plots of the simulated and observed streamflow hydrographs for the time period of analysis surrounding 1975 (which varied depending on the availability of observed streamflow data) can be found in Appendix A. 


\subsubsection{Results of the Nash Sutcliffe analysis}

Basins with a greater percentage glacier cover (above 5\%) in the North Saskatchewan River basin were well simulated with an $\mathrm{R}^{2}$ of above 0.7 (indicated in blue in Table 5.3). Lesser glacierised basins, however, were poorly simulated (less than $0.5 \mathrm{R}^{2}$ ) with the exception of the Ram River basin ( $0.3 \%$ glacierised) with an $\mathrm{R}^{2}$ of 0.64 (indicated in pink in Table 5.3). Similarly, for the South Saskatchewan River basin the greater glacierised basins (above 3\% glacierised) and also the Johnston River and Cascade at Lake Minnewanka basins (both 0.6\% glacierised) were well simulated with an $\mathrm{R}^{2}$ of above 0.7 (indicated in blue in Table 5.3), and the other lesser glacierised basins poorly modelled, with the exception of Brewster with an $\mathrm{R}^{2}$ of 0.68 (indicated in pink in Table 5.3). Both Goat Creek and Spray River at Banff basins have negative $\mathrm{R}^{2}$ values, for Goat Creek this may be due to the very low streamflow rate in all months of the year with an average of approximately $1 \mathrm{~m}^{3} \mathrm{~s}^{-1}$ in July to September. Also, the flow of Goat Creek and the Spray River at Banff is regulated thus the WATFLOOD modelled natural flow displays differences. Similarly, the poor result for the Bow River near Seebe $\left(\mathrm{R}^{2}\right.$ of 0.37 ) is likely due to the regulation of flow. It is not possible to identify the specific reason for the poor Nash-Sutcliffe result in each basin, but these poorly modelled basins with an $\mathrm{R}^{2}$ of less than 0.6 are not used in the subsequent estimation of glacier contribution since the model does not simulate observed streamflow accurately.

\subsubsection{Results of the Mean Bias Differences (MBD) analysis}

For the majority of basins in the N and SSRB the MBD was low at between -1 and 1 , indicating that there was a small amount of long term over and underestimation in the simulated streamflow, and that the model performed well. The model does not appear to consistently over 
or underestimate observed streamflow between basins since there are approximately equal positive and negative MBD values for the different basins. Those basins with a poor MBD value are highlighted in bold in Table 5.3, the majority of which also had poor Nash-Sutcliffe results, these are Redearth near the Mouth $\left(\mathrm{MBD}=2.98, \mathrm{R}^{2}=0.43\right)$, Spray at Banff $\left(\mathrm{MBD}=-3.38, \mathrm{R}^{2}=\right.$ $-11)$, and the Bow near Seebe $\left(M B D=31.40, \mathrm{R}^{2}=0.37\right)$. The poor MBD results for the Spray at Banff and Bow near Seebe are likely the result of the regulation of the natural flow in these basins. The Bow River at Banff also has a poor MBD (10.56) meaning that the model systematically underestimated streamflow from this basin, however, the Nash-Sutcliffe result (0.83) indicates that the model accurately simulated streamflow. The high MBD may be due to the consistent underestimation by the model of the winter streamflow from this basin, shown in the plotted simulated and observed streamflow graph for the Bow River at Banff in Appendix A. Therefore, whilst the results for the Bow River at Banff have been analysed in this thesis due to the high Nash-Sutcliffe result and the poor simulation indicated by the high MBD manifest mainly in the winter months in which glacier contribution is not analysed, caution must be taken regarding the results from this basin as the high MBD value indicates that the model underestimates streamflow.

\subsubsection{Observations of the observed and WATFLOOD simulated hydrographs}

The observed and simulated hydrographs (displayed in Appendix A) from the basins with an $\mathrm{R}^{2}$ of above 0.6 were generally well matched in the timing and magnitude of the peak flow. For the North Saskatchewan River basin, the simulated peak flow from the Silverhorn, North Saskatchewan at Whirlpool and Ram River basins was smaller in magnitude than the observed flow for the majority of years, Silverhorn and Ram being considerably smaller in years of high 
observed flow, hence the lower $\mathrm{R}^{2}$ values. Simulated peak flows for the Mistaya at Saskatchewan Crossing, Siffleur and North Ram River basins were both smaller or greater than the observed flow in different years, the North Ram being considerably different, hence the low $\mathrm{R}^{2}$ value. The timing of the peak flow appears to be better modelled than the magnitude, and was both slightly earlier and later than the observed flow for all the basins analysed in the NSRB, expect for Silverhorn basin for which the simulated peak flow was generally earlier than the observed, further lowering the low $\mathrm{R}^{2}$ value.

For the South Saskatchewan River basin, again the differences in magnitude were greater than the differences in timing between the simulated and observed peak flows. The Bow at Lake Louise, Bow at Banff, Pipestone and Cascade at Lake Minnewanka simulated basin flows were both slightly greater and smaller in magnitude than the observed flow. Brewster, Goat Creek and Bow at Seebe simulated peak flows, however, differed considerably (both greater and smaller) from the observed flow, especially for the latter two basins, hence the low $\mathrm{R}^{2}$ values. Johnston Creek had a lower simulated peak flow in years of high flow, but was otherwise similar to the observed flow. Redearth Creek, however, had peak flows that were considerably lower than the observed flows hence the lower $\mathrm{R}^{2}$ values. The only basin to have higher simulated peak flows than the observed flow was the Spray at Banff, in which case the observed flow had a more constant summer flow without a clearly defined peak, the result of flow regulation. Another difference due to the regulation of flow is the high base flows observed for the Bow River at Seebe, for which the simulated flow was much lower, again lowering the $\mathrm{R}^{2}$ value. In terms of timing for the South Saskatchewan River basin, all the basins except Goat Creek had simulated streamflow which was both slightly earlier and later than the observed flow for differing years, Brewster having a greater difference than the rest. In general, the simulated flow for Goat Creek 
had earlier peak flows, though this is difficult to determine since the observed peak flows were not clearly defined for some years, which may be due to the very low discharge in this small, nonglacierised basin, or due to the regulation of flow.

Overall it appears that the model accurately simulated the timing of the peak flow, indicating that the routing parameters are well calibrated. The differences in observed and simulated flow appear to result mainly from differences in the magnitude of the peak flow indicating problems with the land cover class parameters. This separation of poorly and well modelled basins by glacier cover is likely due to the focus of the initial calibration on the glacier and snowmelt parameters. Full recalibration of the model using the Dynamically Dimensioned Search (DDS) automated algorithm (Tolson and Shoemaker 2007) is currently underway but is not part of this thesis.

\subsubsection{Modelled glacier wastage and seasonal Melt contribution}

Examples of WATFLOOD simulated hydrographs with and without glaciers at the 1998 glacier cover, and compared to the observed flow are shown in Figure 5.4 below for two large basins in the N and SSRB from 1993-2003. The North Saskatchewan River at Whirlpool has a much greater percentage basin glacier cover (13.7\%) than the Bow River at Banff $(2.2 \%)$, which is typical of the $\mathrm{N}$ and SSRB headwater basin glacier cover differences. This variation in basin glacier cover is reflected in the difference between the simulated streamflow with and without glaciers, which is very large for the North Saskatchewan River at Whirlpool, but smaller and only noticeable in the falling limb of the hydrograph in the late summer months for the Bow River at Banff. 

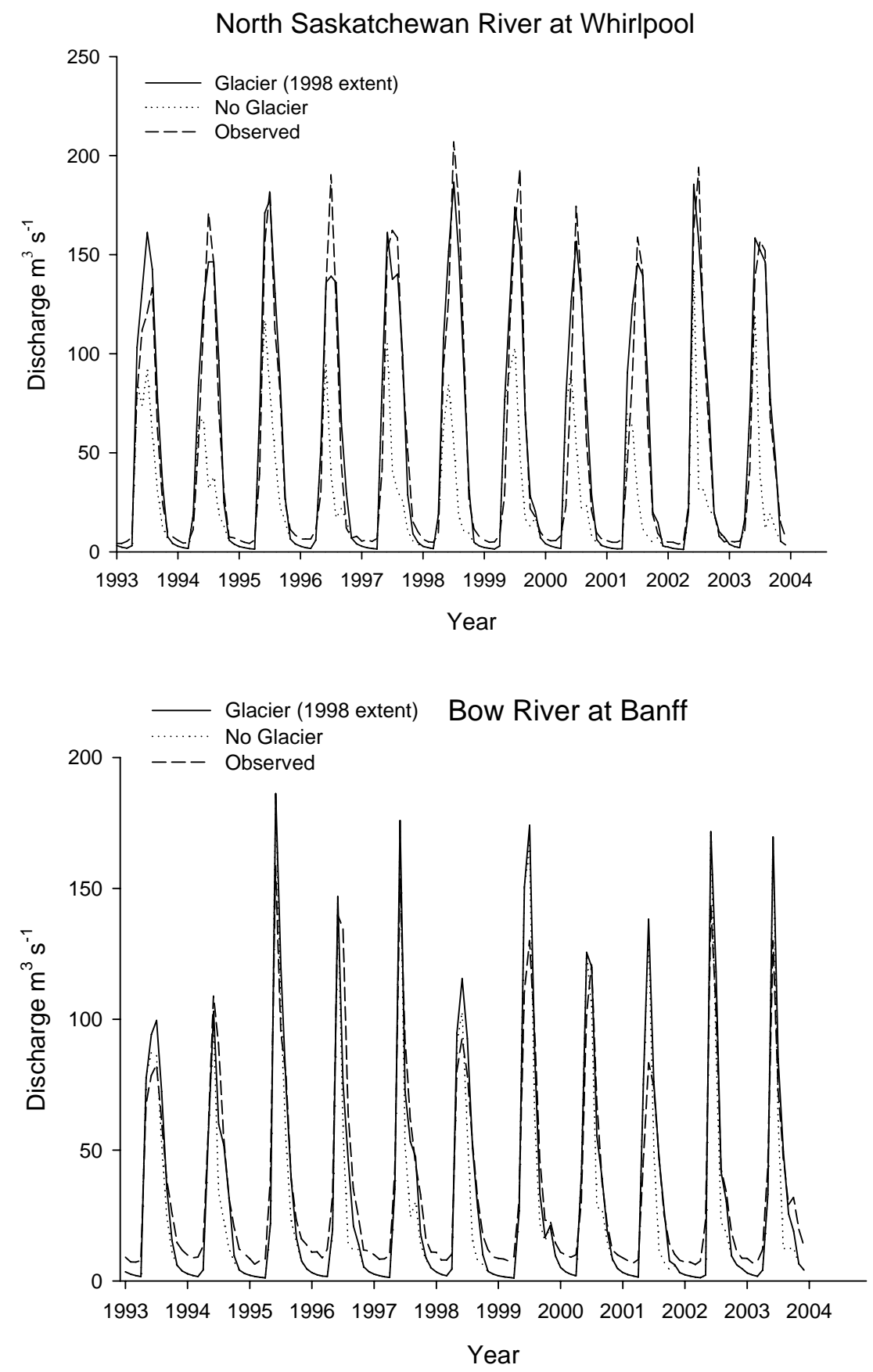

Figure 5.4 WATFLOOD simulated (with and without glaciers at the 1998 cover) and observed streamflow for the North Saskatchewan River at Whirlpool and the Bow River at Banff from 1993-2003 
The difference in simulated streamflow with and without glaciers for July to September was calculated as a percentage of the simulated flow with glaciers to give an estimation of seasonal combined glacier wastage and Melt contribution to streamflow (Table 5.4). This was calculated for two time periods using the 1975 glacier cover (1970-1980 SSRB and 1972-1982 NSRB) and the 1998 glacier cover (1993-2003). Note that those basins with Nash-Sutcliffe model efficiency $\mathrm{R}^{2}$ of less than 0.6 are omitted from this calculation, as discussed in the analysis of the Nash-Sutcliffe results (section 5.3.1).

Table 5.4 Modelled percentage combined glacier wastage and Melt contribution to July to September streamflow for basins of the N and SSRB

\begin{tabular}{llll}
\hline Basin & $\begin{array}{l}\text { Time } \\
\text { period }\end{array}$ & $\begin{array}{l}\text { Basin } \\
\text { glacier } \\
\text { cover (\%) }\end{array}$ & $\begin{array}{l}\text { Glacier } \\
\text { contribution \% } \\
\text { July-Sept }\end{array}$ \\
\hline North Saskatchewan River Basin & $1972-1982$ & 13.5 & 79 \\
Mistaya River near Sask Crossing & $1993-2003$ & 10.8 & 77 \\
& $1972-1982$ & 16.2 & 81 \\
North Sask River at Whirlpool Point & $1993-2003$ & 13.7 & 73 \\
& $1972-1982$ & 5.3 & 55 \\
Siffleur River near the mouth & $1993-2003$ & 2.9 & 37 \\
& $1972-1982$ & 0.3 & 6 \\
Ram River near the mouth & $1993-2003$ & 0.1 & 0 \\
& $1972-1982$ & 20.2 & 83 \\
North Sask River at Sask Crossing & $1993-2003$ & 17.6 & 76 \\
& & & \\
South Saskatchewan River Basin & $1970-1980$ & 9.4 & 73 \\
Bow River at Lake Louise & $1993-2003$ & 7.3 & 67 \\
& $1970-1980$ & 4.3 & 64 \\
Pipestone River near Lake Louise & $1993-2003$ & 2.2 & 46 \\
& $1970-1980$ & 0.6 & 34 \\
Johnston Creek near the mouth & $1993-2003$ & 0.2 & 7 \\
& $1970-1980$ & 3.4 & 58 \\
Bow River at Banff & $1993-2003$ & 2.2 & 41 \\
& $1970-1980$ & 1.2 & 26 \\
Brewster River near Banff & $1993-2003$ & 0.3 & 0 \\
& $1970-1980$ & 0.6 & 7 \\
Cascade River above Lake & & & \\
Minnewanka & $1993-2003$ & 0.1 & 3 \\
& & & \\
\hline
\end{tabular}


With reference to Table 5.4, combined glacier wastage and Melt contribution to streamflow modelled by WATFLOOD was very high in the late summer months (July to September), with percentage contribution ranging from $73-83 \%$ for basins with glacier cover above $10 \%$, and from $26-73 \%$ for basins with between 1 and $10 \%$ glacier cover. Glacier contribution for basins with less than $1 \%$ glacier cover was less than $10 \%$, with the exception of Johnston Creek in the 1970-1980 time period with 34\% contribution, which, however, dropped to $7 \%$ in the 1993-2003 time period. This indicates that combined glacier wastage and Melt is an important contributor to streamflow in the July to September period when basin glacier cover is above $1 \%$ in these headwater basins. In the South Saskatchewan River basin, none of the basins analysed had above $10 \%$ glacier cover, of which the Bow at Lake Louise had the greatest glacier cover of $7.3 \%$ (1998). This is reflected in the glacier contribution percentages to the Bow River at Lake Louise which are more similar to those found in the greater glacierised basins of the North Saskatchewan River basin. From 1970-1980 to 1993-2003 the average glacier contribution in July to September in the modelled headwater basins in the South Saskatchewan River basin decreased from $44-27 \%$, and from $61-53 \%$ in the North Saskatchewan River basin (from 19721982 to 1993-2003). Before attributing this decrease in glacier contribution to the decrease in glacier cover from 1975-1998, changes in the average climate for the two time periods must be considered. With reference to section 5.2, the average drier summer and warmer winters with decreased snowfall for the 1993-2003 time period relative to the 1970-1980 period would be expected to result in increases in glacier contribution if glacier cover was kept constant, implying that the decrease in modelled glacier contribution is the result of a decrease in glacier cover from 1975-1998. The relationship between basin glacier cover and seasonal combined glacier wastage and Melt contribution to flow as modelled by WATFLOOD is displayed in Figure 5.5. 


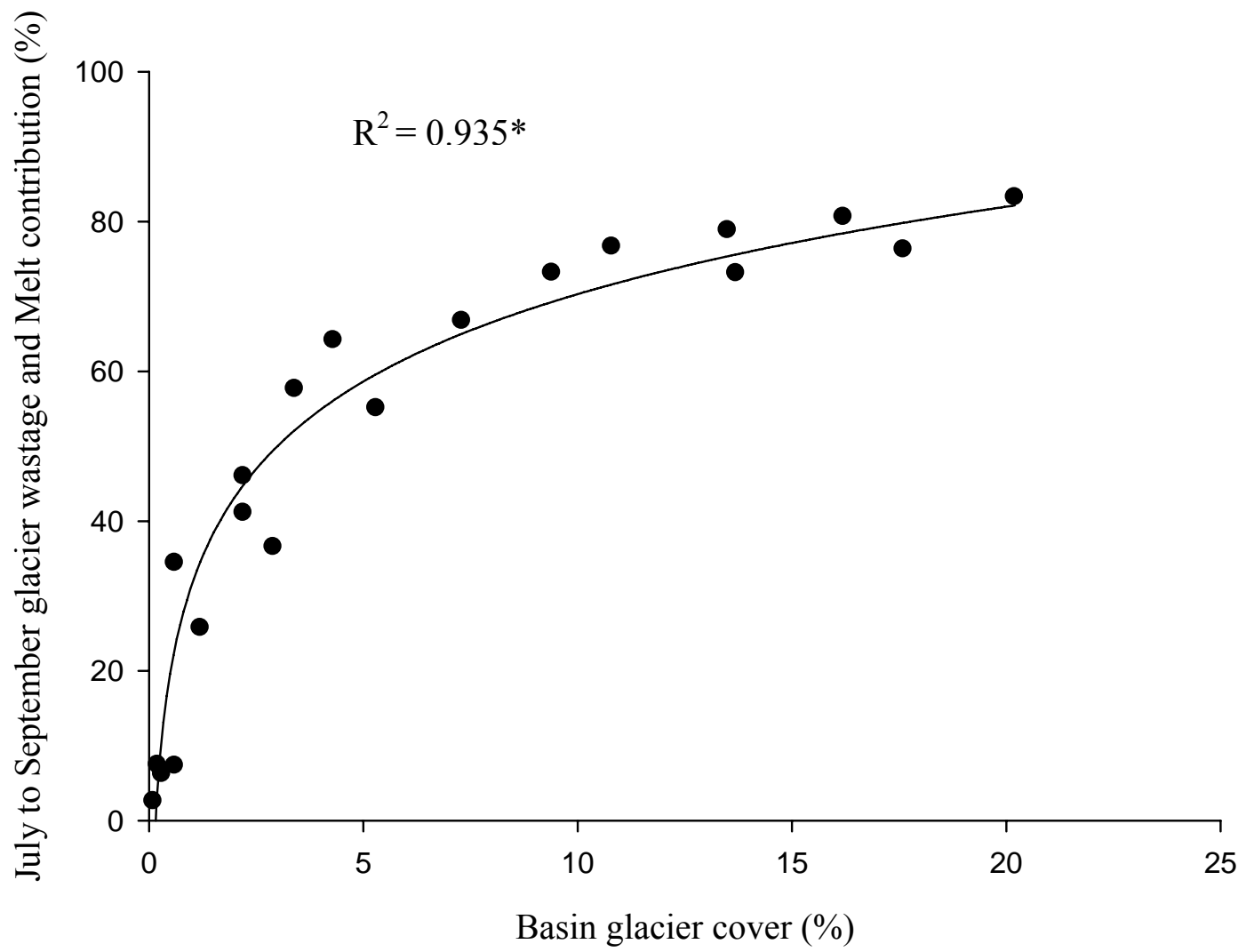

* significant at $\alpha=0.05$

Figure 5.5 Relationship between modelled percentage July to September combined glacier wastage and Melt contribution to streamflow and percentage basin glacier cover, with logarithmic trend line. Includes values from the time periods relating to the 1975 and 1998 glacier covers.

Figure 5.5 shows the strong correlation between basin glacier cover and percentage contribution of combined glacier wastage and Melt to late summer streamflow. The relationship shows a sharp decrease in glacier contribution when the glacier cover drops below 1-2\%. These modelled basins ranged from 110-2205 $\mathrm{km}^{2}$, and the strong positive correlation between combined glacier wastage and Melt contribution and basin glacier cover indicates, as expected, that percentage glacier cover has the greatest influence on glacier streamflow contribution, as opposed to basin size. The strong correlation of Figure 5.5 is as expected given the nature of the 
model and the representation of glaciers as a land cover percentage, and the conceptual simulation of glaciers within WATFLOOD (section 4.3.3) means that the simulation of glacier runoff is grossly simplified. There are, however, no observed glacier runoff data available to verify these results and relationship and to make any uncertainty estimates.

\subsection{Glacier Wastage and Melt from a Hydrological-hypsometric Comparison}

Glacierised and non-glacierised basins in the N and SSRB headwaters of similar size, hypsometry and with a common period of streamflow data were compared, and the difference between the July to September streamflow was calculated as an estimate of seasonal combined glacier wastage and Melt contribution (Table 5.5). For a number of basins it was not possible to calculate results for the 1993-2003 time period due to the lack of observed streamflow data for one or both of the basins compared. 
Table 5.5 Compared sub-basins of the N and SSRB with their glacier cover in 1975 and 1998, coefficient of variation and mean streamflow from July-September with corresponding percentage glacier contribution for 1970-1980 and 1993-2003 (where possible).

\begin{tabular}{|c|c|c|c|c|c|c|c|c|c|c|}
\hline \multirow[t]{2}{*}{ Size } & \multirow[t]{2}{*}{ Basin } & \multirow[t]{2}{*}{$\begin{array}{l}\text { Area } \\
\left(\mathrm{km}^{2}\right)\end{array}$} & \multicolumn{2}{|c|}{$\begin{array}{l}\text { Basin Glacier } \\
\text { Cover }(\%)\end{array}$} & \multicolumn{3}{|c|}{ 1970-1980 Time period } & \multicolumn{3}{|c|}{ 1993-2003 Time period } \\
\hline & & & 1975 & 1998 & $\begin{array}{l}\text { Jul-Sept } \\
\text { mean } \\
\text { stream- } \\
\text { flow } \\
(\mathrm{mm})\end{array}$ & $\begin{array}{l}\text { Glacier } \\
\text { contribu } \\
\text { tion } \\
(\%)\end{array}$ & $\begin{array}{l}C V \\
\text { of } \\
\text { stream- } \\
\text { flow }\end{array}$ & $\begin{array}{l}\text { Jul-Sept } \\
\text { mean } \\
\text { stream- } \\
\text { flow } \\
(\mathrm{mm})\end{array}$ & $\begin{array}{l}\text { Glacier } \\
\text { contrib } \\
\text { ution } \\
(\%)\end{array}$ & $\begin{array}{l}C V \\
\text { of } \\
\text { strea } \\
\text { m- } \\
\text { flow }\end{array}$ \\
\hline \multirow[b]{2}{*}{ 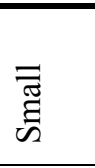 } & Peyto Glacier & 22.7 & 62.6 & 52.8 & 486.0 & 76.8 & 0.19 & - & - & - \\
\hline & $\begin{array}{l}\text { Silverhorn } \\
\text { Creek }\end{array}$ & 21.0 & 4.1 & 2.4 & 112.9 & - & 0.21 & - & - & - \\
\hline \multirow{10}{*}{ 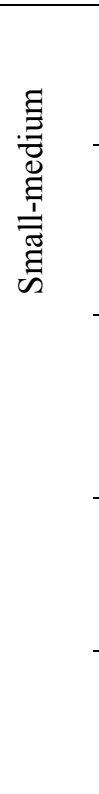 } & Baker Creek & $\begin{array}{l}125.8 \\
\end{array}$ & 1.2 & 0.5 & 90.0 & 51.2 & 0.45 & - & - & - \\
\hline & Johnson Creek & 122.9 & 0.6 & 0.2 & 43.9 & - & 0.43 & - & - & - \\
\hline & $\begin{array}{l}\text { Mistaya nr } \\
\text { Sask Crossing }\end{array}$ & 248.0 & 13.5 & 10.8 & 158.6 & 77.1 & 0.14 & 162.4 & 60.6 & 0.20 \\
\hline & Ghost River & 209.8 & 0.04 & 0.0 & 36.3 & - & 0.28 & 63.9 & - & 0.35 \\
\hline & $\begin{array}{l}\text { Bow R. below } \\
\text { Hector Lake }\end{array}$ & 279.4 & 10.6 & 8.6 & 174.7 & 91.7 & 0.25 & - & - & - \\
\hline & $\begin{array}{l}\text { North Ram } \\
\text { River }\end{array}$ & 347.3 & 0.0 & 0.0 & 14.6 & - & 0.54 & - & - & - \\
\hline & Pipestone & 306.7 & 4.3 & 2.2 & 93.8 & 79.8 & 0.41 & 85.7 & 67.3 & 0.26 \\
\hline & $\begin{array}{l}\text { North Ram } \\
\text { River }\end{array}$ & 347.3 & 0.0 & 0.0 & 19.0 & - & 0.50 & 28.0 & - & 0.64 \\
\hline & $\begin{array}{l}\text { Bow River } \\
\text { at Lake Louise }\end{array}$ & 422.4 & 9.4 & 7.3 & 127.5 & 62.2 & 0.21 & 127.2 & 55.1 & 0.15 \\
\hline & Cascade River & 452.1 & 0.6 & 0.1 & 48.2 & - & 0.24 & 57.2 & - & 0.24 \\
\hline \multirow{2}{*}{ 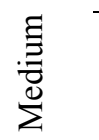 } & Siffleur River & 514.7 & 5.3 & 2.9 & 81.3 & 50.8 & 0.20 & - & - & - \\
\hline & Cardinal River & 493.4 & 0.0 & 0.0 & 40.0 & - & 0.46 & - & - & - \\
\hline \multirow{2}{*}{ 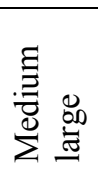 } & $\begin{array}{l}\text { North Sask at } \\
\text { Crossing }\end{array}$ & 1287.1 & 20.2 & 17.6 & 201.0 & 73.8 & 0.12 & - & - & - \\
\hline & $\begin{array}{l}\text { Clearwater } \\
\text { River }\end{array}$ & 1342.8 & 1.3 & 0.8 & 52.8 & - & 0.26 & - & - & - \\
\hline \multirow{2}{*}{ 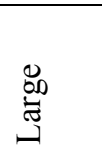 } & $\begin{array}{l}\text { North Sask. R } \\
\text { at Whirlpool }\end{array}$ & 1923.0 & 16.2 & 13.7 & 176.1 & 83.9 & 0.14 & 184.4 & 79.6 & 0.18 \\
\hline & Ram River & 1853.5 & 0.3 & 0.1 & 28.4 & - & 0.38 & 37.6 & - & 0.56 \\
\hline
\end{tabular}


Figure 5.6 below displays the evolution over the summer period of the differences in specific runoff between the compared basins as an average of the 1970-1980 time period (Table 5.5).

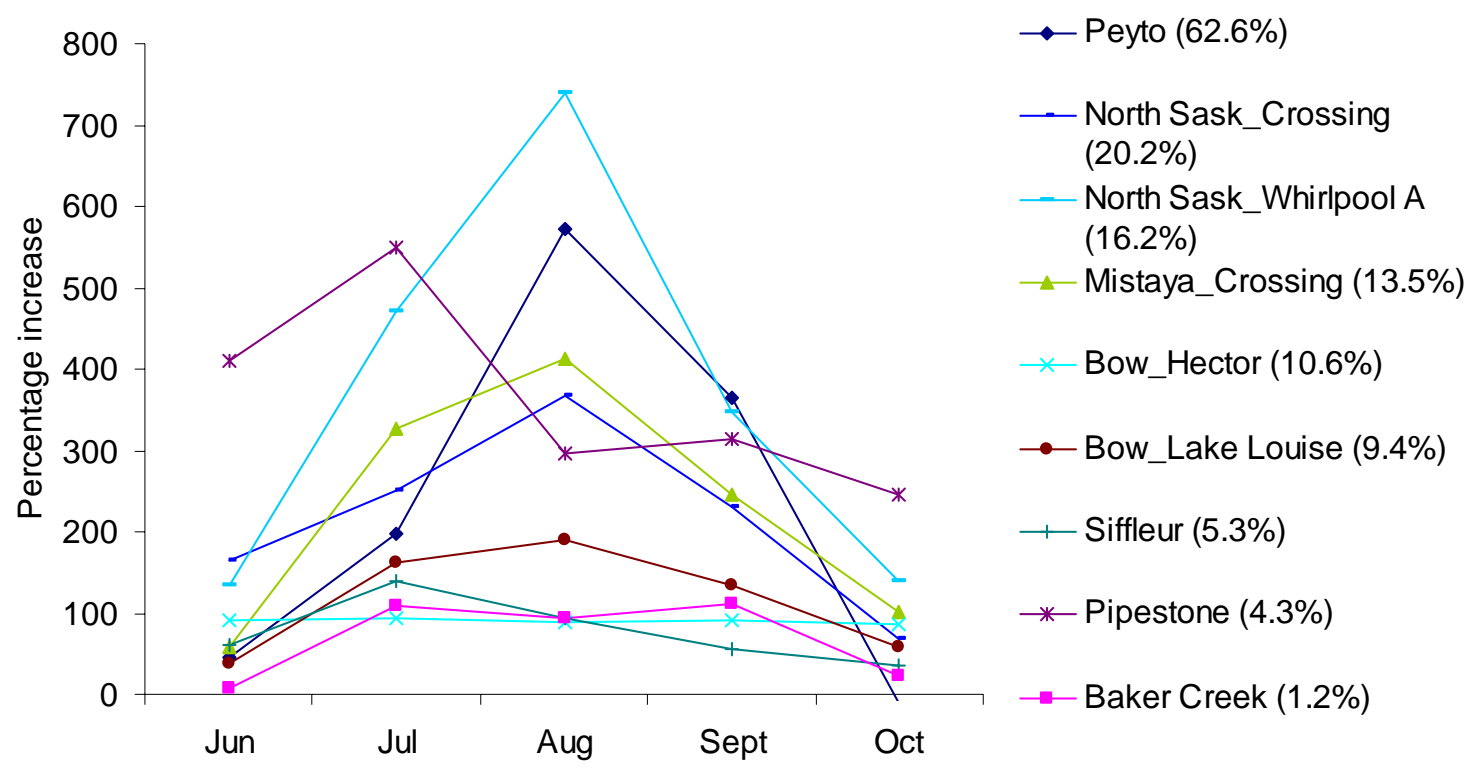

Figure 5.6 Percentage increase in the specific runoff for glacierised basins compared to similar non-glacierised basins. Between parenthesis is the percentage glacier cover (1975).

The basins with greater glacier cover $(>9 \%)$ have the greatest difference in streamflow relative to their non-glacierised basin in August, whereas basins with smaller glacier cover $(<6 \%)$ display less glacier impact and have the greatest runoff differences in July. It should be noted that this is referring to the month of the greatest difference in flow, not the month of the peak flow from the observed hydrograph. The exception to this is the Bow River below Hector Lake basin, which had very similar and abnormally low percentage increase of specific flow for the months of June to September. This may be due to the larger comparative area of the North Ram basin which is $68 \mathrm{~km}^{2}$ greater, or the result of limitations with the method (section 4.4.2). The difference in July to September streamflow between the basins compared was calculated as 
the seasonal combined glacier wastage and Melt contribution to flow. There are, however, many limitations with this method as described in section 4.4.2, and whilst the glacier contribution results are analysed here, caution is taken with regard to drawing conclusions since the difference in late summer streamflow between a glacierised and non-glacierised basin cannot be solely attributed to glacier runoff.

Based on the data in Table 5.5 for both the 1970-1980 and 1993-2003 time periods, the relationship between July to September combined glacier wastage and Melt contribution to streamflow and percentage basin glacier cover is displayed in Figure 5.7. 


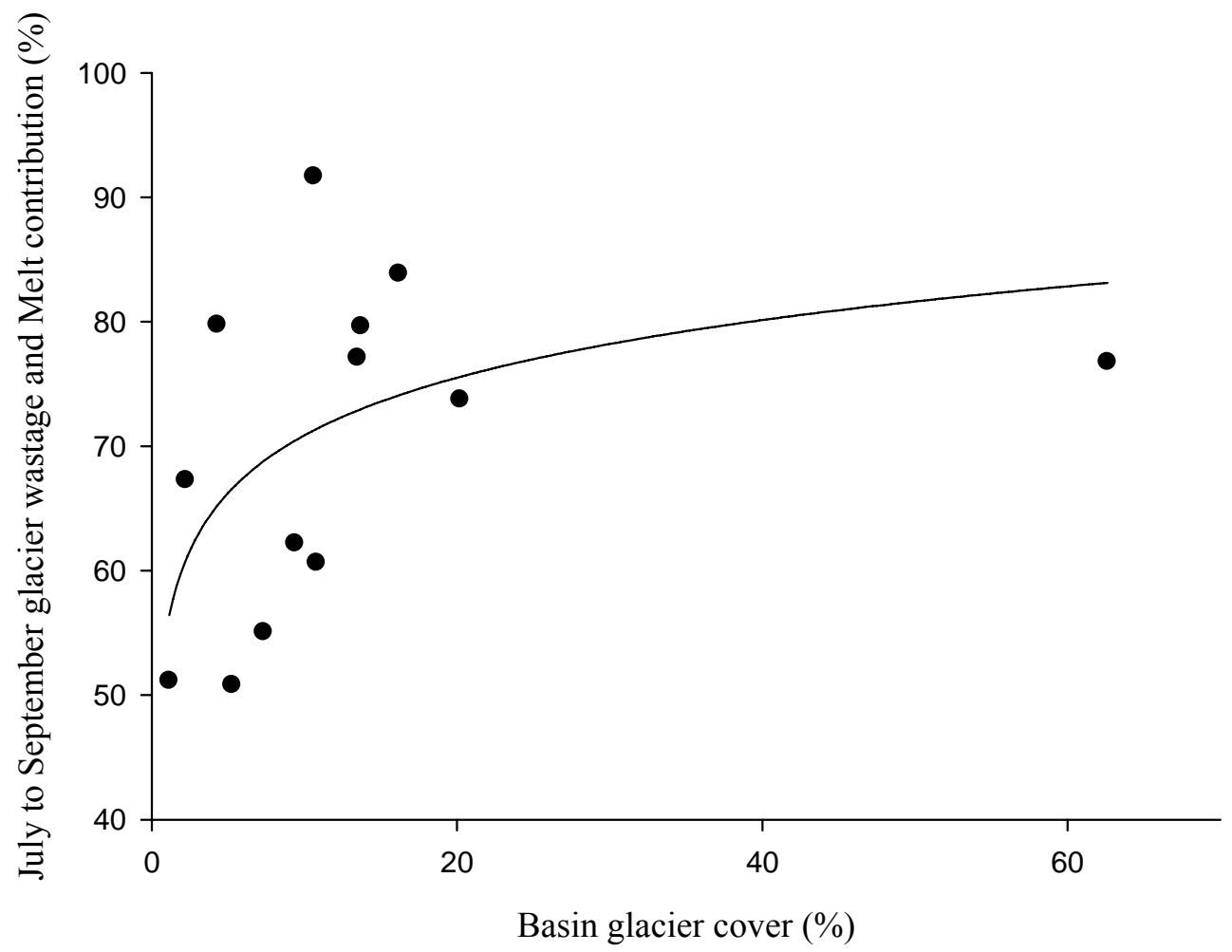

Figure 5.7 Relationship between percentage combined glacier wastage and Melt contribution to streamflow from the hydrological-hypsometric approach and percentage basin glacier cover

A log curve was fitted to Figure 5.7 for illustrative purposes due to the significant logarithmic relationship displayed in Figure 5.5 between the WATFLOOD modelled seasonal glacier wastage and Melt contribution to streamflow and basin glacier cover. The relationship between these same variables calculated from this alternative hydrological-hypsometric comparison (Figure 5.7) appears to follow a log trend but is reliant on one outlier, Peyto Glacier basin, with a very high basin glacier cover of 63\% (1975 cover). Significant figures are, therefore, not included for this spurious relationship and whilst there is an apparent increase in combined glacier wastage and Melt percentage contribution with basin glacier cover, definite conclusions are not drawn from this graph. The results are instead used to compare to the 
WATFLOOD model results on an annual basis due to the lack of alternative estimates of combined glacier wastage and Melt with which to compare to the model estimates. Observations of the differences in observed streamflow between the glacierised and non-glacierised basins compared using the hydrological-hypsometric approach are described and analysed as follows.

The following descriptive basin streamflow comparison is based on the data in Table 5.5. When the small basin (21.0 and $\left.22.7 \mathrm{~km}^{2}\right)$ flows were compared in the $1970-1980$ period, it was observed that the greater glacierised basin, Peyto Glacier, had a peak flow in August and higher specific runoff reflecting the high percentage glacier cover (62.6\%) relative to Silverhorn (4.1\%) with peak flow in July. By comparing the July to September flow means, the estimated combined glacier wastage and Melt contribution to July to September flow in Peyto Glacier basin was $77 \%$. Peyto Glacier basin also had a slightly lower $C V(0.19)$ than Silverhorn (0.21), though this difference is not large enough to be considered evidence of the natural regulatory influence of glaciers on streamflow. Unfortunately this comparison could not be made for the later 1993-2003 time period due to lack of available flow data.

Comparison between the small-medium basins (122.9 to $\left.248.0 \mathrm{~km}^{2}\right)$ revealed a greater specific July to September flow in the glacierised basins than the non-glacierised basins. In the 1970-1980 period, Baker Creek had little glacier coverage (1.2\%) hence the peak flow was in July rather than August, and the $C V$ was similar to its comparative basin Johnson ( $0.6 \%$ glacier cover) with $C V \mathrm{~s}$ of 0.45 and 0.43 , respectively, likely due to the small difference in glacier cover between basins. The specific flow for Baker Creek, however, was much larger than that for Johnson basin with percentage glacier contribution in the July to September period calculated as $51 \%$. Mistaya River basin flow had a lower $C V(0.14)$ than the other less glacierised and non- 
glacierised basins in the 1970-1980 period, likely due to its higher glacier cover (14\%). Mistaya River had a greater specific flow than Ghost River with glacier contribution in the 1970-1980 period calculated as $77 \%$ from July to September. Mistaya River and Ghost River could also be compared for the 1993-2003 period, and similarly the specific streamflow was greater for the Mistaya River basin, with July to September glacier contribution calculated as $61 \%$. In addition, the $C V$ was smaller for the Mistaya River streamflow ( 0.28 compared to 0.35 for Ghost River) in the 1993-2003 period with peak flows in July and August as opposed to June and July for Ghost River.

For the medium basin comparisons (279.4 to $514.7 \mathrm{~km}^{2}$ ), all glacierised basins had greater specific July to September flow than their similar non-glacierised basin, despite in most cases the non-glacierised basin being larger in size. Glacier contribution to flow in each basin was high in the 1970-1980 period, ranging from 51\% at Siffleur with one of the smallest glacier covers $(5.3 \%)$ and the largest basin size $\left(514.7 \mathrm{~km}^{2}\right)$, to $92 \%$ at Bow below Hector Lake with the greatest glacier cover $(10.6 \%)$ and the smallest basin size $\left(279.4 \mathrm{~km}^{2}\right)$. In every case the July to September $C V$ was smaller for the glacierised basin, and similar results were seen for those basins that could be compared for the 1993-2003 period. In this later period high glacier contributions were estimated of $67 \%$ for Pipestone ( $2.2 \%$ glacier cover) and $55 \%$ for the larger size Bow at Lake Louise basin (7.3\% glacier cover), and lower $C V$ values were calculated for these glacierised basins relative to the non-glacierised basins.

For the medium-large basins (1287.1 to $\left.1342.8 \mathrm{~km}^{2}\right)$, the North Saskatchewan River at Saskatchewan Crossing and Clearwater River were compared over an earlier time period (1959 to 1969) due to the lack of other available flow data. The North Saskatchewan River at Saskatchewan Crossing $\left(1287.1 \mathrm{~km}^{2}\right)$ with a glacier cover of $20 \%$ had a lower $C V$, later peak 
flow in July and August and a large glacier contribution of 74\%, despite Clearwater River basin being much larger in size of $1342.8 \mathrm{~km}^{2}$. Similarly, for the larger basin comparison (1853.5 to $\left.1923.0 \mathrm{~km}^{2}\right)$ the North Saskatchewan River at Whirlpool (16.2\% glacier cover) had a lower CV of 0.14 than the Ram River ( $0.3 \%$ glacierised) with a $C V$ of 0.38 in the $1970-1980$ period, with similar results in the 1993-2003 period. Glacier contribution for July to September in the North Saskatchewan at Whirlpool basin is estimated at $84 \%$ in the $1970-1980$ time period, dropping to $80 \%$ in the 1993-2003 period, with peak flows in July and August in contrast to the Ram River basin with peak flows in May.

In summary, the natural regulating influence of glaciers resulted in the observation of generally lower streamflow coefficients of variation in glacierised basins relative to nonglacierised basins. Glacierised basins also had increased specific runoff in the July to September period, despite in some cases having a smaller contributing area, with delayed peak flows in these late summer months. This increased specific runoff can be partially attributed to the combined glacier wastage and Melt contribution to streamflow in glacierised basins in July to September. Other differences between the basins compared, however, could also have resulted in the observed differences in streamflow such as differing land cover, elevation, groundwater systems, and climate regimes, and it is possible that there is inter-flow between some of these basins. Differences in streamflow between the glacierised and non-glacierised basins can therefore not be solely attributed to glacier wastage and Melt contribution. These results are therefore used as a best estimate of combined glacier wastage and Melt with which to compare to the WATFLOOD results in the absence of data on glacier runoff in the N and SSRB. 


\subsection{Glacier Wastage from Ice Volume Estimation and Change}

The glacier volumes and net volume loss from 1975-1998 were calculated from a

volume-area scaling law. These are shown in Table 5.6, in which the areas refer to those

displayed in Figures 3.2 and 3.3.

Table 5.6 Total glacier ice volume and ice volume change from 1975-1998 in the headwaters of the $\mathrm{N}$ and SSRB.

\begin{tabular}{|c|c|c|c|c|}
\hline Area & $\begin{array}{l}\text { Volume } \\
1975 \\
\left(\times 10{ }^{6} \mathrm{~m}^{3}\right)\end{array}$ & $\begin{array}{l}\text { Volume } \\
1998 \\
\left(x 10^{6} \mathrm{~m}^{3}\right)\end{array}$ & $\begin{array}{l}\text { Change in } \\
\text { Volume 1975-1998 } \\
\left(\times 10^{6} \mathrm{~m}^{3}\right)\end{array}$ & $\begin{array}{l}\text { Estimated \% } \\
\text { volume loss } \\
\text { 1975-1998 }\end{array}$ \\
\hline \multicolumn{5}{|c|}{ North Saskatchewan River Basin (not including Brazeau) } \\
\hline Upper North Sask & 21251 & 18789 & -2462 & 11.6 \\
\hline Cline River & 743 & 343 & -400 & 53.8 \\
\hline Siffleur River & 792 & 412 & -381 & 48.1 \\
\hline Mistaya River & 747 & 547 & -200 & 26.8 \\
\hline Clearwater River & 523 & 313 & -210 & 40.2 \\
\hline Peyto Creek & 996 & 806 & -190 & 19.1 \\
\hline Central North Sask & 441 & 210 & -231 & 52.4 \\
\hline Ram River & 119 & 42 & -77 & 64.7 \\
\hline Lower Mistaya & 124 & 95 & -29 & 23.4 \\
\hline White Rabbit Creek & 97 & 0.39 & -97 & 100.0 \\
\hline Lower North Sask & 21 & 6.5 & -14 & 66.7 \\
\hline Silverhorn Creek & 15 & 7.9 & -7.6 & 50.7 \\
\hline Total km $\mathbf{k m}^{3}$ & 25.87 & 21.57 & -4.30 & 16.6 \\
\hline \multicolumn{5}{|c|}{ South Saskatchewan River Basin (not including Oldman) } \\
\hline Bow River & 2222 & 1649 & -573 & 25.8 \\
\hline Bow at Lake Louise & 1826 & 1471 & -356 & 19.5 \\
\hline Red Deer River & 1418 & 791 & -628 & 44.3 \\
\hline Kananaskis River & 703 & 391 & -312 & 44.4 \\
\hline Pipestone River & 417 & 213 & -204 & 48.9 \\
\hline Spray River & 232 & 127 & -105 & 45.3 \\
\hline Redearth Creek & 91 & 55 & -36 & 39.6 \\
\hline \multicolumn{5}{|l|}{ Cascade River Lake } \\
\hline Minnewanka & 38 & 9.3 & -29 & 76.3 \\
\hline Highwood River & 34 & 0.53 & -33 & 97.1 \\
\hline Baker Creek & 26 & 8.7 & -17 & 65.4 \\
\hline Brewster Creek & 18 & 4.5 & -13 & 72.2 \\
\hline Johnston Creek & 13 & 4.3 & -8.7 & 66.9 \\
\hline Elbow River & 4.3 & 1.6 & -2.7 & 62.8 \\
\hline Ghost River & 0.84 & 0 & -0.84 & 100.0 \\
\hline Total $\mathbf{k m}^{3}$ & 5.22 & 3.25 & -1.96 & 37.5 \\
\hline
\end{tabular}


The net volume change from 1975-1998 (in water equivalent $=$ ice volume divided by 0.9167) for each area was found as a percentage of observed streamflow at the corresponding flow gauge (Table 5.7). The ice volume change in Table 5.7 is given as the annual average water equivalent (w.e.) from 1975-1998, and the area refers to that displayed in Figures 3.2 and 3.3. To indicate where the average glacier wastage per year was found as a percentage of the average flow from a shorter time period, the years of flow data are given and it is stated when there was no available streamflow data. It should be noted that the average annual wastage in Table 5.7 refers to the total cumulative net wastage from all upstream sub-basins, and the percentage glacier cover of the upstream area is an average of the 1975 and 1998 extents. 
Table 5.7 Glacier volume change (net wastage) as a percentage of observed streamflow, annually and in the July to September period.

\begin{tabular}{|c|c|c|c|c|c|c|}
\hline \multirow[t]{2}{*}{ Area } & \multirow[t]{2}{*}{$\begin{array}{l}\text { Gauge ID } \\
\text { No. }\end{array}$} & \multirow[t]{2}{*}{$\begin{array}{l}\text { Glacier } \\
\text { Cover } \\
(\%)\end{array}$} & \multirow[t]{2}{*}{$\begin{array}{l}\text { Flow Data } \\
\text { Time } \\
\text { Period }\end{array}$} & \multirow{2}{*}{$\begin{array}{l}\text { Average } \\
\text { Annual } \\
\text { Wastage (km³ } \\
\text { water } \\
\text { equivalent) }\end{array}$} & \multicolumn{2}{|c|}{$\begin{array}{l}\text { Percentage } \\
\text { contribution to } \\
\text { streamflow }\end{array}$} \\
\hline & & & & & July-Sept & Annual \\
\hline \multicolumn{7}{|l|}{$\begin{array}{l}\text { North Saskatchewan } \\
\text { River Basin (not } \\
\text { including Brazeau) }\end{array}$} \\
\hline Upper North Sask & 05DA006 & 18.9 & No data & 98 & No Data & No Data \\
\hline Cline River & 05DA004 & 2.7 & No Data & 16 & No Data & No Data \\
\hline Siffleur River & 05DA002 & 4.1 & 1975-1996 & 15 & 10.9 & No Data \\
\hline Mistaya River & 05DA007 & 12.1 & 1975-1998 & 16 & 13.2 & 7.8 \\
\hline Clearwater River & $05 \mathrm{DB} 003$ & 1.0 & 1975-1992 & 8.4 & 4.5 & No Data \\
\hline Peyto Creek & 05DA008 & 57.7 & 1967-1977 & 7.6 & 21.7 & No Data \\
\hline Central North Sask & 05DA009 & 15.0 & 1975-1998 & 124 & 12.0 & 7.3 \\
\hline Ram River & 05DC008 & 0.2 & 1975-1998 & 3.0 & 1.6 & 0.6 \\
\hline Lower Mistaya & 05DA005 & 10.8 & No Data & 17 & No Data & No Data \\
\hline White Rabbit Creek & 05DA001 & 1.7 & No Data & 3.9 & No Data & No Data \\
\hline Lower North Sask & 05DA003 & 12.1 & No Data & 140 & No Data & No Data \\
\hline Silverhorn Creek & 05DA010 & 3.3 & 1975-1998 & 0.3 & 4.2 & 2.2 \\
\hline \multicolumn{7}{|l|}{$\begin{array}{l}\text { South Saskatchewan } \\
\text { River Basin (not } \\
\text { including Oldman) }\end{array}$} \\
\hline Bow River & 05BB001 & 2.8 & $1975-1998$ & 26 & 4.8 & 2.2 \\
\hline Bow Lake Louise & 05BA001 & 8.4 & 1975-1998 & 14 & 8.7 & 4.5 \\
\hline Red Deer River & 05CA009 & 1.1 & 1975-1998 & 25 & 8.6 & 3.7 \\
\hline Kananaskis River & $05 \mathrm{BF} 023$ & 2.4 & No data & 12 & No Data & No Data \\
\hline Pipestone River & 05BA002 & 3.3 & $1975-1998$ & 8.1 & 10.5 & 4.3 \\
\hline Spray River & 05BC001 & 1.0 & 1975-1998 & 4.2 & Regulated & 4.4 \\
\hline Redearth Creek & $05 \mathrm{BB} 005$ & 2.3 & 1975-1996 & 1.4 & 3.3 & No Data \\
\hline $\begin{array}{l}\text { Cascade R. Lake } \\
\text { Minnewanka }\end{array}$ & 05BD005 & 0.3 & 1975-1996 & 1.1 & 1.7 & No Data \\
\hline Highwood River & 05BL019 & 0.1 & 1975-1998 & 1.1 & 1.4 & No Data \\
\hline Baker Creek & 05BA007 & 0.8 & 1973-1976 & 0.67 & 2.0 & No Data \\
\hline Brewster Creek & 05BB004 & 0.7 & $1975-1996$ & 0.54 & 3.7 & No Data \\
\hline Johnston Creek & 05BA006 & 0.4 & 1975-1996 & 3.4 & 1.4 & No Data \\
\hline Elbow River & 05BJ006 & 0.1 & $1975-1995$ & 0.11 & 0.2 & 0.1 \\
\hline Ghost River & 05BG002 & 0.02 & $1975-1993$ & 0.033 & 0.1 & No Data \\
\hline
\end{tabular}

The percentage glacier wastage contribution in the South Saskatchewan River basin

headwaters ranges from below 1 to $4.5 \%$ annually, increasing in range to below 1 to $10.5 \%$ in the 
July to September period for basins with glacier cover ranging from 0.02 to $8.4 \%$. For the North Saskatchewan River basin headwaters, glacier wastage contribution ranges from below 1 to $7.8 \%$ annually, increasing to 1.6 to $21.7 \%$ in the July to September period for glacierised basins with glacier cover ranging between 0.2 to $58 \%$ (Table 5.7). Figure 5.8 displays the relationship between percentage glacier cover and percentage glacier wastage contribution, annually and in the July to September period, for each basin studied in the N and SSRB using mean values of the 1975 and 1998 basin glacier cover.

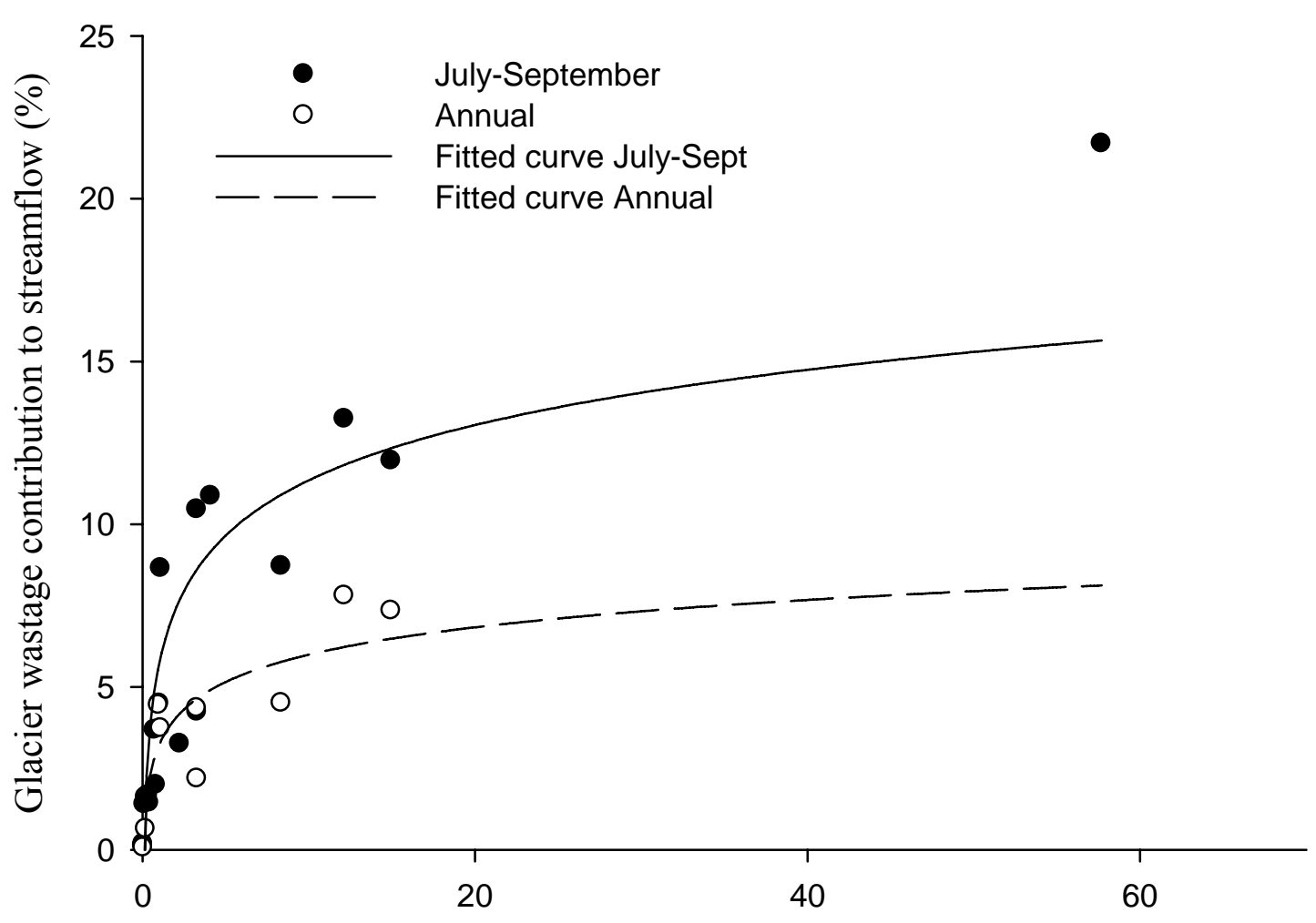

Basin glacier cover $(\%)$

Figure 5.8 Relationship between percentage glacier wastage contribution to streamflow and percentage basin glacier cover, annually and in the July to September period from 1975-1998 
Figure 5.8 shows that in general, the greater the percentage basin glacier cover, the greater the percentage wastage contribution to flow. A logarithmic curve was fitted to the graph for illustrative purposes since the data appear to follow this trend, the curve, however, was extrapolated beyond the data for the annual contribution to flow, and towards only one outlier for the July to September contribution to flow, therefore significance figures are not included for this spurious relationship. Glacier wastage contribution varied between basins and not necessarily according to basin glacier cover, though did contribute over $10 \%$ of streamflow in the July to September period in six basins, including those with glacier cover as little as $3.3 \%$. Individual glacier response to regional climate change likely explains the observed differences in percentage glacier volume loss from each basin from 1975-1998 within both the N and SSRB headwaters (Table 5.6). Similarly, individual glacier response may explain differences in wastage percentage contribution for basins with similar percentage glacier cover such as the Bow River at Banff (2.8\% glacierised) and Pipestone River (3.3\% glacierised) basins, for which wastage contributed $4.8 \%$ and $10.5 \%$ respectively in July to September (Table 5.7). Bow River at Banff basin experienced a 26\% loss of glacier volume and Pipestone a 49\% loss between 19751998. Basins with similar glacier cover experiencing similar percentage volume loss, however, also showed differences in wastage contribution percentages, such as Silverhorn $(3.3 \%$ glacierised, 48\% glacier volume loss) and Siffleur (4.1\% glacierised, 51\% glacier volume loss) basins for which wastage contributed $4.2 \%$ and $10.9 \%$ of July to September streamflow, respectively. This indicates that there are other factors influencing percentage wastage contribution, such as differences in late summer streamflow relative to the proportion of glacier wastage runoff as a result of differing local precipitation regimes and land covers. In addition, the total volume of glacier wastage runoff may not reach the glacier basin streamflow in every 
basin if there is groundwater or inter-basin flow exchange, or interception by varying basin landcovers, which may also explain differences in percentage wastage contribution.

\subsection{Comparison of Glacier Wastage and Melt results}

\subsubsection{Comparison of WATFLOOD and hydrological-hypsometric approaches}

Both the WATFLOOD results and those from the hydrological-hypsometric approach calculated combined glacier wastage and Melt, and thus could be compared for the common basins. Table 5.8 shows the average percentage combined glacier wastage and Melt contribution to July to September streamflow for both the WATFLOOD and hydrological-hypsometric comparison methods for the entire common time period, and percentage difference in average results.

Table 5.8 Glacierised basins and their estimated July to September combined glacier wastage and Melt contribution by WATFLOOD (WAT) and the hydrological-hypsometric $(\mathrm{H}-\mathrm{H})$ basin comparison.

\begin{tabular}{lllll}
\hline Glacierised basin & \multicolumn{2}{l}{$\begin{array}{l}\text { Average glacier } \\
\text { contribution } \\
\text { July-Sept (\%) }\end{array}$} & \multirow{2}{*}{$\begin{array}{l}\text { Difference } \\
\mathbf{( \% )}\end{array}$} & $\begin{array}{l}\text { Common } \\
\text { Time- } \\
\text { period }\end{array}$ \\
\cline { 2 - 3 } & WAT & H-H & & \\
\hline Mistaya at Saskatchewan & 78 & 76 & 3 & $1973-1983$ \\
Crossing & 69 & 58 & 15 & $1990-1993$ \\
Pipestone & 62 & 77 & -25 & $1975-1977$ \\
& 45 & 67 & -49 & $1993-2003$ \\
Bow at Lake Louise & 73 & 62 & 15 & $1973-1980$ \\
& 62 & 55 & 12 & $1990-1996$ \\
Siffleur & 55 & 55 & -1 & $1975-1983$ \\
North Saskatchewan at & 80 & 85 & -6 & $1973-1983$ \\
Whirlpool & 71 & 82 & -15 & $1993-2003$ \\
& & & & \\
\hline
\end{tabular}


Both the WATFLOOD model and the hydrological-hypsometric approaches were used to estimate seasonal glacier wastage and Melt contribution to flow in the July to September period. There does not appear to be a systematic over- or underestimation of glacier contribution between the WATFLOOD and hydrological-hypsometric methods (Table 5.8). Figure 5.9 below displays this comparison in graphic form, plotting the combined glacier wastage and Melt contribution for each year of the common time periods. The glacier contribution from the two methods in the Pipestone River basin shows a high percentage difference of $25 \%$ and $49 \%$ for the time periods relating to the 1975 and 1998 glacier covers, respectively, with the hydrologicalhypsometric approach calculating the higher glacier contribution value. The other basins have a lower than $15 \%$ difference in glacier wastage and Melt estimation from the two methods, with the average difference being $10 \%$ (Table 5.8).

WATFLOOD is a more consistent approach than the hydrological-hypsometric comparison, the latter method of which has many limitations but is used to compare to the WATFLOOD results. The data were originally plotted on one graph, which was then split into two due to the lack of mid-range data. It appears there is a significant, though not strong, correlation between the WATFLOOD and hydrological-hypsometric approach results, which is encouraging with regard to using WATFLOOD to model regional glacier combined wastage and Melt contribution. There are no measurements of combined glacier wastage and Melt runoff for the N and SSRB headwater region with which to verify the results calculated by WATFLOOD and the hydrological-hypsometric approach. 

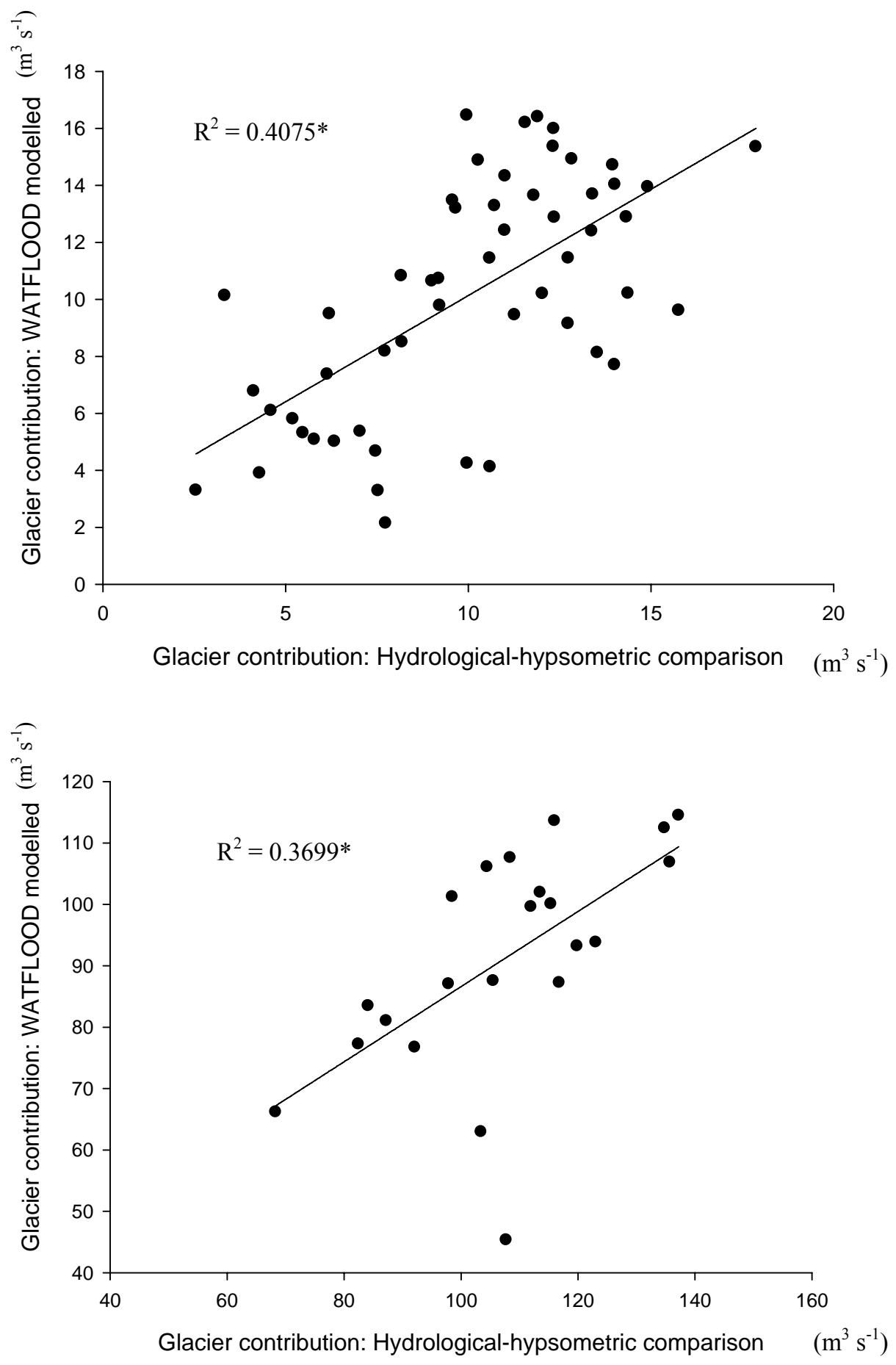

$*_{\text {significant at } \alpha=0.05}$

Figure 5.9 Relationship between combined glacier wastage and Melt contribution from July to September modelled by WATFLOOD and estimated from the hydrological-hypsometric comparison approach 


\subsubsection{Calculation of Melt}

The combined glacier wastage and Melt results estimated by WATFLOOD (WAT) and the glacier wastage results from the volume-area relationship approach could also be compared, with the difference calculated as a percentage of the WATFLOOD simulated streamflow (with glaciers) as an estimation of average seasonal Melt contribution from 1975-1998 (Table 5.9).

Table 5.9 Difference between combined glacier wastage and Melt (WATFLOOD) and glacier wastage (volume-area) as an estimation of Melt percentage seasonal contribution to streamflow from $1975-1998$ in $\times 10^{6} \mathrm{~m}^{3}$.

\begin{tabular}{|c|c|c|c|c|c|}
\hline \multirow[t]{2}{*}{ Glacierised basin } & \multicolumn{2}{|c|}{ 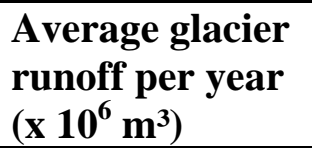 } & \multirow[t]{2}{*}{$\begin{array}{l}\text { Melt } \\
\left(\mathbf{x ~ 1 0} \mathrm{m}^{3}\right)\end{array}$} & \multirow{2}{*}{$\begin{array}{l}\text { Melt } \\
\text { contribution to } \\
\text { streamflow } \\
\text { Jul -Sept (\%) }\end{array}$} & \multirow{2}{*}{$\begin{array}{l}\text { Basin glacier } \\
\text { cover } \\
\text { (average } \\
1975 \text { and 1998) }\end{array}$} \\
\hline & WAT & $\begin{array}{l}\text { Volume } \\
\text { - Area } \\
\end{array}$ & & & \\
\hline \multicolumn{6}{|l|}{$\begin{array}{l}\text { North Saskatchewan } \\
\text { River Basin }\end{array}$} \\
\hline $\begin{array}{l}\text { North Saskatchewan at } \\
\text { Sask Crossing }\end{array}$ & 518.7 & 98.1 & 420.6 & 64.0 & 18.9 \\
\hline $\begin{array}{l}\text { North Saskatchewan at } \\
\text { Whirlpool }\end{array}$ & 617.5 & 124.3 & 493.2 & 60.3 & 15.0 \\
\hline Mistaya at Crossing & 87.2 & 15.8 & 71.4 & 62.7 & 12.1 \\
\hline Siffleur near mouth & 44.5 & 15.2 & 29.3 & 27.3 & 4.1 \\
\hline \multicolumn{6}{|l|}{ South Saskatchewan } \\
\hline Bow at Lake Louise & 98.7 & 14.2 & 84.5 & 59 & 8.4 \\
\hline Pipestone & 40.3 & 8.1 & 32.1 & 42.5 & 3.3 \\
\hline Bow at Banff & 169.7 & 25.8 & 143.8 & 38.8 & 2.8 \\
\hline Brewster & 1.0 & 0.5 & 0.4 & 4.0 & 0.7 \\
\hline Johnston & 2.8 & 0.3 & 2.5 & 15.4 & 0.4 \\
\hline $\begin{array}{l}\text { Cascade at Lake } \\
\text { Minnewanka }\end{array}$ & 1.7 & 1.1 & 0.5 & 1.1 & 0.3 \\
\hline
\end{tabular}

With reference to Table 5.9, Melt contributed considerable volumes of water to the July to September streamflow of glacierised basins from 1975-1998, contributing over 60\% of streamflow from basins with glacier cover greater than $10 \%$. Furthermore, Melt also contributed 
considerably to July to September streamflow from basins with a smaller percentage glacier cover (2-8\%) with Melt contributions ranging from 27-59\%. Generally, Melt contributed less than $10 \%$ to the July to September streamflow from basins with less than $1 \%$ glacier cover, with the exception of Johnston Creek with a July to September contribution of $15 \%$. Melt is not calculated as a percentage of annual flow since glacier contribution to streamflow in terms of Melt is only significant on a seasonal time scale. The relationship between percentage basin glacier cover (as an average of 1975 and 1998 cover) and average percentage Melt contribution to flow in the July to September period from 1975-1998 based on the data in Table 5.9 is shown in Figure 5.10.

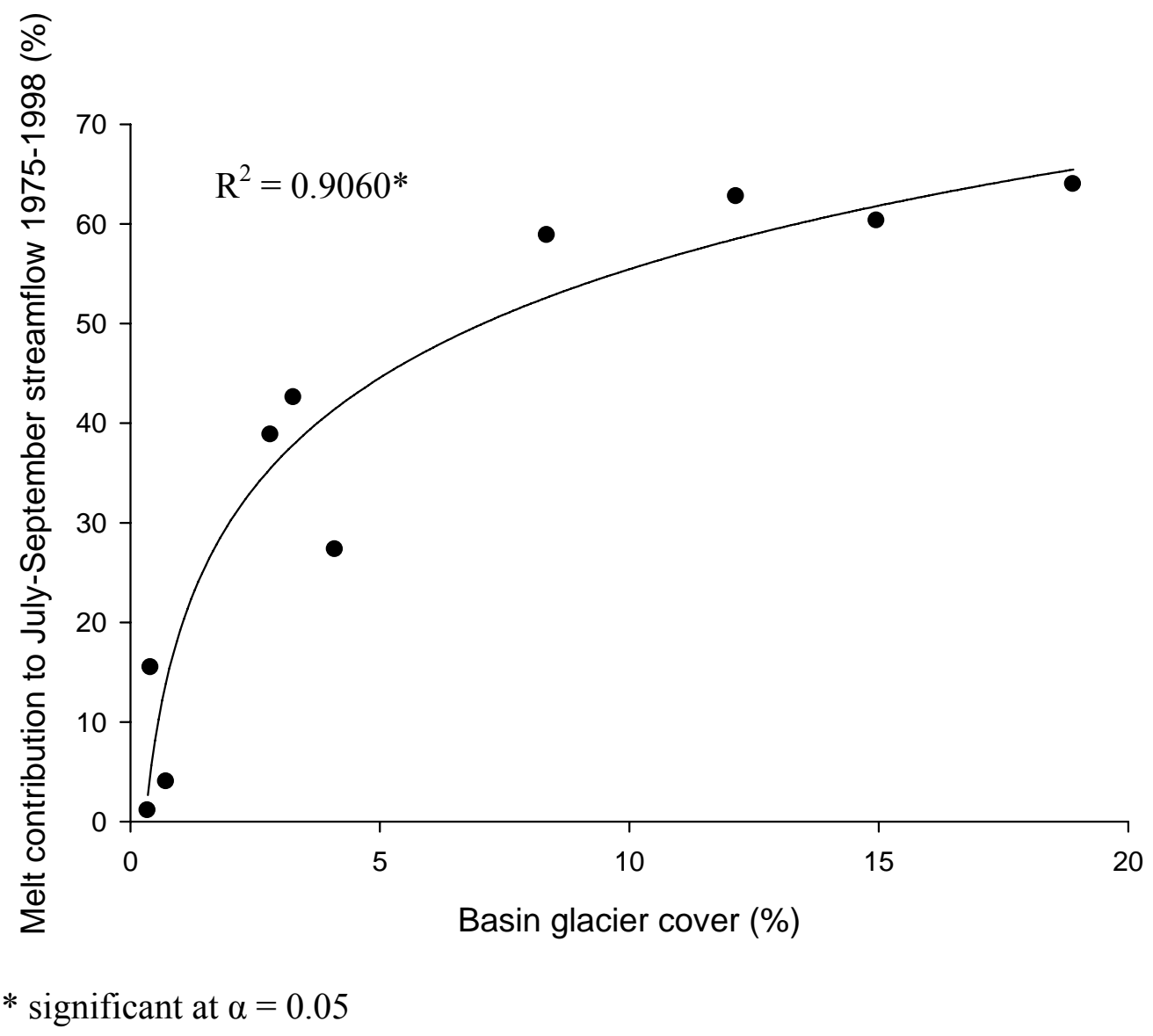

Figure 5.10 Relationship between percentage basin glacier cover and average percentage Melt contribution to July to September streamflow 1975-1998. Basin glacier cover is the average of the 1975 and 1998 glacier cover. 
Melt percentage contribution is strongly correlated with basin glacier cover. Whilst this may be a reflection of the representation of glaciers within WATFLOOD (section 4.2.1.3), this relationship is also expected since the greater the glacier accumulation area and area of exposed ice in the summer, the larger the volume of Melt runoff. Therefore as glaciers decline the volume of Melt runoff will decrease as annual snow accumulation on the glacier decreases, affecting the seasonal streamflow with decreased summer flows and an advance of the peak flow towards a non-glacial snowmelt regime hydrograph (assuming post-glacial conditions do not similarly delay snowmelt runoff).

\subsection{Glacier Wastage and Melt in Peyto Glacier Basin}

Peyto Glacier basin observed streamflow at gauge 05DA007 is presented in Table 5.10 below, from which percentage glacier contribution is calculated.

Table 5.10 Peyto Glacier basin (05DA007) observed streamflow x $10^{6} \mathrm{~m}^{3}$. Source data: HYDAT (Environment Canada WSC: HYDAT)

\begin{tabular}{llllllll}
\hline Year & May & June & July & Aug & Sept & Oct & $\begin{array}{l}\text { July-Sept } \\
\text { sum }\end{array}$ \\
\hline 1967 & 0 & 3.1 & 11 & 17 & 9.7 & 0 & 39 \\
1968 & 0 & 5.5 & 14 & 12 & 4.8 & 1.2 & 30 \\
1969 & 2.1 & 10 & 11 & 14 & 4.4 & 0 & 29 \\
1970 & 0.72 & 12 & 18 & 19 & 196 & 0 & 55 \\
1971 & 3.2 & 5.2 & 14 & 23 & 2.9 & 0 & 41 \\
1972 & 0.42 & 9.2 & 13 & 16 & 3.3 & 0.52 & 33 \\
1973 & 0 & 5.3 & 13 & 12 & 6.2 & 0 & 31 \\
1974 & 0 & 9.3 & 15 & 16 & 8.8 & 0 & 40 \\
1975 & 0 & 3.0 & 16 & 6.7 & 2.0 & 0 & 25 \\
1976 & 1.8 & 2.8 & 9.4 & 14 & 12 & 0 & 35 \\
1977 & 0 & 6.5 & 10 & 15 & 1.7 & 0 & 26 \\
\hline
\end{tabular}




\subsubsection{WATFLOOD results}

The observed and simulated (using the 1975 glacier cover) hydrographs for Peyto Glacier basin are shown in Figure 5.11 below. There are differences in the WATFLOOD simulated and observed streamflow hydrographs as expected due to the conceptual modelling of glaciers within WATFLOOD (section 4.2.1.3) of this highly glacierised, relatively small basin. Nevertheless, the results were compared to those from the other methods as an indication of how well combined glacier wastage and Melt was modelled in this basin.

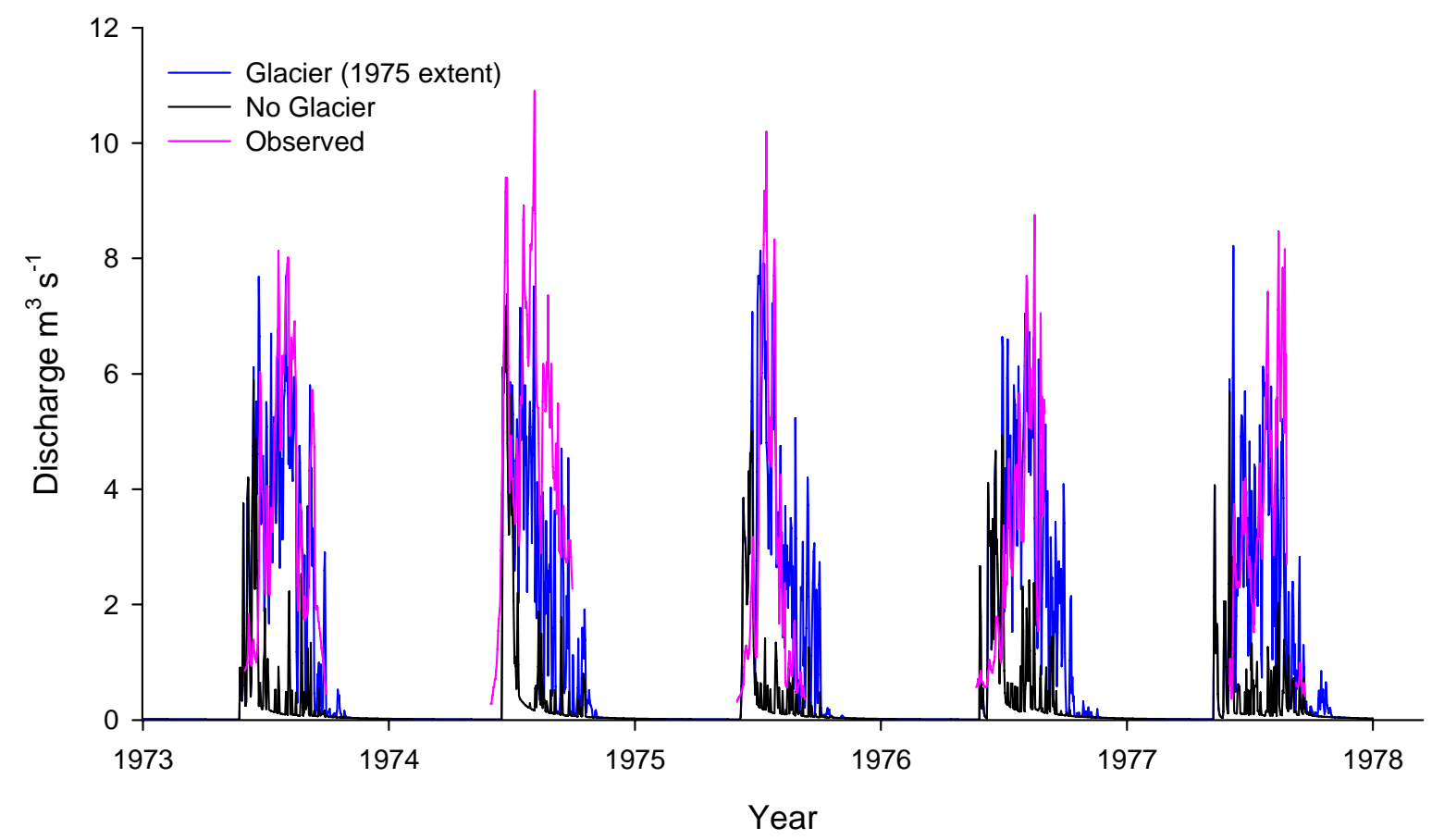

Figure 5.11 Peyto Glacier basin WATFLOOD simulated (with and without glaciers) and observed streamflow from 1973-1978

The WATFLOOD modelled combined glacier wastage and Melt contribution to streamflow from Peyto Glacier basin are presented in Table 5.11. The average combined glacier 
wastage and Melt runoff from July to September was $21 \times 10^{6} \mathrm{~m}^{3}$ for $1973-1977$, which was $87 \%$ of the average simulated flow with glaciers from July to September $\left(24 \times 10^{6} \mathrm{~m}^{3}\right)$.

Table 5.11 Monthly combined glacier wastage and Melt runoff from Peyto Glacier basin $\times 10^{6} \mathrm{~m}^{3}$ from 1973-1977 modelled by WATFLOOD

\begin{tabular}{lllll}
\hline Year & \multicolumn{4}{l}{ Glacier wastage and Melt, monthly total in $\mathbf{1 0}^{\mathbf{6}} \mathbf{~ m}^{\mathbf{3}}$} \\
\cline { 2 - 5 } & July & August & September & Sum \\
\hline 1973 & 10.0 & 9.3 & 3.9 & 23.0 \\
1974 & 9.7 & 6.5 & 2.8 & 19.0 \\
1975 & 14.0 & 5.9 & 3.5 & 23.0 \\
1976 & 10.0 & 10.0 & 4.7 & 25.0 \\
1977 & 8.8 & 5.5 & 1.3 & 16.0 \\
Average & 11.0 & 7.5 & 3.2 & $\mathbf{2 1 . 0}$ \\
\hline
\end{tabular}

\subsubsection{Hydrological-hypsometric comparison results}

The average combined glacier wastage and Melt contribution from Peyto Glacier basin using the hydrological-hypsometric comparison method for July to September was $28 \times 10^{6} \mathrm{~m}^{3}$ from 1971-1977. This was $86 \%$ of the observed Peyto Glacier basin streamflow for the same period July to September. The results are shown in Table 5.12.

Table 5.12 Monthly combined glacier wastage and Melt runoff from Peyto Glacier basin x $10^{6} \mathrm{~m}^{3}$ from 1971-1977 estimated by the hydrological-hypsometric method

\begin{tabular}{lllll}
\hline Year & July & August & September & Sum \\
\hline 1971 & 13.0 & 27.8 & 5.8 & 41.4 \\
1972 & 8.2 & 19.1 & 1.5 & 28.8 \\
1973 & 11.0 & 9.6 & 6.6 & 27.0 \\
1974 & 8.6 & 9.6 & 3.8 & 22.0 \\
1975 & 9.7 & 1.3 & 0.8 & 12.0 \\
1976 & 2.4 & 9.4 & 35.0 & 47.0 \\
1977 & 5.9 & 15.0 & 0.2 & 22.0 \\
Average & 8.4 & 13.2 & 6.9 & $\mathbf{2 8 . 4}$ \\
\hline
\end{tabular}




\subsubsection{Volume-Area relationship}

The average annual net glacier wastage from Peyto Glacier basin for 1975-1998 using the volume-area scaling approach was $7.4 \times 10^{6} \mathrm{~m}^{3}$. Observed streamflow data for this period are not available, thus glacier percentage contribution to flow cannot be calculated.

\subsubsection{Mass balance data}

The mass balance data are shown in Table 5.13. The average annual glacier wastage from Peyto Glacier for $1967-1977$ was $8.0 \times 10^{6} \mathrm{~m}^{3}$, estimated as the average mass balance of the negative mass balance years, which was $23 \%$ of the July to September observed flow for the same time period. The average annual combined glacier wastage and Melt (summer mass balance below the ELA) was $18 \times 10^{6} \mathrm{~m}^{3}$, which was $51 \%$ of the July to September observed flow. It therefore appears from these mass balance data that Peyto Glacier Melt alone was on average $10 \times 10^{6} \mathrm{~m}^{3}$ per year, which was $29 \%$ of the observed streamflow from July to September at Peyto Glacier basin from 1967-1977.

Table 5.13 Mass balance of Peyto Glacier 1967-1977 x $10^{6} \mathrm{~m}^{3}$ water equivalent (w.e.). (Average net mass balance applies to the negative net mass balance data only). Source data: Young (1981) and Demuth and Keller (2006).

\begin{tabular}{lll}
\hline Year & \multicolumn{2}{l}{ Mass Balance $\times \mathbf{1 0}^{\mathbf{6}} \mathbf{m}^{\mathbf{3}}$ (w.e.) } \\
\cline { 2 - 3 } & $\begin{array}{l}\text { Summer } \\
\text { (below ELA) }\end{array}$ & Net \\
\hline 1967 & -18 & 0.1 \\
1968 & -12 & 4.8 \\
1969 & -20 & -5.4 \\
1970 & -36 & -23 \\
1971 & -20 & -5.6 \\
1972 & -21 & -3.4 \\
1973 & -14 & 5.8 \\
1974 & -13 & 3.3 \\
1975 & -19 & -7.8 \\
1976 & -11 & 8.7 \\
1977 & -13 & -2.9 \\
Average & $\mathbf{- 1 8}$ & $\mathbf{- 8 . 0}$ \\
\hline
\end{tabular}




\subsubsection{Previous research}

Table 5.14 summarises the results of the average annual glacier wastage and combined glacier wastage and Melt estimated by each of the above methods, and also from the published work of other researchers as described in the literature review of this thesis (section 2.4).

Derikx's work (Derikx 1975, section 2.4.4) is not included in this table since the results are for the month of August only in the year 1970, which is not comparable. The averages in the table do not include the apparently anomalous result of Young's (1982) research, nor the wastage calculated by Wallace (1995) for the early $20^{\text {th }}$ century time period and by Hopkinson and Demuth (2006) for the shorter, early $21^{\text {st }}$ century time period.

Table 5.14 Summary of annual average glacier contribution to streamflow for Peyto Glacier basin estimated by different methods, $\mathrm{x} 10^{6} \mathrm{~m}^{3}$ water equivalent.

\begin{tabular}{lllll}
\hline \multicolumn{2}{l}{ Combined Glacier Wastage and Melt } & \multicolumn{2}{c}{ Mid-late 20 th $^{\text {chntury average: } 24}$} \\
\hline WATFLOOD & $\begin{array}{l}\text { Hydrological } \\
\text { Comparison }\end{array}$ & $\begin{array}{l}\text { Summer Mass } \\
\text { Balance }\end{array}$ & Loijens (1974) & Young (1982) \\
\hline $1973-1977$ & $1971-1977$ & $1967-1977$ & 1971 & $1967-1974$ \\
21 & $\mathbf{2 8}$ & $\mathbf{1 8}$ & $\mathbf{2 8}$ & $\mathbf{1 0}$
\end{tabular}

Glacier Wastage

Mid-late $20^{\text {th }}$ century average: 7.4

\begin{tabular}{llllll}
\hline $\begin{array}{l}\text { Volume - } \\
\text { Area }\end{array}$ & $\begin{array}{l}\text { Net Mass } \\
\text { Balance }\end{array}$ & $\begin{array}{l}\text { Glenday } \\
(1991)\end{array}$ & $\begin{array}{l}\text { Holdsworth et al. } \\
(2006)\end{array}$ & $\begin{array}{l}\text { Wallace } \\
(1995)\end{array}$ & $\begin{array}{l}\text { Hopkinson \& } \\
\text { Demuth (2006) }\end{array}$ \\
\hline $1975-1998$ & $1967-1977$ & $1966-1989$ & $1966-1984$ & $1896-1966$ & $2000-2002$ \\
7.2 & $\mathbf{8 . 0}$ & 7.1 & 7.3 & $\mathbf{1 5}$ & $\mathbf{1 0}$ \\
\hline
\end{tabular}

From these averages it appears that the average glacier wastage in the latter half of the $20^{\text {th }}$ century was $7.4 \times 10^{6} \mathrm{~m}^{3}$ per year, and that Melt was $(24-7.4) 16.6 \times 10^{6} \mathrm{~m}^{3}$ per year.

Average annual Melt was, therefore, greater than wastage thus highlighting the importance of the glacial impact on seasonal streamflow, in terms of effectively delaying snowmelt runoff from May and June and instead augmenting streamflow with ice melt runoff in the later summer 
months. It should be noted that these annual averages of wastage and Melt for the latter half of the $20^{\text {th }}$ century are rough approximations since the results used to calculate the averages are from different time periods.

\subsubsection{Comparison of results}

Whilst the results being compared in Table 5.14 are from different time periods, the average wastage calculated by different methods in the mid to late $20^{\text {th }}$ century is encouragingly similar with regard to using the volume-area approach on a regional scale. The higher wastage estimates from Wallace (1995) for the late $19^{\text {th }}$ early $20^{\text {th }}$ century time period, and Hopkinson and Demuth (2006) for the early $21^{\text {st }}$ century time period are discussed in the next chapter (section 6.5). There are, however, larger differences in the combined wastage and Melt results. There is a $36 \%$ difference between the summer mass balance result $\left(18 \times 10^{6} \mathrm{~m}^{3}\right)$ and the hydrological-hypsometric estimation of combined glacier wastage and Melt $\left(28 \times 10^{6} \mathrm{~m}^{3}\right)$, and also the result estimated by Loijens (1974) (also $28 \times 10^{6} \mathrm{~m}^{3}$ ), and a $11 \%$ difference between the summer mass balance result and the WATFLOOD result $\left(21 \times 10^{6} \mathrm{~m}^{3}\right)$. In each case the summer mass balance result is lower, despite being an overestimation of glacier runoff since it includes snowmelt in the ablation zone, and in addition there is an apparent anomaly of combined glacier wastage and Melt estimated by Young (1982) which is considerably lower still at $10 \times 10^{6} \mathrm{~m}^{3}$ and more comparable to glacier wastage alone, which is on average $7.4 \times 10^{6} \mathrm{~m}^{3}$. These differences are addressed in the sections below. 


\subsubsection{Review of Young's (1982) research}

It is not clear from the literature whether it is solely wastage or combined glacier wastage and Melt that is calculated in Young's (1982) research. The author measures ice ablation and accumulation using stake measurements on the glacier (the net balance of which would be wastage), but also calculates ice and firn melt for snow free areas by linking specific ice melt to mean daily temperature, and using the lapse rate corrected temperature to calculate ice melt (the result of which would be combined wastage and Melt). Further analysis can be made here, if the summer months July to September are isolated and it is assumed that the glacier runoff occurs in these months, the observed streamflow for these months minus the summer precipitation figures (Young 1982) should equal the ice and firn melt. Summer precipitation in Young's work is defined as the snow and rain that falls during May to September thus will include two months extra precipitation, so that the ice and firn melt calculated from subtracting precipitation from streamflow will be an underestimation. Melted winter snow is included as a separate component to the summer precipitation in Young's work, therefore the melt of snow accumulated prior to May (usually occurring in May and June) is not included in this analysis of the July to September months. These figures can be seen in Table 5.15 below. 
Table 5.15 Analysis of glacier runoff calculated by Young (1982), units are x $10^{6} \mathrm{~m}^{3}$ water equivalent.

\begin{tabular}{|c|c|c|c|c|c|c|c|}
\hline \multirow[t]{3}{*}{ Year } & \multicolumn{4}{|c|}{ Young 1982} & \multirow{3}{*}{$\begin{array}{l}\text { HYDAT } \\
\text { Observed } \\
\text { Stream- } \\
\text { flow } \\
\text { (ObSt) } \\
\text { July-Sept }\end{array}$} & \multirow{3}{*}{ 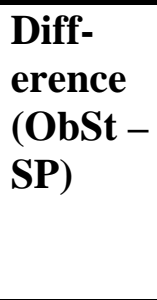 } & \multirow{3}{*}{$\begin{array}{l}\text { Mass } \\
\text { Balance } \\
\text { (Summer } \\
\text { below } \\
\text { ELA) }\end{array}$} \\
\hline & \multirow{2}{*}{ 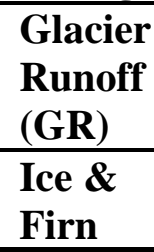 } & \multicolumn{2}{|c|}{$\begin{array}{l}\text { Summer } \\
\text { Precipitation (SP) }\end{array}$} & \multirow{2}{*}{$\begin{array}{l}\text { Sum } \\
\text { (GR + } \\
\text { SP) }\end{array}$} & & & \\
\hline & & $\begin{array}{l}\text { On } \\
\text { Glacier }\end{array}$ & $\begin{array}{l}\text { Off } \\
\text { Glacier }\end{array}$ & & & & \\
\hline 1967 & 10 & 11 & 7.3 & 28 & 42 & 24 & -18 \\
\hline 1968 & 6.2 & 15 & 9.7 & 31 & 37 & 12 & -12 \\
\hline 1969 & 10 & 11 & 7.3 & 28 & 39 & 21 & -20 \\
\hline 1970 & 23 & 7.5 & 4.9 & 35 & 67 & 55 & -36 \\
\hline 1971 & 10 & 10 & 6.6 & 27 & 46 & 29 & -20 \\
\hline 1972 & 8.2 & 18 & 12 & 38 & 42 & 12 & -21 \\
\hline 1973 & 7 & 13 & 8.2 & 28 & 37 & 16 & -14 \\
\hline 1974 & 5.9 & 11 & 7.1 & 24 & 50 & 32 & -13 \\
\hline $\begin{array}{l}\text { Averag } \\
\text { e }\end{array}$ & 10 & 12 & 7.9 & 30 & 45 & 25 & 19 \\
\hline
\end{tabular}

The resulting estimated glacier runoff (average July to September observed streamflow $\left(45 \times 10^{6} \mathrm{~m}^{3}\right)$ - average summer precipitation $\left.\left(12+7.9 \times 10^{6} \mathrm{~m}^{3}\right)\right)$ of $25 \times 10^{6} \mathrm{~m}^{3}$ is much larger, despite being an underestimation of glacier runoff, than those figures given in Young (1982) with an average of $10 \times 10^{6} \mathrm{~m}^{3}$. In addition, it is also larger than the summer mass balance below the ELA estimate of glacier runoff also given in the table with an average of $19 \times 10^{6} \mathrm{~m}^{3}$, despite the summer mass balance below the ELA giving an overestimation of glacier runoff. Also, the glacier runoff (on average $10 \times 10^{6} \mathrm{~m}^{3}$ ) plus the summer precipitation on and off the glacier, assuming it all reaches the stream, (on average $12+7.9=20 \times 10^{6} \mathrm{~m}^{3}$ ) should equal the observed streamflow (on average $45 \times 10^{6} \mathrm{~m}^{3}$ ). Young's numbers, however, fall short by $15 \times 10^{6} \mathrm{~m}^{3}$, which is similar to average Melt calculated in this study of $16.6 \times 10^{6} \mathrm{~m}^{3}$ (Table 5.14), indicating that Young's (1982) measurement is likely glacier wastage alone. In addition, for the warm, dry year of 1970, Young's (1982) estimate of glacier runoff is relatively larger at $23 \times 10^{6} \mathrm{~m}^{3}$ than the average for the latter half of the $20^{\text {th }}$ century, however, it is still smaller than the summer 
mass balance below the ELA in $1970\left(36 \times 10^{6} \mathrm{~m}^{3}\right)$ and is the same as the net mass balance in $1970\left(23 \times 10^{6} \mathrm{~m}^{3}\right.$, Table 5.13) which equates to glacier wastage. All of this analysis indicates that the results from Young (1982) are estimates of glacier wastage alone as opposed to combined glacier wastage and Melt, which corresponds well with the published results of other researchers and the results of this study (Table 5.14).

An analysis of using the summer mass balance below the ELA as an estimate of combined glacier wastage and Melt can be made using Young's data (1982). If summer mass balance below the ELA is a good indicator of combined glacier wastage and Melt, the summer mass balance plus the summer precipitation on and off the glacier should equal the observed streamflow. When dealing with the averages from 1967-1974 (Table 5.14) the numbers are as follows: $19+(12+7.9)$ respectively, equalling $39 \times 10^{6} \mathrm{~m}^{3}$, which is smaller than the observed streamflow average of $45 \times 10^{6} \mathrm{~m}^{3}$ despite the summer mass balance numbers being an overestimate of glacier runoff since snowmelt in the ablation zone is included. This indicates that in the July to September period there is either another input to streamflow other than summer precipitation and glacier runoff as calculated from the summer mass balance below the ELA (therefore including snowmelt from the ablation zone), or there are errors in either the precipitation data (from Young 1982), the summer mass balance data (as an estimate of glacier runoff), or the measured streamflow data. The errors associated with the mass balance field data collection on Peyto Glacier are summarised in Demuth and Keller (2006), in which it is stated that the individual point mass balance measurements are quite accurate with standard errors possibly as low as $10-20 \mathrm{~mm}$ water equivalent. Evolving micro-topography close to the measurement stake such as surface meltwater channels, however, may influence the reliability of the stake measurement, and at larger scales variations in the topography, such as slope and 
aspect, and associated local climate effects complicate the ability of the stake measurement to accurately represent an area average. Demuth and Keller (2006) therefore state that the measured mass balance values should be considered to have a standard error of $150-200 \mathrm{~mm}$ water equivalent. In addition, there are likely some errors in the observed streamflow measurements since the flow at the Peyto Glacier basin stream gauge site in these late summer months was turbulent and rough (Loijens 1974). Indeed, Loijens (1974) reduced the measured streamflow at Peyto Glacier basin gauge for 1971 by $6 \%$ based on calculations of the hydrologic balance for the basin. Further analysis of the methods used to calculate combined glacier wastage and Melt can be conducted by comparing the results from individual years as described in the following section.

\subsubsection{Comparison of annual results}

For a more detailed comparison of the results from those methods for which a yearly estimate of combined glacier wastage and Melt contribution was made, it is possible to look at the WATFLOOD (Table 5.11), hydrological-hypsometric comparison (Table 5.12) and summer mass balance below the ELA (Table 5.13) data for each year of a common time period alongside the observed runoff from Peyto Glacier basin (Table 5.10) as shown in Table 5.16. The combined glacier wastage and Melt estimated by each method is found as a percentage of the observed streamflow, highlighted in bold in Table 5.16. 
Table 5.16 Combined glacier wastage and Melt from Peyto Glacier basin x $10^{6} \mathrm{~m}^{3}$ water equivalent, calculated from three different methods and expressed as a percentage of the observed streamflow.

\begin{tabular}{|c|c|c|c|c|c|c|c|}
\hline \multirow[t]{2}{*}{ Year } & \multicolumn{2}{|c|}{$\begin{array}{l}\text { WATFLOOD } \\
\text { (July to Sept) }\end{array}$} & \multicolumn{2}{|c|}{$\begin{array}{l}\text { Hydrological } \\
\text { comparison } \\
\text { (July-Sept) }\end{array}$} & \multicolumn{2}{|c|}{$\begin{array}{l}\text { Summer mass balance } \\
\text { (below ELA) }\end{array}$} & \multirow[t]{2}{*}{$\begin{array}{l}\text { Peyto gauge } \\
\text { flow } \\
\text { (Jul-Sept) }\end{array}$} \\
\hline & $\mathrm{x} 10^{6} \mathrm{~m}^{3}$ & $\%$ of flow & $\mathrm{x} 10^{6} \mathrm{~m}^{3}$ & $\%$ of flow & $\mathrm{x} 10^{6} \mathrm{~m}^{3}$ & $\%$ of flow & \\
\hline 1971 & & & 41 & 100 & 20 & 49 & 41 \\
\hline 1972 & & & 29 & 88 & 21 & 64 & 33 \\
\hline 1973 & 23 & 74 & 27 & 87 & 14 & 45 & 31 \\
\hline 1974 & 19 & 48 & 22 & 55 & 13 & 33 & 40 \\
\hline 1975 & 23 & 92 & 12 & 48 & 19 & 76 & 25 \\
\hline 1976 & 25 & 71 & 47 & 134 & 11 & 31 & 35 \\
\hline 1977 & 16 & 62 & 22 & 85 & 13 & 50 & 26 \\
\hline
\end{tabular}

There are differences between these annual results likely due to the limitations of each individual method as described in the methodology chapter. A problem with the hydrologicalhypsometric results can be immediately seen in 1976 since the estimated glacier runoff is over $100 \%$ of the observed streamflow, and similarly in 1971 the glacier runoff is $100 \%$ of the streamflow implying incorrectly that there is no summer precipitation in the basin. It is possible that not all the glacier runoff reaches the basin streamflow due to losses in glacier runoff to groundwater systems, evaporation from melt streams on the glacier surface, or refreezing of meltwater in the en-glacial drainage system. These losses of glacier runoff, however, are already accounted for in the hydrological-hypsometric method which estimates glacier runoff as the difference between the observed streamflow of a glacierised and non-glacierised basin, thus the method calculates only the glacier runoff that reaches the stream. In addition, the average summer precipitation (Young 1982) on and off the glacier from 1967-1974 was $20 \times 10^{6} \mathrm{~m}^{3}$, or on average $44 \%$ of the observed streamflow for this time period. This is an overestimation of the summer precipitation contribution to streamflow since it includes precipitation in May and June, 
and if it is assumed that precipitation in July to September is approximately half that from May to September, or $22 \%$ of streamflow, then the high percentage glacier contribution to streamflow of above $80 \%$ estimated by the hydrologic- hypsometric approach in 1971-1973, 1976 and 1977 indicates that this is an overestimation of glacier runoff. For these reasons it appears that the hydrological-hypsometric approach is the least accurate in estimating glacier runoff. Loijens's (1974) estimate of combined glacier wastage and Melt for 1971 of $28 \times 10^{6} \mathrm{~m}^{3}$, or $68 \%$ of the observed flow, can also be compared here. July to September precipitation (assumed to be half that occurring in May to September) in 1971 contributed approximately $20 \%$ of the observed flow (Young 1982), thus the remaining 12\% of observed streamflow is assumed to come from a source other than summer precipitation and glacier runoff. Loijens's estimate of combined glacier wastage and Melt for $1971\left(28 \times 10^{6} \mathrm{~m}^{3}\right)$ is less than the hydrological-hypsometric comparison estimation $\left(41 \times 10^{6} \mathrm{~m}^{3}\right)$, which is inaccurately $100 \%$ of flow, and greater than the summer mass balance estimate $\left(20 \times 10^{6} \mathrm{~m}^{3}\right)$, which includes snowmelt in the ablation zone. Derikx has also completed previous work on Peyto Glacier, including modelling the water balance of the basin in 1968 using an energy balance (Derikx 1971), for which the average modelled runoff July to September $\left(3.57 \mathrm{~m}^{3} \mathrm{~s}^{-1}\right)$ matches well the observed streamflow average for July to September of the same year $\left(3.77 \mathrm{~m}^{3} \mathrm{~s}^{-1}\right.$, Environment Canada WSC: HYDAT), thus it is likely that the calculated glacier runoff is a reasonable estimate. Total glacier contribution (thus combined wastage and Melt) for August 1970 was calculated from the model as a residual from the heat energy balance as $13 \times 10^{6} \mathrm{~m}^{3}$. When this is compared with the average August glacier contribution 1973 -1977 from WATFLOOD $\left(7.4 \times 10^{6} \mathrm{~m}^{3}\right)$ and the hydrologicalhypsometric comparison $\left(9.1 \times 10^{6} \mathrm{~m}^{3}\right)$ (1970 data were not available from these methods), however, Derikx's (1971) figure of $13 \times 10^{6} \mathrm{~m}^{3}$ is much greater. This is likely the result of 1970 
being a particularly warm, dry year which can be seen in the mass balance data for which the net balance was largely negative at $-23 \times 10^{6} \mathrm{~m}^{3}$, thus it would be expected that the glacier runoff would be much greater this year than in other years.

The hydrological-hypsometric approach is considered the least accurate, as demonstrated in the above analysis, and least consistent due to the many method limitations (section 4.4.2) and cannot be used to compare to the volume-area results regionally due to the lack of observed streamflow data. The remaining analysis of results, therefore, focuses on the WATFLOOD and summer mass balance estimates of combined glacier wastage and Melt, as shown in Table 5.17, with the percentage difference between the results calculated.

Table 5.17 Combined glacier wastage and Melt from Peyto Glacier basin estimated using WATFLOOD and the summer mass balance data below the ELA, $x 10^{6} \mathrm{~m}^{3}$ water equivalent

\begin{tabular}{llll}
\hline Year & $\begin{array}{l}\text { Glacier wastage and Melt x } \mathbf{1 0}^{\mathbf{6}} \mathbf{m}^{\mathbf{3}} \text { water } \\
\text { equivalent }\end{array}$ & Difference \% \\
\cline { 2 - 3 } & WATFLOOD & $\begin{array}{l}\text { Summer mass balance } \\
\text { (below ELA) }\end{array}$ & \\
\hline 1973 & 23 & 14 & 39 \\
1974 & 19 & 13 & 32 \\
1975 & 23 & 19 & 17 \\
1976 & 25 & 11 & 56 \\
1977 & 16 & 13 & 19 \\
\hline
\end{tabular}

There are considerable differences of between $17-56 \%$ between the estimates of combined glacier wastage and Melt calculated from the WATFLOOD and summer mass balance methods. WATFLOOD estimated greater glacier runoff in every year of comparison despite the summer mass balance method being an overestimation of glacier runoff since the data also include snowmelt from the ablation zone. It is thought, however, that WATFLOOD also overestimates ice melt mainly because snow is not simulated to remain longer on the glacier ice 
surface relative to the surrounding land surfaces. Whilst both these methods are thought to overestimate glacier runoff, and thus it could be concluded that WATFLOOD grossly overestimates glacier runoff, the combined glacier wastage and Melt estimated by both methods contributed less than $80 \%$ of Peyto Glacier basin streamflow (July to September, Table 5.16) each year, with the exception of WATFLOOD in 1975. Indeed, the summer mass balance estimated glacier runoff contributed less than $50 \%$ of the July to September streamflow in 1971, 1973-4 and 1976, and the WATFLOOD simulated glacier runoff contributed less than 50\% in 1974. Since both these methods assume that all the estimated glacier runoff reaches the stream in July to September, which in reality is not always the case, and thus are considered overestimates of glacier runoff- also as a result of the limitations to each method- these low percentage contributions to the observed streamflow in July to September imply that there are inputs to streamflow other than glacier runoff and summer precipitation, or that there are errors in the data sets. It is possible that there are other inputs to streamflow in the July to September period, such as groundwater, snowmelt from the spring that was delayed in the glacial drainage system, snowmelt from the accumulation zone (snowmelt from the ablation zone is included in the summer mass balance below the ELA glacier runoff estimates), and ice melt from the surrounding ice-cored moraines. Hopkinson and Demuth (2006) estimated ice melt from the downwasting of glacial moraines at Peyto Glacier as $6 \%$ of the total wastage $\left(22 \times 10^{6} \mathrm{~m}^{3}\right)$ for 2000-2002, or $1.32 \times 10^{6} \mathrm{~m}^{3}$ per year. Despite this estimate being for a much later time period, this volume of meltwater is only $3 \%$ of the average observed streamflow from 1967-1974, thus is too small to account for the total differences between observed streamflow and the estimated glacier runoff from WATFLOOD and mass balance data plus summer precipitation. 
There are a lot of possible errors associated with this analysis, in the observed streamflow, mass balance and summer precipitation data sets used, and with the WATFLOOD and summer mass balance below the ELA methods of estimating combined glacier wastage and Melt. In addition, it is difficult to quantify possible runoff delays or re-freezing within the glacier drainage system, groundwater inputs to streamflow or outputs of runoff which do not reach the streamflow and inter-basin flow, all of which would affect the observed streamflow and thus the analysis of glacier contribution. It is therefore difficult to determine, based on this analysis of Peyto Glacier basin with the lack of a verifying measured glacier runoff data set, the ability of WATFLOOD to model glacier runoff and the uncertainties involved. The considerable differences, however, in estimated combined glacier wastage and Melt from WATFLOOD and the summer mass balance approach mean that the results from WATFLOOD of glacier contribution on a regional scale should be treated with caution.

To calculate wastage and Melt as separate components of Peyto Glacier basin streamflow, the wastage estimated as equivalent to the net mass balance (in negative mass balance years) was subtracted from the combined wastage and Melt estimated by both the WATFLOOD and the summer mass balance (below the ELA) methods to give estimates of Melt. The separate wastage and Melt components were found as percentages of the observed streamflow at Peyto Glacier basin for July to September (Table 5.18). For years of positive mass balance no wastage occurred (no wast), thus the WATFLOOD and summer mass balance estimated glacier runoff equalled Melt. 
Table 5.18 Glacier wastage and Melt percentage contribution to Peyto Glacier basin streamflow from July to September, x $10^{6} \mathrm{~m}^{3}$ water equivalent, using both WATFLOOD (WAT) and summer mass balance (S-mb) below the ELA data.

\begin{tabular}{|c|c|c|c|c|c|c|c|c|c|}
\hline \multirow[t]{3}{*}{ Year } & \multirow[t]{2}{*}{ WAT } & \multirow[t]{2}{*}{ S-mb } & \multirow{2}{*}{\multicolumn{2}{|c|}{$\begin{array}{l}\text { Net mass } \\
\text { balance } \\
\text { (wastage) }\end{array}$}} & \multicolumn{4}{|l|}{ Melt } & \multirow[t]{3}{*}{$\begin{array}{l}\text { Peyto } \\
\text { gauge flow } \\
\text { (Jul-Sept) }\end{array}$} \\
\hline & & & & & \multicolumn{2}{|l|}{ WAT } & \multicolumn{2}{|l|}{$\mathrm{S} \mathrm{mb}$} & \\
\hline & $\mathrm{x} 10^{6} \mathrm{~m}^{3}$ & $\mathrm{x} 10^{6} \mathrm{~m}^{3}$ & $\mathrm{x} 10^{6} \mathrm{~m}^{3}$ & $\%$ flow & $\mathrm{x} 10^{6} \mathrm{~m}^{3}$ & $\%$ flow & $\mathrm{x} 10^{6} \mathrm{~m}^{3}$ & $\%$ flow & \\
\hline 1971 & & 20 & -5.6 & 14 & & & 14.4 & 35 & 41 \\
\hline 1972 & & 21 & -3.4 & 10 & & & 17.6 & 53 & 33 \\
\hline 1973 & 23 & 14 & 5.8 & No wast & 23 & 74 & 14 & 45 & 31 \\
\hline 1974 & 19 & 13 & 3.3 & No wast & 19 & 48 & 13 & 33 & 40 \\
\hline 1975 & 23 & 19 & -7.8 & 31 & 15.2 & 61 & 11.2 & 45 & 25 \\
\hline 1976 & 25 & 11 & 8.7 & No wast & 25 & 71 & 11 & 31 & 35 \\
\hline 1977 & 16 & 13 & -2.9 & 11 & 13.1 & 50 & 10.1 & 39 & 26 \\
\hline
\end{tabular}

In every year, wastage was smaller than Melt as estimated by both the WATFLOOD and summer mass balance methods, with WATFLOOD estimating greater volumes of Melt each year relative to the summer mass balance method as previously discussed. Despite the differences observed in this section between combined wastage and Melt calculated by the WATFLOOD and summer mass balance methods, the results of both methods (Table 5.18) show that Melt contributed over $31 \%$ to Peyto Glacier basin streamflow in the July to September months between 1971-1977. The net mass balance data show that wastage contributed over 10\% to July to September streamflow from Peyto Glacier basin in years of negative mass balance.

\subsection{Glacier Contribution Downstream}

The volume-area approach was used to estimate net wastage from 1975-1998 for glaciers of the $\mathrm{N}$ and SSRB, and this was found as a percentage of the observed streamflow at Edmonton and Calgary, respectively. WATFLOOD was used to estimate combined glacier wastage and 
Melt, and the difference between the model results and those from the volume-area method was calculated to give the average annual volume of Melt as an indication of the seasonal impact of Melt on streamflow at Edmonton and Calgary (Table 5.19).

Table 5.19 Glacier wastage and seasonal Melt contribution to streamflow at Edmonton and Calgary from 1975-1998, x $10^{6} \mathrm{~m}^{3}$ water equivalent.

\begin{tabular}{|c|c|c|c|c|c|}
\hline \multirow[t]{2}{*}{ Basin } & \multirow{2}{*}{$\begin{array}{l}\text { Total } \\
\text { observed } \\
\text { flow } \\
1975-1998\end{array}$} & \multicolumn{2}{|c|}{$\begin{array}{l}\text { Wastage } \\
\text { contribution }\end{array}$} & \multirow{2}{*}{$\begin{array}{l}\text { Wastage \& } \\
\text { Melt } \\
\text { contribution } \\
\times 10^{6} \mathrm{~m}^{3}\end{array}$} & \multirow{2}{*}{$\begin{array}{l}\begin{array}{l}\text { Melt } \\
\text { contribution }\end{array} \\
\times 10^{6} \mathrm{~m}^{3} \\
\end{array}$} \\
\hline & & $\mathrm{x} 10^{6} \mathrm{~m}^{3}$ & $\%$ & & \\
\hline $\begin{array}{l}\text { North Saskatchewan } \\
\text { River at Edmonton }\end{array}$ & 149655 & 3939 & 2.6 & 17929 & 13990 \\
\hline $\begin{array}{l}\text { Bow River at } \\
\text { Calgary }\end{array}$ & 64381 & 1799 & 2.8 & 5792 & 3993 \\
\hline
\end{tabular}

The results in Table 5.19 show that whilst the total volume of net wastage from the NSRB was greater $\left(3939 \times 10^{6} \mathrm{~m}^{3}\right)$ than that from the SSRB $\left(1799 \times 10^{6} \mathrm{~m}^{3}\right)$ due to the greater total glacierised area, the percentage contribution at both Calgary and Edmonton was very similar at less than 3\% annually. The WATFLOOD results estimate that combined glacier wastage and Melt at Edmonton was approximately $18000 \times 10^{6} \mathrm{~m}^{3}$ water equivalent, and thus Melt itself, calculated from a comparison of the WATFLOOD and wastage results, was approximately $14000 \times 10^{6} \mathrm{~m}^{3}$ of the total streamflow $150000 \times 10^{6} \mathrm{~m}^{3}$ from $1975-1998$. In Calgary, combined glacier wastage and Melt was approximately $6000 \times 10^{6} \mathrm{~m}^{3}$, with Melt equalling approximately $4000 \times 10^{6} \mathrm{~m}^{3}$ of the total streamflow $64000 \times 10^{6} \mathrm{~m}^{3}$ from 1975-1998. This was not found as a percentage of streamflow since Melt does not contribute to increased total annual streamflow volume and the July to September flow is regulated at Edmonton and Calgary. 


\section{Chapter 6}

\subsection{Discussion}

\subsection{Glacial Impact on Streamflow in the $\mathrm{N}$ and SSRB Headwaters}

From observing summer streamflow hydrographs from 1976-1992 (Figure 5.1), it appears that the more glacierised the basin, the more evident the delay and extension of the summer peak flow, with glacier augmentation most obvious when basin glacier cover is above $3 \%$. Flows from basins with as little as $1 \%$ glacier cover still display slight glacier augmentation, however, below this the glacier cover appears too small to have a noticeable impact on the flow regime. Whilst caution should be taken in attributing the differences in late summer flow regimes to solely glacier augmentation due to differences in basin elevation, climate regime and land cover (section 4.4.2), studies of glacierised basins should consider that glacier decline could impact streamflow from basins with as little as $1 \%$ glacier cover, and it is proposed that non-glacierised basins are defined as those with less than $0.5 \%$ glacier cover.

A comparison of glacierised and non-glacierised (less than $0.5 \%$ glacier cover) basin streamflow coefficients of variation $(C V)$ shows a similar compensation effect to that observed in Fountain and Tangborn (1985), Fleming and Clarke (2005) and to that seen in Hopkinson and Young (1998) for the Bow River at Banff. Glaciers act as natural regulating reservoirs resulting in consistently less variability in streamflow from glacierised basins with respect to nonglacierised basins, both annually and in July to September (Figure 5.2). These results are supported by the results of previous work by Demuth and Pietroniro (2003), which determine an 
increase in August to October streamflow variability from glacierised headwater sub-basins of the NSRB since the mid-1990s in association with decreasing glacier cover. There is no evidence of a minimum streamflow $C V$ at intermediate basin glacier covers; however, this may be due to the low maximum glacier cover of the glacierised basins with available flow data to analyse (15.3\%), which may also explain the low $\mathrm{R}^{2}=0.47$ of the trend line for the relationship between basin glacier cover and streamflow $C V$ in July to September (Figure 5.2). Peyto Glacier basin (62.6\% glacier cover) has summer flow records available for a shorter time period 1971-1977 with a July-September streamflow $C V$ for this period of 0.19 . This is similar to the July to September streamflow $C V$ of the higher glacierised basins Mistaya at Saskatchewan Crossing (0.15), North Saskatchewan at Whirlpool (0.15) and Bow at Lake Louise (0.18), therefore indicating that streamflow $C V$ does not reach a minimum at an intermediate glacier cover. Similar to previous studies with contrary results however (e.g. Moore 1992), the singular point from a short time period is insubstantial evidence to draw a valid conclusion. To summarise, streamflow $C V$, both annually and in July to September, decreases with increasing glacier cover in agreement with the literature, and basins with $1 \%$ glacier cover and above show signs of glacier augmentation in the later summer months, which is especially noticeable for basins with above 3\% glacier cover. Glacier decline therefore has implications for users of glacierised basin streamflow that require a consistent, reliable water supply in the late summer months of otherwise low flow. 


\subsection{Glacier Wastage and Seasonal Melt Contributions}

\subsubsection{WATFLOOD modelled contribution}

There is a strong relationship between percentage basin glacier cover and combined glacier wastage and Melt percentage contribution to streamflow in the July to September months with an $\mathrm{R}^{2}=0.9$ (Figure 5.5), though this is partly a reflection of the representation of glaciers within the model. The relationship is not linear showing a sharp decrease in glacier contribution towards smaller basin glacier covers, perhaps indicating that contribution to flow will decrease at an increasing rate with future glacier decline. This may be influenced by the greater percentage area loss of smaller glaciers (relative to the 1975 cover) in the N and SSRB region (Demuth et al. 2008), which are generally found in the basins of low percentage glacier cover. There is a clear distinction that glaciers contributed above $20 \%$ to streamflow in glacierised basins with above 1\% glacier cover in the July to September period. From 1975-1998 the average glacier contribution to July to September streamflow in the modelled headwater basins of the North Saskatchewan River basin dropped from $61-53 \%$, and from $44-27 \%$ in the South Saskatchewan River basin. With reference to the average climate differences between 1970-1980 and 19932003 (section 5.2), this decrease in glacier contribution to streamflow is likely the result of the reduction in glacier cover, and in spite of climate variations. The climate variables for the later 1993-2003 time period indicated on average drier summers and warmer winters with decreased snowfall relative to the 1970 -1980 time period, which would increase the streamflow proportion of glacier runoff if glacier cover remained constant. The magnitude of these results should be treated with caution due to the unrealistic modelling of glaciers within WATFLOOD (section 4.3.3), and it is proposed that a more physically based, detailed glacier model be used for future studies of glacier wastage and Melt contribution to streamflow, currently prevented from use by 
the lack of data for glaciers of the $\mathrm{N}$ and SSRB. The importance of the timing of these glacier contributions to streamflow in these headwater basins, however, leads to concern over the declining glacier trends and thus water availability in the late summer months of otherwise low flow.

\subsubsection{Hydrological-hypsometric comparison}

From the comparison of glacierised and non-glacierised similar basins, it appears that glacierised basins had an increased specific flow in the late summer months (Table 5.5). For basins with above $9 \%$ glacier cover this difference in flow was greatest in August, whereas for basins with above $6 \%$ glacier cover the difference was greatest in July (Figure 5.6). This maybe due to the increased delay in runoff from larger glaciers, generally found in the basins with greater glacier cover, due to a greater network length of en-glacial channels. Despite the lack of a strong relationship between percentage basin glacier cover and combined glacier wastage and Melt contribution estimated by this approach (Figure 5.7), observations of measured streamflow for the compared basins found greater specific runoff and a lower streamflow $C V$ for the glacierised basins relative to the non-glacierised basins in July to September. The differences in observed streamflow from the basins compared, however, cannot be solely attributed to glacier runoff, since the compared basins likely have differing aspects, precipitation, both in terms of rainfall and summer snowfall, temperatures, affecting snowmelt and evaporation, groundwater systems and land covers, and there may be inter-basin flow, all of which would cause differences in the late summer streamflow. In addition, the lack of a similar non-glacierised basin for comparison meant that a partially glacierised basin had to be used, and there was also a lack of highly glacierised basins (especially in the SSRB) with available observed streamflow data, thus 
in some cases the comparison basins were of similar glacier cover. Indeed, if the basins in each comparison had exactly the same hypsometry and climate regime, they would either both be glacierised or non-glacierised. In terms of differences in hypsometry, however, it is thought that glacier cover rather than hypsometry primarily accounts for the differences between glacierised and non-glacierised basin flows (Fountain and Tangborn 1985, Fleming 2005). Whilst these results are not used to draw conclusions concerning combined glacier wastage and Melt contribution to streamflow, the estimates of glacier contribution are useful to compare to the results of other methods, especially the WATFLOOD results, since the lack of data for the glaciers of the $\mathrm{N}$ and SSRB prevent other approaches, such as mass balance modelling, from being used to estimate glacier contribution.

\subsection{Glacier Wastage Contribution to Flow}

Net glacier wastage from 1975-1998 as calculated by the volume-area approach contributed over $10 \%$ of streamflow in a number of basins of the N and SSRB especially in the July to September period of otherwise low flow (Table 5.7). It was generally observed that the glacier wastage contribution to flow increased with increasing percentage basin glacier cover (Figure 5.8), due to the greater area of ice in the basin available for melting. It was difficult to determine a relationship between percentage basin glacier cover and wastage percentage contribution for the SSRB due to the small range of glacier cover amongst the basins of 0.02$8.4 \%$. Whilst the range of glacier cover in the NSRB was greater $(0.2-58 \%)$, every basin had a glacier cover of less than $20 \%$ with the exception of one (Peyto Glacier basin) thus the relationship was influenced by this high outlier. In addition, whilst larger glaciers produced greater volumes of wastage runoff from 1975-1998, the smallest glaciers in this region have lost 
the greatest percentage area relative to their 1975 extent (Demuth et al. 2008), thus this may also affect the relationship. There were anomalies to this relationship which may be partly due to the variations in specific wastage from individual glaciers which depends on local and regional climate, topography and glacier attributes (section 2.2.3). Indeed, large differences are seen in the percentage glacier volume loss from 1975-1998 for the headwater basins of both the $\mathrm{N}$ and SSRB indicating that the glaciers are declining at varying rates. For example a glacier located on a north facing slope, with higher elevation, a local climate regime and topographic conditions resulting in plentiful precipitation falling as snow and accumulating on the glacier, with snowdrifts, avalanching or blowing snow also supplying the glacier, will experience considerably less wastage, if any, than a similar sized glacier on a south facing slope with little snow accumulation. This individual glacier response likely explains some of the differences in wastage percentage contribution for basins with similar percentage glacier cover. Variations in percentage wastage contribution, however, will also result from differences in the relative proportion of streamflow to glacier runoff arising from differences in local precipitation regimes and land cover. Future wastage contribution is also likely to vary as declining glaciers generally experience an accelerated rate of diminution due to their larger volume-area ratio (Granshaw and Fountain 2006, Demuth et al. 2008). Thus, whilst the effects of glacier wastage contribution to flow can be generalised according to a relationship between percentage basin glacier cover and contribution, this could be very misleading. Streamflow users concerned with glacier decline, therefore, should look for research on their specific basin and the glaciers within, and understand that estimates of glacier wastage apply to the climate of the time period over which the study was conducted. 
Glacier area mapping work by Young (1991) suggests that annual glacier wastage contributions to the Mistaya River averaged 6\% for the period 1967-1986. Similarly, Henoch (1971) calculated glacier wastage for the whole upper North Saskatchewan River basin (North Saskatchewan at Saskatchewan Crossing and Mistaya River sub-basins) from 1948-1966 and estimated that glacier contribution was $6 \%$ of the annual streamflow for this period. These previous results compare well with the 1975-1998 annual average net wastage contribution to the Mistaya River of $7.8 \%$ estimated by the volume-area method (Table 5.7). It appears that average wastage contribution does not vary much between the different study time periods and between methods, and supports the use of the volume-area relationship at a regional scale on the glacierised headwater basins of the N and SSRB. Loijens (1974) also calculated glacier wastage to the Mistaya River at Saskatchewan Crossing as $29 \times 10^{6} \mathrm{~m}^{3}$, or $31 \%$ of the July to September streamflow and $14 \%$ of the annual streamflow in 1971. This was calculated from extrapolating the mass balance of Peyto Glacier to other glaciers in the basin, and is a much larger estimate of glacier wastage contribution than the volume-area result of $13 \%$ in July to September and $7.8 \%$ annually, and of the work by Young (1991) and Henoch (1971). These differences could be due to errors in the research methods of Loijens (1974), or the result of 1971 possibly being a year of larger wastage (following the warm, dry year of 1970) relative to the average of the time periods studied by the other methods over a number of years. In addition, Hopkinson and Young (1998) calculated glacier wastage as 3.3\% of the flow at the Bow River at Banff from 1975-1993 (directly obtained from the table data published within the paper) which is very similar to the 2.2\% average annual net wastage calculated from the volume-area approach from 1975-1998. Hopkinson and Young (1998) used the same volume-area scaling relationship thus the results are 
expected to be very similar, with differences likely due to differing time periods and methods of glacier cover measurement.

\subsection{Implications of the Differences between Glacier Wastage and Melt}

The similarity of the WATFLOOD and hydrological-hypsometric comparison results

(Figure 5.9), and the large difference between these and the results of the volume-area approach (Table 5.9), strongly suggest that glacier wastage and Melt are very different components of glacier runoff and should be treated as such. The separation of these two components of glacier contribution has implications concerning the volume of streamflow when glaciers are in equilibrium or advancing, in which case there would be no wastage contribution and glacier contribution would be significant only on a seasonal time scale in terms of Melt, as opposed to when glaciers are receding, in which case wastage would contribute to the total annual volume of flow, in addition to the seasonal impacts of Melt runoff. Melt was significantly correlated to percentage basin glacier cover (Figure 5.10), and contributed a greater proportion of streamflow in July to September relative to wastage from 1975-1998. Whilst wastage contributions varied due to the individual response of glaciers to climate change and contributed less than $10 \%$ annually and no more than $22 \%$ of the July to September flow from 1975-1998, Melt was a large component of seasonal flow contributing on average $42 \%$ in July to September for basins with between 2 and $8 \%$ glacier cover, and over $60 \%$ of flow for basins with over $10 \%$ glacier cover (Table 5.9). The main impact of future projected glacier decline, therefore, is expected to be manifest in the timing of flow as opposed to the total annual volume, with a decline in late summer streamflow as peak flows shift towards a non-glacierised snowmelt regime hydrograph and the ability glaciers to delay runoff decreases (assuming post-glacial basin conditions, such as 
potential lake formation, do not similarly delay snowmelt runoff). A long term decrease in total streamflow volume is also expected due to a long-term decline in glacier wastage, which also contributes to flow in the late summer months thus compounding the impact of reduced flows. It is thought that the majority of glaciers in the region are past the increased flow phase due to increased wastage, thus short term reductions in total annual streamflow volumes are also expected despite projected temperature increases which may increase the specific ice melt rate. These projected reduced late summer flows are a concern for streamflow users such agriculture and hydropower industries which rely on the augmented glacier-fed streamflow in this period of otherwise very low flow. In addition, should glaciers continue to decline and reach a new equilibrium, thus fluctuate around a zero mass balance, glacier wastage will no longer contribute to streamflow, and the main component of flow in the late summer months will be Melt originating from glaciers. This will be equal in volume water equivalent to the snow on the glacier that does not melt in a glacier year and instead accumulates into the glacier system, and a smaller glacier will accumulate less snow and thus produce less Melt runoff. This raises concerns over future water availability in these headwater basins in the later summer months of otherwise low flow even if glaciers are to reach a new equilibrium in the future, as opposed to continued decline and possible disappearance in which case a non-glacierised snowmelt flow regime would result with a dramatic reduction in flow in the late summer.

\subsection{Peyto Glacier Basin Glacier Runoff}

A summary of the previous work completed on Peyto Glacier and basin is presented in the literature review of this thesis (section 2.4), and the results can be compared to those calculated in this thesis (Table 5.14). Wastage from Peyto Glacier calculated by a number of 
methods and compared to the published work of other researchers for the latter half of the $20^{\text {th }}$ century was very similar (Table 5.14), indicating that average wastage did not change much between study time periods and between methods. The similarity of results also supports the use of the volume-area relationship to calculate wastage at a regional scale on the glacierised headwater basins of the $\mathrm{N}$ and SSRB. The estimate of average annual wastage calculated by Wallace (1995) of $15 \times 10^{6} \mathrm{~m}^{3}$ for the earlier time period of the late $19^{\text {th }}$ and first half of the $20^{\text {th }}$ centuries, is larger than the average for the late $20^{\text {th }}$ century, which could be the result of Peyto having a larger glacier area in this earlier time period. Hopkinson and Demuth's (2006) annual wastage estimate for the more recent 2000-2002 time period of $10 \times 10^{6} \mathrm{~m}^{3}$ is, however, slightly higher than the average wastage estimate for the late $20^{\text {th }}$ century. This could imply that the decreasing Peyto Glacier area has not yet reached the threshold where it limits the volume of glacier wastage produced, even if higher specific melt rates are maintained (Moore and Demuth 2001). Alternatively, this larger wastage estimation could be the result of applying more accurate wastage measurement techniques, since Hopkinson and Demuth (2006) used high resolution LiDAR imagery which calculates both area loss and surface downwasting. Indeed, net mass balance data indicated an average annual net volumetric loss of $8.5 \times 10^{6} \mathrm{~m}^{3}$ from $2000-2002$, which is more consistent with the average wastage estimated for the late $20^{\text {th }}$ century by a variety of methods, including the calculation of wastage using net mass balance data from 1967-1977 of $8.0 \times 10^{6} \mathrm{~m}^{3}$. In addition, the other methods used to calculate wastage (Table 5.14) did so over longer time periods of over ten years, therefore it is highly likely that annual wastage varied around this average depending on climate variations, for example according to the net mass balance data in 1970 (a particularly warm, dry year) wastage was $23 \times 10^{6} \mathrm{~m}^{3}$. This higher wastage volume calculated by Hopkinson and Demuth (2006) may, therefore, only be a 
reflection of improved technology and a shorter time period of calculation, rather than an indication of increased wastage from Peyto Glacier over time.

Unfortunately, streamflow records for Peyto Glacier basin cannot be analysed to determine whether flows are decreasing or increasing as an indication of varying wastage contributions due to the lack of a continuous, long term record, with reliable data available from 1968-1977 only (Schuster and Young 2006). Given the evidence from other research of decreasing streamflow trends in the late summer months for this region, (e.g. for the NSRB, Demuth and Pietroniro 2003) it may be that whilst Peyto Glacier is large enough still that it has not reached the decreasing wastage with decreasing area phase, the many other smaller glaciers in the region have. Alternatively, the decreasing seasonal late summer trends in the region may be the result of decreasing Melt runoff as less snowfall accumulates into the glacier system and the volume of ice stored in the glacier available for melting post-snowmelt is reduced, masking possible increased seasonal wastage contributions to streamflow. It may therefore be that whilst glacier wastage is possibly increasing from Peyto Glacier, seasonal Melt contributions are decreasing with the decreased glacier area, and since Melt is the larger component of glacier runoff the basin streamflow trends in the late summer months may be declining. Thus, whilst generalisations and relationships between glacier contribution to streamflow and basin glacier cover or individual glacier surface area can be made, streamflow users concerned with future water supplies should focus on the trends and glacier contribution of the specific basin with which they are concerned since the individual response of glaciers could result in different streamflow variations for the same regional climate change.

A comparison of the yearly results of combined glacier wastage and Melt indicates that WATFLOOD produces more reliable estimates than the hydrological-hypsometric approach with 
reference to the observed streamflow from the basin (Table 5.16). There were considerable differences between the estimates of combined glacier wastage and Melt from WATFLOOD and the summer mass balance below the ELA approach (Table 5.17), both of which are expected to be overestimates of glacier runoff due to limitations of each method. The glacier runoff results of both, however, contributed low percentages of the July to September observed flow from Peyto Glacier basin in a number of years, in which time period glacier runoff is expected to be the main contributor to streamflow, indicating that perhaps the glacier runoff results are underestimates. There are potential errors involved in the mass balance, streamflow, summer precipitation and glacier runoff data used, and the lack of measured combined glacier wastage and Melt data with which to verify results and produce uncertainty estimates makes it difficult to conclude from this analysis whether WATFLOOD can be used to accurately simulate glacier runoff on a regional scale. The results from WATFLOOD regionally, and therefore the estimates of Melt contribution, should be treated with caution.

\subsection{Glacier Contribution at Edmonton and Calgary}

Headwater glacier contribution is expected to be large due to the relatively small basin areas and larger percentage basin glacier cover relative to gauging stations further downstream and their contributing basins. Downstream, however, the increasing contributions of rainfall and snowmelt runoff with increasing basin area tend to reduce the relative importance of glacier contribution. At Edmonton and Calgary, net glacier wastage contributed less than 3\% of streamflow from 1975-1998 (Table 5.19) suggesting that in terms of total annual streamflow volume future glacier decline is not a large concern in terms of water supply at these cities. In years of low flow such as drought years, however, glacier wastage contribution may be more 
important since increased temperatures and reduced precipitation will increase wastage and reduce summer streamflow. There are, however, no regional wastage estimates for individual years so this cannot be calculated. Since glacier contribution will continue to decrease downstream relative to the increasing total streamflow volume, it can be assumed that future glacier decline in terms of glacier wastage contributions is not a concern for general water supply on the Prairies, with the possible exception of extreme drought years. The volume of Melt was calculated downstream as $13990 \times 10^{6} \mathrm{~m}^{3}$ at Edmonton and $3993 \times 10^{6} \mathrm{~m}^{3}$ at Calgary (water equivalent) from 1975-1998. Melt affects the timing of the flow, with this volume of water entering the streamflow in the late summer months, generally between July and September, or perhaps October given the lag time to reach these downstream stations, rather than if it entered as snowmelt occurring in May and June. Since streamflow is regulated downstream, the effects of glacier decline and thus the advance of this volume of water to the earlier spring and summer months could potentially be mitigated if reservoir capacities are large enough to store sufficient volumes of water for release in the late summer months of declining flows. It should also be noted that since wastage also contributes to flow in the late summer months, the decrease in late summer streamflow due to Melt advancement will be compounded by long term decreases in wastage contributions.

The impact of glacier decline in terms of the advancement of peak flow is assuming that as glaciers decline, there will be no other system to delay the snowmelt runoff to later in the summer, which is an unrealistic assumption since it is possible that new lakes and wetlands may form as glaciers decline depending on the basin topography and drainage, which will have the effect of delaying basin runoff. The routing of water through groundwater systems may also delay runoff, and previous research has shown that groundwater can be a major component of the 
water balance of alpine lakes, and that the presence of a course overburden deposit, such as a glacial moraine, in contact with an alpine lake can potentially be an important factor in groundwater exchange which occurs through the coarse material (Roy and Hayashi 2008). This thesis, therefore, does not predict exactly what will happen as the result of glacier decline and possible disappearance, but instead estimates the volume of water reaching streamflow as the result of glacier wastage, and the volume of water delayed from reaching streamflow until the late summer months, Melt, as the result of the presence of the 1975-1998 glacial system. The potential impacts of variations in the volume and timing of these glacier contributions to streamflow can then be assessed by streamflow users depending on the volume of flow necessary for use and when the water is required. 


\section{Chapter 7}

\subsection{Conclusions}

A feasible regional approach has been developed and applied to quantify the effects of glacier decline on streamflow in the North and South Saskatchewan River basins. The difference between glacier wastage and Melt has been demonstrated alongside the need to treat these as separate components of glacier runoff, with wastage variations affecting the total streamflow volume and Melt variations affecting the timing of flow. Melt was significantly positively correlated with basin glacier cover in the headwaters of the N and SSRB from 1975-1998. Wastage for the same time period, however, varied between basins of similar glacier cover due to the individual response of glaciers to regional climate variations, and contributed less than $10 \%$ annually and no more than $25 \%$ of the July to September flow. Melt contributed on average $42 \%$ to July to September streamflow for basins with glacier cover ranging from $2-8 \%$, and over $60 \%$ of flow for basins with over $10 \%$ glacier cover from 1975-1998. The larger contributions of Melt relative to wastage indicate that the main impact of future projected glacier decline will be manifest in the timing of flow as opposed to changes in the total volume, with a decline in late summer streamflow as peak flows shift towards a non-glacierised snowmelt regime hydrograph and the ability of the glacier to delay snowmelt decreases (assuming basin runoff is not delayed by other means such as groundwater systems, post-glacial lakes and land cover changes).

A long term decrease in total streamflow volume is also expected due to a decline in glacier wastage, which also contributes to flow in the late summer months thus compounding the 
impact of reduced flows. It is thought that the majority of glaciers in the region, in particular those with a smaller surface area, are past the increased flow phase due to increased wastage, thus short term reductions in total streamflow volumes are also expected despite projected temperature increases. It is possible that this is not true of the larger glaciers, though decreases in Melt contribution to streamflow in the late summer months could offset any increases in wastage contribution as a result of declining glacier area. These projected reduced late summer flows, and also the increase in annual and seasonal streamflow variability as a result of glacier decline, are a concern for streamflow users such as agricultural and hydropower industries, which rely on the augmented glacier-fed streamflow in the late summer months of otherwise very low flow. The individual response of glaciers to regional climate change, however, means that streamflow users should focus on the trends and glacier variations of their specific basin of concern.

Downstream at Edmonton and Calgary, it is estimated that glacier wastage contributed only $3 \%$ of the annual flow from $1975-1998$, and streamflow is regulated so that peak spring flows can be stored and released in the late summer months of otherwise low flow. Future glacier decline, therefore, is not expected to have a large impact on the total streamflow volume downstream from the headwater basins of the $\mathrm{N}$ and SSRB, with the possible exception of extreme drought years. The volume of Melt estimated at Calgary was double that of wastage, and at Edmonton was nearly four times greater than the volume of wastage from 1975-1998. With glacier decline resulting in an advance of this Melt runoff to earlier in the spring as the ability of the glacier to delay snowmelt decreases, a shortage of water in the late summer months, especially in Edmonton, could result if reservoir capacities are incapable of storing sufficient volumes of the spring peak runoff to release and meet demands in the late summer months of otherwise low flow. 
Finally, there is a substantial amount of uncertainty involved in the data input and methods used in this thesis which could not be quantified due to the lack of verification glacier runoff data. Difficulties arise when attempting to calculate errors for regional scale hydrological modelling studies. For example, an attempt to quantify uncertainties for the water balance of the Great Lakes region, which has extensive field data relative to the N and SSRB region, determined that estimating the uncertainty in total-runoff calculations is currently difficult or impossible (Neff and Nicholas 2005). In order to do so, statistical statements for total uncertainty streamflow estimates for all gauges are needed, but streamflow uncertainty is highly variable over space and time thus this would need to be calculated annually for individual gauges, if not monthly. In addition, the reliability of current methods used to estimated runoff in ungauged basins needs to be examined and statements of uncertainty developed (Neff and Nicholas 2005). The lack of observed data for components of the water balance prevents estimates of uncertainty being made, and since these estimates vary greatly in space and time it is currently impossible to conclusively determine uncertainty in the estimates of glacier runoff for this regional study.

The major limiting factors to this research were the lack of glacier mass balance measurements and continuous, long term, measured streamflow data. It is recommended that mass balance programs are implemented on an increased number of glaciers, the results of which can be used to calculate glacier wastage and estimate total glacier runoff in addition to monitoring the response of glaciers to climate change. Additional ice thickness surveys for glaciers in the Canadian Rocky Mountains would be useful to make the $V$-A relationship more rigorous and assist in quantifying the uncertainty. It is recommended that additional meteorological stations be established at higher altitudes where glaciers are located to avoid the interpolation of data. It is vital that the current streamflow gauges in the Canadian Rockies are 
sustained, and highly recommended that additional gauges are added to the monitoring program in order to assess streamflow trends in association with glacier decline. It is critical that basins containing glaciers for which mass balance data are collected, such as Peyto Glacier, are instrumented with a streamflow gauge in order to monitor flow variations corresponding to mass balance changes and assist in closing the water balance. The lack of streamflow measurements for Peyto Glacier basin was a major limiting factor in this thesis, and will continue to limit research on glacier hydrology in the Canadian Rockies since Peyto Glacier is one of the few glaciers for which there is extensive mass balance data.

Improvements to the WATFLOOD model for use on the N and SSRB could be made if an increased number of streamflow gauges for highly glaciated basins were available for calibration, and meteorological data from higher altitudes were available to improve the climate data interpolation across the region. In addition, the testing and verification of melt factors for snow and glacier ice is recommended and requires field study data to do so. To improve the modelling of glaciers within WATFLOOD, a glacier cover variation algorithm is recommended so that glaciers respond to climate changes within the model. Simulated glacier ice melt could be improved if glacier specific snowcover depletion curves were used to reduce the rate of snowmelt from an ice surface relative to bare rock and account for glacier accumulation areas, this would prevent over-estimation of ice melt volumes. These are relatively small changes that could be made to the current GRU approach model, rather than attempting to include individual glaciers as a dynamic system (e.g. Oerlemans et al. 1998 dynamic ice-flow model) which would require additional glacier surface slope, depth, snowline or mass balance data and high resolution climate data inputs which is not feasible for a regional scale study. 
Variations in glacier runoff and the implications of glacier decline on streamflow is a critical issue. The lack of glacier mass balance measurements over varying glacier size and situation, and poor streamflow observation networks in the N and SSRB implies that modelling is required to investigate this issue. It is, however, critical that streamflow, meteorological and glacier mass balance observation networks are continued and extended to assist in closing the water balance, improving the modelling work through providing temporally and spatially extensive data for input, calibration, validation, and uncertainty estimates, and assessing streamflow variations associated with glacier decline. 


\section{List of References}

Anderson, E.A. 1973. National Weather Service River Forecast System - Snow Accumulation and Ablation Model. National Oceanographic and Atmospheric Administration (NOAA), Silver Springs, Maryland, Technical Memorandum NWS HYDRO-17.

Anderson, E.A. 1976. A point energy and mass balance model of a snow cover. National Oceanographic and Atmospheric Administration (NOAA), Technical Report NWS 19.

Arnold, N.S., Willis, I.C., Sharp, M.J., Richards, K.S. and Lawson, W.J. 1996. A distributed surface energy-balance model for a small valley glacier. I. Development and testing for Haut Glacier d'Arolla, Valais, Switzerland. Journal of Glaciology 42: 77-89.

ASCE. (1969). Design and construction of sanitary and storm sewers. Manuals Report. No. 9, ASCE, New York.

Bahr, D.B., Meier, M.F. and S.D. Peckham. 1997. The physical basis of glacier volume-area scaling. Journal of Geophysical Research 102 (B9): 20355-362.

Bahr, D.B., Pfeffer, W.T., Sassolas, C. and Meier, M.F. 1998. Response time of glaciers as a function of size and mass balance: 1. Theory. Journal of Geophysical Research - Solid Earth 103 (B5): 9777-9782. 
Barnett, T.P., Adam, J.C. and Lettenmaier, D.P. 2005. Potential impacts of a warming climate on water availability in snow-dominated regions. Nature 438: 17.

Benn, D.I. and Evans, D.J.A. 2008. Glaciers and Glaciation. Wiley Publishers, New York.

Beven, K.J. 1993. Prophecy, reality and uncertainty in distributed hydrological modelling. Advances in Water Resources 16: 41-51.

Beven, K.J. and Binley, A.M. 1992. The Future of Distributed Models: Model Calibration and Predictive Uncertainty. Hydrological Processes 6: 279-298.

Bingeman, A.K., Kouwen, N. and Soulis, E.D. 2006. Validation of the Hydrological Processes in a Hydrological Model. Journal of Hydrological Engineering 11 (5): 451-463.

Bitz, C.M. and Batistti, D.S. 1999. Inter annual to decadal variability in climate and the glacier mass balance in Washington, Western Canada, and Alaska. Journal of Climate 12: 3181-96.

Bonsal, B.R., Zhang, X. and Hogg, W.D. 1999.Canadian Prairie Growing Season Precipitation Variability and Associated Atmospheric Circulation. Climate Research 11: 191-208.

Bonsal, B.R., Prowse, T.D. and Pietroniro, A. 2003. An assessment of global climate modelsimulated climate for the western cordillera of Canada (1961-90). Hydrological Processes 17: 3703-3716. 
Braithwaite, R.J. 1995. Positive degree-day factors for ablation on Greenland ice sheet studies by energy-balance modelling. Journal of Glaciology 41: 153-160.

Braithwaite, R.J., Olesen, O.B. and Thomsen, H.H. 1992. Calculated variations of annual ice ablation at the margin of the Greenland ice sheet, West Greenland, 1961-90. Journal of

Glaciology. 38: 266-272.

Braithwaite, R.J. and Zhang, Y. 1999. Modelling Changes in Glacier Mass Balance That May Occur as a Result of Climate Changes. Geograpfiska Annaler. Series A, Physical Geography $\mathbf{8 1}$ (4): 489-496.

Braun, L.N. and Escher-Vetter. H. 1996. Glacial discharge as affected by climate change. Internationales Symposion - Interpraevent 1996 - Garmisch-Partenkirchen.

Tagungspublikation 1:65-74.

Brocklehurst, S.H. and Whipple, K.X. 2004. Hypsometry of glacierised landscapes. Earth Surface Processes and Landforms 29: 907-926.

Brubaker, K.L. and Rango, A.1996. Response of snowmelt hydrology to climate change. Water Air and Soil Pollution 90 (1-2): 335-343.

Burgess, D.O. and Sharp, M.J. 2004. Recent changes in aerial extent of the Devon Ice Cap, Nunavut, Canada. Arctic Antarctic and Alpine Research 36 (2): 261-271. 
C-CIARN. 2006. Canadian Climate Impacts and Adaptation Research Network forum on Water Resources, Hydropower and Climate Change, Winnipeg, Canada. http://www.cciarn.mcgill.ca/completed.html.

Chen, J. and Ohmura, A. 1990a. Estimation of Alpine glacier water resources and their change since the 1870s. Hydrology in Mountainous Regions. I- Hydrological Measurements; the Water Cycle. Proceedings of two Lausanne Symposia, August 1990. IAHS Publication No.193.

Chen, J. and Ohmura, A. 1990b. On the influence of Alpine glaciers on runoff. Hydrology in Mountainous Regions. I- Hydrological Measurements; the Water Cycle. Proceedings of two Lausanne Symposia, August 1990. IAHS Publication No.193.

Clarke, G.K.C. 2005. Subglacial Processes. Annual Review of Earth and Planetary Sciences 33: $247-76$.

Collier, E.P. 1958. Glacier Variation and Trends in Run-off in the Canadian Cordillera. IAHS Publication No. 46.

Conly, F.M. and van der Kamp,G. (2001). Monitoring the Hydrology of Canadian Prairie Wetlands to Detect the Effects of Climate Change and Land Use Changes. Environmental Monitoring and Assessment, 67(1-2): 195-215. 
Debeer, C.M. and Sharp, M.J. 2007. Recent changes in glacier area and volume within the southern Canadian Cordillera. Annals of Glaciology 46.

Demuth, M.N. 1996. The Canadian glacier variations monitoring and assessment network: status and future perspectives, p.37-51. In Williams, R.S. Jr. and Ferrigno, J.G. (eds.), Proceedings of the Workshop on Long-term Monitoring of Glacier Fluctuations in North America and Northwestern Europe, Tacoma, U.S.A., September 11-13,1996. United States Geological Survey 98-31 Open-File Report.

Demuth, M.N. and Keller, R. 2006. An assessment of the mass balance of Peyto Glacier (1966$1995)$ and its relation to recent and past-century climatic variability. In - Peyto Glacier: 153 One Century of Science, Demuth, M.N., Munro, D.S. and Young, G.J. (eds.). National Hydrology Research Institute Science Report 8:83-132.

Demuth, M.N. and Pietroniro, A. 1999. Inferring glacier mass balance using RADARSAT: Results from Peyto Glacier, Canada. Geografiska Annaler. Series A, Physical Geography 81A (4): $521-540$.

Demuth, M.N. and Pietroniro, A. 2003. The impact of climate change on the glaciers of the Canadian Rocky Mountain eastern slopes and implications for water resource-related adaptation in the Canadian prairies, "Phase 1" - Headwaters of the North Saskatchewan River Basin. Report to the Climate Change Action Fund - Prairie Adaptation Research Collaborative, PARC. Project P55. Geological Survey of Canada Open File 4322. 
Demuth, M.N., Pinard, V., Pietroniro, A., Luckman, B.H., Hopkinson, C., Dornes, P. and Comeau, L. 2008. Recent and past-century variations in the glacier resources of the Canadian Rocky Mountains - Nelson River System. In - Mountain glaciers and climate changes of the last century. Special 10th Anniversary Issue Terra Glacialis Special Issue - Mountain Glaciers and Climate Changes of the Last Century, 27-52.

Derikx, L. 1975. The heat balance and associated runoff from an experimental site on a glacier tongue. Snow and Ice Symposium (Proceedings of the Moscow Symposium, August 1971) IAHS Publication No.104.

Derikx, L. 1973. Glacier discharge simulations by ground-water analogue. IUGG Hydrology of Glaciers (Proceedings of the Cambridge Symposium, Sept 1969) p29-40. IAHS Publication No. 95.

Dyurgerov, M.B. and Meier, M.F. 2000. Twentieth century climate change: Evidence from small glaciers. Proceedings of the National Academy of Sciences (PNAS) 97: 1406-1411.

Eaton, J.G. and Scheller, R.M. 1996. Effects of climate warming on fish thermal habitat in streams of the United States. Limnology and Oceanography 41:1109-115.

EnSim Hydrologic. Visualization and Analysis for Hydraulic Applications.V2.4 Canadian Hydraulics Centre (CHC) and National Research Council (NRC).1998-2007. 
Environment Canada-Water Survey of Canada. 2008. Canadian hydrometric data: HYDAT CDROM. (http://www.wsc.ec.gc.ca/hydat/H2O/index_e.cfm?cname=main_e.cfm)

Fleming, S.W. 2005. Comparative Analysis of Glacial and Nival Streamflow Regimes with Implications for Lotic Habitat Quantity and Fish Species Richness. River Research and Applications 21: 363-379.

Fleming, S.W. and Clarke, G.K.C. 2003. Glacial Control of Water Resource and Related Environmental Responses to Climatic Warming: Empirical Analysis Using Historical Streamflow Data from Northwestern Canada. Canadian Water Resources Journal 28 (1): 69-85.

Fleming, S.W. and Clarke, G.K.C. 2005. Attenuation of High-Frequency Interannual Streamflow Variability by Watershed Glacial Cover. Journal of Hydraulic Engineering 131: 615-618.

Fleming, S.W., Moore, R.D. and Clarke, G.K.C. 2006. Glacier-Mediated Streamflow Teleconnections to the Arctic Oscillation. International Journal of Climatology 26: 619-636.

Flowers, G.E. and Clarke, G.K.C. 2002a. A multicomponent coupled model of glacier hydrology 1. Theory and synthetic examples. Journal of Geophysical Research 107: B11, 2287.

Flowers, G.E. and Clarke, G.K.C. 2002b. A multicomponent coupled model of glacier hydrology 2. Application to Trapridge Glacier, Yukon, Canada. Journal of Geophysical Research 107: B11, 2288. 
Fohn, P.M.B. 1973. Short-term snow melt and ablation derived from heat- and mass- balance measurements. Journal of Glaciology 12 (65): 275-289.

Fountain, A.G., Jacobel, R.W., Schlichting, R. and Jansson, P. 2005. Fractures as the main pathways of water flow in temperate glaciers. Nature 433: 618-621.

Fountain, A. and Tangborn, W.V. 1985.The effect of glaciers on streamflow variations. Water Resources Research 21(4): 579-586.

Foutain, A. and Tangborn, W.V. 1985. Overview of contemporary techniques. International Association of Hydrological Sciences 149: 27-41.

Fountain, A. and Walder, J.S. 1998. Water flow through temperate glaciers. Review of Geophysics 36 (3):299-328.

Furbish, D.J. and Andrews, J.T. 1984. The use of hypsometry to indicate long-term stability and response of valley glaciers to changes in mass transfer. Journal of Glaciology 30: 105.

Glenday, P. 1991. Determination of morphologic and volumetric change, Peyto Glacier, Alberta, 1966-1989. M.Sc. Masters Thesis, Wilfrid Laurier University, 130 p. 
Goodison, B. 1972. An Analysis of Climate and Runoff Events for Peyto Glacier, Alberta. Scientific Series No 21. Environment Canada. Inland Waters Directorate, Water Resources Branch, Ottowa.

Goodman, R.H. 1975. Radio-echo sounding on temperate glaciers. Journal of Glaciology 14: 57 69.

Gottlieb, L. 1980. Development and applications of a runoff model for snow covered and glacierized basins. Nordic Hydrology 11(5): 255-272.

Green, W.H., and Ampt, G.A. 1911. Studies in soil physics. I: Flow of air and water through soils. Journal of Agricultural Resources 4: 1-24.

Greene, A.M. 2005. A time constant for hemispheric glacier mass balance. Journal of Glaciology 51 (174): 353-362.

Hargreaves, G.H., and Samani, Z.A.1982. Estimating potential evapotranspiration. Journal of the Irrigation and Drainage Division 108 (3): 225-230.

Henoch, W.E.S. 1971. Estimate of glaciers secular (1948-1966) volumetric change and its contribution to the discharge in the upper North Saskatchewan River Basin. Journal of Hydrology 12: 145-160. 
Hobson, G.D. and C. Jobin. 1975. A seismic investigation-Peyto Glacier, Banff National Park and Woolsey Glacier, Mount Revelstoke National Park. Geo Exploration 13: 117-127.

Hock, R. 1999. A distributed temperature-index ice- and snowmelt model including potential direct solar radiation. Journal of Glaciology 45 (149): 101-111.

Hock, R. 2003. Temperature index melt modelling in mountain areas. Journal of Hydrology 282: 104-115.

Hock, R. 2005. Glacier melt: a review of processes and their modeling. Progress in Physical Geography 29 (3): 362-391.

Hock, R. and Jansson, P. 2005. Modelling Glacier Hydrology. In: Anderson, M.G. and McDonnell, J. (Eds.). Encylopedia of Hydrological Sciences, John Wiley and Sons, Ltd, Chichester; 2647-2655.

Hock, R., Rees, G., Williams, M.W. and Ramirez E. 2006. Preface: Contribution from glaciers and snow cover to runoff from mountains in different climates. Hydrological Processes 20: 2089-2090.

Hodge, S.M., Trabant, D.C., Krimmel, R.M., Heinrichs, T.A., March, R.S. and Josberger, E.G. 1998. Climate variations and changes in mass of three glaciers in western North America. Journal of Climate 11 (2): 161-179. 
Holdsworth, G., Power, J. and Christie, R.O. 1983. Radar ice thickness measurements on Peyto Glacier. National Hydrology Research Institute internal report, Environment Canada, Calgary.

Holdsworth, G.T., Beck, M.H. and Demuth.M.N. 2006. Radar measurements of ice thickness on Peyto Glacier, Alberta - Geophysical and Climatic Implications. In - Peyto Glacier: One Century of Science, Demuth, M.N., Munro, D.S. and Young, G.J. (eds.). National Hydrology Research Institute Science Report 8:59-79.

Hook, R. and Jeeves, T.A 1961. "Direct Search" Solution of Numerical and Statistical Problems, Journal of the Association of Computing Machinery 8: 212.

Hooke, R.LeB. 2005. Principals of Glacier Mechanics. $2^{\text {nd }}$ Edition. Cambridge University Press, Cambridge, UK.

Hopkinson, C. and Demuth, M.N. 2006 Using airborne lidar to assess the influence of glacier downwasting on water resources in the Canadian Rocky Mountains. Canadian Journal of Remote Sensing 32 (2): 212-222.

Hopkinson, C. and English, M. 2001. Spatio-Temporal Variations of $\delta 180$ Isotope Signatures of Hydrological Components Within a Glacierised Mountainous Basin. Proceedings of the 58th Eastern Snow Conference. Ottawa, Ontario, Canada. May 14 - 18. 
Hopkinson, C. and Young, G.J. 1998. The effect of glacier wastage on the flow of the Bow River at Banff, Alberta, 1951 to 1993. Hydrological Processes 12: 1745-1762.

Horton, P., Schaefli, B., Abdelkader, M., Hingray, B. and Musy, A. 2006. Assessment of climate-change impacts on alpine discharge regimes with climate model uncertainty. Hydrological Processes 20: 2091-2109.

Hunt, C.W., Hawryluk, R. and Hildebrandt, D. 1997. Bull trout status in Alberta's Fish Management Area four. Pages 171-186 in Mackay, W.C., Brewin, M.K. and Monita, M. (eds.) Friends of the Bull Trout Conference Proceedings. Bull Trout Task Force (Alberta), c/o Trout Unlimited Canada, Calgary.

Intergovernmental Panel on Climate Change (IPCC). 2007. Climate Change 2007: The Physical Science Basis. Contribution of Working Group I to the Fourth Assessment Report of the Intergovernmental Panel on Climate Change. Solomon, S., Qin, D., Manning, M., Chen, Z., Marquis, M., Averyt, K.B., Tignor, M. and Miller, H.L. (eds.). Cambridge University Press, Cambridge, United Kingdom and New York, NY, USA.

Jóhannesson, T., Raymond, C.F. and Waddington, E.D. 1989. Time-scale for adjustment of glaciers to changes in mass balance. Journal of Glaciology 35: 355-369. 
Jóhannesson, T., Sigurðsson, O. Laumann, T. and Kennett.M. 1995. Degree-day mass balance modelling with applications to glaciers in Iceland, Norway and Greenland. Journal of Glaciology 41(138): 345-358.

Kargel, J.S., Abrams, M.J., Bishop, M.P., Bush, A., Hamilton, G., Jiskoot, H., Kaab, A., Kieffer, H.H., Lee, E.M., Paul, F., Rau, F., Raup, B., Shroder, J.F., Soltesz, D., Stainforth, D., Stearns, L. and Wessels, R. 2005. Multispectral imaging contributions to global land ice measurements from space. Remote sensing of environment 99 (1-2): 187-219.

Kuhn, M. 1993. Possible future contributions to sea level change from small glaciers. In Climate and Sea Level Change: Observations, Projections and Implications, Warrick, R.A., Barrow, E.M. and Wigley, T.M.L. (eds.) Cambridge University Press 134-143.

Klok, E.J. and Oerlemans, J. 2004. Climate Reconstructions Derived from Global Glacier Length Records. Arctic, Antarctic, and Alpine Research 36 (4): 575-583.

Kouwen, N. 1988. WATFLOOD: a micro-computer based flood forecasting system based on real-time weather radar. Canadian Water Resources Journal 13 (1): 62-77.

Kouwen, N. 2006. WATFLOOD/WATROUTE Hydrological Model Routing and Flow Forcasting System, Since 1972. Users Manual. Available at www.watflood.ca 
Kouwen, N., Soulis, E.D., Pietroniro, A., Donald, J. and Harrington, R.A. 1993. Grouped response units for distributed hydrologic modelling. Journal of Water Resources Planning and Management, ASCE 119(3): 289-305.

Krimmel, R.M. and Tangborn, W.V. 1974. South Cascade Glacier: The Moderating Effect of Glaciers on Runoff. Proceedings of the Western Snow Conference, 42nd Annual Meeting, Anchorage, Alaska, 9-13.

Labat, D., Godderis, Y., Probst, J.L. and Guyot, J.L. 2004. Evidence for global runoff increase related to climate warming. Advances in Water Resources 27: 631-642.

Lafrenière, M. and Sharp, M. 2003. Wavelet analysis of inter-annual variability in the runoff regimes of glacial and nival stream catchments, Bow Lake, Alberta. Hydrological Processes 17: 1093-1118.

Laumann, T. and Reeh, N. 1993. Sensitivity to climate change of the mass balance of glaciers in southern Norway. Journal of Glaciology 39 (133): 656-665.

Le Meur, E., Gagliardini, O., Zwinger, T. and Ruokolainen, J. 2004. Glacier flow modelling: a comparison of the Shallow Ice Approximation and the full-Stokes solution. C.R. Physique 5: 709-722. 
Letreguilly, A. 1988. Relation between the mass balance of western Canadian mountain glaciers and meteorological data. Journal of Glaciology 34:116.

Linsley, R.K., Kohler, M.A., and Paulhus, J.L.H. 1949. Applied hydrology, McGraw-Hill, New York.

Loijens, H.S. 1974. Streamflow Formation in the Mistaya River Basin, Rocky Mountians, Canada. Proceedings of the Western Snow Conference, 42nd Annual Meeting, Anchorage, Alaska, 86-95.

Loukas, A., Vasiliades, L. and Dalezios, N.R. 2002. Climatic impacts on the runoff generation processes in British Columbia, Canada. Hydrology and Earth System Sciences 6 (2): 211-227.

Luckman, B.H. 1998. Landscape and climate change in the central Canadian Rockies during the $20^{\text {th }}$ century. Canadian Geographer 42 (4): 319.

Luckman, B.H., Holdsworth.G. and Osborn. G.D. 1993. Neoglacial glacier fluctuation in the Canadian Rockies. Quaternary Research 39: 144-153.

Luo, W. 1998. Hypsometric analysis with a geographic information system. Computers and Geosciences 24 (8): 815-821. 
Mark, B.G. and Seltzer, G.O. 2003. Tropical glacier meltwater contribution to stream discharge: a case study in the Cordillera Blanca, Peru. Journal of Glaciology 49 (165): 271-281.

Martin, F.R.J. 2002. Gross evaporation for the 30-year period 1971-2000 in the Canadian Prairies. Hydrology Report \#143, Agriculture and Agri-Food Canada. Prairie Farm Rehabilitation Administration, Regina, Saskatchewan.

Marshall, S.J. 2006. Modelling glacier response to climate change. In: Glacier Science and Environmental Change. Knight, P.G. (ed.) Blackwell Publishing Ltd, Oxford, UK.

Marshall, S.J. and Clarke, G.K.C. 1999. Modeling North American Freshwater Runoff through the Last Glacial Cycle. Quaternary Research 52: 300-315.

McCabe, G.J., Fountain, A.G. and Dyurgerov, M. 2000. Variability in winter mass balance of Northern Hemisphere glaciers and relations with atmospheric circulation. Arctic Antarctic and Alpine research 32 (1): 64-72.

Meier, M.F. 1969. Glaciers and water supply. Journal of the American Water Works Association 61(1):8-12.

Meier, M.F. 1973. Hydraulics and hydrology of glaciers. IAHS, Publication No. 107: 353-370. 
Meier, M.F., Dyurgerov, M.B. and McCabe, G.J. 2003. The Health of Glaciers: Recent Changes in Glacier Regime. Climatic Change 59: 123-135.

Meier MF, Tangborn WV. 1961. Distinctive characteristics of glacier runoff. USGS Prof. Pap. 424 (B):14-16.

Meyer, J.L., Sale, M.J., Mulholland, P.J.and Poff, N.L. 1999.Impacts of climate change on aquatic ecosystem functioning and health. Journal of the American Water Resources Association 35: 1373-1386.

Moore, R.D. 1992. The influence of glacier cover on the variability of annual runoff, Coast Mountains, British Columbia, Canada. Canadian Water Resources Journal 17: 101-109.

Moore, R.D. 1999. Application of a conceptual streamflow model in a glacierised drainage basin. Journal of Hydrology 150: 151-168.

Moore, R.D. and Demuth, M.N. 2001. Mass balance and streamflow variability at Place Glacier, Canada, in relation to recent climate fluctuations. Hydrological Processes 15: 3473-3486.

Morris, M.D. 1991 Factorial Sampling Plans for Preliminary Computational Experiments. Technometrics 33: 161-174. 
Morris, E.M. 2006. Techniques for Predicting Runoff from Glacierised Areas. In - Peyto Glacier: One Century of Science, Demuth, M.N., Munro, D.S. and Young, G.J. (eds.). National Hydrology Research Institute Science Report 8: 59-79.

Munro, S. 1977. An experimental study of the glacier boundary layer over melting ice. Journal of Glaciology 18: 80.

Munro, S. 2005. A revised Canadian perspective: progress in glacier hydrology. Hydrological Processes 19: 231-245.

Munro, S. 2006. Linking the Weather to Glacier Hydrology and Mass Balance at Peyto Glacier. In - Peyto Glacier: One Century of Science, Demuth, M.N., Munro, D.S. and Young, G.J. (eds.). National Hydrology Research Institute Science Report 8: 59-79.

Neff, B.P. and Nicholas, J.R. 2005. Uncertainty in the Great Lakes Water Balance: U.S. Geological Survey Scientific Investigations Report 2004-5100, 42 p.

Napleralski, J., Li, Y.K. and Harbor, J. 2006. Comparing predicted and observed spatial boundaries of geologic phenomena: Automated Proximity and Conformity Analysis applied to ice sheet reconstructions. Computers and Geoscicenes 32 (1): 124-134.

Nash, J.E. and Sutcliffe, J.V. 1970. River Flow Forecasting through Conceptual Models; Part IA discussion of Principles. Journal of Hydrology 10 (3): 282-290. 
Oerlemans, J., Anderson, B., Hubbard, A., Huybrechts, P.H., Jóhannesson, T., Knap, W.H., Schmeits, M., Stroeven, A.P., van de Wal, R.S.W., Wallinga, J. and Zuo, Z. 1998. Modelling the response of glaciers to climate warming. Climate Dynamics 14: 267-274.

Ohmura, A. 2000. Physical Basis for the Temperature-Based Melt-Index Method. Journal of Applied Meteorology 40 (4): 753-761.

Ostrem, G. 2006. History of Scientific Studies at Peyto Glacier. In - Peyto Glacier: One Century of Science, Demuth, M.N., Munro, D.S. and Young, G.J. (eds.). National Hydrology Research Institute Science Report 8: 59-79.

Paul, F., Kaab, A., Maisch, M., Kellenberger, T. and Haeberli, W. 2004. Rapid disintegration of Alpine glaciers observed with satellite data. Geophysical Research Letters 31 : 21 No. L21402.

Philip, J. R. 1954. An infiltration equation with physical significance. Soil Science 77 (1) 153157.

Pietroniro, A., Demuth, M.N., Comeau, L.E.L., Hopkinson, C., Dornes, P., Kouwen, N., Brua, B., Toyra, J. and Bingeman, A. (internal report). Streamflow shifts resulting from past and future glacier fluctuations in the eastern flowing basins of the Rocky Mountains. For the Climate Change Resources Users Group, Government of Alberta and Alberta Environment. National Hydrology Research Centre. 202pp + CD- ROM. Contact Al Pietroniro at the National Hydrology Research Centre, Saskatoon, Saskatchewan. 
Pike, R.J. and Wilson, S.E. 1971. Elevation-relief ratio, hypsometric integral and geomorphic area-altitude analysis. Geological Society of America Bulletin 82: 1079-1084.

Pomeroy, J.W., Gray, D.M., Brown, T., Hedstrom, N.R., Quinton, W.L., Granger, R.J. and Carey, S.K. 2007. The cold regions hydrological model: a platform for basing process representation and model structure on physical evidence. Hydrological Processes 21: 2650-2667.

Power, J.M. 1985. Canada case study - Water supply. In Young, G.J. (ed.), Techniques for prediction of runoff from glacierized areas: International Association of Hydrological Sciences Publication No. 149: 59-71.

Priestley, C.H.B. and Taylor, R.J. 1972. On the assessment of surface heat flux and evaporation using large-scale parameters. Mon. Weather Rev. 100 (2): 81-92.

Radić, V. and Hock, R. 2006. Modeling future glacier mass balance and volume changes using ERA-40 reanalysis and climate models: A sensitivity study at Storglaciären, Sweden. Journal of Geophysical Research 111 F03003.

Rasmussen, L.A. and Conway, H. 2004. Climate and glacier variability in western North America. Journal of Climate 17 (9): 1804-1815.

Rees, H.G. and Collins, D.N. 2006. Regional differences in response of flow in glacier-fed Himalayan rivers to climatic warming. Hydrological Processes 20 (10): 2157-2169. 
Refsgaard, J.C. and Storm, B. 1996. Construction, calibration and validation of hydrological models, In Distributed Hydrological Modelling, Abbott, M.B. and Refsgaard, J.C. (eds.), Kluwer Academic Publishers, 41-54.

Richards, K.S., Sharp, M.J., Arnold, N., Gurnell, A.M., Clarke, M.J., Tranter, M., Nienow, P.W., Brown, G.H., Willis, I.C. and Lawson, W.J. 1996. An integrated approach to modelling hydrology and water quality in glacierized catchments. Hydrological Processes 10: 479-508.

Rood, S.B., Pan, J., Gill, K.M., Frankcs, C.G., Samuelson, G.M. and Shepherd, A. 2008. Declining summer flows of Rocky Mountain rivers: Changing seasonal hydrology and probable impacts on floodplain forests. Journal of Hydrology 349 (3-4): 397-410.

Roy, J.W. and Hayashi, M. 2008. Groundwater exchange with two small alpine lakes in the Canadian Rockies. Hydrological Processes 22: 2838-2846.

Schiefer, E., Menounos, B. and Wheate, R. 2007. Recent volume loss of British Columbian glaciers, Canada. Geophysical Research Letters 34 L16503.

Schuster, C.J. and Young.G.J. 2006. The derivation of runoff from the Peyto Glacier catchment. In - Peyto Glacier: One Century of Science, Demuth, M.N., Munro, D.S. and Young, G.J. (eds.).National Hydrology Research Institute Science Report 8 :223-248. 
Sharp, M., Copland, L., Filbert, K., Burgess, D. and Williamson, S. 2003. Recent changes in the extent and volume of Canadian Arctic glaciers. In Casey, A., (ed.) Papers and recommendations: Snow Watch 2002 Workshop and Assessing Global Glacier Recession. Boulder, CO, National Snow and Ice Data Center/ World Center for Glaciology, 70-72. (Glaciological Data Report GD32.)

Shea, J.M. and Marshall, S.J. 2007. Atmospheric flow indices, regional climate, and glacier mass balance in the Canadian Rocky Mountains. International Journal of Climatology 27: 233-247.

Shea, J.M. and Moore, R.D. 2007. Estimation of meteorological inputs for regional modeling of glacier melt. Eco Trans. AGU 88 (52), Fall Meet. Suppl., Abstract C41A-0059.

Shea, J.M., Marshall, A.J. and Livingston, J.M. 2004. Glacier Distributions and Climate in the Canadian Rockies. Arctic, Antarctic, and Alpine Research 36 (2): 272-279.

Singh, P., Arora, M. and Goel, N.K. 2006. Effect of climate change on runoff of a glacierized Himalayan basin. Hydrological Processes 20 (9): 1979-1992.

Singh, P. and Bengtsson, L. 2005. Impact of warmer climate on melt and evaporation for the rainfed, snowfed and glacierfed basins in the Himalayan region. Journal of Hydrology 300: 140154. 
Singh, P., Kumar, N. and Arora, M. 2000. Degree-day factors for snow and ice for the Dokriani Glacier, Garhwal Himalayas. Journal of Hydrology 235 (1-2): 1-11.

Singh, P. and V.P. Singh. 2001. Snow and Glacier Hydrology. Kluwer Academic Publishers, Dordrecht, Netherlands.

Singh, P. and Kumar, N. 1997. Impact assessment of climate change on the hydrological response of a snow and glacier melt runoff dominated Himalayan river. Journal of Hydrology 193: $316-350$.

Skeiker, K. 2006. Correlation of global solar radiation with common geographical and meteorological parameters for Damascus province, Syria. Energy Conservation and Management 47: 331-345.

Small, E.E. 1995. Hypsometric forcing of stagnant ice margins: Pleistocene valley glaciers, San Juan Mountains, Colorado. Geomorphology 14: 109-121.

Sorooshian, S. and Gupta, V.K. 1995. Model Calibration. In: Singh, V.P. (ed.) Computer Models of Watershed Hydrology. Water Resources Publications.

SSRB, 2007. Climate Change and Water - South Saskatchewan River Basin Final Technical Report. Martz,L., Bruneau, J. and Rolfe, J.T. (eds.) Climate Change Impacts and Adaptation Program. 266pp + Appendices. 
Stahl, K. and Moore, R.D. 2006. Influence of watershed glacier coverage on summer streamflow in British Columbia, Canada. Water Resources Research 42: W06201.

Stahl, K., Moore, R.D. and McKendry, I.G. 2006. The role of synoptic-scale circulation in the linkage between large-scale ocean-atmosphere indices and winter surface climate in British Columbia, Canada. International Journal of Climatology 26: 541-560.

Stahl, K., Moore, R.D., Shea, J.M., Hutchinson, D. and Cannon, A.J. 2008. Coupled modelling of glacier and streamflow response to future climate scenarios. Water Resources Research 44: WO2422.

Strahler, A.N. 1952. Hypsometric (area-altitude) analysis of erosional topography. Geological Society of America Bulletin 63: 1117-1141.

Tangborn, W. 1999. A mass balance model that uses low altitude meteorological observations and the area-altitude distribution of a glacier. Geografiska Annaler. Series A. Physical Geography 81A (4): 753-765.

Tangborn, W.V., Krimmel. R.M. and Meier, M.F. 1975. A comparison of glacier mass balance by glaciological, hydrological and mapping methods, South Cascade glacier, Washington. Snow and Ice- Symposium, No 104. 
Taylor, K.E. 2001. Summarizing multiple aspects of model performance in a single diagram. Journal of Geophysical Resources 106 (D7): 7183-7192.

Tolson, B.A., and Shoemaker, C.A. 2007. Dynamically dimensioned search algorithm for computationally efficient watershed model calibration. Water Resources Research 43: W01413.

Töyrä, J., Pietroniro, A. and Bonsal, B. 2005. Evaluation of GCM simulated climate over the Canadian Prairie Provinces. Canadian Water Resources Journal 30 (3): 245-262.

Trans-Alta Utilities (2006)

http://www.transalta.com/transalta/webcms.nsf/AllDoc/A5FAA9C26A2E1153872571A80002E8 BC?OpenDocument. Accessed August 2008.

Vincent, C. and Vallon, M. 1997. Meteorological controls on glacier mass balance : empirical relations suggested by measurements on glacier de Sarennes, France. Journal of Glaciology 43 (143): 131-137.

Wallace, A.L. 1995. The volumetric change of the Peyto Glacier, Alberta, Canada 1896-1966. Unpublished Masters Thesis, Wilfrid Laurier University, Canada.

Watson, E., Luckman, B.H. and Yu, Bin. 2006. Long-term relationships between reconstructed seasonal mass balance at Peyto Glacier, Canada, and Pacific sea surface temperatures. The Holocene 16 (6): 783-790. 
Woo, M.K. and Fitzharris, B.B. 1992. Reconstruction of Mass Balance Variations for Franz Josef Glacier, New Zealand, 1913 to 1989. Arctic and Alpine Research 24 (4): 281-290.

Woo, M. and Thorne, R. 2006. Snowmelt contribution to discharge from a large mountainous catchment in subarctic Canada. Hydrological Processes 20: 2129-2139.

Woo, M.K. and Thorne, R. 2003. Streamflow in the Mackenzie Basin, Canada. Arctic 56 (4): $328-340$.

de Woul, M., Hock, R., Braun, M., Thorsteinsson, T., Jóhannesson, T. and Halldorsdottir, S. 2006. Firn layer impact on glacial runoff: a case study at Hofsjoekull, Iceland. Hydrological Processes 20 (10): 2171-2185.

Young, G. 1981. The Mass Balance of Peyto Glacier, Alberta, Canada, 1965 to 1978. Artic and Alpine Research 13 (3): 307-318.

Young, G.J. 1982. Hydrological relationships in a glacierised mountain basin. Hydrological Aspects of Alpine and High Mountain Areas. (Proceedings of the Exeter Symposium, July 1982.) IAHS Publication No.138.

Young, G.J. 1985. Overview - Techniques for prediction of runoff from glacierized areas (Young, G.J. ed.). International Association of Hydrological Sciences Publication 149. 
Young, G.J. 1991. Hydrological interactions in the Mistaya basin, Alberta, Canada. Snow, Hydrology and Forests in High Alpine Areas (Proceedings of the Vienna Symposium, August). No 205 .

Young, G.J. 1995. Contribution of Glacier Melt Water to the flow of the Bow River. Phase 1, Part D. Compilations of data and analysis of trends to the present. To Government of the Province of the Alberta, Department of Environmental Protection.

Young, G.J. and Ommanney, C.S.L. 1984. Canadian glacier hydrology and mass balance studies; a history of accomplishments and recommendations for future work. Geografiska Annaler. Series A. Physical Geography, 66A (3): 169-182.

Yue, S., Pilon, P.J., Phinney, B. and Cavadias, G. 2002. The influence of autocorrelation on the ability to detect trend in hydrological series, Hydrological Processes 16 (9): 1807-1829. 


\section{APPENDIX A}

Observed-simulated graphs modelled by WATFLOOD used for the model efficiency $\mathrm{R}^{2}$ NashSutcliffe evaluation and Mean Bias Difference.

NSRB Headwater Basins
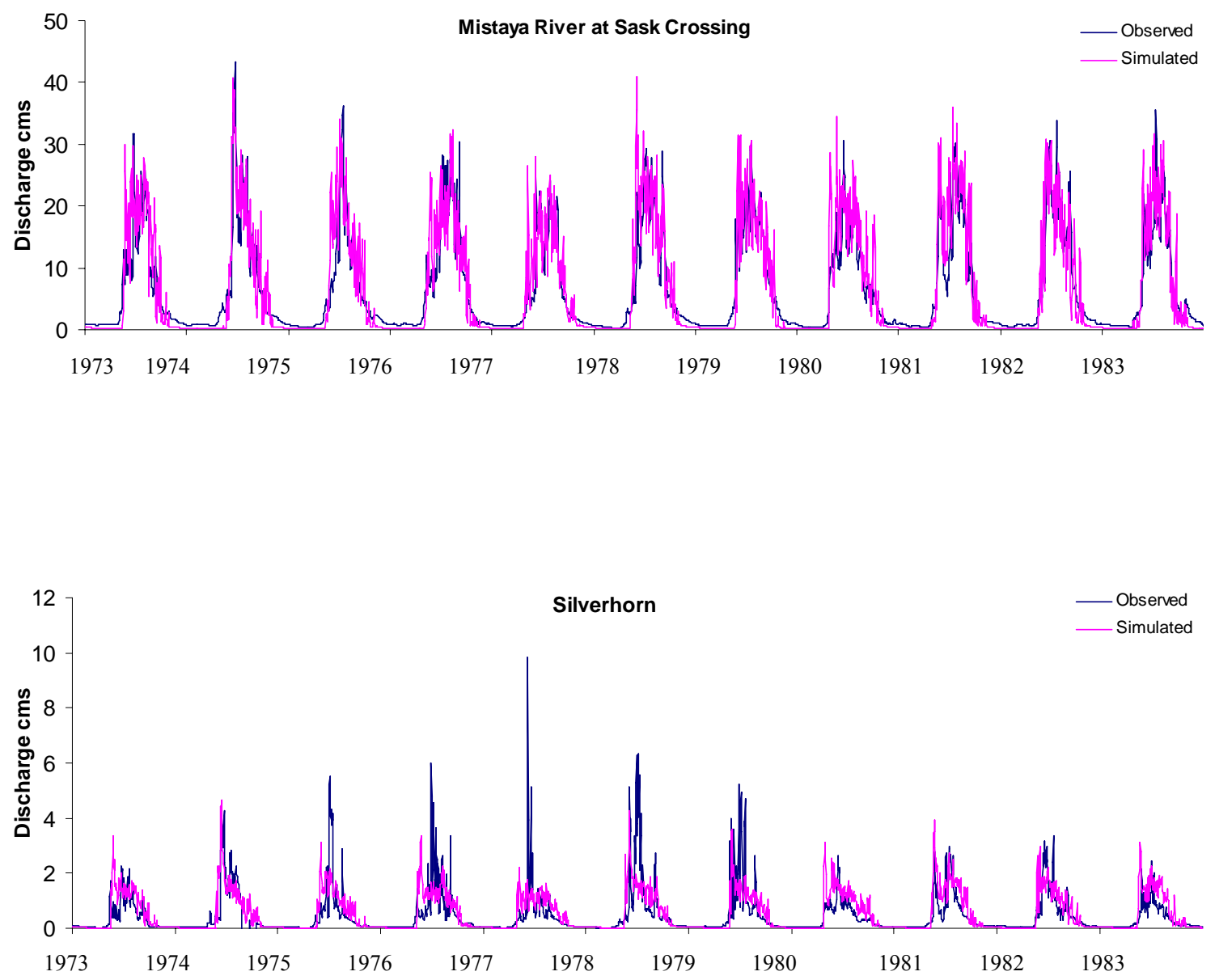

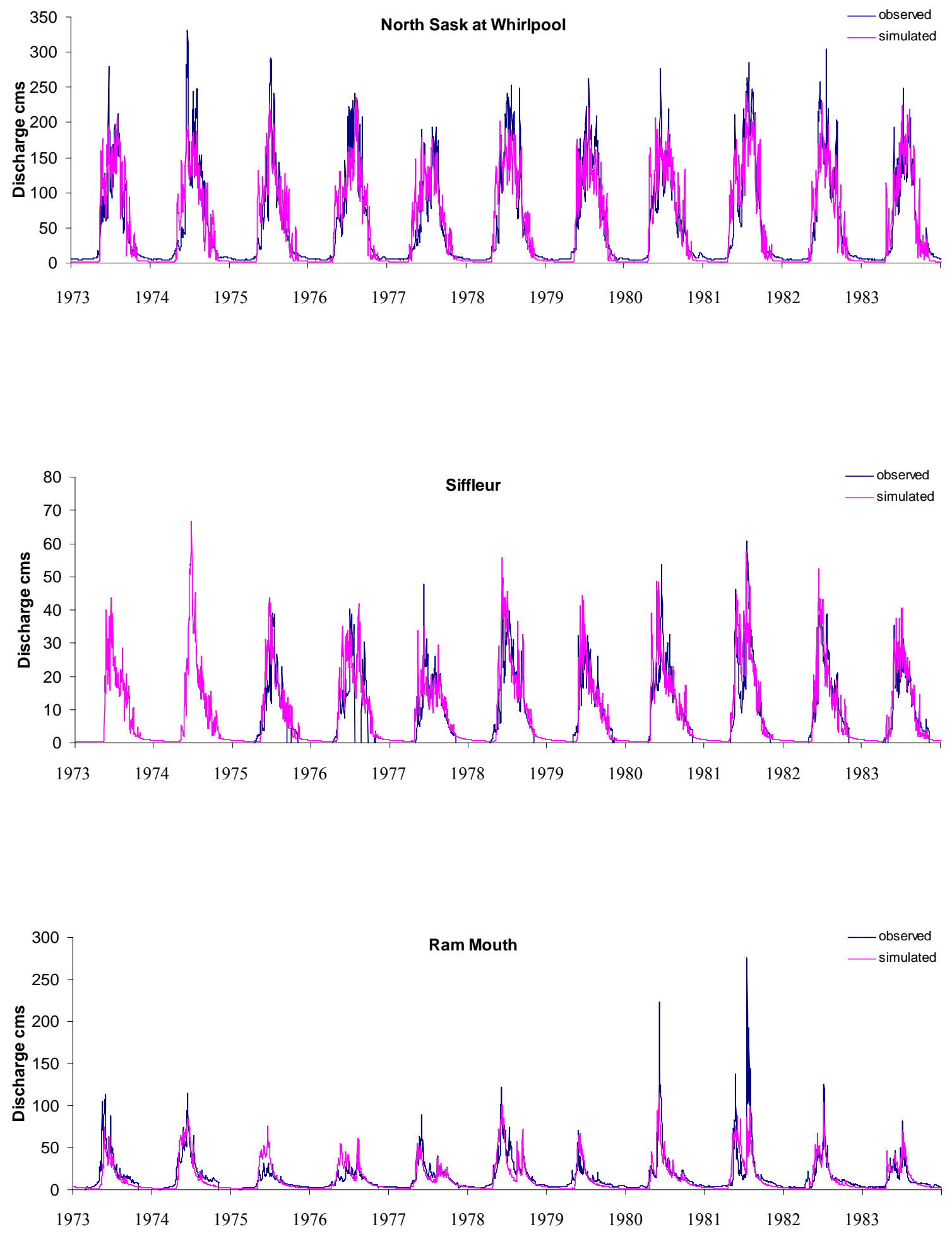


\section{SSRB Headwater Basins}
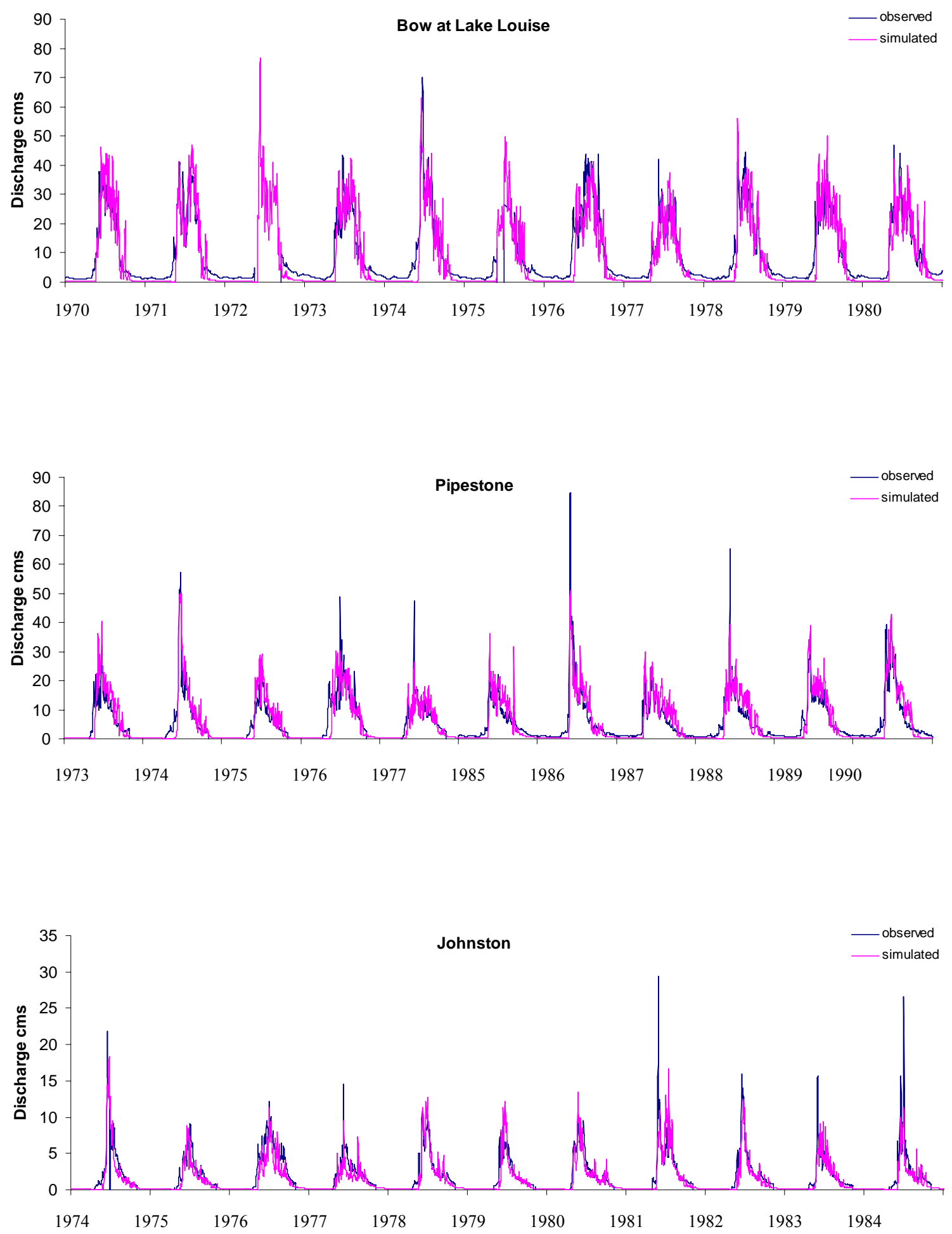

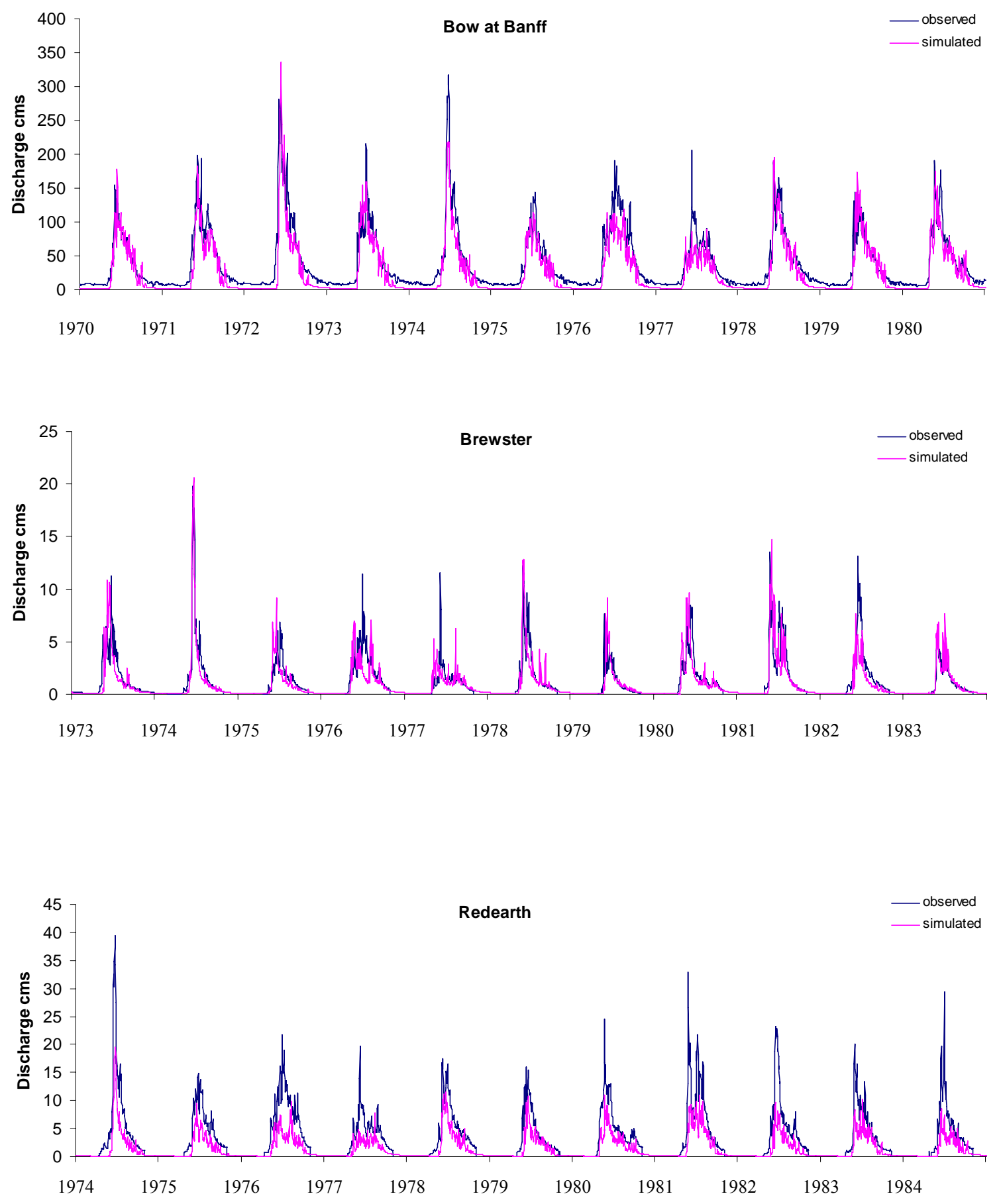

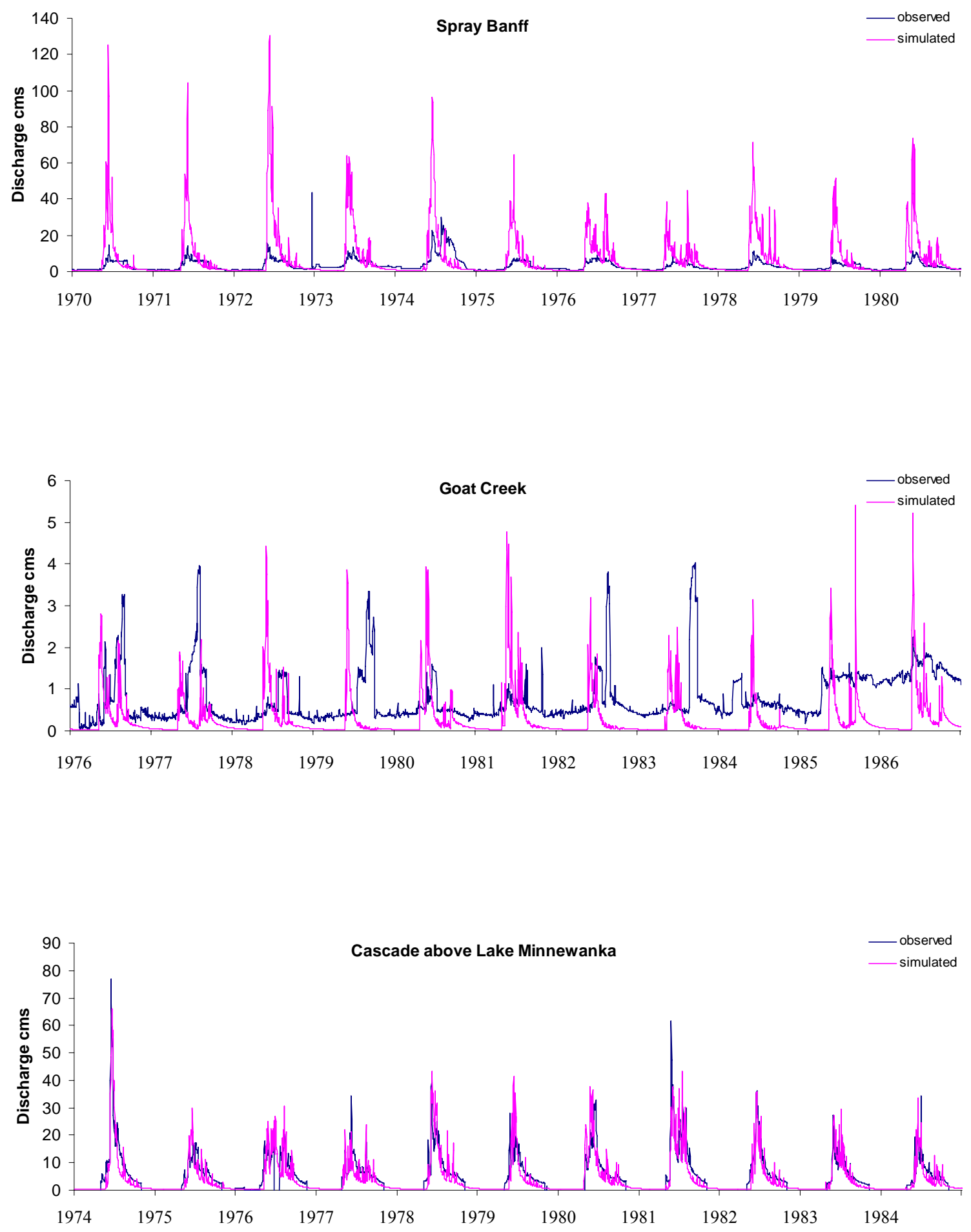


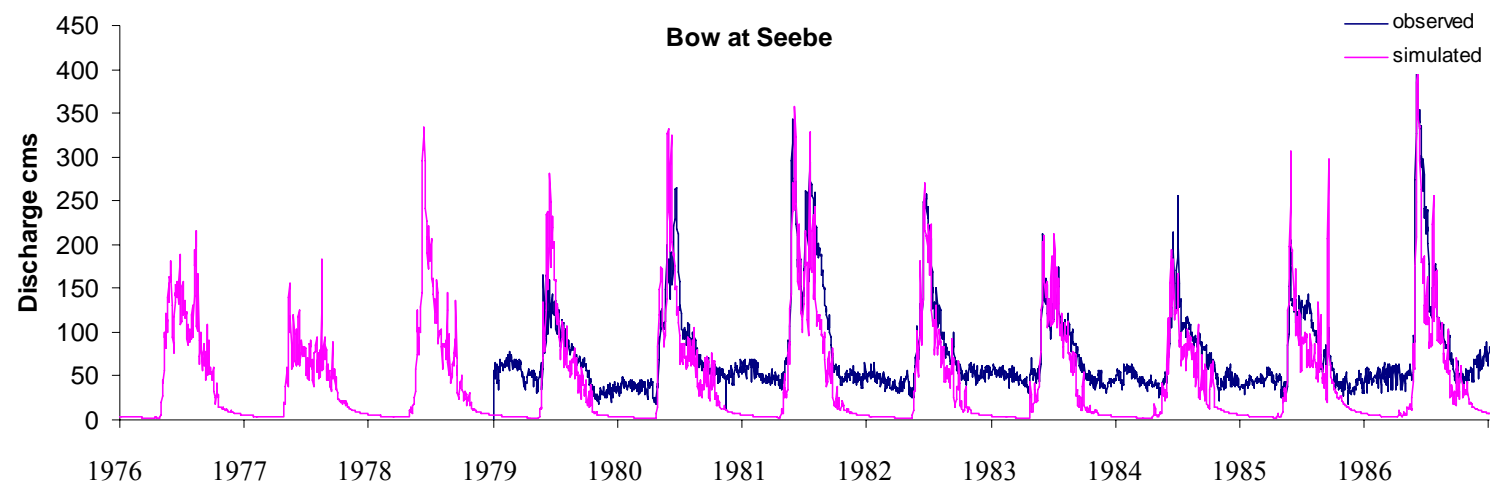




\section{APPENDIX B}

Peyto Glacier Basin Streamflow Output:

September 2007 (glacier fully snow covered) and August 2008 (glacier ablation zone free from snow cover)
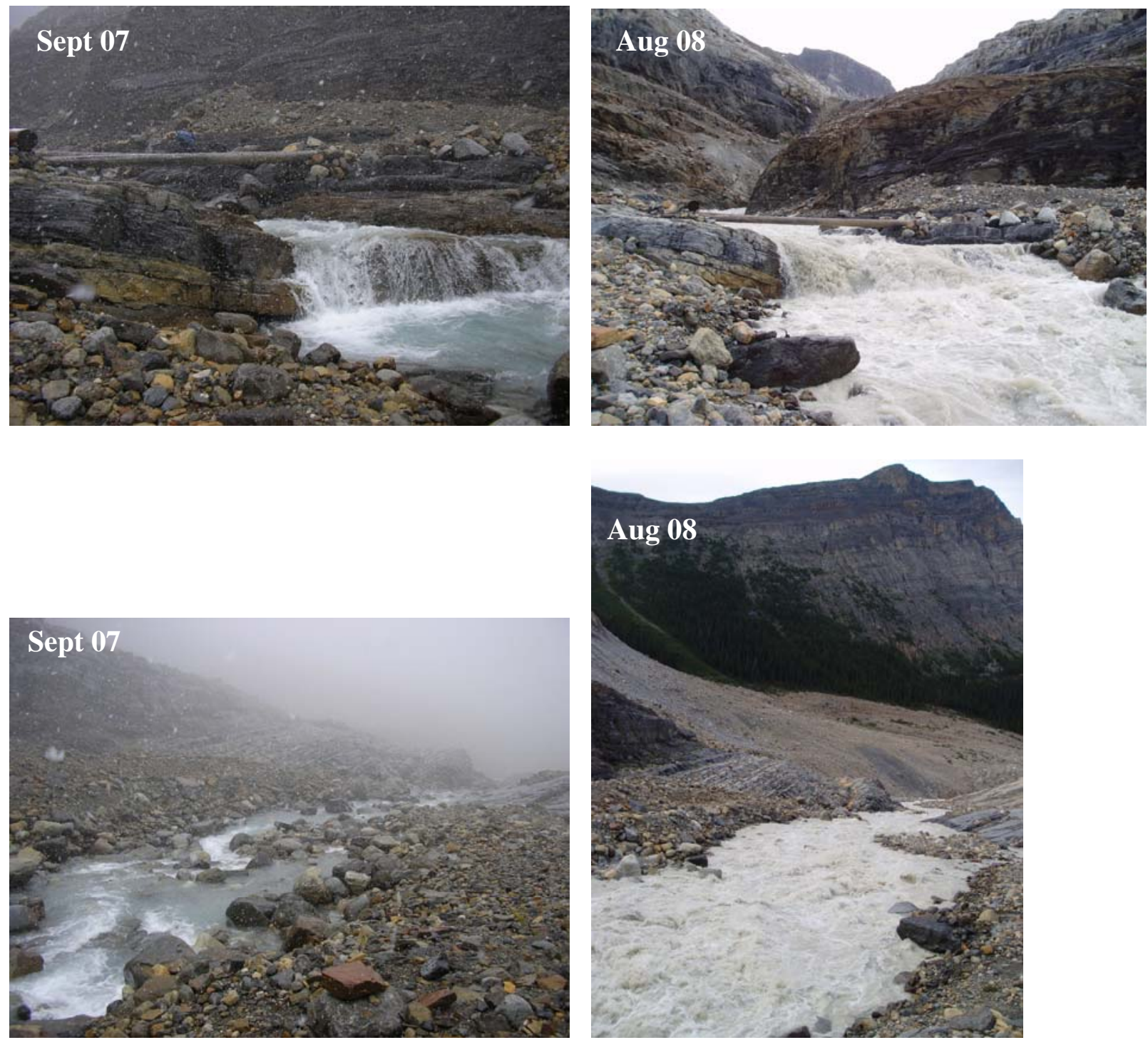


\section{Peyto Glacier Basin:}

Snow covered in September 2007

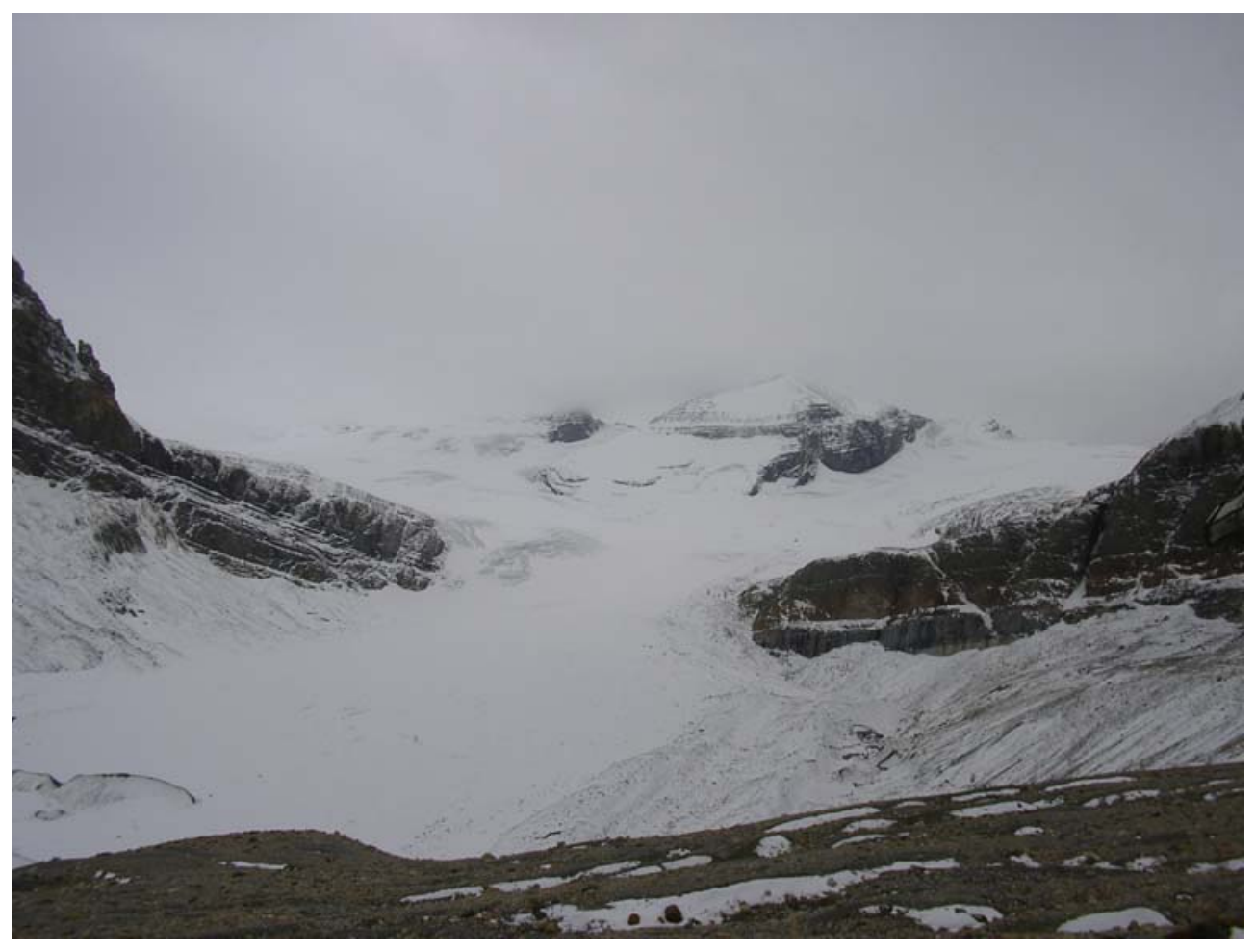

Ablation zone free from snow cover in August 2008

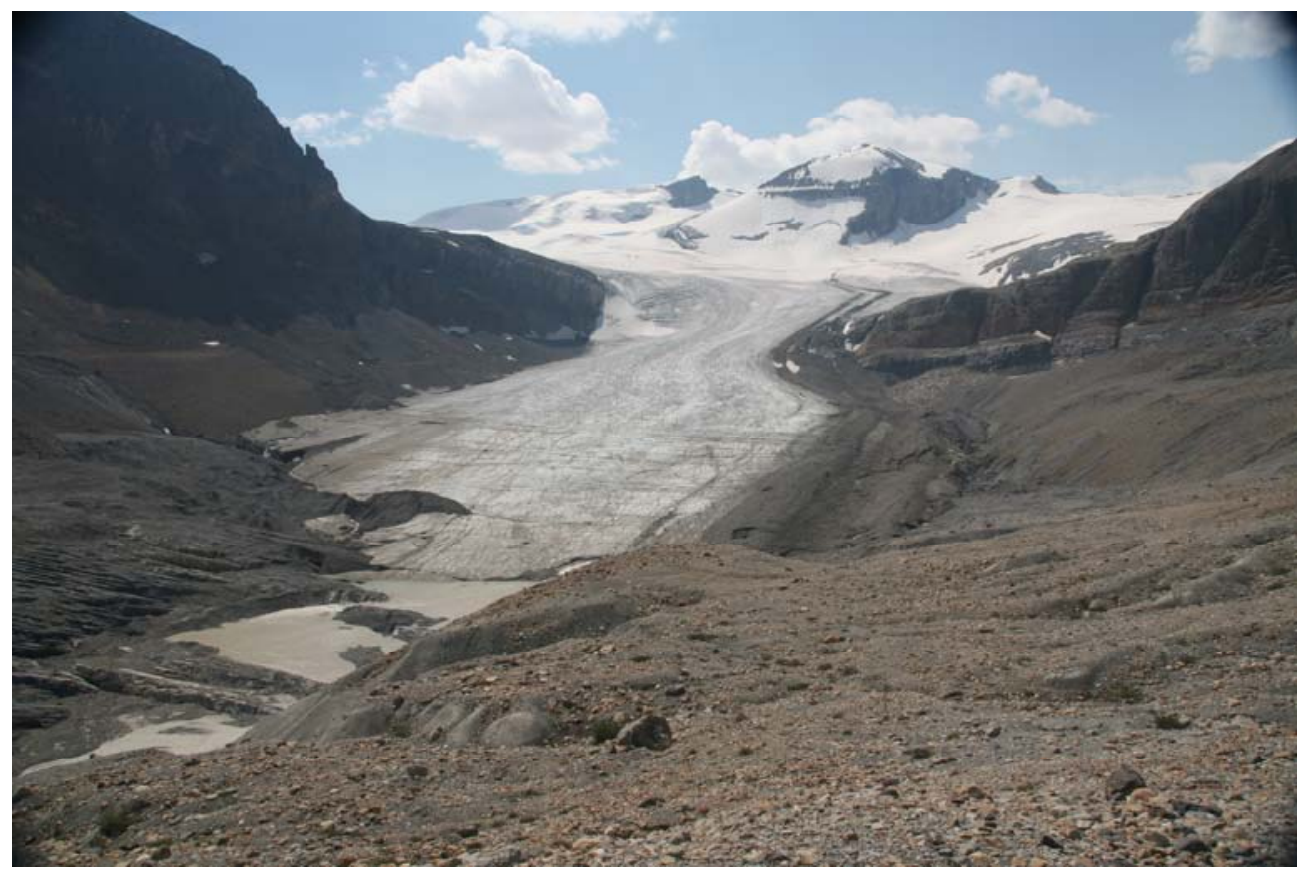

